\title{
MODERN
}

\section{BUTTER MAKING}

LIBRARY

ANNEX
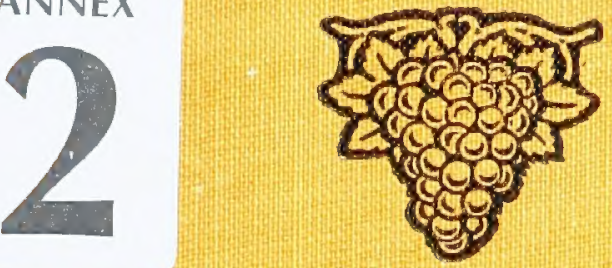

MARTIN H. MEYER 


\section{Cornell University Library}

The original of this book is in the Cornell University Library.

There are no known copyright restrictions in the United States on the use of the text.

http://www.archive.org/details/cu31924003010927 


\section{SF 263.M61 ${ }^{\text {Cornell University Library }}$}

Modern butter making and dairy arithmeti

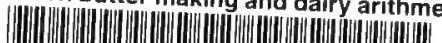






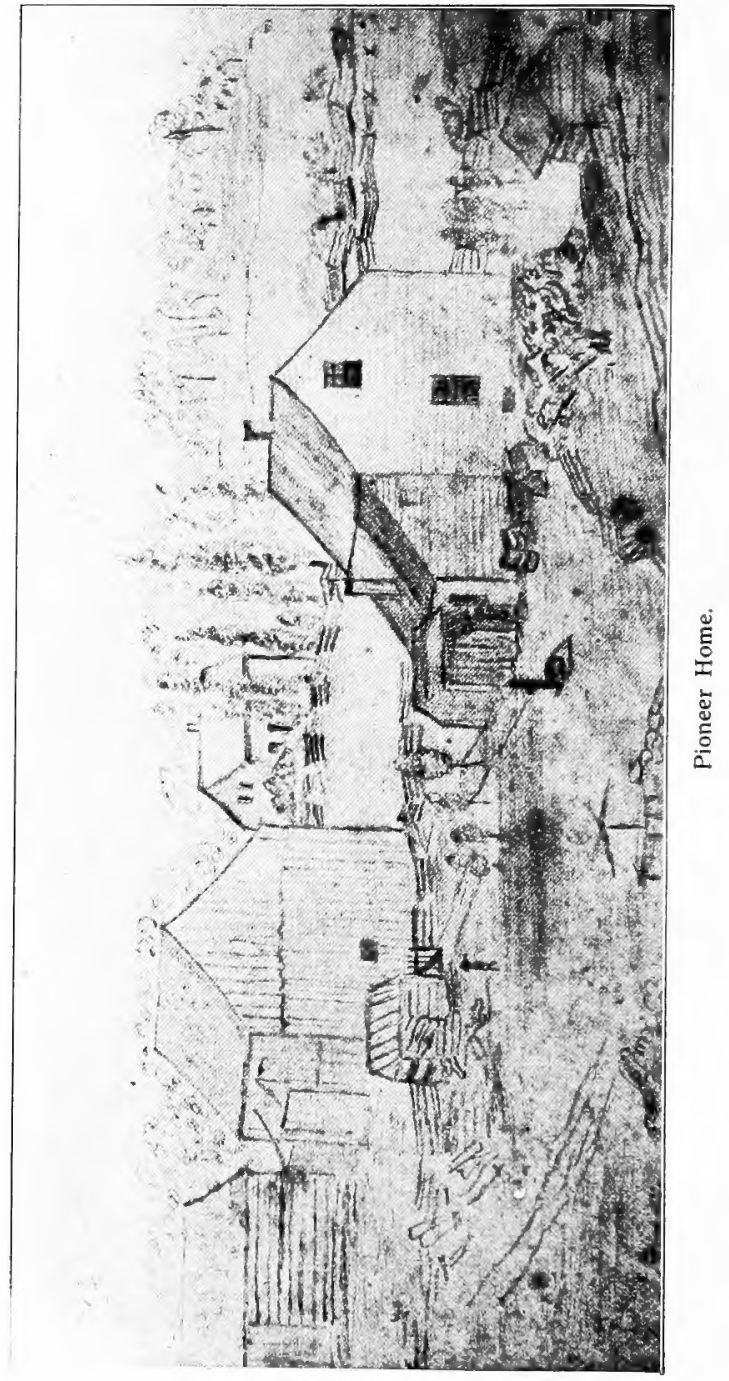




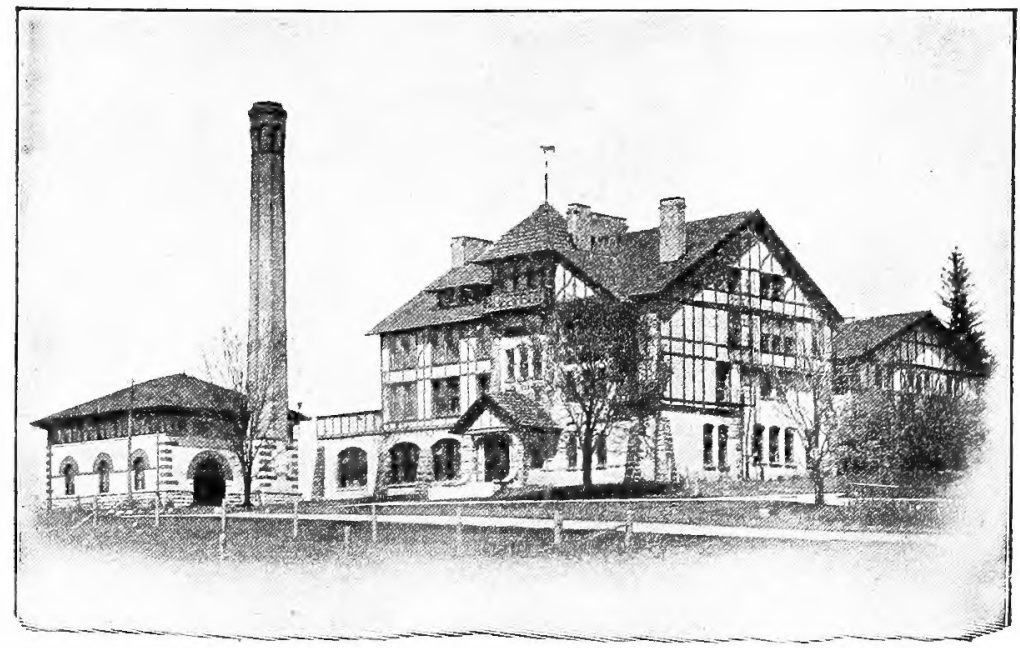

University of Wisconsin Dairy School, Madison, Wisconsin.

My acquaintance with over 2000 dairy students in the past 15 years has convinced me that the three months instruction given each year in the winter dairy course of the Tniversity of Wisconsin is very helpful to the dairy interests of the state. The buttermakers and the cheesemakers find that an inquiry into the reasons for certain operations in their work helps not only to improve the quality of the products they make, but that by using their minds as well as their muscles the work becomes more interesting.

Even a short course in dairying gives many students a start in the right direction and they learn by it to be methodical and systematic in their every day work. They also learn that it is necessary to follow the dairy press and dairy textbooks to keep up with the progress that is made each ycar.

E. H. FARRINGTON. 


\section{Improve Quality of Cream Through Constitution and By-Laws of Creameries.}

A very effective method of assisting in the improving of the quality of cream delivered to creameries is by incorporating into the constitution and by-laws such regulations as may be deemed necessary for the correcting of irregularities in the quality, richness and delivery of cream.

I. Poor Cream. Having "had losses on butter which were directly traceable to a few cans of poor cream, the creamery operator is instructed to reject all bad cream. All cream not first class, yet acceptable is to be graded as "second" and for this is paid five cents less per pound of butter fat than is paid for first class cream.

II. Too Thin Cream. Any patron delivering cream testing less than $25 \%$ butter fat will receive five cents less per pound of butter fat than is paid for first class cream testing as required. This rule to go into effect after the patron has been given due instruction and warning by the ereamery operator.

Late Deliveries of Cream. The creamery operator is instructed to reject cream from patrons who deliver cream later than the time stipulated in the bylaws. If such cream is accepted it is to be paid for at the rate of five cents less than ihe best price paid per pound of butter fat.

Creameries adopting these or similar rules, have found the system to be of great assistance in improving the quality of the cream as well as the service 
in general. Under this system patrons will ask for instruction regarding the care of cream. They are willing that the ereamery operator shall be the judge of their cream for they depend upon him to give them the fancy price that butter made from good crearn always commands.

\section{THE AUTHOR.}

\section{Dairy School the Best Medium.}

Dairying is the highest and most specialized form of agriculture. Its suceess requires men thoroughly trained along broad and many-sided lines, and skillfull in the practical application of their knowledge

The future progress of the dairy industry must. therefore, Iargely depend on the number of thoroughly trained and competent-dairymen. Men sc trained are scarce, their demand far exceeds the supply and their opportunities are as numerous as the pebbles on the beach.

The laying of a broad foundation for this life work and the aequiring of this knowledge and train ing are accomplished most effectively and mos1 rapidly through the medium of our dairy schools.

The dairy school is the factory, the clearing houst and the distributory of dairy information, and it: graduates are the pioneers of modern dairying, the exponents of real dairy progress and development

\section{O. F. HUNZIKER.}




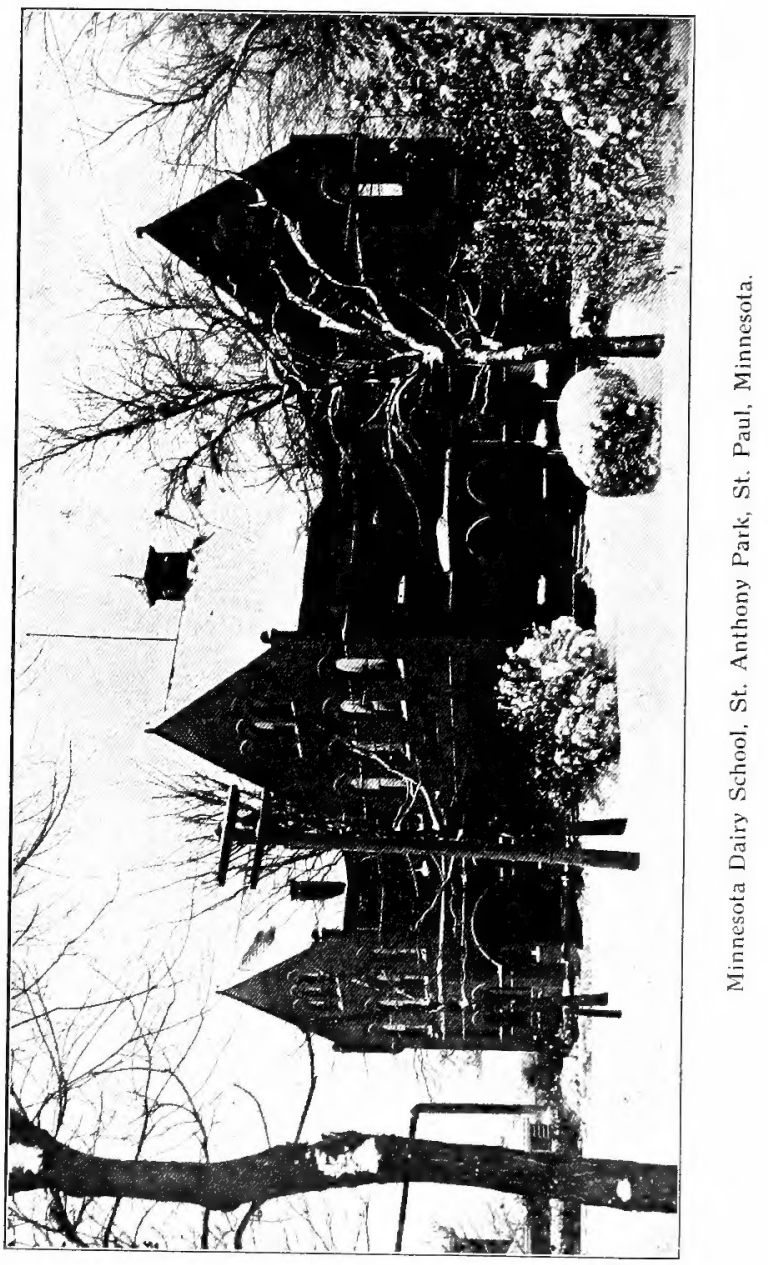


The young man who chooses the occupation of a creamery butter maker must, in order to suceed, thoroly appreciate the necessity of acquiring a scientific knowledge of dairy subjects. The mechanical knowledge necessary in order to operate the machinery in a creamery is of minor importance. altho, of course, very essential. This knowledge can be acquired during the young man's apprenticeship, proriding he is under the tutelage of a good butter maker and one who is not only willing but competent to impart information.

The reason why things should be done in a certain way, or in other words, the scientific principles involved in dairy manufacture can best be learned at a Dairy School where these things are explained in lectures and facilities are provided for demonstration work in the various steps of dairy manufacture.

Young men coming to the dairy school usually have in mind solely the art of making butter or cheese. They soon learn, howerer, that one who is but familiar with this part of the work is only a half-baked dairyman; that the eor, the feed and the care of the herd are really the more important factors in the dairy industry. It broadens their views and they look forward to the time when they can do eren better than making butter or cheese.

$$
\text { T. L. HAECKER. }
$$




\section{Learn the Why and the Wherefore.}

Dairy education is not a goal, it is not the end sought; it is a tool to be used in attaining the desired end, and just as some can not drive a nail without marring the wood or even saw a board straight, so some may never profit by education.

Education is training the eye to see, to read, and the mind to think and draw riglt conclusions from conflicting data and evidence. The seeker after truth asks two men, each of wlom have been successful, "What is the proper thing to do under such circumstances." Their answers are diametrically opposite. It is then only the man who can analyze and figure out why seemingly opposite methods have brought these men success; who can derive from their answers that which will be of help in his condition.

Again, education is not only training, but it is profiting by the experience of others; it is avoiding the experimental period, the cutting and trying and proving a truth that has already been proved and demonstrated many times over. It accepts that which is proved.

The ancients knew that to keep milk sweet it must be cold. Science has shown us why, and the very beginner in the business of dairying can learn what temperature is necessary to serure the keeping of milk, he can learn whether or not he has that temperature and know that given that temperature, the milk received in the right condition will keep. 
Education then is but the tool that enables him to secure this information and profit by it immediately. Our dairy schools seel to teach men what is so, why it is so and how it may be profitably applied to every day business. They seek to give that amount of practice in the actual doing whick clinches in the mind of the student the why and the wherefore. They can not make the dull man more bright or the lazy man more aggressive. They may give added incentive by contact with others, they can give him additional tools for his work: His success in using them depends on his own measure of ability and energy. Few men who are worth education need go long without it. The young man who expects to rise to a position of responsibility and individual independence, who hopes to have his own business as ereameryman, dairyman or in any branch of the great dairy industry can afford to add to his natural endowment and to the practical experience which he has been fortunate enough to acquire, the help which comes with systematic training in high school and college. Whether it be a few wetks, a few months, a year, or a four years course need only be determined by personal. individual circumstances. Aim at what you want, then get as near it as possible.

H. E. VAN NORMAN. 


\section{CARE AND CLEANLINESS IN THE PRODUC- TION OF MILK.}

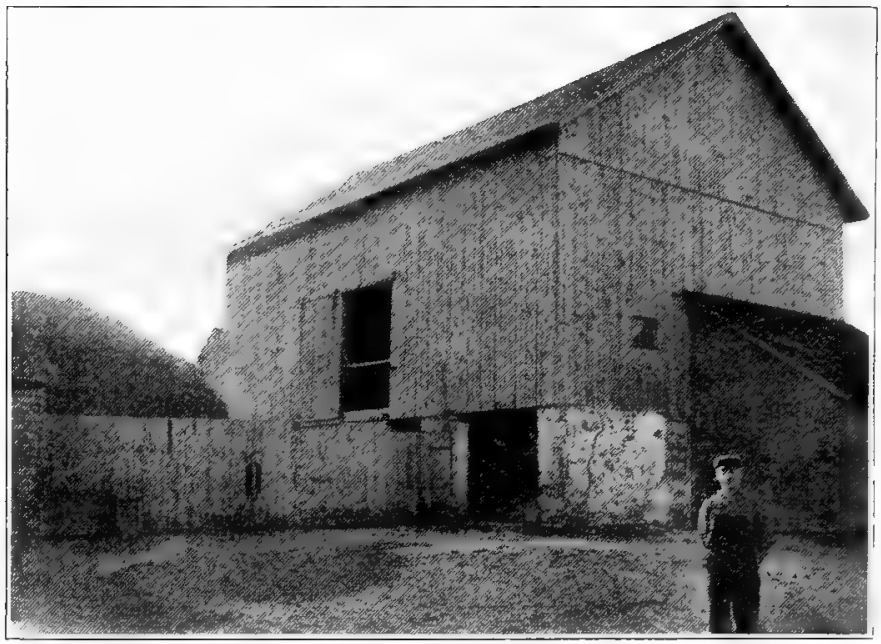

Exterior of a Common Barn.

The official score of this barn is 48.4 per cent. The milk produced in it took first priz" at the International Juiry Show in Milwaulse. Wis., 1912, with a score of $98.3 \%$. It took first prize because the (ows ware kept elean and theje udders wiped before milking. Dlen the milk was oouluel immodiately and lispt cool.

On the other hand milk produced in a model baru whore dotails in care and cluanliness were overlooked scored only $7.3 .5 \%$.

cledu milk can be protucect on any farm. by any one with ordinary intollignes, and with the most simple and common arrangwments it the detail work is looked after at the right time and in the right way. 


\title{
Success the Measure of Knowledge.
}

Knowledge plus practical experience plus determination to get results is the ammunition required for fighting the battle which culminates in success.

Knowledge broadens our comprehension. It is the eye through which we view our day's labor and wherewith our work is changed from drudgery to pleasure.

"Ignorance is the curse of God. Knowledge the wing wherewith we fly to Heaven."

\author{
(Shakespeare.) \\ II. MORTENSEN.
}





\title{
MODERN BUTTER MAKING
}

\author{
AND
}

\section{DAIRY ARITHMETIC}

BY

\section{MARTIN H. MEYER}

Formerly Assistant in Dairying and Instructor in Practical Butter Making at the University of Wisconsin,

Madison, Wisconsin.

\author{
Author of \\ A Treatise on Starters \\ and \\ Modern Dairy Guide \\ to \\ Greater Profits.
}

With Illustrations. Third Edition, Revised ista,

Madison, Wisconsin.

Published by the Author.

1910. 
Copyrighted 1910

By

MARTIN H. MEYER. 


\section{PREFACE.}

Dairying in its rarious phases is undergoing marked changes in the methods employed at dairy farms, creameries and city milk supply establishments. These rapid changes require a knowledge of the latest and most approved methods for handling the work incident to each phase of practical dairying. The demand for trained and well informed men has ereated a desire for knowledge in this line of work. In view of this fact, as well as requests which came to me for information on subjects pertaining to creamery butter-making, city milk supply and calculating dividends I felt impelled to place this little volume, containing the results of my twentyfive years experience both on dairy farms and in creamery butter-making, as well as my experience as instructor in dairying at the University of Wisconsin, before the practical dairyman.

If I should suceeed in helping only a small number of the dairymen of the country to better their. financial condition; if I should succeed in arousing to some extent the interest of the dairying fraternity with regard to the need of cleaner and purer milk, as well as to the need of pasteurizing all milk and cream (even for cheesemaking), I should feel amply repaid for the time and labor spent in the production of this volume. 
References hars been made to other writers on similar subjects whenerer it was thought necessary, in order to impress the reader with the necessity of studying th: works of other students of dairying, and comparing the different results obtained in this line of work.

Thanks are due to Prof. E. H. Farrington, Madison, Wisconsin, Prof. MI. Mortensen, Ames, Iowa, Prof. O. F. Hunziker, Purdue, Indiana, Prof. T. L. Haecker, St. Inthony Park, Minnesota, and Prof. H. E. Tan Norman, State College, Pennsylyania, for furnishing half-tones of their dairy schools as well as valuable contributions.

Great care has been taken in writing and reading the manuscript of this volume, but it is possible that error's have crept in, in spite of all precautions for guarding against them.

Madison, Wisconsin.

September 1, 1910.

\section{IIARTIN H. IIEYER.}

\section{Preface to Second Edition.}

Some additions and changes hare been made in the second edition in order to keep pace with modern dairy advancement.

Fundamental principles as laid down in the first edition have not been changed as they are the foundation upon which rests modern dairy practice.

The latest jdeas pertaining to good creamery practice have been added.

November 1, 1913. 


\section{INTRODUCTION.}

The aim of all of us, regardless of the kind of work in which we are engaged, is to better our financial and social position. In order to realize, at least in part, our ambition. We must spend a large part of the time not actively engaged in earning a living, in study and researeh. By this I mean that wa should spend a few hours every day in reading what other men, who are actively engaged in our own line of work, are doing. We should spend some time in studying out what course is best for carrying out our plans, and for meeting competition. Such a line of thought is necessary for reaping the greatest pleasur' and profit from our work.

Realizing the importance of modern methods in dairying, and the neressity for their adoption by the dairyman and creameryman, this little book has beren written.

The testing of milk and cream is treated in two chapters. (hapter III in Book I treats this subject in a general way, and Chapter $\mathrm{V}$ in Book II discusses it more fully. These two chapters should be read jointly, in order that the reader may not form wrong conclusions as to my point of view.

Recognizing a public sentiment which is in conformity with my views on the pasteurization of milk and cream, one chapter divided into two parts has been devoted to this subject. The reader is re- 
quested to read the works of other men who have made pasteurization a study, in connection with this chapter.

Realizing the need of greater accuracy and training in calculating dividends at creameries as well as performing other mathematical calculations, a few chapters are devoted exclusively to this part of creamery work. The intention is to present to the reader the main principles of decimals and percentage, for, upon these are based all calculations pertaining the dairying.

Decimal places are carried out only as far as was deemed advisable for practical work.

A general table of contents is placed in the front of the book and a paragraph index giving paragraph numbers is placed before each chapter. Numbers found in the paragraphs are reference numbers.

This volume is to be considered only from a practical point of view, and in the subjects treated in it, an effort has been made to handle them in a manner suitable for the every day practical creameryman. 


\section{TABLE OF CONTENTS.}

\section{BOOK I.}

('hajutel'

Page

I. Receiving Milk and Cream.............

II. Strength of Sulphuric Acid............ 1 i

III. 'Testing Milk and Cream............. 1

IV. Acidity Tests $\ldots \ldots \ldots \ldots \ldots \ldots \ldots \ldots \ldots \ldots$

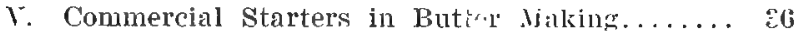

VI. Cream Ripening .................. 70

VII. The Churning of Cream............ 8 .

VIII. 'The Handling of Butter After ('hurning....... 101

IX. Controlling Moisture in Buttel.......... 114

X. Butter Faults .................... 134

XI. The Art of Butter Judging............. 160

XII. (a) Pasteurization ... ............... 170

(b) Pasteurization of Milk and ('leim for ('ity

Supply.................. 182

XIII. Determination of Moisture in Butter........ 199

\section{BOOK II.}

DAIRT ARITIIMETIC.

I. Decimals .................... 215

II. The Overrin $\ldots \ldots \ldots \ldots \ldots \ldots \ldots \ldots \ldots \ldots .23$

III. Standardization of Milk and Cream and Butter Fat' Values ...................250

IV. C'reauly Problems ................ 273

V. Discussion of Cream Tests............ 29! 



\section{BOOK I.}

MODERN BUTTER MAKING. 



\section{CHAPTER I.}

\section{RECEIVING MILK OR CREAM.}

We must not forget that there is a direct relation between the quality of milk and cream when received, and the quality of butter made from it. 


\section{INDEX TO CHAPTER I.}

l'ir. No.

1. A change in the retunel'y system.......... 9

2. Proper intake uresisary .............. 10

$\therefore$ Correct weighiug essential . . . . . . . . . 10

4. I'roper and improper sampling of milk....... 10-11

5. How to sample frozen milk. . . . . . . . . . 11

i. Care of composite milk samples............ 12

7. Preparing composite samples for testing....... 1르.

8. Receiving hand separntor crean............ 1;

9. Concerning composite cream sumples.......... .;-14

10. Concerning sampling cases and tubes.......... 14

11. Cream transportation $\ldots \ldots \ldots \ldots \ldots \ldots \ldots \ldots$. 5

12. Testing each patron's reram while lie waits..... 15

13. Care of composite cream samples............ 16; 


\section{MODERN BUTTER MAKING. BOOK $\mathrm{I}$.}

\section{CHAPTER I.}

\section{Receiving Milk or Cream.}

'The department of a creamery for receiving milk or cream is usually termed the "intake." This is one of the most important departments of a cream. ery and upon the suecessful handling of this department largely depends the success of the creamery.

1. With the advent of the hand separator the intake has in a measure less influence on the patron, but wher' each patron delivers his own milk or cream. the intake exerts a powerful influence for good upon the patrons. The personal influence which the person in charge of this department exerts upon the patrons in furthering the production of clean milk or cream is by no means small. Also the tactful intake man can often adjust matters satisfactorily with a dissatisfied patron, he can often settle financial difficulties by a little careful explanation and in many ways keep things running smoothly. Wherever the patron delivers his milk or cream himself. the right person in charge of the intake can become a real educator among his patrons. A little adrice now and then relative to the production of clean milk is usually well taken and gives good results. When milk or eream is hauled or shipped, this personal 
element influencing the patron is practically lost. At the present time a large part of the milk and cream received at creameries is not delivered by the patron himself and for this reason traveling instructors are not only desirable but absolutely necessary in order to maintain and improve the quality of raw material.

2. Receiving milk. Creamerymen as a rule ar. range the intake to suit their individual conditions and surroundings. One thing which is very necessary is to provide a good protection at the milk receiving place for the comfort of the milk hauler and the weigher or intake man. Patrons of any cream. ery will appreciate the kindness and thoughtfulness of the creameryman in providing such a shelter, especially during cold or rainy weather.

3. The weighing must be accurately done. The scales should be inspected frequently as to their accuracy- Either under or over weight is very detrimental to the success of any creamery. The person who weighs the milk must learn what kind of milk to reject and also how to reject it.

When rejecting poor milk or cream the intake man should be polite but firm in manner. A little judicious reasoning on his part may often avert trouble and cause the patron to leave the creamery satisfied.

4. Sampling milk. Correct sampling is one of the most important factors affecting the results in ereamery work. Sampling should be done immediately after the milk is all poured into the weighing can, but if for any reason this is impossible the milk should be thoroughly mixed before taking the sam. 
ple. It is comparatively easy to correctly sample clean, fresh, whole milk, but if milk is old, or has been partly churned during transportation or is partly frozen or sour or both, correct sampling is difficult.

When milk is received in a condition which makes testing difficult it is well to have a talk with the patron furnishing the milk in order to explain to him how the true test may be affected by not having the milk or cream in proper condition. Explain to him that it is better to take no sample of milk not in good condition and allow him the average test for the day or days when no sample is taken.

5. Partly churned and frozen milk. Sampling partly churned, sour or frozen milk is always attended with more or less failure in procuring a correct average sample. Churned milk unless heated enough to melt the churned butter fat cannot be sampled correctly. The reason is that the particles of butter fat float on the top of the milk and the granules are of such various sizes that even if the milk is well stirred before taking the sample, the granules will vary so much in size that it is impossible to obtain a correct sample without heating the milk sufficiently to melt the granules. In the case of frozen or partly frozen milk the water freezes first and forms crystals from which the fat globules may have been excluded. Therefore the frozen part contains much less fat than the liquid or semi-liquid portions of the milk. When sampling is done at the weigh-ean, while the milk is partially frozen, the sample invariably tests too high. To do justice to both the cream- 
ery man and the patron, the milk must either be thawed or no sample taken from it on that day. When badly frozon milk is warmed to $115^{\circ} \mathrm{F}$. to allow the mixing of it for sampling, it should be mixed thoroughly by pouring several times, and the sample should be taken quickly. The necessity of sampling milk quickly after $r$ it is warmed sufficiently to melt the churned butter fat, is due to the fact that in partly churned or frozen milk the fat when warmed enough to melt it, will easily float on top of the milk by reason of its lower specific gravity.

6. Care of composite milk samples. Be sure to put a preservative tablet in each sample jar before putting the sample of milk into it. Composite samples should be mixed daily and also whenever a new sample of milk is added, by giving the sample jar a few rotary motions. Thorough mixing is a great aid toward getting good results at the time of testing the milk. The sample jars should have tight fitting covers and should be lept in a closed case both in winter and summer. When sample jars are left open, especially in the hot summer time, cream adhering to the sides of the jars will form a tough layer-a mixture composed mostly of cream and casein-which will cause trouble in sampling for testing. (Farrington and Woll.**)

7. Preparing ccmposite samples for testing. Place the sample jars in water of a temperature of 115 $125^{\circ} \mathrm{F}$. and allow them to remain in the water until the milk is thoroughly warmed and the cream lique-

p. Farrington and Woll. Testing Milk and Its Products. Chap. II,
(904.

"Farrington and Woll. Testing Milk and Its Products. Chap. II,
p. 23,1904 . 
fied. Then mix thoroughly by pouring back and forth a few times and quickly take a sample with a perfectly graduated pipette. The composite sample should be warmed every time bèfore sampling for testing-in summer as well as in winter. The impression that summer temperature is warm enough for accurate sampling of composite samples for testing is erroneous. In my experience I have found that much of the trouble with variations in the test is due to neglecting to warm the composite sample before taking a sample for testing. The extra lime required in properly caring for milk samples is time well spent and the creamery man is repaid in the satisfaction given hoth to himself and his patrons by the knowledge that the test is absolutely correcet.

8. Receiving hand separator cream. The manner of receiving cream at factories varics greatly. This is due to the various methods employed in caring for the cream at the factory, and the manner of transporting the cream, whether by railroad or team transportation, or by the delivery by the individual patrons themselves. Since cireumstances and conditions vary in each factory it is necessary for each creameryman to study conditions existing in his factory and make arrangements to suit his individual case. But whatever arrangements are made for the receiving of cream, they should be durable, sanitary and convenient.

\section{METHODS OF COMPOSITE SAMPIING.}

9. Composite cream samples. The composite sample method of testing cream for fat content is 
quite widely used at present and when properly handled gives very good results. The fact that some creamerymen have not the proper facilities for caring for the composite samples, as well as the fact that some competitors test every day, has led to a system in some creameries of testing the cream c.very day as soon as it is received and sampled or as soon as the sample rase containing the samples from a route has arrived at the factory. Testing crcam for fat content soon after it is received at the factory and while it is still in a fresh condition, is becoming quite common and is received with much favor.

10. Sampling Case and Tubes. A suitable and convenient sample case holding a sufficient number of test tubes of any suitable size, as advertised in creamery supply catalogues, may be obtained. The hauler takes this case on the road and at the time of weighing each patron's cream he takes a well mixed sample with a small dipper or graduated tube, which delivers an aliquot part of the cream. and puts in into the sample tube, which is provided with a tight fitting cork. The cover of the case is so closely fitted that when the cover is closed the corks in the tubes cannot come out. This insures a safe delivery of the samples. On arriving at the factory these samples ar placed in a tank of warm water, if necessary; and when warmed and well shaken they are poured into jars containing a preservative. In this manner samples are added as often as cream is gathered during a period of a week, two works or a month, and is then testerl. 
Some creamerymen test each sample soon after the samples are brought to the factory and this system is to be recommended. While the method of making a composite test every week or two may give good results in the hands of an expert, still there are greater chances for errors than when cream is tested at each delivery.

11. Where cream is shipped by rail and the testing is done at the receiving station the cream buyer frequently takes a duplicate sample, places it in a screw-top jar and drops the jar into the can of cream. The eream is then shipped to the central station and upon its arrival there the cream is carefully poured into a strainer. The sample jars ar then taken from the strainer, sent to the testing de. partment where they are tested and the results obtained compared with the tests made at the receiving station. While this method may be a very satisfactory one from the standpoint of accuracy, yet considering it from the sanitary point of view, it is not to be recommended. The samples of eream should be sent by express and not put in the cream can.

12. Testing each patron's cream while he waits. In many cases where cream is delivered at the factory by the patrons themselves, it is tested while they wait. The cream can is washed and a check for the value of the cream is given to the patron. This method is employed in many factories in Minnesota and Iowa. In Wisconsin and Michigan the system is not so prevalent. Where the system of testing at each delivery of cream can be employed 
without too much inconvenience if should be user. It has hron found that the most uniform results in testing cream can be obtained by trsting it when fresh, without the addition of preservatives. The longer a composite sample is held before testing, the greater is the care requirrd in its preparation for testing.

13. Care of composite cream samples. A gond preservative should always be used. The sample jars should be well shaken daily by a rotary motion, and also whenever a new sample of cream is added. The cover must be well fitted to the jar and the jars should be kept in a cool. well 'nclosed compartment. The evaporation of moisture from badly kept samples is quite great and a little evaporation of moisture raises the test considerably above the actual fat content in the cream. The loss sustained in this way by the creameryman handling a large amount of "ream is enormous. No matter how well managed a creamery may be in other respects, the creameryman cannot stand the loss incurred in this manner-at least not for any considerahl" length of time. Unless the greatest care is axreised in the handling of composite cream samples, composite sampling should not be employed. C'rram samples should not be held longer than two wasks holding them for only one waek is butter, but testing wrory day is the best method. 


\section{CHAPTER II.}

\section{THE STRENGTH OF SULPHURIC ACID.}

\section{INDEX TO CHAPTER II.}

Par. No.

Page.

14. Sulphuric acid, specific gravity........... 19

15. Regulating the strength of sulphuric acid......19-20

16. Filling vessels from the carboy........... 20 



\section{CHAPTER II.}

\section{The Strength of Sulphuric Acid.}

14. Sulphuric acid should have a specific gravity of 1.82-1.83 (Farrington and Woll*) or not below 1.815 nor above 1.839. The strength of sulphurie acid is shown to some extent by the color of the fat. When the temperature of both the milk and the acid is $70^{\circ} \mathrm{F}$., and the fat shows dark flakes or is black, the sulphurie acid is too strong. When the fat is very light colored the acid is too weak. When it is found that the fat is blackened by too strong acid, add less acid. If the fat is too light, add a trifle more acid. By experience the operator will soon learn just how much acid to add in order to get a clear, well defined reading. Very few carboys of acid are exactly alike in strength , therefore a few tests made from any one carboy "will indicate the strength of the acid and the amount necessary can eásily be measured out for each milk or cream sample.

15. Regulating the strength of sulphuric acid. If the acid is too strong it can be made of standard strength by leaving the carboy open, as the acid weakens by being exposed to the air. Since it takes quite a time for the average creamery to use a whole carboy of sulphuric acid it is not deemed advisable to standardize the whole carboy at one time, but rather standardize one gallon at a time. When a carboy of sulphuric acid is all standardized there is

* Farrington and Woll. Testing Milk and Its Products, 1904. 
danger of it becoming too weak before all of it is used. Some buttermakers prefer placing a small quantity of water in an earthen jar and then pouring acid into it until it is of the proper strength. Great care must be used when water is used as a diluent, because when sulphuric acid is mixed with water great heat is produced. When the acid is poured into water it boils and foams and some of it may spatter over the sides of the jar and burn the hands or clothing. Sulphuric acid should always be handled very carefully since a drop of it on the clothing will burn a hole in it and on the hands may burn the skin and make it sore. It is well to have a weak solution of ammonia at hand, which should be applied at once in case of an accident with sulphuric acid. Water may also be used in place of the ammonia, if the latter is not at hand, as it weakens the acid and thereby renders it less destructive.

16. Filling vessels from the carboy. It is quite a task to fill bottles or any vessel from carboys without spilling acid or meeting with an accident. Some creamerymen draw acid from carboys with a pipette, not realizing that a slight accident might cost them their lives, by getting sulphuric acid into the throat. A convenient device is Burke's Pneumatic Acid Syphon, which can be $\bullet$ btained from creamery supply houses. 


\section{CHAPTER III.}

\section{TESTING MILK AND CREAM.}

A Dairy School is the proper place to learn how to operate successfully the Babcock Test. 


\section{INDEX TO CHAPTER III.}

Par. No.

I'age.

17. Temperature of sulphuric acld and nilk...... 23

18. Measuring milk into the test bottle......... 2:;

19. The mixing of mill and acid............. 2:;

20. Apparatus used for measuring arid into trest

bottles ........................24

21. Whirling the bottles and adding lot wairr......2t-26;

2y. Accuracy in testing cream a urewsity........ '26;

2:). How often should cream be tested?.........

24. Composite cream samples ..............26-27

25. Irandling fresh cream samples........... 27

26. Weighing cream for testing............ 27

27. Kind of cream swile to us.............. 28

28. Temperature of cream and nrid.......... 28

29. (a) Causes of defects in the $1 \mathrm{e}+1 \ldots \ldots \ldots \ldots .28$

(b) Causes of a cloudy and wary fat (rolumn... 2?

(c) Causes of black flakes and black fat rolumn 29

3). Mixing rean and acid................29-30

31. Whirling the bottles and addin: hot watrl. . . . :6)

:;2. How to get a clear reading...............;1)-;1

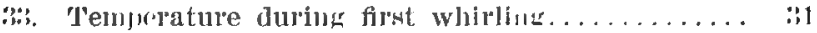

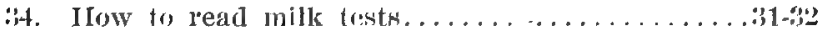

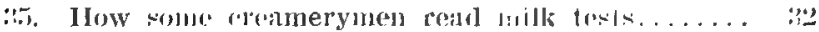

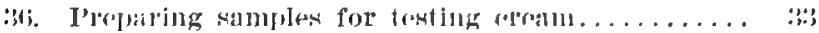

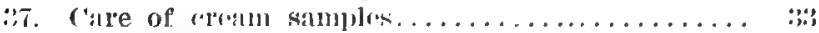

38. I'reluring kamplas for meaturing into a trast lottle .........................;

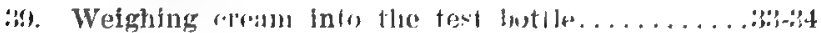

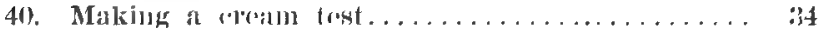

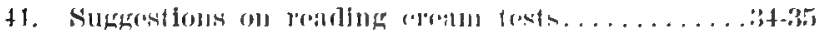

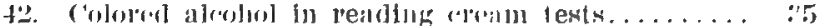




\section{CHAPTER III. \\ Testing Milk and Cream.}

17. Temperature of sulphuric acid and milk. The temperature of the acid and milk should be about the same-preferably between $60^{\circ}-70^{\circ} \mathrm{F}$. When the acid has a temperature of $65^{\circ} \mathrm{F}$. and the temperature of the milk is below $55^{\circ} \mathrm{F}$., add a trifle more acid; and when the milk is above $75^{\circ} \mathrm{F}$, add a trifle less acid. The reason for this is that the acid produces a certain amount of heat in the milk, which is necessary to produce a complete digestion of casein in the milk, in order to liberate the fat. Improper temperatures of either the acid or the milk, or both, is a frequent cause of a cloudy, flaky or charred fat column, and black or white specks in both milk or cream tests.

18. Measuring milk into the test bottle. Use a 17.6 c.e. pipette; fill up to the mark on the stem of the pipette. Place the point of the pipette in the mouth of the test bottle, and hold both the pipette and the test bottle in an inclined position. This allows the milk to run down the inside of the neck of the bottle, and avoids spilling the same. When the milk is all out of the pipette, blow through it gently in order that any drops adhering to the in. side of it may drop into the bottle.

19. The mixing of milk and acid. Whatever acid measure is used in measuring the acid into the test bottle, the bottle must be held in an inclined position, so that the acid may run down on the inside 
of the neck of the bottle. After adding the acid, the bottle should at once be given a rotary motion to the right and to the left, until the milk and acid are well mixed. The mixture should then have a - dark, but not a black color. If the color is too light, add a trifle more acid; if too dark, use less acid the next time.

20. Apparatus used for measuring acid into test bottles. It is not only necessary to use accurate apparatus for measuring sulphuric acid into the test bottles, but it is most desirable to have a reliable, accurate and convenient contrivance, by which sulphuric acid can be safely and quickly added to the milk or cream to be tested. Sulphuric acid is a dangerous fluid to handle and great care should be exercised when using it. For the successful handling and measuring of it into test bottles, various acid bottles, tubes and dippers are now on the market. Information regarding these may be had by addressing any reliable creamery supply house.

The practice of using a pipette for measuring acid into test bottles should be condemned. While one may not meet with an accident, there is always danger of making a mistake unexpectedly and endangering one's life by foreing acid over the stem of the pipette into the mouth and throat.

\section{Whirling the bottles and adding hot water.} Be sure to have an equal number of bottles directly opposite each other in the tester, in order to have a true balance. If this is not done the tester may run unevenly and may spoil both the test and tester; or it may brcak the bottles. 
After adding the acid to the milk in the test bottle and mixing the two thoroughly, the test bottles should be placed in the tester and whirled for five minutes at whatever speed is indicated in the directions given for the use of the machine. If through any unavoidable delay, the test bottles get too cool before the testing can be done, the bottles should be heated to about $140^{\circ} \mathrm{F}$. before placing them in the tester. If the samples are tested when too cold, the extraction of fat is not perfect, and the fat column is neither so clear nor so well defined as when the bottles have the proper temperature. This heating can be done, either by placing the bottles in hot water or in the tester, with the steam turned on until they are sufficiently heated. Then they may be whirled. The first five minutes whirling can be done at a high temperature - as high as $200^{\circ}$ F. without interfering with the accuracy of the test; but the last three or four minutes whirling should not be done at a high temperature-preferably $130^{\circ}$ F. When the testing is finished at too high a temperature, the fat column contracts and sags a little when the bottles are taken from the machine, and this settling of the fat may cause a smeary and ill defined meniscus, which interferes with the proper reading of the fat column. If the reading is done when the sample is too hot, the test will be too high. At the end of the first five minutes whirling, add hot soft water to fill the bottles up to the neck, and . whirl again for two minutes. After the second whirling, add sufficient hot water to fill the bottle to about the 8 th per cent mark. Soft water should 
be used, as this can be easily obtained by using condensed steam, or by boiling hard water.

\section{THE TESTING OF CREAM.}

22. Accuracy a necessity. In no phase of creamery butter making is accuracy so necessary as in the testing of cream. Creameries cannot be surcerssfully operated unless cream samples are properly prepared, accurately weighed into the test bottle, carefully and properly whirled and the test correct. ly read. The success and welfare of the creamery and its patrons depends upon the proper performance of this work.

23. Frequency of testing cream. It is desirable for several reasons that cream should be tested whil: in good condition instead of allowing the sample to get too cold. C'omposite samples should never under any cireumstances be more than four weeks old when tested, and having samples even this old is not to be recommended because evaporation of moisture is bound to take place even when samples are krpt unler the most favorable conditions. If lesting cream fresuently did not give better results than testing at long intervals the former would not mect with such great favor with reamerymen as it does. Cream should be tristed at least threr times every month.

\section{PREPARING CREAIM SAIVPLES FOR TESTING.}

24. Composite cream samples. Set the composite cream sampl: jars into water of a temperature bitween $115-120^{\circ}$ F. until well warmed. Then shake 
by a rotary motion several times or until the cream is well suspended and the whole well mixed. Pour from jar into a dipper or any convenient vessel and back again into the jar, repeating this several times. Then quickly take a sample and weigh the desired number of grams into a cream test bottle and set to cool to reduce temperature for adding acid.

25. Fresh cream samples. As a rulc fresh cream samples need not be warmed before taking a sample for testing. The warming of fresh cream samples is necessary only when the samples have been in transit or have stood for such a length of time as to allow the butter fat to rise to the top and form a heavy layer, or when the sample is too cold. The creameryman ought to be able to judge by the condition of the cream sample what treatment it should receive.

26. Weighing cream for testing. Cream for testing should be weighed, not measured. The reason for this is that butter fat is lighter than milk serum and the richer the cream the lighter it is. One quart of cream testing 50 per cent butter fat is not so heavy as one quart of eream testing 20 per cent butter fat. When we measure out 18 grams of 50 per cent eream we have less cream by weight than when we measure out 18 grams of 20 per cent testing cream. Even when the sanie pipette is used in measuring cream of the same richness the test will vary somewhat between sweet and sour cream, because the sour cream contains air bubbles and gaseous fermentations, while the body of the sweet cream is smooth and close. Weighing cream into 
cream test bottles is the only reliable and correct method. In weighing out cream tap the end of the beam of the scale once or twice to determine when enough cream is put into a bottle to give a true balance. A few drops more or less of rich cream will make quite a difference in the result obtained.

27. Kind of cream scale to use. There are a number of good scales on the market especially made for weighing cream samples. Any high grade, sensitive scale may be used. Do not weigh too many bottles at a time, as this will render the scale less sensitive. Good seales can be bought from any dealer in creamery supplies.

28. Temperature of cream and acid. The acid should be about the same temperature as the cream. Regulate the quantity of acid according to the strength and temperature of the acid and the temperature of the cream. Very rich cream should stand about five minutes after the addition of the acid before being whirled. This is to give the acid time to act upon the ingredients other than fat in the cream. Should the fat column not be clear, let the bottle get cold, then rehist and whirl again for two or three minutes.

29. Causes of defects in the test.

(a) Causes of too light color of butter fat.

1. Milk too cold.

2. Acid too weak.

3. Not enough acid.

4. Acid too colrl.

(b) Causes of a cloudy and wavy fat column. 
1. Not mixing acid and milk at once after acid is added to milk.

2. Not having proper temperature during testing.

3. Too low speed of tester, combined with weak acid.

4. Insufficient mixing and unclean acid.

(c) Causes of black flakes and black fat column.

1. Too strong acid.

2. Too much acid.

3. Too high temperature of milk or acid or both.

4. Not mixing acid and milk soon enough after adding acid.

30. The mixing of cream and acid. The addition of the acid to the cream, and the mixing of the same, is carried. on in the same manner as outlined for testing whole milk. When pouring the acid into the cream test bottle, the bottle must be held in such a way as to wash any cream adhering to the neck of the bottle down into the bulb of the bottle. Immediate mixing is absolutely necessary. If not mixed immediately the acid may act upon part of the cream and burn part of the butter fat, which will appear in the fat column when the testing is done in flocules or flakes resembling charred fat. Delay in mixing also causes the acid to act unevenly upon the casein and thereby may produce white flakes, which usually appear at the bottom of the fat column. In case delay in mixing the cream with the acid does not produce either of those defects, it may produce a mottled column of fat. This is evident in the Jower portion of the fat column by the appearance of a brownish or yellowish brown streak. 
When the acid is adder and well mixed with the cream, and the mixtiure turns black very rapidly, it is a sign that the acid is too strong. If, however, the mixture is of a light yellow shade, or nearly white, the chances are that the acid was either too cool or too weak, or the quantity added was insufficient. When the samples are all mixed, they must be placed in the tester at once, before they cool off too much. In case they should cool too much, they must be heated before being tested. If this is not done, the fat column may show various colors, due to the coolness of the butter fat before starting the testing. The separation will then be incomplete, which means that the reading of the test will be too low. because the butter fat is not all extracted or separated.

31. Whirling the bottles and adding hot water. The whirling of the cream test bottles must be done exactly as the whirling of the whole milk test bottles. They should be whirled three times. If the testing is done by an expert two whirlings may be sufficient and may give good results, but with a beginner two whirlings may not always be suffieient. All things considered, three whirlings are better than two, but there are creamerymen who whirl the bottles only once.

32. By adding hot water twice the reading will be clear, the butter fat column bright, and the meniscus will be well defined. Some creamerymen advocate the addition of a little hot water before the first whirling.

In case a sample of cream produces a discolored 
or frothy fat colum, this can be remedied by allowing the sample to cool, when through testing, until the butter fat hardens. Then reheat, whirl for two or three minutes and read at once. This will, as a rule, produce a very clcar reading. Since hard water has a tendeney to favor foam on the top of the fat colum, soft water should be used; if this cannat be had use condensed steam, or boil ordinary water.

33. The temperature during the first whirling may be as high as $200^{\circ} \mathrm{F}$. and yet not necessarily interfere with the correct result of the test, but if this temperature were employed during the two last whirlings, and the bottles read immediately after the testing were completed, the reading would invariably be too high, and air bubbles might appear in the lat column. Therefore, the temperature during the two last whirlings ought not exceed $140^{\circ} \mathrm{F}$.

\section{THE READING OF MILK AND CREAM TESTS.}

34. Reading milk tests. According to Farrington, milk tests should be read from the extreme bottom line of the fat column to the extreme top of the meniscus (see Fig. I, Book II). The reading from A to $D$ represents the true fat content of the milk tested. C to D is the space the meniscus takes up, which may be termed the per cent of meniscus. This space usually represents .2 per cent on the reading of the test, but not .2 per cent of the reading. Babcock found that about .2 per cent fat adheres to the inside of the test bottle and does not find its way into the neck of the bottle with the other fat. The 
hollowness in the top of the fat column (the meniscus) represents in the milk bottle about .2 per cent, which is equal to the amount of fat which adheres to the inside of the bottle. In order to have the reading represent the total fat in the milk, the full column of fat should be read. In ordinary creamery practice, the meniscus of the milk tests is not usually included in the reading. At the average creamery the fat column is usually read from the bottom of the fat column (a) to the bottom of the meniscus (c). See Fig. I, Chap. V of Dairy Arithmetic. It is claimed by most creamerymen that this reading is necessary in order to get sufficient overrun.

35. How some creamerymen read milk tests. It is claimed by up-to-date creamerymen, who seem to be close observers of their business transactions, that in order to recover an amount of butter fat, plus mechanical losses and shrinkage, equal to the butter fat bought in the cream, the whole meniscus must not be included in the reading of either milk or cream tests. Some claim that they have found that in order to get the recently requested overrun, based upon market returns of butter sold, either on milk or cream, the whole meniscus in either case cannot be included in the reading of the fat column. Also that the reading should not be done at a lower temperature than $110^{\circ} \mathrm{F}$, nor higher than $130^{\circ} \mathrm{F}$. At a lower or higher temperature than those indicated the fat column, it is "laimed, is not in good condition for proper reading. 


\section{CONDENSED DIRECTIONS FOR TESTING MILK AND CREAM.}

36. Preparing samples for testing cream. Cream should always be poured from one vessel into another before taking a sample. Cream that is frozen must be thawed out before it can be properly sampled. The dipper sampler gives very good results, but the sampling tube gives the most accurate results.

37. Keeping the samples. Sample jars must have tight fitting covers and should be kept in a closed compartment. For composite samples the preservative used should be thoroughly mixed with the milk or cream. The mixing should always be done with a rotary motion. Lack of attention to samples is a frequent cause of abnormal variations in the test. The samples should not freeze; they should be looked after daily, and the samples taken should not be too large: Large samples entail an unnecessary loss.

38. Preparing samples for measuring into a test bottle. Samples should be heated to about $115^{\circ} \mathrm{F}$. and should be mixed until they are absolutely uniform and the cream is all well suspended. The higher the temperature of the cream sample, the more liquid it is and the easier it is to take a uniform sample. In case of a Iumpy sample, shake vigorously before taking the sample for testing. Samples which have been partly churned or frozen should be very thoroughly mixed, and then sampled as quickly as possible.

39. Weighing cream into the test bottle. Use delicate balances and keep them in perfect order. Be 
sure to test the weights for accuracy before using them. If possible never use less than nine grams of cream for testing; eighteen grams is even better than nine. Never measure the cream, but always weigh it, as this is the only correct and reliable method. No other method should be tolerated. Be very careful to weigh out the exact amount. because a few drops too much or too little of rich cream means a great loss to the creameryman or to the patron.

40. Making the test. If you use nine grams of cream, use about six grams of water and then add acid as for an eighteen gram sample. See that the fat colum is always clear; if it is not, change the quantity of acid and determine the exact quantity by experience. Use soft, hot water for filling the bottles. The first whirling may be done at a comparatively high temperature, but the two last whirlings should always be done at a temperature of about $125^{\circ}$ to $140^{\circ} \mathrm{F}$. The tester should run smoothly and should be run neither above nor below speed.

41. Suggestions on reading cream tests. Hold the bottle on a level with the eye and then read from the bottom of the fat column to nearly the bottom of the upper meniscus: The reading should be done at a temperature of about $130^{\circ} \mathrm{F}$. If possible, when nine gram samples are used, use a bottle on which the reading is based on eightcen grams. Multiplying the reading by two increases an error, if one has becn made. If bottles get cold before reading can be done, place them in a hot water bath of a temperature of $130^{\circ} \mathrm{F}$. for fifteen minutes. The 30 per cent, six inch, eighteen gram, and 30 per cent or 50 per cent nine inch cream test bottles are con- 
sidered most accurate. The use of the 50 per cent six inch cream test bottle should be avoided. Buy only first class bottles, as these are most accurate, but all bottles should be tested for correctness of calibration. Even bottles which are guaranteed correctly calibrated cannot always be depended upon as accurate.

Note: For further information regarding the reading of cream tests, comparison of cream test bottles, and mathematical calculations involved in testing cream, consult Book II, Chapter $\mathrm{V}^{\mathrm{r}}$

\section{Using colored alcohol for reading cream tests.} Butter fat has a specific gravity of about .90. Alcohol has a specific gravity of about .816 , and amyl alcohol has a specific gravity of .8294 . It is advisable to be sure to get the properly colored amyl alcohol for this use.

The adding of the colored alcohol must be done carefully, so that the fat and alcohol do not mix, and so that the alcohol does not run down between the fat column and the neck of the bottle.

Some of the colored liquids on the market seem to mix very readily with the butter fat and those which do this are likely to cause considerable trouble. An experienced cream tester can read the tests more quickly and accurately without the addition of the colored alcohol. With some of the colored liquids now used, the upper line of the fat column had an upward curve, which made the exact reading more difficult than when no colored liquid was used. Therefore, I wish to warn the inexperienced operator against the use of a colored liquid unless he is sure that it is reliable. 


\section{CHAPTER IV.}

\section{ACIDITY TESTS.}




\section{INDEX TO CHAPTER IV.}

Par. No.

I'ilge.

4.. Mimm's acidity test $\ldots \ldots \ldots \ldots \ldots \ldots \ldots \ldots \ldots \ldots \ldots$

11. How to find per cent a(idity............ ;is

45. Mann's acidity test apparatus............. 89

46. The Farrington alkaline tablet solution........ 40

47. The standard alkaline acidity test apparatus.... +

48. Farrington rapid method acidity test......... 41

49. How to prepare the solution............. 41

50. How to operate the test................ +1

51. Necessary apparatus $\ldots \ldots \ldots \ldots \ldots \ldots \ldots \ldots \ldots+1$

50. Uniformity in expressing acidity in milk or cream 42 


\section{CHAPTER IV.}

\section{Acidity Tests.}

43. Mann's acidity test. The solution is prepared by dissolving forty grams of caustic soda in water, making a total volume of 1000 e.c. This makes the normal solution. A tenth normal solution, which is the strength generally used at present for testing acidity, is made by dissolving four grams of caustic soda in one quart of water. One c.c. of the tenth normal solution contains .004 grams of soda and will neutralize .009 grams of lactic acid. Mann, in his directions for using this method, recommends the use of a 50 c.c. pipette for measuring the cream or milk. A 50 c.c., a 20 c.c., or a 17.6 c.c. pipette may be used. In using the different sizes of pipettes factors may be used to simplify the process. These factors are found by dividing .009 by the size in c.c. of the pipette and multiplying the quotient by 100 . Factors for different sized pipettes are as follows:
$(.009 \div 50) \times 100=.018$
$(.009 \div 20) \times 100=.045$
$(.009 \div 25) \times 100=.036$
$(.009 \div 17.6) \times 100=.051$

How to use the factors: Use .018 with a 50 c.c. pipette; .036 with a 25 c.e. pipette; .045 with a 20 . c.c. pipette; and .051 with a 17.6 c.e. pipette.

To illustrate: Suppose a 50 c.c. pipette is used in taking a sample of cream, and the solution used to neutralize the acidity is 30 c.e., the factor is .018 . 
The acidity in the erearn would be $30 \times .018$ or .54 per cent, or

$$
\frac{30 \times .009}{50}
$$

44. Suppose a 17.6 c.c. pipette is used, requiring 10 c.c. of solution to neutralize the acidity, the factor which is found as follows $(.009 \div 17.6) \times 100=$ .051 and the acidity of the cream would be found by multiplying the factor by 10 , or $.051 \times 10=.51$ per cent.

Acidity of cream $=\frac{17.6}{10 \times .009} \times 100=.51$ per cent, or Acidity of cream $=.051 \times 10=.51$ per cent, or for practical purposes the acidity may be found by dividing 10 c.c. by 2 , giving the acidity of .50 per cent. The factor which corresponds with each size of pipette is to be multiplied by the number of c.c. of solution used to neutralize each sample. The result is the acidity in per cent. These calculations are based upon a one-tenth normal solution. The figure .009 is the number of c.c. of lactic acid neutralized by one c.c. of the solution used. As a rule when Mann's acid test is used, a 50 c.c. pipette is used. Those who are accustomed to the use of the 50 c.c. pipette usually give the number of c.c. of solution used, from the burette, and not the per cent of acidity in the milk or cream. Acidity should, however, be expressed in per cent, as this is the only logical and reasonable method of expressing it. If the solution weakens from age before it is all used, a fresh solution of standard strength should be procured. 
45. Mann's acidity test apparatus. 1 iron burette stand, with cork lined clamp; 1,50 c.c. burette, graduated in tenths of a cubic centimeter; 1,50 c.c. pipette; 1,50 c.c. beaker; 1 glass funnel; 1 glass stirring rod; 1 pinch cock and rubber connections, with glass tip; 1 gallon of one-tenth normal solution, and 14 -oz. bottle of phenolphtalien.

46. The Farrington alkaline tablet solution. The Farrington tablet solution can be used in three ways: First by dissolving five tablets in 85 c. c. of soft water; second by dissolving five tablets in 97 c. c. of soft water, and third by dissolving one tablet in one ounce of soft water. In using the first method a 20 c. c. pipette is used. One c.c. of the solution (five tablets to 85 c.c. of water) will neutralize .01 per cent acidity in the sample tested, and 20 c. c. of the solution would neutralize .20 per cent acidity. In using the second method (five tablets to $97 \mathrm{c}$. .c. of water) a 17.6 c.c. pipette is used. The number of c.c. of solution used represents, as in the first method, the same amount of acidity neutralized; thus, if 20 c. c. of solution have been used the acidity is .20 per cent.

This method is a very desirable one as it needs no mathematical calculation and a 17.6 c. c. pipette can be found in every creamery. The tablets will keep better than a solution; they can be procured by mail from creamery supply houses and the solution is very easily prepared. With Mann's method the solution is as a rule prepared by a chemist. 
47. Farrington standard acidity test apparatus. 1 Babcock 17.6 e. c. pipette; 1 white cup; 2,100 c. c. graduated cylinders; 1 box of 1,000 tablets.

48. Farrington rapid method acidity test. This method for determining acidity in milk or cream is used mainly where quick results are desired and when a great number of tests must be made in a short time. For selecting milk for pasteurizing or for testing milk quickly for city supply this test is indispensable because it is convenient and accurate and the solution is very easily prepared.

49. How the solution is prepared. Take one alkaline tablet and dissolve it in one ounce of soft water and when dissolved use as needed. Do not prepare more of the solution than is needed for a day or two. When all is not used snon after preparing pour it into a bottle and cork well or else throw it away ard prepare a fresh solution when needed.

50. How to use the test. This test is based upon the use of equal quantities of cream or milk and solution. A measure of the same size as that used for measuring the cream or milk must be used for measuring the solution. One measure of the solution added to an equal measure of milk or cream represents .10 per cent acidity and two measures represents .20 per cent, and so on. Half per cents can be obtained by a half measure of the solution. Stop adding solution when a light pink shade appears. This applies to all the acidity tests mentioned. 
51. The necessary apparatus. 1 white cup, a good sized one preferred; 1 measure for measuring cream and solution, any size preferred, may be 5 grams, 6 grams or 8 grams. This method can be used in testing cream for acidity for butter making. Results are quite accurate when test is properly handled.

52. Uniformity in expressing acidity in milk or cream. Acidity in milk or cream should always be expressed in per cent, and not by degrees, by cubic centimeters or by the name of a certain acid test. When we consider that there are several different acid tests now in use by which the acidity in milk or cream is determined, and that each test is based upon different mathematical calculations, the necessity for expressing the results on one basis is obvious. The different quantities of solution used to produce a given coloration, or to neutralize a given quantity of lactic acid, varies with each test. Therefore, it seems that the results obtained by the use of any one test can best be expressed in per cent. Acidity expressed in per cent carries with it a definite quantitative meaning, while when the per cent of acidity in milk or cream is expressed in cubic centimeters, in degrees, or by the name of a certair: acid test, the meaning is not always clear and definite. 


\section{CHAPTER V.}

\section{COMMERCIAL STARTERS IN BUTTER MAKING.}

Success in butter making rests primarily upon the extent of our knowledge of the fundamental principles involved in controlling lactic acid fermentations. 


\section{INDEX TO CHAPTER V.}

Par. No.

Page.

53. Pure lactic acid cultures.............. 45

54. Methods change as we gain knowledge....... 45

55. Commercial starters in buttermsking......... 46

56. Condensed directions for buildiug up the startoline and starter from a jure culture of lactic ferment. . ................. 47

57. Selection of milk for starter............. 48

58. Preparing milk for the first propagation....... 49

59. Adding the lactic ferment culture.......... 49

60. Handling the second propagation.......... 50

61. Handling the third propagation........... 50

62. Handling the startoline ............... 51

63. Startoline incubators ................ 52

64. Handling the starter ................ 52

65. Temperatures and quintities ............. 53

66. Temperatures influence results ...........53-55

67. Using starters ever'y other day........... 55

68. Effect of too high acid starters........... 55

69. Vigor of starters and how controlled......... 50

70. Ripening starters ................. 56

71. Starters a check on gassy fermentation....... 57

72. How gassy crean appears.............. 57

73. IIow gassy cream churns............ 57-58

74. Gassy fermentation kills flavor in butter...... 58

75. Lactic acid ripened cream.............. 58

76. Average acidity in starter............. 58

77. Regulating the quality of acid in both startoline and starter ..................... 59

78. Regarding pink or brown starter........... 60

79. Burnt flavor in starter due to milk used....... 60

80. A starter scoring blank............... 61

81. Judging starters ................... 61

82. Regarding glassware ............... 62

83. Utensils which should not be nced.......... 63

84. Gassy fermentation and flies.............. 64

85. Starters in cream ripening.............64-65

86. Raw or pasteurized cream............. 65

87. Per cent of starter to be added to cream....... 196

88. Richness of cream and per cent of starter.....66-67

89. 'Temperature and time in ripening cream...... 68

90. A few things to remember regarding starters.... 68 


\section{CHAPTER V. \\ Commercial Starters in Butter Making.}

53. Pure lactic acid cultures. In American as well as in European butter making the pure lactic acid culture has played an important part in the last decade. It became known that lactic acid fermentation was the main factor in giving to butter the characteristic flavor and aroma so pronounced in butter made from well ripened cream. Pure lactic acid bacteria, in sufficient numbers, have a tendency loward retarding and destroying the growth of undesirable bacteria in cream. Authorities on dairying recognize the value of a pure lactic acid culture as a means of improving the poorer grades of cream and insuring the production of more uniformlý good butter. Since modern dairy education demands a knowledge of the handling of pure cultures, and of their use in butter making, it seems adrisable to emphasize the need of a pure culture in creamery butter making.

54. Methods change as we gain knowledge. In proportion as we gain knowledge of the use of a pure lactic ferment eulture in butter making do our methods change and readjust themselves to changed conditions. Where improper methods still prevail financial returns are less and poor quality of butter and cheese is not uncommon. Even with modern methods of manufacture there are times when the quality of butter and cheese is not as good as it might be. This in a measure is due to the lack of 
knowledge of a wonderful flavor-producing organism called the lactic acid germ. This little plant is today looked upon as the greatest money making organism of any affecting milk and its products. The lactic acid germ is the most vigorous germ, under normal temperatures with which the dairyman has to deal ,and when properly cared for it is his best friend and is used as a medium through which a great many difficulties arising from abnormal fermentation in milk or cream may be overeome. By its careful use abnormal fermentations affecting the quality of butter may readily be prevented and the best flavor insured. It is known to butter makers that by using a good pure culture of lactic ferment in the manufacture of their product, the value has been increased from one to two cents a pound; in some cases as much as five cents.

55. Commercial starters in butter making. Butter making today without a starter is like running machinery without oil. Whenever a prosperous creameryman is found you are sure to find that a commercial starter is used in the manufacture of his butter because pure lactic acid enhances the keeping quality of butter.

Various methods of handling and souring cream have been tried, but so far the best results have been obtained by using a large quantity of a pure starter, and ripening the cream to about .55 per cent acidity. Lactic acid acts as a germicide on obnoxjous germs and prevents the development of bad flavors and taints present in cream or milk. 
A good lactic ferment is a great purifier and should be used by every butter maker. Gas or yeast organisms have an injurious effect on the aroma, flavor and body of butter.

As a further proof of the value of a pure lactic acid culture in butter making I may mention that at the Educational Scoring Exhibitions now carried on in all dairy states the highest average scores are, in every instance, received by exhibitors of butter and cheese who use a pure culture.

56. Condensed directions for building up the Startoline and starter from a pure culture of lactic ferment.

(a) Preparing the Startoline or mother starter.

1. First we inoculate a small quantity of pasteurized milk with a pure culture of lactic ferment, known in the market as lactic ferment culture. This when coagulated makes the first propagation and is called Startoline. Startoline is the small quantity from which larger quantities are grown.

2. The next day when this milk is sour or sufficiently ripened, a small quantity of it is added to fresh pasteurized milk. This is the second propagation.

3. A third propagation is made in the same way, by adding a little of the second propagation to pasteurized milk, a fourth in the same way, and so on day after day until the starter shows signs of deterioration, when it becomes necessary to prepare a new batch of Startoline with a fresh commercial starter. 


\section{(b) Preparing the starter.}

While the propagation of Startoline is carried on day after day for an indefinite time, as before indicated, a sufficient quantity of it should be prepared every day after the second or third propagation, not only to perpetuate the Startoline itself, but also to inoculate the starter milk. The starter when fully ripened is used in the cream for butter making or the milk for cheese making.

In carrying out the processes as outlined above the first thing to be taken into consideration is:

57. The selection of milk. To obtain the best results it is necessary to use only the cleanest, sweetest and freshest milk, from a healthy herd and from one having few strippers. Stripper milk being too viscous and lacking fine flavor, is not as good for starter making as fresher cow's milk. Mixed milk as it is generally delivered at the creamery or cheese factory is unsatisfactory for making a first-class starter. The best milk, either evening or morning milk, should be used. An observant operator soon learns which of his patrons brings the best milk for starter making and this is the milk to use. Milk having an old taste will impart the same to the starter. In fact defective milk will produce a defective starter even though the best of care has been exercised in the handling of it. An experienced butter or cheese maker soon learns how to tell old or kept over milk from new or fresh milk even though both are cold. The new or morning milk always is soft and velvety to the palate, while old milk is harsh to the palate and lacks fineness of flavor. 
58. Preparing milk for the first propagation. (Pernot.*)-The preparation of milk for the propagation of a pure culture is very simple. Select two quarts of good sweet whole milk or skim milk for this purpose. (Either may be used satisfactorily but sweet whole milk gives the Startoline more of a smooth, pleasing taste than skim milk does.) Set two vessels each containing one quart of milk jnto water and heat it to $170^{\circ} \mathrm{F} .-190^{\circ} \mathrm{F}$. and hold at this temperature for about forty minutes. Cool quickly to $80^{\circ}$ $F$. and it is then ready for the addition of the pure culture. For very large creameries use a large sized bottle of pure culture and use one gallon of milk divided into two jars of two quarts each. An excellent method is to place the jars of selected milk in a steam tight, wooden, tin-lined box the temperature of which can be perfectly regulated and pasteurization assured. Another method is to tie parchment paper over the necks of the jars and then place the jars on a shelf through which steam is conducted. Turn a large tin pail over them, turn on the steam and heat as mentioned above. Then cool by placing the jars first in warm water (to avoid breaking them) and then gradually running cold water around them.

59. Adding the lactic ferment culture. When the milk is prepared as previously directed get the little bottle of pure culture, clean the sealing wax carefully from the neck of the bottle and empty one-half of the contents into each bottle of the pasteurized milk. Now close the jars or vessels con-

* Pernot, E. F. Bul. No. 83. Oregon, 1904. 
taining the milk, being careful not to get any dust or impurities into the milk. Shake the jars five or six times at intervals of three or four minutes, then let stand at a temperature of about $80^{\circ} \mathrm{F}$. until nicely coagulated. This is called the first generation and each consecutive propagation is one generation. Thirty consecutive propagations are thirty generations. Each souring is considered one germ life and therefore we have one generation at every propagation. Whether the milk is pasteurized in the same vessel in which the Startoline is to be grown or in a separate vessel and the Startoline jars sterilized before putting the milk into them, the milk should always be in the jars before the culture is put into it. After the culture has been added to the milk and it has coagulated it is called "Startoline."

60. The second propagation. The milk used for the second propagation is handled the same as the milk used for the first inoculation of the pure culture, except that the temperature at which the milk is set should be $75^{\circ} \mathrm{F}$. or about five degrees lower than the temperature used for the first propagation. This temperature may vary slightly according to the methods employed and to the skill of the person handling the starter. Add about two tablespoonfuls of sour milk from the first propagation to each quart of the milk for the second propagation and use.about the same proportions for each succeeding propagation.

61. The third propagation. Whenever it is necessare to make more than two propagations of a pure culture before it is used for inoculating the starter 
milk to be used in butter or cheese making, set the milk for the Startoline at about $70^{\circ} \mathrm{F}$. If the second propagation is used to inoculate the starter milk, set the starter milk at about $72^{\circ} \mathrm{F}$. in winter, allowing a few degrees for the lowering of the temperature. Set it at about $68^{\circ} \mathrm{F}$. in summer. The subsequent propagations may be set at temperatures ranging from $65^{\circ}$ to $70^{\circ} \mathrm{F}$., depending upon the quantity of Startoline used and temperature of the room.

62. Handling the Startoline. From the foregoing we see that we obtain our Startoline by inoculating pasteurized.milk with a pure lactic ferment culture and allowing it to coagulate. For the perpetuation of the Startoline the milk may be taken daily from the can of milk pasteurized for the starter, or it may be prepared as directed on page 49. Have the pasteurized milk and the Startoline jars ready, break up the coagulated Startoline by shaking and add about two tablespoonfuls to each jar filled nearly full with the pasteurized milk. Now shake thoroughly and set at a temperature of $65^{\circ}$ F. to $70^{\circ} \mathrm{F}$. Vary the quantity of Startoline added to cach jar according to the conditions of the Startoline and to possible variations in temperature during the ripening process. In ordinary room temperature $\left(68^{\circ} \mathrm{F}\right.$.) when two tablespoonfuls of Startoline are added to the milk it will coagulate in 12-18 hours. When the Startoline is in danger of getting overripe before it can be used break it up thoroughly and pour out about one-half; then fill the jar again with pasteurized milk, shake well and set 
in a cool place. This will lower the acidity and give the lactic acid germs a chance to multiply and retain their vitality which is rssential in growing good Startoline.

63. Startoline incubators. There are various contrivances on the market made especially for the purpose of handling the Startoline or "Mother Starter." These may be obtained from any reliable creamery supply housc at a reasonable cost. They are so made that a uniform temperature can be maintained during the ripening of the Startoline. This uniformity of temperature is necessary for obtaining good results. Where electricity can be had a very uniform temperature is easily maintained by placing one incandescent bulb in the interior of the incubator and turning on the electricity. A common, double-walled, tin-lined, wooden box can be used with success in this manncr. In very cold weather if there is danger of the room temperature dropping too low, two bulbs may be used instead of one.

64. The handling of the starter. The care to be exercised in selecting, heating and cooling milk for the starter is not necessarily different from that to be exercised in the handling of the milk for the Startoline. The can or cans used for making the starter should bewell tinned and all seams should be smooth to allow jt to be easily and thoroughly cleaned. old cans, especially when the tin is worn off or when they are somewhat rusty, will impart a "tin can" flavor to the milk which will impair the usefulness of the milk for starter making. The best starter cans are those which produce a vigorous whirling 
of the milk to prevent scorehing while heating and 10 facilitate rapid cooling. The per cent of Startoline necessary to be added to the starter milk depends, first, on the temperature of the starter milk when the Startoline is added; second, on the average temperature at which the milk will be kept during the ripening period; third, on the time allowed for the starter to ripen before it is 10 be used; and fourth, on the vigor and acidity of the Startoline added.

65. Temperatures and quantities.

TABLE I.

Temperatures and Qumtities.

\begin{tabular}{|c|c|c|c|c|c|c|}
\hline \multirow{2}{*}{$\begin{array}{l}\text { Quitn- } \\
\text { tity of } \\
\text { Milk. } \\
\text { lbs. }\end{array}$} & \multirow{2}{*}{$\begin{array}{c}\text { Quan. } \\
\text { uf Milk } \\
\text { wliprox. } \\
\text { gral. }\end{array}$} & \multicolumn{2}{|c|}{ Range of Temperatures } & \multicolumn{3}{|c|}{$\begin{array}{c}\text { Startoline added ex- } \\
\text { pressed in }\end{array}$} \\
\hline & & In Winter & In Summer & Lhe. & P'er Ct. & Qts. \\
\hline 100 & 12 & $68-70^{\circ} \mathrm{F}$ & $62-67^{\circ} \mathrm{F}$. & $1-5$ & $1-5+$ & $\frac{1}{2}-2 \frac{1}{2}$ \\
\hline 200 & 24 & $68-73^{\circ} \mathrm{F}$ & $63-67^{\circ} \mathrm{F}$. & 210 & $1-5$ & 15 \\
\hline$: 00$ & 36 & $68-73^{\circ} \mathrm{F}$. & $63-68^{\circ} \mathrm{F}$ & $3-15$ & $1-5$ & $1 \frac{1}{2}-7 \frac{1}{2}$ \\
\hline 400 & 48 & $8,8-71^{\circ} \mathrm{F}$ & $61-68^{\circ} \mathrm{F}$. & +20 & $1-5$ & $2-10$ \\
\hline 500 & 60 & $68-70^{\circ} \mathrm{F}$. & $65-68^{\circ} \mathrm{F}$. & $(i-25$ & $1+-5$ & $: 312 \frac{1}{2}$ \\
\hline 1000 & 120 & $68-70^{\circ} \mathrm{F}$. & $68-70^{\circ} \mathrm{F}$ & $15-40$ & $1 \frac{1}{2}-4$ & $7 \frac{1}{2}-20$ \\
\hline 5000 & 600 & $68-70^{\circ} \mathrm{H}$ & $68-70^{\circ} \mathrm{F}$. & $100-., 000$ & $2-108$ & $50-250$ \\
\hline
\end{tabular}

66. Explanation of conditions. The larger the per cent of Startoline added to the starter milk and the higher the temperature at which it is kept, the short$\mathrm{er}$ is the period of time between the inoculation and coagulation. The smaller the per cent of Startoline added to the starter milk and the lower the temperature at which it is kept the longer will be the period of time between inoculation and coagulation. It will be noticed in Table I that the range of temperatures given are not so great when large quantities of starter milk are used as when smaller quantities 
are used. This is due to the fact that the larger the quantity of milk the less does it change in temperature during the ripening period. Small quantities of milk naturally are more subjected to changes in temperature. This is especially true in very cold and very warm weather when temperatures go to either extreme.

Being influenced by these conditions the average temperature at which the starter can be grown may vary from $64^{\circ} \mathrm{F}$. to $68^{\circ} \mathrm{F}$. with practically the same results.

When the starter is at the point of coagulation at a temperature higher than $64^{\circ} \mathrm{F}-66^{\circ} \mathrm{F}$. and is not to be used at once, immediate cooling is imperative, since the starter is likely to become overripe and whey off, a condition in which a starter is almost unfit for usè, as its action is greatly impaired by this condition and the effect it should produce is partly or wholly destroyed. It is a good plan to see to it that the starter coagulates at a temperature lower than $64^{\circ} \mathrm{F}$. if it is not to be used at once, sinec when coagulation takes place at a comparatively low temperature the texture of the starter is more likely to be loose and silky. When in this condition it will when poured have the appearanco of nicely ripened cream and will leave no streaks, nor will it show specks or particles of curd. On the other hand starters grown at too low temperature and for too long a period of time before coagulation invariably develop sour, slightly bitter, rank or flat flavors, thereby impairing their usefulness for perpetuation. It is perhaps needless to say that the Startoline 
should not be saved out from the starter. During the hot season the starter should not be inoculated in the morning for the next morning's use unless perfect control of temperature can be had, because when it has developed quite a degree of acidity before cooling in the evening it is difficult to prevent its becoming overripe before it is used next morning. When the starter milk is inoculated in the evening with Startoline of good quality and proper acidity the starter will as a rule be in good condition in the morning. During cool weather, however, there is not much danger of the starter spoiling when set in the morning, cooled a little before evening and the ripening finished at a lower temperature.

67. Using starters every other day. When the starter is used only every other day it is always better to renew the Startoline daily and reheat the starter milk the second day than to hold over both the starter and Startoline. By holding over the Startoline and starter the development of acid may be too rapid and by producing an excess of acid the quality of both the Startoline and starter is impaired and may be spoiled altogether, or cheesy, curdy or vinegar flavors produced.

68. Too high acid starters. It is a well known fact that after the acidity in the Startoline or starter has developed to about .8 per cent the strength of the acid present retards and finally prevents the production of a good quality of lactic acid necessary in butter or cheese making. After such a stage is reached the quality of the acid undergoes changes. 
The first change noticeable is the change to a vinegar flavor, a little later it will show signs of wheying off and then in many cases a digesting of the "urd begins. All these signs are indications of the weakening of the lactic acid germ. Therefore great care must be taken to prevent the development of too high acid in the Startoline. It should not have more than .7 per cent acid at any time and it is best not to exceed .65 per cent in order to maintain a fine quality of acid in both Startoline and starter. A high degree of lactic acid weakens the lactic acid germ and in many cases kills it.

69. Vigor of starters. Starters seem to have reached the maximum activity when they have developed about .60 per cent acidity. (Russell.*) Creamerymen have noticed that starters are not always of the same vigor, even when there seems to be no special reason for any variation. When starters are ripened too high the activity is lessened and the starter is said to be "slow" or is "going off," and a few successive high ripenings may spoil the starter altogether. When the acidity has reached .70 or .80 per cent the starter is losing its vigor as well as its fine flavor. Avoid too high acid in the starter as well as too slow ripening. Both have a bad effect upon the flavor and vigor of the starter.

70. Ripening starters. The degree of acidity to which starters are ripened before being added to cream varies according to reports from 100 of the best creamerymen in the United States from .45 to .80 per cent. This variation is due 10 different meth-

- Russell, H. L. Wis. B. M. Assn. Fifth Annual Report, p. 58. 
ods of handling and ripening cream and different methods of using the starter. The degree of acidity also depends upon the kind of cream handled-that is, whether it is whole milk or hand separator cream.

How gassy fermentation in cream affects the quality of butter.

71. Commercial starters a check on gassy fermentation. That gassy fermentation in eream has a detrimental effect on the aroma, flavor and body of butter was clearly shown by results obtained from experiments carried on while instructor in practical buttermaking at the Wisconsin Dairy School. A lot of cream was pasteurized, and divided into two parts. One part was ripened with a pure lactic acid culture, and the other lot was ripened with a culture of gassy organisms prepared in the bacteriological department of the School of Agriculture. The lot of cream which was inoculated with the gassy culture was held at ripening temperature for about ten hours, and at the end of that time showed a re-action of .55 per cent on the acid test. The cream was held cold for several hours and then churned. Everytbing incident to the ripening, cooling and churning of the cream, and the washing and salting of the butter was performed in the usual way.

72. Appearance of the gassy cream. The body was slightly huffy and porous; the color rather whiter than that of ordinary cream, and the flavor was flat, oily and yeasty.

73. Churning of gassy cream. This cream did not churn as ordinary cream does. The granules for some reason did not solidify during churning as 
they do in other cream. (Fleischmann*.) The butter was washed and worked in the usual way, and when examined at the conclusion of working, was found to have a mushy, soft, oily body. The flavor was oily, greasy, yeasty and slightly alcoholic. The bouquet was altogether absent.

74. There is no other fermentation in cream more destructive to the natural flavor, aroma and body of butter than yeasty. or gassy fermentation. Therefore it is necessary to use a pure lactic ferment culture-a real lactic acid producer-to check the growth of undesirable fermentation in cream, and produce fine flavored as well as fine textured butter.

Since the average consumer is willing to pay a higher price for fine flavored butter than for the poorer grades, it is the duty of the creameryman to use a pure lactic ferment culture, in order to achieve the best results.

75. Lactic acid ripened cream. This lot of cream had a fine flavor and aroma, and a smooth body. It churned in the normal way and the butter made from it was very fine and clean.

76. Grouping one hundred creameries showing the degree of acidity to which the starter was ripened.

TABLE II.

Grouping One II undred Oreameries Showing the Degrce of Acirlity to Which the Starter Was Ripened.

\begin{tabular}{|c|c|c|c|c|c|c|c|c|c|}
\hline $\begin{array}{l}\text { Number of Creamerymen } \\
\text { using the same per cent } \\
\text { of Acidity .............. }\end{array}$ & 5 & 5 & 16 & 21 & 22 & 22 & 4 & 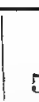 & |Tota1 \\
\hline $\mathrm{r}$ & .45 & & .55 & .60 & $\mid .65$ & .70 & & .80 & $A^{\prime} \mathrm{v}$ \\
\hline
\end{tabular}
1896.

"Fleischmann, W. The Book of the Dairy. Chap. IV. p. 159, Par. 82, 
The average of .62 per cent is about the proper acidity which the starter should have for butter making in the average creamery. Where hand separator cream is used the starter may be ripened to a higher acid than where whole milk cream is used. The greater the extent of undesirable fermentations in cream the higher may the starter be ripened. However, I should not advise ripening the starter higher than .75 per cent.

\section{Regulating the quality of acid in both Starto-} line and starter. When Startoline, due to neglect in handling, produces a low acidity and a sweet flavor in the starter this can be remedied by ripening the Startoline to a higher degree of acidity for several days. Also if the starter is not properly handled and is slow in coagulating, its activity can be increased by ripening the Startoline at a temperature higher than usual and using a larger quantity of Startoline. The slowest Startoline can be made more active by a few days of this treatment. If a starter is too acid in flavor it can be brought back to a mild, pleasant flavor by ripening it to a lower degree of acidity. This is especially noticeable if the starter is cooled to about $56^{\circ} \mathrm{F}$. soon after it is set, before the acidity has developed much, held at this temperature about 5-8 hours and then warmed to about $75^{\circ} \mathrm{F}$. in order to hasten coagulation. On examination at the time of coagulation it will be found that the acid is of a mild, pleasant taste. When this method is used the starter must be used at once, because the high temperature favors 
curdling and wheying off and the possible production of alcoholic fermentations.

78. The pink or brown starter. Heating the starter milk twice to about boiling point has a very detri-. - mental effect on the quality of both the milk sugar and the lactic acid. There are more starters spoiled by overheating the milk than many butter makers imagine. The milk invariably takes on a brownish color when overheated. This indicates that the milk sugar has caramelized by reason of having been scorched. By changing the condition of the sugar, an inferior quality of lactic acid is produced. It is only natural that when the milk sugar is scorched, the starter will have a burnt flavor. This flavor is also imparted to the butter by the use of such a starter and it destroys the fine "bouquet" so desirable in butter. Such a starter is usually spoken of as a pink or brown starter and as having a schorched or burnt flavor.

79. Burnt flavor in starter due to milk used. There is a peculiar flavor in the milk of some herds during the fall, known as a burnt flavor. This peculiarity usually manifests itself more frequently during the corn cutting season than at any other time of the year. This flavor seems to be due to the excessive feeding of corn stalks, corn stubbles, frozen grasses and half dead herbage. Dairymen know that corn eutting knives and the knives of the feed cutter become havily roated with a gummy, sweetish substance from the juices of the corn. This smells a trifle tarry and the same odor can be found in the milk when it flows from the separator or when 
COMMERCIAI, STAR'PERS IN BUTTER MAKING. 61

heated in the starter can. I have known many instances where this flavor was easily noticeable in the starter and also in the butter made from such milk.

80. A starter scoring blank.

Name ............ Date ........... Address .

\begin{tabular}{|c|c|c|}
\hline & $\begin{array}{c}\text { Pelfection } \\
\text { Points }\end{array}$ & Remarlis \\
\hline Aroma & 20 & $\begin{array}{l}\text { Clean, slightly acid, reasonably pro- } \\
\text { nounced, free from taints. }\end{array}$ \\
\hline Flavor & 50 & $\begin{array}{l}\text { Clean, mild acid taste, free from curdy, } \\
\text { cheesy and fermented flarors. }\end{array}$ \\
\hline Body & 30 & $\begin{array}{l}\text { Before breaking up--close, smooth, ino } \\
\text { gas bubbles; after breaking up- } \\
\text { smooth, creany, silky. }\end{array}$ \\
\hline Total & 100 & \\
\hline
\end{tabular}

81. Judging starters. The same scale of points applies to the judging of the starter and of the Startoline. Also in nearly every case the defects found in one will be found in the other. The Startoline should sour in a reasonable length of time if so intended by the person in charge of it. The body should be smooth and firm when well coagulated and it should be free from gas bubbles and whey. When shaken up and poured it should resemble the consistency of well ripened cream and should be smooth and free from lumps and granulations. The aroma should be 
of a clean, pure, acid nature, and be reasonably pronounced. The flavor should be clean and without cheesy or curdy taints. When broken up by shaking and held at a low temperature it should not whey off very soon. Wheying off readily, indicates the weakening of the lactic acid organisms, and the appearance of flat, weak or dull flavors. When such a condition arises a new culture must be set at once, since the starter shows signs of "running out" and may at any time fail to produce a good flavored acid.

-82. Use glassware. Whenever obtainable, glassware should be used in growing the Startoline, because when glassware is clcaned and sterilized it may be stoppered and left for a day or longer without acquiring a bad odor. The only smell which manifests itself upon opening a glass vessel which has been closed for some time is a dead-air smell. This is not the case with a tin vessel, for no matter how carefully cleaned and sterilized it may be, if it is closed tightly for several hours a very offensive odor is noticeable upon opening it. This odor somewhat resembles fermented milk or an old tin can. Due to contamination from this source all tinware used for growing the Startoline should be discarded and replaced by glass vessels. A few glass, quart or gallon jars with glass stoppers, in addition to the utensils already at hand, are all that are needed for handling the Startoline. Glass jars can very easily be sterilized either by boiling them for five minutes or by applying live steam to them by placing them under a pail turned over a steam jet. Glassware 
COMMERCIAL STARIERS 1N BUTPER MAKING. 63

should be used in handling the Startoline whether it be in a large or a small creamery. Where large quantities of Startoline are required use several gallon jars with glass stoppers.

83. Utensils which should not be used. China ware should not be used because the glazed surface cracks very casily and the vessel will absorb milk which will create offensive odors and contaminate the Startoline. Earthenware, such as crocks of any type, should not be used as they are worse than china ware. Either china or earthenware can be used only for a short time, if necessary to use them at all, and they must be thoroughly cleaned and aerated before each time they are used.

High grade enameled ware is very good and may be classed next to glassware for use in the handling of Startoline. Alumium utensils are now being used in some creameries and promise to be among the best utensils for handling Startoline.

Utensils in the order of their usefulness :

1. Glass. 2. Enameled ware: 3. Aluminum ware. 4. High grade china. 5. Tinware. 6. Earthenware.

84. Keep flies from the milk. We need hardly mention what a nuisance flies are around creameries and cheese factories, for this is well known. In order that we may more fully comprehend the importance of keeping the flies from falling into the milk or getting at the same for refreshment, we wish to call attention to some experiments carried on by Prof. F. C. Harrison of Ontario Agricultural 
College as given in Bulletin No. 41, in which he says: "Single flies were placed in test tubes containing a measured quantity of sterilized water and well shaken. This water on analysis was found to contain large numbers of gas producing bacteria. Frequently 50,000 bacteria were obtained from a single fly and of these over 20,000 were gas producing." Is it any wonder that the Startoline or starter does not always turn out as well as it should? I wish to (mphasize the fact that it is not the pure culture that produces gas in starters, but the milk that was used which may have been rontaminated by uncleanly handling, or by imperfect pasteurization. Instances are known where the starter milk after pasteurization and cooling to $80^{\circ} \mathrm{F}$. has risen up and crowded out of the starter can and the gassy curd fell onto the floor beside the starter can. This was due to gassy fermentation and these fermentations are very destructive to the finer flavors in butter or cheese. No high scoring butter can be made from cream in which gassy fermentations are present in any great degree.

85. Starters in cream ripening. It has been found by both scientific men and practical dairymen that natural ripening of cream favors the development of undesirable flavors, unless the cream so ripened was produced and handled under the best sanitary conditions. Ideal sanitary conditions on dairy farms and in creameries do not as a rule now exist. Therefore in order that erearn may be more uniformly ripened from day to day regardless of external con- 
ditions and minor contaminations, a pure lactic ferment culture has been found indispensable in the controlling of undesirable fermentations in cream.

H. W. Conn, in Practical Dairy Bacteriology, says: "The use of starters has frequently been found valuable in avoiding undesirable taints and tastes in butter. These unpleasant flavors which in even the best creameries occur occasionally, can frequently be checked or remedied by the use of a. considerable quantity of a proper starter." He also says: "The acid which they (lactic acid bacteria) develop seems to be injurious to other species and these rapidly disappear as the lactic organisms increase in numbers. As a rule, therefore, milk which sours at about $70^{\circ} \mathrm{F}$. will be found to contain nearly a pure culture of a common lactic acid type. the other organisms, that were so abundant at the outset having disappeared."

86. Raw or pasteurized cream. Starters should be used in both raw and pasteurized cream, but it is only in pasteurized cream that the full benefit of a starter is realized, because in this cream lactic acid can develop without the interferance of other fermentations. 'In raw cream, as a rule, a great variety of other fermentations thrive and therefore the full benefit of the starter is not always realized. Lactic acid develops faster in pasteurized than in unpasteurized cream. The poorer the cream is in quality the larger should be the quantity of starter added to it. 
87. Per cent of starter to be added to cream. The per cent of starter necessary to be added to cream depends upon: (1) the quality of the cream; (2) the richness of the cream; (3) the kind of cream. whether whole milk or hand separator cream; (4) the temperature of the cream during ripening; (5) how long the cream is to ripen until the necessary acid has developed. In the order as mentioned above: (1) when the cream is impure add more - starter; (2) the richer the cream the larger the per cent of starter should be added; (3) hand separator cream as a rule needs more starter than whole milk cream; (4) the higher the temperature of the cream the smaller is the per cent of starter to be added, and the lower the temperature of the cream the larger is the per cent of starter to be used in order that the cream may ripen in the allotted time; (5) the longer the time allowed for the cream to ripen the smaller is the per cent of starter necessary to use and the shorter the ripening period the larger must be the per cent of starter used.

88. Richness of cream and per cent of starter. The following table shows the number of pounds of starter that may be added to cream containing a given per cent of butter fat and still have cream of churnable richness: 
TABLE III.

Per C'cut of starter, Added to Cremit.

\begin{tabular}{|c|c|c|}
\hline $\begin{array}{l}\text { Test of } \\
\text { cream befure } \\
\text { add. starter }\end{array}$ & $\begin{array}{l}\text { Different quantities of } \\
\text { starter added to every } \\
100 \mathrm{lbs} \text { cream }\end{array}$ & $\begin{array}{l}\text { Test of Cream after } \\
\text { adding the starter }\end{array}$ \\
\hline (60\% Crenm & \begin{tabular}{|cccc} 
Adding 100 & llos. starter \\
“ & 50 & "6 & " \\
" & 40 & " & "
\end{tabular} & $\begin{array}{l}\text { Test after add. S. } 30 \% \\
\text { " } 4 \\
\text { " }\end{array}$ \\
\hline $50 \%$ Cream & \begin{tabular}{|cccc} 
Adding & 100 & lus. starter \\
، & 50 & " & " \\
" & 30 & " & "
\end{tabular} & \begin{tabular}{cccc}
\multicolumn{3}{c}{ Test aftel add. S. $25 \%$} \\
" " " \\
" & " & & $33 \%$ \\
& & & $38 \%+$
\end{tabular} \\
\hline $45 \%$ Cream & $\begin{array}{cccc}\text { Adding } & 75 & \text { los. starter } \\
4 & 50 & \text {.. } & \text { " } \\
\text { " } & 95 & \text { " } & \text { " }\end{array}$ & 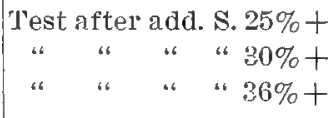 \\
\hline $40 \%$ Cream & $\left\{\begin{array}{ccc}\text { Adding } & 75 \text { lbs. starter } \\
. . & 50 \text { ". } & \text { ". } \\
. . & 25 & \text { ". }\end{array}\right.$ & \begin{tabular}{|cccc} 
Test after add. & s. $23 \%+$ \\
" & " & " & " $26 \%+$ \\
" & " & " & " $32 \%$
\end{tabular} \\
\hline :5\% Cleam & $\begin{array}{cccc}\text { Adding } & 50 & \text { lbs. starter } \\
. " & 40 & \text { " } & \text { " } \\
. & 20 & \text { " } & \text { " }\end{array}$ & $\begin{array}{cccc}\text { Test after add. } \mathbf{s} .23 \%+ \\
\text { " } & \text { ". } & \text { " } & \text { " } 25 \% \\
\text { " } & \text { " } & \text { " } & \text { " } 20 \%+\end{array}$ \\
\hline$\therefore 0 \%$ Cream & $\begin{array}{cccc}\text { Addiug } & 30 \text { lbs. starter } \\
\text { “ } & 25 & \text { “ } & \text { " } \\
\text { “ } & 20 & \text { " } & \text { " }\end{array}$ & $\begin{array}{cccc}\text { Test aftel add. S. } 2: 3 \%+ \\
\text { " } & \text { " } & \text { " } & 24 \% \\
\text { " } & \text { ". } & \text { " } 25 \%\end{array}$ \\
\hline $25 \%$ Cream & $\begin{array}{ccc}\text { Adding } & 20 \text { lbs, starter } \\
\text { ، } & 15 \text { " } & \text { " } \\
\text { " } & 10 \text { " } & \text { " }\end{array}$ & 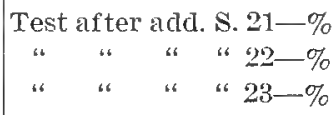 \\
\hline
\end{tabular}


89. Temperature and time in ripening cream. The best temperature for ripening cream at the average creamery is $67-69^{\circ} \mathrm{F}$. in summer and $68-71^{\circ}$ F. in winter. Where a large per cent of starter is used in cream lower temperatures may be used than when small quantities of starter are added. Due to these and other variations previously mentioned no definite length of time can be given in which to ripen cream. Considering the possible action of lactic acid and other fermentations on butter fat during the ripening period it seems that the shorter the period consumed in ripening cream the better is the quality of the butter. Try to adjust things so as not to ripen cream for a longer period than eight hours nor for a shorter period than three hours.

90. A few things to remember. Remember that the lactic acid germ is a tiny, delicate plant.

That heat may very easily destroy its life.

That cold does it no injury whatever.

That high acid weakens and finally kills it.

That a temperature between $65-75^{\circ} \mathrm{F}$. is most favorable for the production of a good quality of acid.

Always use a thermometer when setting tho starter.

Never pasteurize without lknowing the time and temperature applied.

Never use old, acid or unclean milk.

Never use anything but glassware or enameled ware for handling your Startoline. 
COMMERCIAL STARTERS IN BUTTER MAKING. 69

Try to be a good judge of conditions as they arise.

Have a well tinned starter can. Copper is poison to the good flavor of lactic acid, and retards its development. Pay proper attention to the details of the handling of the Startoline and a good quality of lactic acid will be the result.

Do not think that the starter will take care of itself.

Do not think that any kind of sweet milk is good for making a first-class starter. 


\section{CHAPTER VI.}

\section{CREAM RIPENING.}

By the ripening process is meant all the treatment which the cream receives from the time it is separated from the milk until it is put into the churn.

-HENRY H. WING. 


\section{INDEX TO CHAPTER VI.}

Par.No.

Page.

91. The process of cream ripening............ 72

92. Amount of acidity necessary............. 72

93. Scientists believe in cream ripening......... 72

94. Fundamental principles involved .......... 73

95. Physical condition of cream.............. 73

96. Results sought for in cream ripening......... 74

97. Natural ripening of cream............. 74

98. Artificial ripening of cream............. 74

99. Evil effects of high acid in cream.......... 75

100. Ripening temperature of cream............ 76

101. Slow against fast ripening of cream......... 76

102. How to preserve the quality of lactic acid...... 77

103. Acidity in relation to the per cent of fat....... 77

104. How high first class sweet cream may be ripened 78

105. How to find terms used in Table IV......... 79

106. Relative acidity in relation to fat test........ 79

107. Diagram showing degree of acidity......... 81

108. Reports from fifty-six creameries........... 81

109. Ripening mixed sweet and sour cream....... 82

110. Using large or small starter in cream........ 82

111. Ripening hand separator cream........... 83

112. Ripening pasteurized sweet cream.......... 84

113. A new method in cream ripening.......... 84 


\section{CHAPTER VI.}

\section{Cream Ripening.}

91. The process of cream ripening should receive most careful consideration, as much depends upon its being properly performed. The commercial value of butter can be materially reduced by the improper ripening of the eream from which it is made.

92. The amount of acidity necessary in cream at the time of churning depends more upon the condition of the cream at the beginning of the ripening process, than upon any other one factor. The degree and quality of acidity at churning time determines to a great extent the flavor, body and grain of the butter when manufactured. The amount of starter to add to any cream depends upon the richness of the cream and the methods employed in handling it. The higher the acidity and the longer the cream has been held sour after a certain per cent of acidity has been developed, the sooner will the butter made from it lose its fine flavor.

93. Ever since the introduction of butter making, even in its most primitive stage, the majority of practical creamerymen and dairy scientists have held the opinion that properly ripened cream produces butter of better keeping quality than does unripened cream. It has also been found that soured cream has a greater churnability than sweet cream, due in part to the reduction of viscosity and possibly to other changes of which we are wholly or partly 
uninformed as yet. Undesirable fermentations are supposed to be retarded in cream and a process of purification established by the development of pure lactic acid fermentation in cream.

94. Fundamental principles involved. Cream ripening is a process of handling cream by which lactic acid fermentation is allowed to develop to a degree suitable to the American standard for sour cream butter. This fermentation may be the result of the natural ripening of cream or it may be brought about by the introduction of a pure lactic acid culture. The process called natural ripening of cream is gradually giving place to the artificial ripening of cream by means of the addition of a pure lactic ferment culture. The principles involved in the ripening of cream are the same now as they ever were. There is a difference in the methods used which is the result of study of the science and art of practical butter-malising.

95. The physical condition of cream is changed by the process of ripening. Sweet cream is smooth, thin, and of a velvety nature, unless very rich, while soured or ripened cream of the same richness as unripened cream, is much thicker and its flavor is rather coarse. The casein in sweet cream cannot be seen with the naked eye while in soured cream it is coagulated into fine particles by the action of lactic acid. During the souring process the color of the cream changes from a more or less yellowish tint to a whitish shade with a peculiar shiny or glossy surface. 
96. The results sought for in the ripening of cream are: To develop a definite flavor in the butter fat which is so much desired by the average American consumer, to lessen the viscosity of the cream and thereby increase its churnability and decrease losses in the buttermilk, to purify the cream, retard abnormal fermentations and increase the keeping quality of the butter as well as to make possible the manufacture of a more uniform quality of butter by ripening the cream to the same degree of acidity from day to day.

97. Natural ripening of cream. By natural ripening of cream we understand that cream is soured without the addition of sour milk, buttermilk or any pure lactic acid culture. Since cream may contain a large number of different undesirable germs which may develop off flavors and gain the ascendency over the influence of lactic acid fermentations the natural ripening of cream is not always desirable. This is the reason that hand separator cream is so variable in its flavor. If instead of allowing it to sour naturally a good, pure, lactic acid starter were added to the cream the flavor of it would be much improved.

98. Artificial ripening of cream. It is only during the last decade that artificial ripening of cream has become general and the process is looked upon by dairymen as being indispensable in the manufacture of first-class American creamery butter. The only difference between natural and artificial cream ripening is that in the latter a certain per cent of soured milk or cream ripened with a pure lactic 
ferment culture is added to the sweet cream and the cream allowed to sour at regular ripening temperature. This system is considered much superior to the natural ripening process and as a rule much better results are obtained by its use. Undesirable fermentations can be controlled and a more uniform product can be obtained. Coarse flavors can be partly eliminated and butter of finer and more delicate flavor can be manufactured. Since agreeable flavors in butter have a high commercial value it is absolutely necessary that a controlling factor be used every day in the year to insure a reasonably fine, pure and delicate flavor in butter. This can be accomplished in no better way than by the judicious use of a pure lactic ferment culture in the cream to be manufactured into butter.

99. Evil effect of high acid in cream. It is well known that when a certain per cent of acid has developed in cream the lactic acid undergoes a perceptible change easily recognized by taste or smell, or by the appearance of the cream. Lactic acid in whole or skimmed milk has reached its finest flavor when it has developed about .65-.75 per cent acidity, and in cream when about $.55-.65$ per cent acidity is reached. High acid in cream seems to favor the development of oily, sour, bitter, rancid, acid and coarse flavors in butter. It also impairs its keeping quality and reduces its market value besides destroying the fine flavor and aroma belonging to properly ripened good cream. Cream should be ripened to a degree of acidity which conforms to the methods in use for the handling of it, that is-the 
kind of ripener used and the refrigerating or cooling system employed. Whatever system is used the cream should be handled in such a way as to guard against too high acidity at the time of churning.

100. Ripening temperature of cream. The season of the year, the ripeners used, the per cent of starter added and the skill of the operator determine to some extent the temperature at which cream can be ripened. Therefore the temperatures which are used in ripening cream vary from $67^{\circ} \mathrm{F}$. to $72^{\circ} \mathrm{F}$. in winter and from $64^{\circ} \mathrm{F}$. to $69^{\circ} \mathrm{F}$. in summer. If cream were always of the same acidity, age, purity and richness at the time of adding the starter, fewer variations in ripening temperatures would be necessary. Too high ripening temperatures have a tendency to produce oily and weak-bodied butter, while too low temperatures favor the development of old, flat and bitter flavors.

101. Slow against fast ripening of cream. The fundamental principle involved in the ripening of cream is to develop a given per cent of acidity at a temperature which will favor the production of a fine quality of lactic acid. The temperature best suited to this seems to be between $65^{\circ} \mathrm{F}$. and $72^{\circ} \mathrm{F}$. Lactic acid will develop at a higher and also at a lower temperature than that given above, but the desired flavor is not produced at a much lower or much higher temperature. As a general rule fast ripening of cream is preferred for the reason that quick ripening usually favors the production of finer and milder flavored acid. It also helps to prevent the development of undesirable flavors in cream 
during the ripening period which is one of the most critical periods in the handling of cream. Quick ripening of cream is as a rule associated with the use of a large per cent of starter of high quality together with proper temperatures. On the other hand slow ripening of eream whether intentional or otherwise is associated with the employment of low temperatures and the use of a small amount of starter or a starter of poor quality. The result usually is that cream ripened in this way will develop sour, flat, slightly bitter and other undesirable flavors.

102. How to preserve the quality of lactic acid in cream. When cream is ripe-that is when enough acidity has developed, it should be cooled at once to a temperature low enough to prevent the development of acidity to any appreciable extent before churning. By cooling cream when ripe to $50^{\circ} \mathrm{F}$. or lower the lactic acid can be preserved in good cordition for about fourteen hours. Cool cream low enough to render the various fermentations inactive and the quality of the lactic acid will be preserved.

103. Acidity in relation to the per cent of fat in cream. Since the development of lactic acid takes place only in the serum of cream and the per cent of serum varies in relation to the variations in the fat content, it seems but reasonable that the acidity in cream ought to vary in relation to the per cent of fat in cream. The lower the per cent of butter fat in cream the more serum it contains and the higher the per cent of butter fat in cream the less serum it contains. The per cent of serum in cream varies inversely as the per' cent of fat varies, and the lactic 
acid necessary in cream is influenced by the variation of the per cent of fat and the per cent of serum in the cream. The per cent of lactic acid to which cream of varying richnesss should be ripened will be found in table No. IV on page 80.

104. A first class sweet cream testing 30 per cent fat may be ripened to .60 per cent acidity without injuring the flavor, aroma or keeping quality of the butter. But whenever cream is a day or two old and has developed some acidity before arriving at the factory the ripening must not be so high as with good sweet cream. It has been found from practical experience that it is much better to vary the acidity in cream in relation to its fat content than to ripen all cream alike. Due to the difference in the test of various creams and to a slight change in the market in demanding milder acid flavored butter, it was found that a table which would serve as a guide would be useful to the creamery operator. The relative acidity table on page 80 is a mathcmatiral calculation based upon practical experience and gives the acidity of cream in relation to its fat rontent. The working basis on which this table is based and which is considered by practical creamrrymen as the proper per cent of acidity in (ream, is, that cream testing 25 per cent butter fat be riprned to .60 per cent acidity. This is taken as a standard and is based upon sweet cream ripened to .60 por cent and is not based upon mixed cream of various ages and degrees of acidity. The latter kind of cream should be handled differently and we find in the column of mixed cream the per cent of acidity to which such 
cream may be ripened. This difference in the per cent of acidity is made because when part of a batch of cream has been sour for some time before it is mixed with sweet cream and the whole batch after mixing is ripened to the same per cent of acidity to which sweet cream may be ripened without injury, the partly soured cream after being mixed with the sweet cream will easily show the effects of over ripening. This impajrs the kecping quality of the butter and for this reason less acidity in such cream is recommended at the time of churning.

105. How to find terms used in table No. IV. Per cent of butter fat in cream-By Babcock test. Per cent of serum in cream-100 lbs. cream minus fat test. Factor .008 in relative acidity table-per cent acidity $\div(100$ - per cent fat $)=.008$ per cent of acidity in one per cent of serum.

Relative acidity $=(100$ - per cent fat in cream $) \times$ $(.008 \div 100)=$ acidity.

Problem: Standard. Cream testing 25 per cent butter fat ripened to .60 per cent acidity.

Formula: Acidity $=.008 \times(100-25 \div 100)-.60$ per cent.

106. Table of relative acidity in cream in relation to the per cent of butter fat, from 20 per cent to 40 per cent.

The following table will serve to give an idea of the acidity to which eream of different richness may be ripened in order that it may have the same density or strength of acidity. However, cream may be ripened a little higher or lower in acidity than given in the table without materially injuring the flavor or keeping quality of the butter. Therefore, it must be understood that this table will not serve as a hard and fast rule in the ripening of cream. No 
one can lay down a rule for ripening cream which answers all conditions. Every butter maker in his own creamery and locality, must to some extent solve these problems in connection with the handling and ripening of cream for himself. Although this is the case, a standard may be useful in order to enable the butter maker to have better control of the situation. The ripening of cream to a higher or lower per cent of acidity than that proposed in the standard is influenced by the condition, age, acidity of cream before ripening, and the extent of abnormal fermentations present in the cream.

TABLE IV.

Table of Relative Acidity in Cream in Relation to the Per Cent of Butter Fat, From $20 \%$ to $40 \%$. Standard Cream Test $25 \%$, Acidity .60\%.

\begin{tabular}{|c|c|c|c|c|}
\hline $\begin{array}{l}\text { Per cent of } \\
\text { Butter fat in } \\
\text { Cream }\end{array}$ & $\begin{array}{l}\text { Per cent of } \\
\text { Serum in } \\
\text { Cresm }\end{array}$ & $\begin{array}{l}\text { Per cent of } \\
\text { Aclaity in } 1 \% \\
\text { of Serum }\end{array}$ & $\begin{array}{l}\text { Relative } \\
\text { Acldity of } \\
\text { Cresm }\end{array}$ & $\begin{array}{c}\text { Relative } \\
\text { Acldity of } \\
\text { Mixel Cream }\end{array}$ \\
\hline $20 \%$ & $80 \%$ & .008 & $.64 \%$ & $.60 \%$ \\
\hline $21 \%$ & $79 \%$ & .008 & $.63 \%$ & $.59 \%$ \\
\hline $22 \%$ & $78 \%$ & .008 & $.62 \%$ & $.58 \%$ \\
\hline $23 \%$ & $77 \%$ & .008 & $.61 \%$ & $.56 \%$ \\
\hline $24 \%$ & $76 \%$ & .008 & $.60 \%$ & $.55 \%$ \\
\hline $25 \%$ & $75 \%$ & .008 & $.60 \%$ & $.54 \%$ \\
\hline $26 \%$ & $74 \%$ & .008 & $.59 \%$ & $.53 \%$ \\
\hline $27 \%$ & $73 \%$ & .008 & $.58 \%$ & $.52 \%$ \\
\hline $28 \%$ & $73 \%$ & .008 & $.57 \%$ & $.51 \%$ \\
\hline $29 \%$ & $71 \%$ & .008 & $.56 \%$ & $.50 \%$ \\
\hline $30 \%$ & $70 \%$ & .008 & $.56 \%$ & $.49 \%$ \\
\hline $31 \%$ & $69 \%$ & .008 & $.56 \%$ & $.48 \%$ \\
\hline $32 \%$ & $68 \%$ & .008 & $.54 \%$ & $.47 \%$ \\
\hline $33 \%$ & $67 \%$ & .008 & $.53 \%$ & $.46 \%$ \\
\hline $34 \%$ & $66 \%$ & .008 & $.52 \%$ & $.45 \%$ \\
\hline $35 \%$ & $65 \%$ & .008 & $.52 \%$ & $.45 \%$ \\
\hline $36 \%$ & $64 \%$ & .008 & $.51 \%$ & $.45 \%$ \\
\hline $37 \%$ & $63 \%$ & $.008^{\circ}$ & $.50 \%$ & $.45 \%$ \\
\hline $38 \%$ & $62 \%$ & .008 & $.49 \%$ & $.45 \%$ \\
\hline $39 \%$ & $61 \%$ & .008 & $.48 \%$ & $.45 \%$ \\
\hline $40 \%$ & $60 \%$ & .008 & $.48 \%$ & $.45 \%$ \\
\hline
\end{tabular}


Prof. Spillman, of Washington State, Expt. Sta., in bulletin No. 24 says: "The acidity of cream when ready to churn is usually between .50 per cent and .70 per cent. If the acidity be lower than .50 per cent the butter will lack flavor and there is liable to be a great loss of fat in the buttermilk. If above .70 per cent the butter may have undesirable flavors."

107. Diagrams showing the different degree of acidity to which cream having a high per cent of fat and cream having a low per cent of fat may be ripened.

\begin{tabular}{|cc|}
\hline $20 \%$ & Fat \\
\hline Acidity & $.64 \%$ \\
Serum & $80 \%$ \\
\hline
\end{tabular}

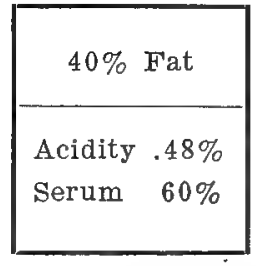

The above diagrams show to what acidity cream should be ripened and more fully explains the value of the preceding relative acidity table. Suppose both lots of cream were ripened to .50 per cent acidity; the cream containing 40 per cent fat would be ripened about right, while the cream containing 20 per cent fat would not have sufficient acidity. For the production of the finest and fullest flavored butter, cream should test about 25-30 per cent fat after the starter has been added. Butter made from cream testing above 33.per cent fat, very easily develops oily, greasy and slightly flat flavors.

108. In visiting thousands of creameries in ten of the foremost dairy states in the United States, I 
have found that the average acidity to which whole milk cream was ripened was about .55 to .64 per cent and the acidity to which hand separator cream was ripened was about .50 to .55 per cent. This agrees with my own experience in practical creamery butter making. Ovier-ripening is the cause of much of the poor butter now on the market, and it should be guarded against.

109. Ripening mixed sweet and sour cream. Better results can be obtained by ripening mixed cream faster than if it were all sweet. This can be accomplished by adding a heavy starter-not by raising the ripening temperature in order to hasten the ripening process. Mixed sweet and sour cream easily develop coarse flavors and for this reason high ripening or over-ripening must be guarded against. Pasteurizing such cream lessens the danger of the development of coarse flavors and when it is pasteurized the ripening process can be carried on in about the same way as if it were all sweet cream. Mixed cream especially when tainted is very much improved by pasteurization and by frequent stirring during ripening.

110. Using large or small starter in cream. When all other conditions are right the larger the per cent of starter added to cream the faster it will ripen. The ripening temperature must be lower than when a small starter is used and the cream must be cooled before it has reached the desired acidity in order to prevent its becoming over-ripe and to guard against acid flavors and coarse aroma in the butter. On the other hand the smaller the 
per cent of starter added the higher must be the teinperature of the eream and the slower will the ripening process be. The longer it takes to ripen cream the more danger there is of developing off flavors and producing butter which is flat, slightly bitter and coarse flavored. Adding a very heavy starter (over 40 per cent) to eream has a tendrney to impart a starter flavor to the butter if the cream to which it is added is ripened at normal ripening temperatures and not cooled to a sufficiently low temperature after ripening.

111. Ripening hand separator cream. Unpasteurized hand separator cream. Gathered or hand separator cream must ba handled differently after it has reached the factory than the whole milk cream is handled. It must be handled according to its qua]ity-that is, according to the per cent of acid and the degree of abnormal fermentation it contains. There are several different methods of handling this cream in use at present. Some creamerymen advise ripening and handling it in the same manner as whole milk cream, while others prefer an entirely different system. Some of the latter advocate not warming it to ripening temperatures. They advise cooling the cream to below ripening temperature when received and holding at this temperature until it is ready to be churned. The reason for not ripening such cream at normal temperatures is that the average quality of hand separator cream has a high degree of acidity and contains a variety of abnormal fermentations at the time it is received at the factory. If it were heated to ripening temperatures 
the abnormal fermentations present in it would immediately increase and their development could not be checked nor controlled even by the use of a pure culture starter. Therefore it is much more desirable to add as much starter as the richness of the cream will allow and keep the cream cold for three hours or more before churning.

112. Ripening pasteurized sweet cream. Experience has laught us that the ripening of either pasteurized sweet hand separator cream or whole milk cream should be handled differently than sour raw cream, whether it is hand separator cream or whole milk cream. Pasteurized sweet hand separator cream should be ripened the same as sweet whole milk cream (Page 78). After cream is pasteurized it should be cooled at once to ripening temperature -between $64^{\circ} \mathrm{F}$, and $72^{\circ} \mathrm{F}$. according to the season of the year. The starter should then be added and the cream stirred frequently until about .50 per cent to .55 per cent acidity has developed. It should then be cooled at once to a temperature low enough to keep the lactic acid in the cream in perfect condition until churning time.

113. A new method which has been tried with good results with reasonably rich cream is to add a very heavy starter (about 35 per eent or more), cool the cream immediately to $52^{\circ} \mathrm{F}$. or lower and hold at that temperature for eight to fourteen hours before churning. This method of adding a heavy starter whenever the richness of the cream permits is gaining in favor in some of the best creameries. It not only seems to produce as fine butter as that made by the other system but it lessens the labor incident to cream ripening. 


\section{CHAPTER VII.}

\section{THE CHURNING OF CREAM}

Experience shows that oily butter is obtained by too quick as well as too slow churning.

W. FLEISCHMANN. 


\section{INDEX TO CHAPTER VII.}

I'ar. No.

Page.

114. When butter is perfect in body........... 87

115. Chumbility of cream ............... 87

116. Churning temperatures $\ldots \ldots \ldots \ldots \ldots \ldots \ldots \ldots .88$

117. Conditions affecting chuming temperatures..... 88

118. 'l'est of cream affecting churning temperatures... 8?

119. Quntity of cream in churn............ 89

120. Age of cream $\ldots \ldots \ldots \ldots \ldots \ldots \ldots \ldots \ldots \ldots \ldots .90$

121. Temperature of churuing room........... 92

12.2. Range of temperatures $\ldots \ldots \ldots \ldots \ldots \ldots \ldots \ldots . .93$

12:3. Ifolding cream before churning........... 9t

124. Tenperature and time ............... 95

125. Acidity of crenm .................. 95

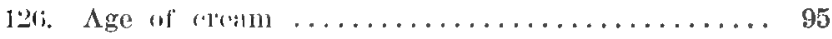

127. Loss itl buttermilk dne to rich cream........ 95

12x. Quantity of ream in churn.............. 96

129. Speer of churn $\ldots \ldots \ldots \ldots \ldots \ldots \ldots \ldots \ldots \ldots \ldots$ 97

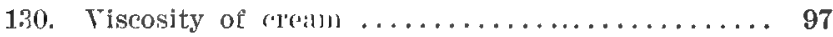

131. What to do with a difficult churning......... 98

132. Danger of too long churning............ 98 


\section{CHAPTER VII. \\ The Churning of Cream.}

114. Whenever butter is found to be perfect in body and grain, it can be depended upon that the churning of the cream was properly performed. Improper methods in the process of churning are followed by faults in the body of the butter. The manner of churning, as well as the shape and size of the butter granules, affects the aroma and flavor of the butter. Conditions in cream which, during churning, interfere with the formation of perfect granules of butter, must necessarily affect the granular structure and the grain of butter. The more defined and ragged the butter granules are, the greater is the volumn of aroma, and the more delicate is the flavor.

115. Churnability of cream. In farm dairy practice the churnability of cream is affected by more factors than is the churnability of cream in cream. eries. This may be due in part to the fact that cream churned on the farm is usually from one herd of cows while the cream that is churned in a creamery is from the milk of a number of different herds all put together in one vat and mixed before it is churned. By mixing the cream, the different batches of cream lose their individual characteristics and are made more uniform. The main factors which seem to affect the churnability of cream are temperatures and ripeness of cream and seasons of the year. 
116. Churning temperatures. The temperature for churning which is indicated on dairy thermometers seems to be the result of a custom based perhaps on the practice prevailing in farm dairies years ago, of using this temperature for churning. The conditions and methods of handling cream may have been such a few decades ago, as to warrant the churning of eream at or near $62^{\circ} \mathrm{F}$. At present if one were to make a hard and fast rule for this (which by the way is impossible) a temperature of $56^{\circ} \mathrm{F}$. would be more likely to be practicable in the average creamery. Since the introduction of modern dairy machinery and the increased circulation of dairy literature, dairying in general has undergone a complete change. In former times when cream was raised by the gravity system and then dipped off the milk, a comparatively large quantity of milk went in with the cream and consequently such cream had to be churned at a comparatively high temperature. Under such conditions $62^{\circ} \mathrm{F}$. was probably the proper churning temperature. Why manufacturers of thermometers still continue to indicate churning temperature as being $62^{\circ} \mathrm{F}$. is a mystery and it is undoubtedly misleading to the novice in dairying.

117. The churning temperature of cream concerns every butter maker and the failure to properly adjust the temperature according to the richness of the cream, quantity of cream in the churn, age of the cream, acidity of the cream, scason of the year, room temperature and the length of time the cream has been held at a low temperature, etc., will not 
give the best results. Even if the churning temperature were not affected by so many different conditions it would not be safe to lay down a hard and fast rule regarding ehurning temperature. Conditions in creameries and the ability of the individual in charge of the handling of the cream play an important part in determining what this temperature must be.

118. The butter fat content of cream is the main factor in determining at what temperature cream shall be churned. When cream is very rich, testing perhaps 33 per cent butter fat, it must be churned at a low temperature in order that good results may be obtained. Such cream can be churned at a temperature as low as $43^{\circ} \mathrm{F}$. in summer. Very thin eream, testing perhaps 20 per cent, must be churned at a rather high temperature, especially when the churn is full or overloaded. There is a great difference in the closeness of the fat globules in rich and in poor cream. Reing very much closer in rich cream they come in closer contact when the cream is agitated and strike each other more frequently during the churning process than do the globules in thin cream. There is so much serum mixed with the thin cream that it is difficult for the fat globules to strike each other hard enough to cause them to adhere to each other and gather during the churning process. It is therefore evident that the churning temperature must be higher for thin cream than for cream which is rich in butter fat.

119. The observant operator must have noticed that the time required for churning in influenced by 
the quantity of cream in the churn and that the condition of the butter granules at the end of churning is influenced in the same way. For example, take a churn having a capacity of 1,500 pounds when a little over one half full. This quantity of cream testing 30 per cent butter fat may churn exactly right at a temperature of $55^{\circ} \mathrm{F}$., while if we reduce the quantity to $600 \mathrm{lbs}$. and maintain the same test and temperature it will churn too quickly and may cause a heavy loss in the buttermilk. Now, suppose we take 600 pounds of cream testing 22 per cent butter fat. We can churn this cream in the same churn very nicely at a temperature of $56^{\circ} \mathrm{F}$., but if we had 1,500 pounds if this 22 per cent cream and churned at a temperature of $56^{\circ} \mathrm{F}$., the chances are that it would take about two hours or more to churn it; especially if the churning room were so cold that the temperature of the cream would not be raised during the churning process. These variations in temperatures in relation to the quantity of cream in the churn may be explained in the following manner: When the quantity of cream in the churn is small, a fat globule may strike or gather several other globules at every revolution of the churn; but when the churn is too full of cream, one fat globule may strike or gather only one fat globule at each revolution, due to less violent agitation. Therefore, it can be easily seen that when the churn is full the temperature must be higher than when it is only one-half or one-fourth full.

120. The age of the cream has quite a marked influence on the churning temperature. As a rule, the 
older the cream, the more quickly it will churn. Fresh cream, ripened only a little and held cold only a short time before churning, seems to require a longer time for churning than older cream does. The fact that there is such a difference in the time required for the churning of old and fresh cream may explain why it is that when old and fresh cream are mixed and churned soon after mixing, the cream will not churn as exhaustively as it should The older the cream, the lower can the temperature be, provided that it has not been held too long at a low temperature previous to churning. However, fresh cream can also be churned at a low temperature and in fact must be so churned, if it is to churn exhaustively. The time required for churning will be longer than that required for older cream. The temperature at which cream has been held previous to churning has a decided influence on the temperature at which it can be churned. When cream has been held for only a few hours at a low temperature it would not be well to churn it at a high temperature. But if cream has been held at a low temperature for a long time (twelve or fourteen hours) it may be warmed to a higher temperature and still churn well and produce firm-bodied butter; but if this same cream were to be churned at a temperature three or four degrees lower than that at which it has been held, it would require hours to churn it. If cream is to be churned shortly after coolingthat is, three or four hours-the temperature must be very much lower than it would need to be if the same cream were to be held for eight, ten or twelve 
hours. It is well to remember that the longer cream has been held at a low temperature the higher can the churning temperature be; and the higher the temperature at which the cream has been held previous to churning, the lower it should be cooled for churning in order to produce firm-bodied butter.

\section{The temperature of the churning room has a} decided influence on the temperature at which cream should be churned. When the churning room is cold, the cream may be put into the churn at a higher temperature than when the room is warm. But if the cream is a little high in temperature in relation to the test and quantity, and the room is somewhat warmer than the cream, the result from this churning will probably not be very satisfactory. The most exhaustive churnings can generally be obtained when the temperature of the churning room is as low, or lower, than that of the eream to be churned, provided that the temperature of the cream has been properly adjusted before putting it into the churn. In regulating the temperature of cream for churning, the season of the year must always be taken into consideration. In the spring the butter fat is likely to be of a softer nature than in the fall and winter. In fall and early winter the cream is likely to be more viscous and may require a little higher temperature than during the spring and summer months. The fat globules are somewhat firmer during the winter months than they are in spring and summer. This is probably due to some exten1, to the kind of food eaten by the cows during 
this season. The advanced stage of lactation in cows has not such a marked influence on the churning temperature in creamery butter making as in farm dairying.

The following table will serve to indicate the approximate temperature at which crearn of different richness may safely be churned. As the seasons of the year have some influcnee on the temperature at which cream should be churned a division is made in the table for the different seasons. The temperatures must be regulated according to creamery conditions and different methods employed by creamery operators.

Seasons of the Year.

\begin{tabular}{c|c|c|c|c}
\hline Cream Tests & $\begin{array}{c}\text { spring } \\
\text { Deg. Fahr. }\end{array}$ & $\begin{array}{c}\text { Summer } \\
\text { Deg. Fahr. }\end{array}$ & $\begin{array}{c}\text { Autumn } \\
\text { Deg. Fahr. }\end{array}$ & $\begin{array}{c}\text { Winter } \\
\text { Deg. Fahr. }\end{array}$ \\
\hline $30 \%$ & $\mathbf{4 8 - 5 3}$ & $\mathbf{4 8 - 5 4}$ & $50-55$ & $51-55$ \\
$28 \%$ & $50-54$ & $50-55$ & $52-56$ & $53-56$ \\
$26 \%$ & $52-55$ & $52-56$ & $53-57$ & $54-57$ \\
$24 \%$ & $53-57$ & $53-58$ & $54-57$ & $55-57$ \\
$22 \%$ & $55-58$ & $55-59$ & $56-60$ & $56-60$ \\
$20 \%$ & $56-59$ & $57-60$ & $58-60$ & $58-60$ \\
$18 \%$ & $58-60$ & $58-60$ & $58-62$ & $58-62$ \\
\hline
\end{tabular}

122. Range of temperature at which cream of different richness may be churned:

These temperatures are influenced by various factors previously explained. That cream can be churned as indicated in the table is due to the different conditions which may and do exist in different creameries. The temperature indicated is the temperature at which cream should be put into the churn and not the temperature at the end of churn- 
ing. The object of the table is to show the variations in tempratures and the lowest and highest temperature at which cream can be churned and still have the butter come in the condition which is desired by creamerymen.

123. Holding cream before churning. It is generally understood among creamerymen that creamcries have individual characteristics as well as individuals have and that we cannot lay down a hard and fast rule to be applied in every creamery. Cream in each creamery must be handled according to the conditions existing there, as well as according to the ability and individuality of the operator. While the method of holding the cream for three hours after it is separated from milk or is delivered and put into the vat is sufficient for good results at one creamery, the same method may result in a fajlure at another creamery. In one creamery the method of ripening cream at ordinary temperatures may give excellent results, while the same method in another creamery may give results exactly the reverse. The degree of acidity in cream must be varied in different creameries in order to produce the same results. In one creamery the cream may be ripened to .65 per cent acidity and in another it may be ripened to .50 per cent or .55 per cent acidity and both produce about the same results. At one creamery the cream may be held over night and churned in the morning with good results, while at another creamery it is necessary to churn the cream in three or four hours after it is put into the vat. At one creamery, cream of a certain test, acidity and age, 
can be churned very successfúlly at a temperature of $56^{\circ} \mathrm{F}$. while cream of the same kind may have to be churned at $52^{\circ} \mathrm{F}$. at another creamery if the same results are to be obtained.

124. Temperature and time. The following are the main factors which influence the time used in churning and they are arranged according to their relative influence:

1. Temperature of cream.

2. Richness of cream.

3. Fullness of the churn.

4. Time cream is held at a given temperature.

5. Season of the year.

6. Ripeness of the cream.

7. Speed of churn.

8. Diameter of churn.

125. Acidity of cream. In a preceding chapter it has been pointed out that the lactic acid has a marked effect on the viscosity of cream. It seems to have a tendency to render the cream less viscous, or more liquid and thereby enables the fat globules to more readily unite in the churning process.

126. Age of cream. Age also seems to have the effect of destroying the viscosity and producing a certain condition in the cream which makes it churn more readily than when it is fresh even at the same degree of acidity. Therefore it would seem that age has a similar effect on the viscosity of cream as lactic acid.

127. From table on page 93, it will be noticed that the richer the cream, the lower must be the 
temperature for churning. Cream testing 35 per cent butter fat will as a rule churn in much less time than cream having only 22 per cent butter fat. The exhaustiveness of churning is also influenced to some extent by the richness of the cream. Very rich cream ( 33 to 36 per cent) when the churn is over half full will very readily adhere to the sides of the churn and will swing round as the churn revolves. Such cream will lose more butter fat in the buttermilk than cream which is not so rich and which through the whole process of churning produces a regular drop. It can readily be seen that a regular and uniform drop of the cream in the churn would have a tendency toward uniting the fat globules uniformly and the loss in butter fat would be relatively less. It seems that when a regular drop is not produced, the globules that are more easily churnable unite in the granules and leave the smaller ones to unite later in the churning process. If these globules fail to unite there would be great loss in the buttermilk. Sometimes when the cream is too rich, part of it will adhere to the inside fixtures of the churn and not readily drop off during churning and will not be churned nor gathered at all. This is a source of considerable loss in the buttermilk.

128. Quantity of cream in the churn. The quantity of cream in the churn bears a definite relation to the time it will take to churn. As a rule the fuller the churn the longer it will take to churn. It is not advisable to fill the churn more than half full due to the fact that there is not sufficiont space in the 
churn for the cream to drop or ereate the necessary concussion. Where the churn is too full and the cream very rich the churn may become nearly full during the churning process, due to the swelling of the cream. This will increase the time of churning and is likely to cause a heavy loss in the buttermilk. The smaller the quantity in the churn the lower should the temperature be and the fuller the churn the higher should be the temperature. If one were to divide the cream in the vat into two quantities and take one part, equal to one-third of a churn full and the other part equal to two-thirds of a churn full and churn both at a temperature of $50^{\circ} \mathrm{F}$. it will be noticed that the difference in churning time will be very marked and that the butter granules in the two churnings will be very different in size and shape.

129. Speed of churn. The churn must not be speeded too high because it then has a tendency to carry the cream around with it and not produce a drop; but on the other hand if the churn goes too slowly the concussion would be so small that churning would be impossible. The churns as they are now put upon the market are as a rule well tested, and it is therefore safe to follow the directions given with them regarding the speed of the churn. In order to determine just what speed gives best results I may mention that it would be a good plan to carefully increase or decrease the speed of the churn and watch results. The speed found to give most desirable results can then be adopted. 
130. Viscosity of cream. During the cold season when it is suspected that viscosity in the cream has been the cause of a difficult churning, the trouble ean to some extent be avoided in subsequent churnings by adding a large per cent of starter and by carefully watching the process of ripening the cream. If the cream is ripened uniformly and to a sufficient degree of acidity, and the temperature of it adjusted according to the per cent of butter fat it contains there will be little trouble with difficult churning. In fact there is really no need of having any trouble in churning.

131. When difficutly is experienced in churning it can nearly always be traced to neglect on the part of the operator to properly adjust one or more of the various conditions affecting the uniting of the fat globules during churning. However, in case one has a difficult churning to deal with, caused for instance by the cream having swelled to such an extent that there is little chanec of making a churning in a reasonable length of time, a good thing to do is to add a little salt--about one per cent-and let the churning proceed for about five or ten minutes. If no difference in the consistency of the eream is noticed at the end of this time, pour in about ten per cent of water having a temperature of $95^{\circ} \mathrm{F}$. The water should be poured in quickly, distributing it as uniformly as possible, and the churn started at once in order not to allow the water to act on a small quantity of the cream and fat globules and soften enough of them to produce greasy butter. If this treatment does not produce the desired effect on the 
cream the next best thing to do is to draw off 'nough cream to allow a perfect drop of the cream rcmaining in the churn.

132. Danger in too much churning. When the butter comes in granules like shot and churning is continued for some time after that stage is reached, for the purpose of producing larger granules, there is danger of the friction of the granules producing salvy and greasy butter. When the butter comes in fine granules and it is difficult to churn the granules to larger size it is well to stop the churning and draw off enough of the buttermilk to produce a greater density of butter fat. The granules of butter drawn off with the buttermilk can be caught on a fine sieve and returned to the churn. By drawing off part of the buttermilk the fat globules come closer together and will more readily unite into larger granules when churning is continued. Cream which ehurns in this way does not produce the finest butter. Anything affecting the structure of butter granules is likely to produce a greasy surface and tends to destroy the fine aroma of the butter. When butter granules are fine, round and hard and churning is continued for some length of time without changing their shape or size, the surface of the granules is rubbed smooth by friction against each other. This breaks the grain and produces greasy butter. The body of the butter as already stated is greatly affected by the granular structure of the butter granules at the end of churning. The ideal condition of the butter granules, is to have them come in ragged or irregular bodies. The more irregular they 
are the more perfect will be the body of the butter. The salvy aud greasy condition so often noticed in butter on the market is due in a great measure to the care of the cream and the manner of churning and not entirely due, as some believe, to the methods of handling the butter after churning.

Heavy losses of butter fat in the buttermilk may be due to improper ripening of the cream, churning at 100 high temperatures, too quick churning, too long churning, churning mixed sour and sweet ('r'am and in fact to anything which effects the idleal conditions of the churning process. 


\section{CHAPTER VIII.}

\section{THE HANDLING OF BUTTER AFTER CHURNING.}




\section{INDEX TO CHAPTER VIII.}

I':tr. No.

T'age.

13:. Irandling of butter after churning. . . . . . . 10.3

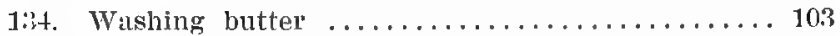

1:35. The effect of over chulning............. 114

1:3. How to handle over (duumed butter.......... 104

137. Add water quickly ................... 105

138. Quantity of wash water to be used.......... 115

130. Working butter . .................. 101;

140. IIow to know when butter is worked enough.... 16i

141. Conditions affecting working of butter........ 16i;

142. Packing butter ................... 107

1-:i. Prepalation of tubs and boxes for packing butier 10

14. Printing butter for market............ 108

145. rosses when butter is sold in bulk.......... I1

14i. Preparing butter printers .............. 108

147. Conclition of butter for moulding........... 100

148. Wrapping lutter .................. 110

14!). Brand on wrapper ................ 110

150. Treating butter tubs or boxes for mould-First

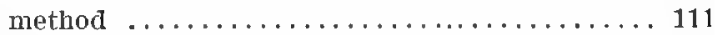

Second method $\ldots \ldots \ldots \ldots \ldots \ldots \ldots \ldots \ldots \ldots \ldots 11$

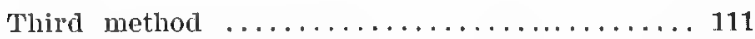

151. Methods of applying palriffine............ 112

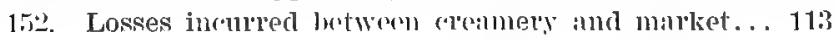




\section{CHAPTER VITI.}

\section{The Handling of Butter After Churning.}

133. As has been stated in a previous chapter, the more ragged the butter granules (provided the eream is of good quality) the finer will be the flavor and the better will be the body of the butter. The finer the granules the more easily is the butter fat affected by temperatures of wash water and the manner of manipulation during washing. The larger the granules are when the butter comes the less quickly will temperatures affect their consistency. Iarge, soft granules and warm wash water are likely to result in mottled butter. Fine, firm granules and cold wash water will usually produce dry butter.

134. Washing butter. The temperature of the wash water may vary a few degrees in relation to the temperature of the buttermilk and still give good results. Fine butter granules when washed with cold water will more easily remain separate than larger granules will when washed with the same temperature of wash water. Washing fine butter granules with cold water will chill and harden them and make the proper working of the butter difficult. It also prevents a perfect dissolving of the salt. We may take it for granted that the finer the granules the less time the butter should be subjected to the same temperature of wash water as is used on granules which are much larger or coarser. The amount 
of washing that butter should receive depends entirely upon the quality of the cream, the condition of the butter when churned and the method of washing used.

135. When butter has come in lumps, that is, when it has been overchurned, the wash water ought not be very warm because using warm water on butter in this condition softens the outside of the lumps and encloses the buttermilk. This usually produces a milky brine in the butter. If quite cold wash water is used on large lumps it causes the outside of the lumps to become firm and cold, thus favoring the production of mottles, unless the water is left long enough on the butter to produce a uniform temperature throughout the entire mass. The quantity of wash water necessary, the temperature to be used and the amount of washing necessary for every churning of butter are problems which the butter maker must study out for himself. The finer the granules, the more quickly will the temperature of the wash water affect their consistency, and therefor the wash water, whether warm or cold, must not be left on the butter long, either to harden or soften it.

136. In case butter is overchurned the following procedure may assist the creamery operator in ridding the butter of undue quantities of buttermilk which is enclosed in the large lumps of butter. Add as much water as cream churned, revolve the churn a few times and draw off the water. Again add the same quantity of water and work butter one revolution at a time, three or four times at intervals of 
five minutes. Draw off the water and drain; then salt and work as usual. Be sure to observe how the butter handles and if it is inclined to be soft (which may mean an excess of moisture) work in the salt at intervals, allowing the butter to stand a short time between workings.

137. Wash water should be put into the churn as quickly as possible to avoid softening or hardening part of the butter. Even when the temperature of the wash water is the same as the temperature of the butter, the running in of the water and the washing and draining of the butter should be quickly done. Most of the fine flavor in butter is supposed to be volatile and it is therefore necessary that the butter should not be subjected to much washing nor allowed to stand in the wash water for any considerable length of time unless the butter contains bad flavors.

138. Quantity of wash water to be used. The larger the quantity of wash water used the more readily will the butter be freed of buttermilk, and the smaller the quantity of wash water used the less effect it has on removing the buttermilk. A small quantity of wash water with butter of average consistency has a tendency toward uniting the butter fat more readily into large lumps. This is conducive to holding moisture in butter.

The amount of churning that is necessary in wash water depends first, upon the condition of the butter and the firmness of the granules, second, upon the temperature of the butter fat, third, upon the amount of water used, and fourth, upon the quality of the butter. 
139. Working butter. The American market prefers a smooth, waxy buttrr, with some salt, and this can only be obtained by working the butter properly with a sufficient amount of moisture and a proper amount of salt. The softer the butter the less it needs to be worked, and the firmer it is the more working it needs in order to give it a smooth body and to properly incorporate the salt. In working butter, be guided mainly by the appearance of it and not by the number of revolutions of the churn.

140. How to know when butter is worked enough. Take a chunk of butter from the churn; cut it with a wire, a string or a ladle. Notice that the cut surface shows a close, smooth, even front. Then take it with two ladles, cut nearly in two and then pull. If the butter is worked enough it will adhere and draw a little before breaking; but if not worked cnough it will break off and show a loose open edge with drops of water of various sizes at the break. In case of leaky butter the edge will be rather ragged and open, due to pockets of water in the, butter. As a general rule butter that is waxy, smooth and close in body is worked enough.

\section{When other conditions are right:}

1. Soft butter needs less working than hard butter.

2. A small quantity more than a large quantity.

3. Well churned butter less working than overchurned butter.

4. Spring and summer butter lesis working than fall and winter butter.

5. Buttur from rram hold over night more 
working than butter from cream churned two or three hours after cooling.

6. The lower eream is cooled and the longer it is held at a low temperature the more the butter must be worked.

142. Packing butter. Cleanliness in handling the butter when packing, and neatness of the package, play an important part in the success of a creamery. A neat package is a good advertisement for a creamery and is a true index to the character of the operator. Butter should be packed immediately after it is worked enough to properly incorporate the salt and before is hardens or "sets." If butter is packed after it has hardened, some of the moisture which has collected in small drops is easily expressed; while if it is packed while soft less moisture is lost.

143. When butter tubs are used place a small quantity of butter in each tub and pack it down well in order that the bottom of the tub will be perfectly filled. Then proceed to fill the tubs. When boxes are used the corners should be well filled in order to exclude the air, and the top should be cut off smoothly. Boxes may be paraffined or parchment lined or both depending upon the demands of the commission house buying the butter. The top may be covered with a paper square and a little salt sprinkled on top. As a rule the top of the butter is cut off smoothly, even with the top of the tub. If a liner is used in the tub, turn the top of it, which usually extends one-half to one inch above the top of the tub, over onto the butter. Now place a cloth circle on top of the butter, sprinkle a layer of salt 
on it and on this place a parchment circle. The salt may be put on the butter either dry or wet, as directed by the dealer.

144. Printing butter for market. The demand for block, printed, or moulded butter is increasing gradually from year to year. This is probably due to the fact that there is less loss connected with the handling of it by the dealer than there is with jar or tub butter and the customer feels that he is getting a full pound and will have no loss by water leaking out as is the case where butter is bought in a jar.

145. When butter is dished out from large packages losses may occur in several ways. There are slight losses in weighing; a little water always leaks out of the butter when it is cut and a little butter always adheres to the packages and utensils used in handling it. When creameries market their butter in prints or blocks no shrinkage can be reported by commission houses, nor can the creamery man claim more butter than he actually markets. This is a very satisfactory way of marketing butter and should be encouraged, provided the market is willing to accept it.

146. Preparing butter printers. When butter is moulded or printed direct from the churn the printer used must be in the best possible condition in order that it may deliver perfect prints. First soak the printer with boiling water applied either with a hose or dipper until the wood is soaked well, then apply cold water in the same way until the

- printer is as cold or colder than the butter. The trays used should be treated in the same way except 
that instead of applying the water with a hose or dipper they may be soaked in a tank.

The printer should be as cold or colder than the butter because when the butter is colder than the printer, the outside of the butter is warmed and becomes sticky. This causes it to adhere to the printing machine. When the butter is warmer than the printer it hardens on the sides touching the machine and in this way retains a perfect mould. Machines used for printing butter, whether table printers or hand moulders, should not dry out much between the times that they are used, as much drying of the wood causes warping and eracking and this makes a perfect mould impossible. When a printer has dried out much it requires the expenditure of considerable time to soak sufficiently.

147. Condition of butter for moulding. Butter used for moulding immediately from the churn should be neither hard nor soft, but just firm. When butter is a trifle soft place a picce of ice in the churn, close the cover and allow it to stand for one or one and one-half hours before moulding and it will then be in proper condition for making good prints. When butter is quite firm mould immediately after the working is finished. If butter hardens too much before printing losses are incurred through the expelling of water during packing.

When butter is moulded or printed directly from the churn it is necessary that great care be taken to have it of the proper firmness; therefore, the temperatures during churning and working must be carefully adjusted. 
148. Wrapping butter. Whenever there is trouble with mould on butter it is advisable to soak the wrappers in salt brine before using. When paraffine paper is first used and a parchment wrapper put over this, the latter need not be soaked in brine. Conditions at creameries under which wrappers are kept would infiuence the treatment necessary for them. If they are kept in a clean, dry place there is little danger of their becoming infected with mould gcrms to the extent that special treatment would be necessary. They should be kept in a clean, dry, well ventilated place.

149. Brand on wrapper. Unless a creamery is making enough butter to establish a trade or outlet of its own it is not advisable to carry one's own brand on the wrapper. In order to establish a recognized market for one creamery, it is necessary for that creamery to manufacture practically all butter of one grade. This is impossible under average creamery conditions. 'There are very few creameries so situated as to be able to sell even a small percentage of their butter under their own brand. Generally speaking it is not advisable to try to sell to commission houses under your own brand, but it is better to sell your butter to them under their own brand. Selling butter under the brand of some butter house is advisable because such firms usually have outlets for butter of various grades and sell practically all butter by grade. Since these firms receive butter from a large number of creameries, which do not manufacture butter of one grade, it is necessary for them to grade all butter. 
HANULFNG OF BC'I"IFIR IFTER CIIURNING. 111

\section{Treating Butter Tubs or Boxes for Mould.}

150. Frequently great losses to creameries have been incurred by the moulding of butter tubs and boxes shortly after the shipments of butter have reached the commission house. Instances are known where the mould grew on both the liner and the tub and penetrated into the outside parts of the butter. In order to avoid the loss and inconvenience oecasioned by the development of mould, paraffining as a remedy was suggested and tried with very good results. There are several other simple and inexpensive remedies which, when properly applied, give very good results. For instance the following:

1. Tighten all hoops, scrub the tubs with a stiff brush and hot water, turn over a steam jet and heat quite hot. Now fill the tubs with clean well water and soak until the tub and cover weigh eleven pounds. When ready to pack the butter, sprinkle salt with a sieve all over the inside of the tub. Have the liners soaked in brine, line the tubs and again sprinkle salt all over the liner and bottom circle. The tub is now ready for packing the butter.

2. Another method is that of soaking the tubs in a brine solution. Have a tank made of a size large enough to hold the number of tubs required for one day's make in the flush of the season and fill this tank with either a strong salt solution or a formaldehyde solution. Place the tubs in this tank and soak them until tub and cover together weigh eleven pounds. When tubs are treated in this way no salt need be sprinkled on either the tub or the linèr, but liners and circles should always be soaked 
in brine for twelve hours before using as mould spores may adhere to them and grow after the butter is packed.

3. Paraffine properly applied is one of the greatest safeguards agajnst mould and is very easily done with modern paraffining apparatus. Considering the benefits derived from its use as a means of preventing mould, the cost of it per package is a mere trifle. It $\mathrm{nxcludes}$ the air from the butter by sealing all creviecs and in this way increases the keeping quality of the butter. It is claimed that losses in moisture are Iress in paraffined than in unparaffined packages. If the soaking and handling of the packages were always performed in the best possible manner there would be less need of paraffining, but since this is not realized in the average creamery it is recommended that paraffining be generally employed as a safeguard against mould.

151. Methods of applying paraffine. The quickest as well as the most reliable and economical method of applying paraffine is with apparatus especially devised for this purpose. The cost of paraffining need not be more than one cent per 60 pound package of butter, whether it is a tub or a box. One ounce of paraffine will thinly coat one 60 pound tub and two ounces will give it a heavy coat. The cost would depend somewhat upon the smoothness of the package and the manner of applying the paraffinc. One of the main factors influencing the cost of paraffining is the temperature of the paraffine when applied. The hotter it is the less it will require. Sixty pound butter tubs which have a standard tare of 
eleven pounds each, including cover, should always be soaked until the tub and cover weigh eleven pounds and then paraffined as usual. In this way the creamery does not sustain any losses which are due to the difference between the tare (11 pounds) and the actual weight of the tub and cover.

152. Average shrinkage of butter. In addition to information gathered from thousands of creameries by personal visits, a large number of inquiries were made by letter in regard to the average shrinkage allowance or loss between churn weight and market return weight. It was found to be $1 \frac{1}{4}$ per cent of the total butter churned. This is the average loss, as the shrinkage given ranged from nothing to 4 per cent. Some claim that paraffining does not prevent this loss, as a certain shrinkage must be allowed in order that the dealer does not lose by shortage in weight.

For further information regarding how losses affect the overrun, see Book II., Dairy Arithmetic, p. 215. 


\section{CHAPTER IX.}

\section{CONTROLLING MOISTURE IN BUTTER.}

In the consistency of the butterfat lies the secret of controlling moisture in butter. 


\section{INDEX TO CHAPTER IX.}

l'ill. No.

I'agu.

153. Education necessury ................. 116

151. Progress evident ................... $116^{2}$

155. Fundamental principles must be studied....... 117

156. Moisture an be controlled...............117

Table $V$, Uniform moisture in finished butter.

157. Anilysis of results, Table $r \ldots \ldots \ldots \ldots \ldots \ldots 119$

158. Table VI, apparently same metluods as in Table V 129

159. Explanation of Table TI.............. 120

160. Not always the same results............. 121 Table VII, a study of six clumings.

161. Table VIII, shrinkage in moistnte.......... 12.

102. Explanation of Tables VII and VIrr........ 122

i63. How the churn moisture test was made....... 124

164. A churning showing certain methods and effect.. 12. With explanatory Table IX.

105. Description of methods employed........... 1..

166. Causes affecting moisture control........... 126

(a) How not to exceed the legal per ceut of moistule.

(b) Suggestions regarding expelling moisture.

167. Variations in moisture at different stages...... 127 Table X. Methods used.

168. Per cent of moisture and firmness of butter..... 128 Table XI. Results of ten churnings.

169. Per cent of moisture in different parts of churn. . 130 Table XII. Result of moisture tests.......... 130

170. How to take a composite sample of butter for moisture ........................... 131

171. Samples taken from tubs............... 131

172. An exceptional case ................. 132

173. Factors most necessary for controlling moisture.. 132 


\section{CHAPTER IX.}

\section{Controlling Moisture in Butter.}

153. The desired or required per cent of moisture in butter is very easily controlled when the fundamental principles involved in the retention, expulsion, and incorporation of moisture are understood by the creameryman.

Butter can be manufactured with fairly uniform moisture content, provided proper facilities for handling the various processes are available. The butter maker should so educate himself as to be able to meet unusual conditions as they arise. $\mathrm{He}$ should acquaint himself with all methods which affect the variations of the composition of butter, especially with regard to increasing, retaining and expelling moisture.

154. Some undesirable methods employed in the handling of cream and in the manufacture of butter have been, to a great extent, eliminated in the last few years by the enactment of suitable laws affecting these methods. A great advancement toward the employment of better and more uniform methods in the handling of eream and the manufacture of butter is already manifest.

The maximum per cent of moisture allowed in butter is 15.9 per cent, and this is fixed by federal law. This has created a tendency toward the manufacture of butter of a more uniform composition, which is very desirable, from an economic point of view. 
155. The great difference in the construction of machinery used in the handling of cream and in the manufacture of butter as well as the different methods employed in different creameries is bound to produce butter which varies greatly in the per cent of moisture it contains. The following facts are intended to assist the manufacturer of butter to a better understanding of the fundamental principles involved in the control of moisture.

In order to avoid trouble we ought to know what methods are likely to get us into trouble. Realizing 1he danger of the application of wrong methods as well as the danger of the wrong application of proper methods in the manufacture of butter it becomes necessary to discuss various methods bearing on the control of moisture in the manufacture of butter.

156. Moisture can be controlled. By a close application of the principles affecting the retention and expulsion of moisture it is possible to control moisture in butter uniformly and satisfactorily from day to day. This can be done without employing any of the so-called "abnormal methods" in the manufacture of butter.

\section{Uniform moisture in finished butter when cream varies in quantity and richness.}

The results in the following table indicate that the richness and quantity of cream used have apparently no effect on the moisture content of the finished butter. By studying carefully the methods used and applying the same at the proper time dur- 
ing the manufacture of butter, conditions affecting the moisture content can be controlled and the desired por eent of moisture "an be retained in the buttor. That the results in Table V., page 119, were so uniform is due to carefully watching details conneeted with the various operations during the whole process. For instance, compare churning No. 1 with churning No. 6. In No. 1 the quantity of cream is much less than in No. 6; the cream test is low in No. 1 and high in No. 6; the temperature of the wash water used is lower in No. 1 than in No. 6. The foregoing factors are in favor of higher moisture in No. 6. To offset this, No. 1 had a higher cream temperature and received twenty revolutions in washing against six revolutions in No, 6, which had a lower 'ream temperature. Since the temperature of the wash water was lower in No. 1 than in No. 6, No. 1 was churned more in a larger quantity of wash water than No. 6. By drawing off the water sooner in No. 6 , it did not have time to affect the temperature of the butter granules much even though the water was warmer. Churning No. 6 was drained quite dry while in No. 1 more water was left in the churn at the time the salt was added and the butter worked. By carefully studying these two churnings it will be noticed that where one factor favored high moisture another factor favored low moisture. In the uniform and relativinadjustment of those factors lies the seret of properly handling churning processes from day to day. Study whurning No. 3. Factors conducive to high moisture are: High cream test and fairly high 'hurning temperature. Factors con- 
ducive to low moisture content are: Washing butter in slow gear, fifteen revolutions (which has a tendency toward making the granules firm), draining butter quite dry, and using low temperature wash water.

Not only is such balancing of methods necessary in order to get uniform results, but one must also be able to judge by the condition of the butter fat during the various stages, how long or how short each period of handling must be. The operator must also study conditions as they arise in order to know the quantity and temperature of water to be used with such changed conditions.

\section{TABLF $\mathrm{r}$.}

Uniform Moisture in Finished Butter When Cream Varic's in Quantity and Richness.

\begin{tabular}{|c|c|c|c|c|c|c|}
\hline No. of Churnings & 1 & 2 & 3 & 4 & 5 & 6 \\
\hline Gream I'ounds $\ldots . . . . .$. | & 962 & 1351 & $1424 \mid$ & 1324 & 1409 & 1180 \\
\hline Cream Tests (averages)... & 23.4 & $30.15 \mid$ & 28.56 & 23.4 & 23.1 & $\overline{31.8}$ \\
\hline Cream 'Cemperatures ${ }^{\circ} \mathbf{F} . .1$ & 56 & 54 & 56 & 511 & 58 & $\overline{54}$ \\
\hline Buttermilk " " & 58 & $\overline{57} \mid$ & 57 & $5 \pi$ & 58 & 56 \\
\hline Wash Water “ & 51 & 55 & $54 \mid$ & $54 \mid$ & $54 \mid$ & 57 \\
\hline Slow Gear in Wash Water| & & $\ldots$ & $\ldots \ldots \cdot$ & $15 \mid$ & $\cdots$ & $\overline{\cdots \cdots}$ \\
\hline Rev. Churned in Wash & & & & & & \\
\hline Water ............. & 20 & 40 & $30 \mid$ & 151 & 30 & 6 \\
\hline Quantity of Butter to & & & & & & \\
\hline Water $\ldots \ldots \ldots \ldots \ldots \ldots$ & $1-\overline{11}$ & $1-3$ & $1-3$ & $1-4 \mid$ & $\ldots \ldots$ & $1-3$ \\
\hline Rev. Incorporating Salt...! & 13 & 13 & $13 \mid$ & $13 \mid$ & $13 \mid$ & 12 \\
\hline Temperature of Butter ${ }^{\circ} \mathrm{F} \mid$ & 56 & 56 & $56 \mid$ & $56 \mid$ & 57 & 56 \\
\hline Moisture Averages $\%$. & 15.-1 & 15.80 & 15.00 & 15.00 & 15.00 & 15.17 \\
\hline
\end{tabular}


158 Apparently applying the same methods as those used in table No. V.

TABLE VI.

Imparcully Applying the Same Methods as Those Uscd in Table No. V.

Temperatures all in Fahrenheit Degrees.

\begin{tabular}{|c|c|c|c|c|c|c|c|c|c|}
\hline No. of Churnings & 1 & 2 & 3 & 4 & 6 & 6 & 7 & 8 & $\theta$ \\
\hline Cream pounds --- & 460 & 1000 & 1296 & 1180 & 800 & 1344 & 1160 & 1000 & 1747 \\
\hline Cream tests \% fat & 27 & 36 & $291 / 2$ & 25 & 32 & 28.2 & 30 & 35 & 23 \\
\hline Cream temperature & $55^{\circ}$ & $52^{\circ}$ & $56^{\circ}$ & $53^{\circ}$ & $54^{\circ}$ & $55^{\circ}$ & $52^{\circ}$ & $46^{\circ}$ & $52^{\circ}$ \\
\hline $\begin{array}{l}\text { Buttermilk temper- } \\
\text { ture }\end{array}$ & $58^{\circ}$ & 54 & $58^{\circ}$ & $57^{\circ}$ & $55^{\circ}$ & $56^{\circ}$ & $54^{\circ}$ & $56^{\circ}$ & $55^{\circ}$ \\
\hline $\begin{array}{l}\text { Wash water teri- } \\
\text { perature }\end{array}$ & $5 i$ & $566^{\prime}$ & $56^{\circ}$ & $52^{\circ}$ & $56^{\mathrm{c}}$ & $53^{\circ}$ & $52^{\circ}$ & 53 & $55^{\circ}$ \\
\hline $\begin{array}{l}\text { Quantity of butter } \\
\text { to water }\end{array}$ & $1-3$ & $1-3$ & $1-3$ & $1-3$ & $1-2$ & $1-2$ & $\ldots$ & $1-2$ & $1-2$ \\
\hline $\begin{array}{l}\text { Riv. churned in } \\
\text { water }\end{array}$ & 30 & 60 & 24 & 30 & 6 & 15 & 20 & 30 & 10 \\
\hline $\begin{array}{l}\text { Rov. horked in } \\
\text { water }\end{array}$ & $\ldots$ & 10 & 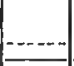 & ด & 10 & 12 & 6 & 10. & $\ldots$ \\
\hline $\begin{array}{l}\text { Temperature of } \\
\text { finfshed butter. }\end{array}$ & $58^{\circ}$ & $56^{\circ}$ & $59^{\circ}$ & $56^{\circ}$ & $56^{\circ}$ & $64^{\circ}$ & $52^{\circ}$ & $54^{\circ}$ & $56^{\circ}$ \\
\hline $\begin{array}{l}\text { Average percent of } \\
\text { molsture }\end{array}$ & 18.33 & 18.10 & 18,75 & 17.60 & 17.1 & 17.12 & 17. & 16.53 & 17.25 \\
\hline $\begin{array}{l}\text { Condition of but- } \\
\text { ter }\end{array}$ & $\begin{array}{l}\text { Dull } \\
\text { and } \\
\text { weak } \\
\text { body }\end{array}$ & $\begin{array}{l}\text { Dull } \\
\text { and } \\
\text { weak } \\
\text { body }\end{array}$ & $\left|\begin{array}{l}\text { Soft } \\
\text { in } \\
\text { body }\end{array}\right|$ & $\begin{array}{l}\text { Very } \\
\text { dry } \\
\text { body }\end{array}$ & $\begin{array}{l}\text { Fair } \\
\text { body }\end{array}$ & $\begin{array}{l}\text { Fair } \\
\text { body }\end{array}$ & $\begin{array}{l}\text { Very } \\
\text { dry } \\
\text { body }\end{array}$ & & \\
\hline $\begin{array}{l}\text { 8-Simplex. } \mathbf{\nabla}- \\
\text { VIctor }\end{array}$ & s. & 8. & v. & v. & V. & S. & $\mathbf{8 .}$ & V. & V. \\
\hline
\end{tabular}

159. The per cent of moisture in the finished buttr. $r$ is very much greater as shown in the above table than given in table No. V. The methods in table No. VI. do not vary murh from those used in table No. V. The difference in results indicated in table 
VI. is wholly due to the proper (table No. V.), or improper (table No. VI.) application of methods used. The body of butter is usually weak whenever the moisture exceeds $161 / 2$ or 17 per cent and is decidedly soft when it exceeds 19 per cent.

No rule which is applicable to all conditions alike, can be formulated because conditions under which butter is made, vary very much. Not only are the results obtained affected by a variation of conditions under which butter is made, but different butter makers judge conditions differently. Due to this, no rule can be formulated which could be used under all conditions. However, by having a perfect system of cream standardization, by knowing the exact quantity of cream used at each churning and by a careful adjustment of temperatures, very good results can be obtained by following a definitely outlined method.

160. Not always the same results. In order to determine how much the per cent of moisture would vary by employing the same methods, six churnings were made from the same lot of cream. These churnings were all made in the same churn and within ten hours time. In the table bclow will be found the result of these churnings :

Six churnings made from the same lot of eream.

After the butter had stood for four days in a freezer, it was retested for moisture and the samples were taken with an ordinary butter trier. The results obtained are given below. 
'I'ABILE VII.

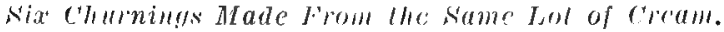

\begin{tabular}{|c|c|c|c|c|c|c|}
\hline 870 & 1 & 2 & 3 & 4 & 5 & 6 \\
\hline ream Pounds & 301 & 3011 & $: 3(1)$ & 300 & $300 \mid$ & \\
\hline er Cent Butter Fat & 24. & $2: 3.81$ & 24.1 & 24.31 & $24 . \mid$ & 24. \\
\hline \multicolumn{7}{|l|}{ lime Churned (in min- | } \\
\hline utes ) $\ldots \ldots \ldots \ldots \ldots \ldots$ & 31 & $2 ! !$ & $30 \mid$ & $2 \pi$ & $27 \mid$ & \\
\hline \multicolumn{7}{|l|}{ Temperature of Butter- } \\
\hline milk $\ldots \ldots \ldots \ldots \ldots \ldots$ & $57^{\circ}$ & $\overline{5 i 01}$ & $57^{\circ}$ & $57^{\circ}$ & $57^{\circ}$ & 57 \\
\hline \multicolumn{7}{|l|}{ Femperature of Wash } \\
\hline$\ldots \ldots \ldots \ldots \ldots$ & $52^{\circ}$ & $52^{\circ}{ }^{\circ}$ & $5: 3^{\circ}$ & $53^{\circ}$ & $53^{\circ}$ & 53 \\
\hline ev. Churned in water... & $15 \mid$ & 15 & 1.5 & $15 !$ & $1 \overline{5}$ & 1 \\
\hline Rev. Worked in Water... & 10 & 10 & 10 & 10) & 10 & 1 \\
\hline Temperature of Butter...। & $56^{\circ}$ & $55^{\circ} 1$ & $\sin ^{\circ}$ & $513^{\circ}$ & $56^{\circ}$ & $56^{\circ}$ \\
\hline hurn Moisture Test \%.. & & & & & & \\
\hline
\end{tabular}

161. Shrinkage in moisture.

'TABLE VIII.

shrinkage in Moisture.

\begin{tabular}{|c|c|c|c|c|c|c|}
\hline No. of Churnings & 1 & 2 & 3 & 4 & 5 & 6 \\
\hline $\begin{array}{l}\text { After Four Days. } \\
\text { 'Tessted from Tub. Mois- } \\
\text { ture } \ldots \ldots \ldots \ldots \ldots \ldots .\end{array}$ & 12.70 & 12.78 & 12.72 & 19.211 & 18.7 .5 & 12.50 \\
\hline Slurinkage ... . & $S(1)$ & .72 & .18 & $\mid \begin{array}{r}\text { Gainu } \\
.10\end{array}$ & .50 & .50 \\
\hline
\end{tabular}

162. The average shrinkage in five out of six tubs is 54 por.cont wer 1ul). The gratest variation in moisture in this lot is 1.35 por ant. The quantity 
of wash water used in each churning was one-half the volume of the cream churned. The butter was first rinsed with watcr of the same temperature as the water used for washing. In order to ascertain what effect these quantities of wash water at the temperatures mentioned had on the moisture content and on the quality of the butter, the butter was worked ten revolutions in the water, in slow gear. It can readily be seen that under such conditions and temperatures the moisture content was not high. As far as could be detected these churnings had the same firmness of body and handled about the same during the manufacturing process. The foregoing trial would indicate that the moisture in butter will vary somewhat, even though the butter is made under the same conditions.

During a period of four days, between the churu test and the tub test, the average moisture shrinkage was .54 per cent. For some reason one tub did not show any shrinkage, one showed .18 per cent and four showed above .50 per cent shrinkage. The cause of the high shrinkage on this butter may be due in part to loss of moisture during the packing of the butter and to sampling it from the tub with a trier when quite cold, thus losing a little water by drawing the plug. It is claimed by some creamerymen that the churn moisture test can be 17 per cent and the butter will not contain more than 16 per cent of moisture when it reaches the market. I wish to caution butter makers against putting faith in such cleaims because well made butter does not always lose one per cent of moisture from the time it 
is churned, packed and held at the ereamery until it reaches the market.

163. How the churn moisture test was made. After the working of the butter was finished, a threepound compact chunk was taken from the churn. The sides were cut off until one pound was left, and from this piece a cube weighing about ten or fifteen grams was cut and placed in a Patrick aluminum beaker or in a Wisconsin high pressure oven pan, and hcated until all moisture was expelled. By using this method the duplicate samples compared well. and seemed to prove the method an accurate one and one which can well be used in creamery practice for approximate results. A Disbrow churn was used for these churnings. The sampling and retesting of the tub butter was done in the same manner, "xiept that a tric' was used, and several plugs 1aken from each tub. From each plug a few grams were tak'n ('nough to make 10 or 15 grams), placed in the pan or eup, and heated until all the moisture was expelled. Both these methods compared well with standard methods.

The character of butter has much influence on the results obtained and must always be taken into consideration when comparing the results obtained and (hecking up work done. A common cause of poor and variable results in testing butter for moisture is the us' of improper methods, wither in taking samples from the "hurn or from the tul), and in not weighing the sample corronly before and after testing. In order to get a representative sample from the churn, larger guantities of butter than one or 
two ounces must be taken, from which to make the moisture determination. Let me warn butter makers against taking a little bit of butter from one place in the churn, with a jackknife, ladle or the fingers, for testing for moisture. Such a small piece of butter taken at random does not, as a rule, represent the average moisture in a churning.

164. Eight churnings showing certain methods and their effect on moisture.

TABLE IX.

\begin{tabular}{|c|c|c|c|c|c|c|c|c|}
\hline No. of Churnings & $\overline{1}$ & 2 & 3 & 4 & 5 & 6 & 7 & 8 \\
\hline Cream pounds & 1500 & 1343 & 1747 & 1150 & 1887 & 1280 & 1445 & 1150 \\
\hline Cream tests \% & 32. & 36.5 & 23. & 30. & 25.6 & 30.6 & 27. & 30 . \\
\hline Oream temperature ${ }^{\circ} \mathbf{F}$ & $54^{\circ}$ & $54^{\circ}$ & $52^{\circ}$ & $52^{\circ}$ & $54^{\circ}$ & $55^{\circ}$ & $55^{\circ}$ & $52^{\circ}$ \\
\hline Buttermilk temperature ${ }^{\circ} \mathrm{F}$ & $55^{\circ}$ & $56^{\circ}$ & $55^{\circ}$ & $54^{\circ}$ & $56^{\circ}$ & $57^{\circ}$ & $56^{\circ}$ & $55^{\circ}$ \\
\hline Wash water temperature ${ }^{\circ} \mathbf{F}$ & $56^{\circ}$ & $52^{\circ}$ & $55^{\circ}$ & $52^{\circ}$ & $52^{\circ}$ & $57^{\circ}$ & $52^{\circ}$ & $53^{\circ}$ \\
\hline Rev. churned in wash water.- & 6 & 10 & 10 & 20 & 25 & 56 & 25 & 30 \\
\hline Rev. worked in water. & 10 & 7 & 8 & 6 & 3 & 30 & 5 & $-\infty$ \\
\hline Rev. worked incorporating sa & 12 & 12 & 12 & 13 & 14 & 14 & 12 & 13 \\
\hline Temperature of butter " $\mathrm{F}$ & $56^{\circ}$ & $52^{\circ}$ & $56^{\circ}$ & $52^{\circ}$ & $54^{\circ}$ & $53^{\circ}$ & $53^{\circ}$ & $54^{\circ}$ \\
\hline Per cent moisture (averages) & 16.6 & 17.65 & 17.25 & 17. & 15.93 & 16.45 & 17. & 17. \\
\hline No. of moisture determinations.. & 13 & 3 & 2 & 2 & 4 & ह & 4 & \\
\hline
\end{tabular}

tVictor churn was used.

165. Whether such methods as are given in the above table can or cannot be employed to advantage in creamery butter making is a question that can be decided only by the butter maker himself. Results obtained would depend absolutely upon his ability to handle properly all processes involved in churning the cream and working the butter. In order to understand any one method that may be employed 
in rrantry butter making, all sides must be well studird and we must sor into and understand what conditions affect an increase or a decrease of moisture in butter.

In crery ons of the rhurnings in table $1 X$, cxeept No, 8 , the buttre was worked in water after being washed. The quantity of water used in the first five: rhurnings was twion the amount of the buttor churned. In numbers $1 ;, 7$ and 8 , the quantity of water used was thres tinu's the amount of the butter "hurned. Working the huttre in water has a tendency to inerease the moisture unless the butter is quite firm. The rate at which moisture in butter is increased by working the buttor in water depends more upon the condition of the butter fat than upon the number of revolutions given in water. The solidity of the buttar fat dotermines the rate of increase or drerrase of moisture in butter during the washing and working processes. Under proper conditions butter may be worked a little in water without necessarily spoiling thoss qualities which 'nter' into the makeup of perfect buttar.

166. Retaining and increasing moisture in butter. Moisture may be increascol and retained in the following ways:

I. By churning cream at a high temprrature.

II. By overehurning.

III. By rhurning very rich "r'ram.

IV. By washing with warm water and churning the butter into lumps in the wash water. 
V. By working butter in water and leaving water in the churn while incorporating salt.

VI. By overworking butter in water.

VII. By churning cream very soon or at once after cooling.

\section{Expelling Moisture.}

A. How not to exceed the legal moisture limit. Churn cream at low temperatures. Churn butter to fine granules. W'ash butter with cold water. IIold butter in cold water for some time in order that butter granul's may become firm. Drain butter dry before adding salt and working butter. Wash butter at intervals, giving a few workings at a time. Maintain firm butter fat during the whole process of butter manufacture, and low moisture is the result.

B. A few suggestions regarding expelling moisture. This can be accomplished by letting the butter stand in the churn until it has set, then start the churn, set the workers in motion, and work as usual until the moisture is sufficiently reduced. If the churning room is so warm that the butter cannot harden or become firm in the churn, put the butter into soaked, unlined tubs and place in cooler until set. Then work as stated above. Hardening butter fat is the only means of expelling moisture and is also the most effective way of preventing too high moisture content.

167. Variations in moisture at different stages during the churning and working processes.

It is interesting to note how the moisture content changes during different stages of the manufactur- 
ing process. In the experiments noted in the foregoing table, the wash water was tempered to $54^{\circ}$ and $55^{\circ} \mathrm{F}$, and the temperature of the cream was about $52^{\circ} \mathrm{F}$. when put into the churn. This table seems to indicate that cold water has a tendency to

TABLE $\mathrm{X}$.

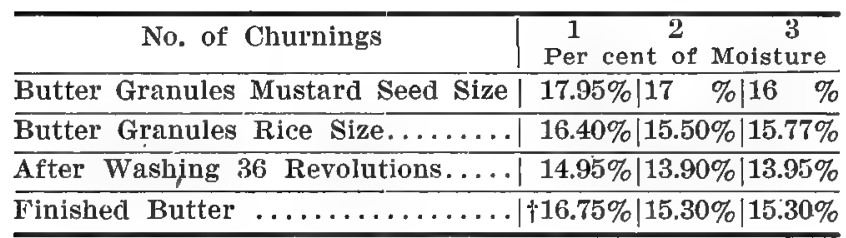

† All average of six determinationf.

\begin{tabular}{|c|c|}
\hline & Per cent of \\
\hline atter Granules IRice Size. & $14.20 \% \mid \ldots$ \\
\hline ter Washing 10 Revolutions. & $14.65 \%$. \\
\hline ffter Washing 20 Revolutions..... & $13.40 \%$ \\
\hline ter Washing 30 Revoluti & $13.50 \%$ \\
\hline orking 6 IRevolutions in & $\mathbf{1 4 . 5 0 \% | .}$ \\
\hline rking 6 liev. & 157 \\
\hline
\end{tabular}

lower the moisture content of butter during washing under certain conditions, but the moisture can be increased by allowing a little water to remain in the churn during the incorporation of the salt.

168. Per cent of moisture and the firmness of butter.

The cream used in the above churnings was of such a temperature as to insure exhaustive churn- 
ing. The wash water used ranged from $51^{\circ}$ to $54^{\circ}$ F. After the butter had been washed it was salted, and the working finished immediately without any stop except about five minutes which was necessary

TABLE XI.

\begin{tabular}{|c|c|c|c|c|c|c|c|c|c|c|}
\hline No. of Churnings & 1 & 2 & 3 & 4 & 6 & 6 & 7 & 8 & 9 & 10 \\
\hline $\begin{array}{l}\text { Consistency of but- } \\
\text { ter }\end{array}$ & & & Soft & Hard & $\begin{array}{l}\text { Very } \\
\text { hara }\end{array}$ & $\begin{array}{l}\text { Not } \\
\text { very } \\
\text { soft }\end{array}$ & Soft & Soft & $\begin{array}{l}\text { Me- } \\
\text { dium }\end{array}$ & Soft \\
\hline $\begin{array}{l}\text { Per cent of moisture } \\
\text { after washing }\end{array}$ & 14.75 & 13.90 & 14.60 & 15.15 & 16. & 14.75 & 13.75 & 14.66 & 14.50 & 14.95 \\
\hline $\begin{array}{l}\text { Change in moisture } \\
\text { during the incor- } \\
\text { poration of the } \\
\text { salt }\end{array}$ & $16 .-$ & 15.30 & 16.60 & 14.45 & 13.50 & 14.36 & 16.25 & 15.10 & 15.30 & 16.75 \\
\hline $\begin{array}{r}\text { Increase }+ \text { De- } \\
\text { crease }-\end{array}$ & + & $\stackrel{+}{1.40}$ & $\stackrel{+}{1.90}$ & -.70 & $\overline{2.50}$ & - & $\stackrel{+}{+} .50$ & $\stackrel{+}{.44}$ & +.80 & ++ \\
\hline
\end{tabular}

in order to obtain a fair sample of butter to be used for moisture determinations. About ten or fifteen pounds of water was left in the churn in all of the above churnings to facilitate the dissolving of the salt and to increase the moisture content of the butter. The finished butter was all in a fine, waxy condition, not slushy, salvy nor gritty. By carefully watching conditions, the moisture in butter can be increased as much as 2.35 per cent during the incorporation of the salt. In all of the above churnings, the butter was worked only enough to properly incorporate the salt and avoid mottles. The results shown in table XI. seem to indicate that the moisture in butter is retained, increased or expelled according to the firmness of the butter fat. This is noticeable in churnings 4,5 , and 9 . 
169. Per cent of moisture in different parts of churn. Result of moisture tests.

TABLE XII.

Result of Moisture Tests.

\begin{tabular}{|c|c|c|c|c|c|c|c|c|c|}
\hline No. of Ohurnlngs & 1 & 2 & 3 & 4 & 5 & 6 & 7 & 8 & Average \\
\hline Molsture \% gear end. & 15.30 & 15.2 & 16.25 & 14.14 & 14.90 & 16.90 & 15.75 & 15.45 & 15.47 \\
\hline Molsture $\%$ middle & $\overline{15.60}$ & $\overline{16.1}$ & 15. & $\overline{16.35}$ & $\overline{14.88}$ & 16.40 & 16.35 & $\overline{15.06}$ & 15.38 \\
\hline Molsture \% drain end. & $\overrightarrow{17.00}$ & 16.00 & 14.6 & 16.76 & 17.00 & 15.50 & 16.75 & 15.60 & 16.19 \\
\hline
\end{tabular}

Since the churns in most creameries are set inclined toward the drain end, the water collects at that end of the churn during working of the butter, therefore a great difference in the per cent of moistture in the different parts of the churn is noticeable. In fact, there is so much differen'r that, in order to obtain an average moisture determination, a composite sample composed of samples taken from different parts of the butter in the churn is necessary, and from this sample the moisture determination must be made. This difference in moisture in different parts of the churn is found to bre greater in churns in which the butter is wriscel into one long column. The middle part of the rolumn has the least moisture, the butter at the garre sut has slightly more, aud that at the Jrain ond, the highest moistture. The greater the julline of the churn, the greater the moisture at the lower end. This variation in the per 'ant of moisture, is partly, if not wholly, due to the division of water in the churn during the time that the butter is worked. Through the spreading of the workers while working, the butter passes more quickly through the middle of 
the rollers and strikes the sides of the churn before the ends of the column strike it. This divides the water in the churn and forces it to the ends, which causes the butter to be drier in the middle of the churn than at either end. This can be overcome, to some extent, by setting the churn level and handling the churning in such a way as to produce butter of a rather soft consistency.

170. How to take a composite sample of butter for moisture determination. Take a spatula, a common broad knife, or a cheese or butter trier, and a common cup or beaker, and take about one-fourth of an ounce of butter from different parts of the churn, until two or three ounces have been obtained. Place the samples in the cup or beaker and set the latter into a water bath having a temperature of about $98^{\circ} \mathrm{F}$. Stir constantly until you have a smooth, soft pastc. 'This now constitutes your composite sample and is to be used for moisture determination. From it take 10, 15 or 25 grams, or any desired quantity. Weigh it accurately and place in a cup or drying pan and follow the directions on whatever moisture testing apparatus is used.

171. Samples taken from tubs. It is well to take a very small quantity of butter from each tub while it is still soft and fresh from the ehurn, to form the composite sample to be used for testing the moisture content. Prepare this sample as previously stated and test as usual. The test made from the composite tub sample will, as a rule, show a truer average, and when this is compared with the test made from the churn composite sample and does not check up quite 
closely, another test ean at once be made and the error located.

172. An exceptional case. A special churning was made to determine what the results would be when special precautions were taken in ripening the cream, in churning, and in washing and working the butter. To the surprise of those who examined the butter when a week old, it was found that it contained 18 per cent of moisture and scored $96 \frac{1}{2}$ points. This score was the average of the scores of three judges. Upon critical examination it was found that the body of the butter gave way more easily under the trier, than butter having a lower moisture content. It must be remembered that this was as exceptional case, and that butter with 18 per cent of moisture, as ordinarily made, would be quite different. If. I. Puxley, in Modern Dairy Farming, Chapter XI., p. 107, 1906, says: "Even good butter contains a large percentage of water, but this should never be more than 15 per cent."

I wish to emphasize the fact that it is not so much in the increase of one or two per cent of moisture, that the main danger of producing poor butter lies. It is the quality of the raw material which is usually at the bottom of most of our trouble with butter faults.

\section{Factors most necessary for controlling moist-} ure. Even though there are a great many conditions which affect the per cent of moisture in butter, there is no one factor which affects the moisture to a greater extent than a properly educated man at the churn. Next in importance, are the temper- 
atures applied and the methods used. The kind of machinery used also plays an important part in affecting the methods used in regulating the moisture content of butter. Such conditions as the season of the year, the sort of feed the cows are fed, and the richness, age, and acidity of the cream, are of minor importance and the effect of these conditions on the moisture content of butter can very (asily be overeome by the operator with good judgment. 


\section{CHAPTER X.}

\section{BUTTER FAULTS.}

Cream lacten with miscellaneous germs has bad keeping qualities, and often a faulty taste or odor. Most of the so-called faults of butter aris', not from improper feeding of cows or from improper milking or handling of butter, but from undesirable germs which infest it.

KENEIM WINSTOW. 


\section{INDEX TO CHAPTER X.}

I'ar. No.

Page.

Part r. Butter Frults as Affected by Conditions on Dairy Farms.

174. Classigication of butter faults............ 136

175. Quality of butter affected by farm conditions.... 136

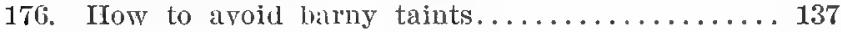

177. Care of tainted creau at reamery.......... 137

178. Source of cowy odor................. 138

179. Cause of musty flavol in milk or cream....... 138

180. ('iuse of sweetish fluror in wilk or cream...... 139

18.1. What may be dome to improve cream having a sweetish flavor ................... 140

182. Some caluses of burnt thavors............. 140

183. Sources of high acid in cream............ 141

184. Bitter flavors ..................... 142

185. Care of milk and cleam to avoid salvy butter.... 142

Part II. Butter Faults Due to Improper Iandling of

Cream at the Creamery............... 143

186. Regarding burut flavors in buttex........... 14.3

187. Burnt flavor due to struter, how prevented...... 144

188. Cause and prevention of acid favors.......... 145

189. Cause and prevention of coarse flarors........ 146

190. ('ause and prevention of unclean flavors....... 147

191. Cause and prevention of culdy flavors........ 147

192. Cause and prevention of specks in butter....... 148

I'art III. Fiutter Faults due to Fiulty Workmanship.. 149

19:3. Cause and proveution of leaky and slushy butter. 14!)

194. ('iluse and prevention of gritty buttel......... 151

195. Canke and prevention of mottled butter....... 151

19\%. Canse and prevention of salyy and greasy butter. 152

(a) I'asteurization of reall ........... 15?

(b) Churning of crean $\ldots \ldots \ldots \ldots \ldots \ldots \ldots \ldots \ldots 153$

(c) Washing of butter ...................

(d) Working of buttel ............... 155

197. Cause and prevention of oily butter.......... 155

198. Cause and prevention of woody flavor in butter.. 157

199. Cause and prevention of lardy or tallowy butter. 157

200. Cuuse and prevention of fislyy flavor in buttel... 157

201. Cause and prevention of brittle butter......... 158

20.2. Cause and prevention of unclenn faror in butter. 159

2(1);. Cause :uld prevention of conse flavor in butter.. 159 


\section{CHAPTER X.}

\section{Butter Faults.}

174. Butter faults may be divided into three maiu classes or divisions: I. Faults due to improper handling of milk or cream before it is delivered at the factory. II. Faults due to improper handling of the cream at the factory before churning. III. Faults arising from improper butter manufacturing processes.

\section{PART I.}

175. Butter faults as affected by conditions on dairy farms. The dairyman plays an important part in the success or failure of the local creamery. It is in a great measure in his power to make the production of fine butter possible. By neglecting to perform, in a proper manner, the detail part of the work (Hunziker*) pertaining to the production of clean milk (Winslow**) he throws a heavy burden of responsibility upon the shoulders of the creamery operator.

The insanitary conditions which still exist on some dairy farms are inexcusable and would not exist if the dairyman would only do as well as he knows how. Some of the methods used are out of harmony with modern knowledge and modern methods of dairying. Since the dairyman reads dairy literature, the use of even a small percentage of the

* Hunziker, Otto F., Cornell Agr. Expt., Sta. Bul. No. 197, Dec. 1901.

- "Winslow, Kenelm, Clean Milk, 1907. 
knowledge thus gained would do away with slack and old-time methods.

\section{A few suggestions regarding the care and handling of milk and cream on the farm.}

176. Barny taints. This peculiar taint (Rogers*) so widely known and occurring so frequently during the winter months, has its origin mainly in impurities arising from manure and dusty feed. It may, and often does, come from impure stable air; from dirty cows or dirty udders during milking; from separating the milk in the stable and keeping it there over night, and from filthy and insanitary stables and barnyards.

These taints may be prevented by installing a perfect system of ventilation (King*); by keeping the cows, the stable and the barnyard clean; by keeping the separator clean (washing it after every time it is used); by separating the milk in a clean room separate from the barn and having the milk room far enough away from all stable and barnyard odors.

177. In case the milk has acquired such taints, the creameryman must find a partial remedy for it. This taint can, in a measure, be overeome by skimming a heavy cream and diluting it with about ten per cent of clean, sweet morning milk. In addition to this, add from twenty to thirty per cent of a first class starter. Now ripen the eream to about .50 per cent acidity and cool at once to $48^{\circ} \mathrm{F}$., and hold at this temperature for about three hours before

- Rogers. L. A., W. S., Farmers, Bul. 348, 1909. 1890.

** King, F. H., The King System of Ventilation, Seventh Ann'l, Rept., 
churning. If the contaminated cream is hand-separator cream, pasteurize it if possible, then ripen and cool the same as mentioned above. Pasteurization always improves such eream and should always be used if possible. Add to this cream as heavy a starter as is possible without reducing the fat test below 23 per cent. Cool below churning temperature and hold at this temperature until ready to churn, which will be any time after the lapse of about two hours after cooling.

178. Cowy flavors. The cause of cowy flavors in butter is not well unclerstood. This peculiar taint may be the combined result of several minor causes. The general impression is that it is due to insufficient cooling and aerating of the milk before the cover is put on the 'an. Milk should not be aerated in impure air and should be cooled during the process of aeration. When milk is put warm into cans, the "over put on and the milk allowed to cool slowly, the fine Havor of the milk is spoiled. This will affect the flavor of butter, and for this reason the creamery operator should insist upon his patrons taking proper cares of the milk. (are and cleanliness, and having a grool system of cooling and aerating the milk at the farm, may do away with this odor in the milk.

179. Musty flavor in milk and cream. This flavor is due to the placing of milk in cans immediately after milking ('sprejally when the stable air is impure), closing the (ans and allowing the milk to cool slowly without stirring or alumijng. When milk has recoivel this tmatment and the wather is warm 
when it is sent to the factory, the heat from the outside causes the development of a peculiar musty flavor. The more slowly the milk cools, after having been placed warm in the cans, the more pronounced will be the musty flavor. This is especially noticeable when milk is carried for some distance in an open wagon.

The dairyman should cool the milk or cream well, stirring and aerating it at the same time before placing the cover on the can. If the air is exceptionally cool and pure, leave the cover off, placing only a fine-meshed screen over the can during the time the milk is held at the farm.

The creamery operator should use the same method in separating the milk and handling the cream as is indicated in the treatment of milk and cream for barny flavors. Pasteurization of the cream at the creamery is recommended, as this flavor will pass off to a great extent during heating and cooling.

180 Sweetish flavor. This flavor is very frequently found in milk or eream where various kinds of silage are fed. The sweetish flavor is perhaps not directly due to the feeling of such feeds but to the contamination of the milk or eream by the oulors given off from the feed. Milk or cream kept in the presence of odors from silage, especially soy bean silage, will very soon become contaminated by those odors. This sweetish flavor in milk or eream is very hard to deal with. The odors seem to penetrate into the butter fat itself and no amount of cooling, aerating, re-separating and diluting with sweet milk 
or fine starter will entirely rid the cream of this flavor.

When silage is fed on dairy farms, the King system of ventilation is indispensable and scrupulous cleanliness in all things pertaining to the handling and feeding of silage is absolutely necessary in order to avoid contamination of the milk or cream from the odors coming from the feed. Under no cireumstances should the milk be separated in the stable, nor should it be held in an atmosphere tainted by silage odor for any length of time.

181. There is really no remedy for this flavor, but the best thing for the creameryman to do is to separate a heary cream, pasteurize it, and then treat it according to directions for handling barny taints (176) in milk. If this taint is found in hand separator cream, dilute it with water and re-separate it if possible. If it cannot be re-separated, pasteurize it at a temperature not lower than $195^{\circ} \mathrm{F}$., and aerate it well while cooling. Add a heavy starter and stir frequently during the ripening process. Cool, hold for two or three hours, and then churn at as low a temperature as possible. Churn to very fine granules, wash twice with a liberal quantity of cold water, to which has been added one per cent of salt. Then salt quite heavily, work and dispose of the butter as soon as possible.

182. Burnt flavors. During the corn-cutting season, a peculiar, sweetish, scorched or burnt flavor is often noticeable in milk and cream. This seems to be due to the ov'lfeceding of rornstalks, all kinds 
of corn refuse, frozen grasses, pumplking vines and corn smut.

The ereamery man may find it to his interest to suggest 10 the dairyman that he be careful not to allow his cows to gorge themselves with all kinds of frozen herbage and refuse from the corn fields, but rather allow the cows only a limited amount of this feed each day.

These flavors cannot be altogether eliminated, but can be modified and lessened in volume by (in the case of milk) skimming a heavy cream, diluting it with good, sweet milk and adding a heavy starter. Both the milk and the starter added to this cream should be without this burnt flavor. Pasteurization of cream which has this flavor does not materially lessen it.

183. High acid, sour or vinegar flavors. These flavors have a common cause and are usually the result of allowing milk or eream to become too old before delivering it at the factory. These flavors are especially pronouneed when milk or eream is kept at too high a temperature at the farm or during transportation. The patrou should cool the milk or eream immediately when fresh, to a reasonably low temperature and hold it at this temperature until delivered. Ile should deliver both milk and cream frequently and avoid overheating during transportation. Milk and cream should always be kept in carefully cleaned utensils, in pure air and at a low temperature. Pasteurization of such cream will greatly improve the keeping quality of the butter and lessen, to some extent, the high acid flavors. 
Whin thr stantor is added, cool and stir thr cream frerpuntly until ready to churn. Churn at the lowest possible temperature, wash with cold water to which 2 per ernt of salt has been added, salt a trifle heavily and market quickly.

184. Bitter flavors. These flavors may have their origin in old, over-ripe rream and especially in cream produced under very insanitary ronditions. It may also be caused by a germ producing bitter fermentation. (Russell*.)

('lralliness in handling milk and cream on the farm is the way to prevent this flavor, but when it is found in milk or aream, the creamery operator will find the treatment previously outlined for vin('gar (183) Havors, of value.

185. Salvy, cily and greasy butter. The following are some conditions in hand separator eream previous to its delivery at the factory whirh may rause salvy or grosisy butter. Very rich croam which has bors overheated during transportation, partly "hurued cream and old aream, all produer this rondition in butter. P'artly "linrurel "ream has usually brem subjectod to violent agitation during transportation and this rondition invariably produces salvy or greasy butlor. Old croum as a rule has more? arid ancl is Jess viscous than fresh croam. It is more rasily churner during transportation. The longer the erant is in transit the worse is its condition upon arrival at the factory, especially if it is not well protected against the heat of the sun.

* Russell, L. H., Outlines of Dairy Bacteriology, page 151, 1894. 
Warm or newly separated cream should not be added to cold cream, but should be cooled to about the same temperature before mixing the two. When warm eream is added to cold, its warmth is likely to arouse the activity of spores which will cause abnormal fermentations in the cream. Mixing warm and cold cream in hauling cans, when ice is put into the cans, is the source of weak bodied, soft and greasy butter.

Cream haulers should have the cream cans well protected from the heat and should have a floating cream cover in every can. When the ordinary shipping cans are used, they should be full, or nearly so, in order to prevent unuccessary agitation of the cream. This agitation is likely to partly churn the cream and may cause losses in manufacturing the cream into butter.

\section{PART II.}

Butter faults due to improper handling of cream at the creamery.

186. Avoidable burnt flavor in butter. A number of different idcas hav been expressed as to the cause of burnt flavor in butter. Some have attributed this flavor to uncleauliness in the creamery, others to overheating of the cream during pasteurization, and still others hare thought that it might be caused by dirty iron pipes or rusty vats. It has been noticed that in some instances the burnt flavor was directly traceable to the starter and in other cases to water which had collected in iron pipes and which was not drained off after the work had been 
clone in the creamery. The water rusted in the pipes and when the milk was received and run through these pipes the rusty water mixed with the milk and produced a rusty iron flavor in the butter. Again this flavor has been traced to the starter; the milk for the starter having been overheated and the milk sugar scorched or caramelized. Milk under such conditions changes in color to a brownish shade. This peculiar scorched flavor in the milk produces a burnt flavor in the butter. A number of instances have rome under my observation, where butter makers have heated the starter milk twice or three times to boiling temperatures, caramelizing the milk sugar and leaving a decided burnt flavor on the milk. This burnt flavor did not leave the starter during ripening and when added to the cream imparted a burnt flavor to the butter. I believe that there are various ways in which a burnt flavor may be produced in butter, but if the previously mentioned causes are taken into consideration in ereamery manag(ment, burnt flavors need not appear in butter. When eream is well carod for, the creamery in a good sanitary condition, the pipes through which the milk and cream flow well cleanerl, and the "ream and starter milk not over heated at any stage, there will be little trouble with burnt flavor, unless it comes from some outside sourer.

187. Burnt flavor due to starter. When milk is heated to a temperature of $212^{\circ} \mathrm{F}$. for one or two hours and re-heated to boiling temperature, a change in the rolor of the milk is noticeable. It not 
only undergoes a marked change in color, but usually a decided burnt flavor is produced when milk is so treated. The milk sugar undergoes a change and whenever the quality of the milk sugar is affected, the quality of the lactic acid produced is likewise affected.

This defect can be prevented by not heating the starter milk to such high temperature as to affect the character of the milk sugar. Heat the milk to be used for a starter, once to a temperature of $180^{\circ}$ F. to $190^{\circ} \mathrm{F}$. and hold at this temperature for forty minutes. The finer qualities of milk for the production of a fine, clean, acid starter are partially if not wholly destroyed by overheating.

188. Acid flavor. This flavor is due to too high ripening of the cream, and to holding the ripened cream at too high a temperature before churning. It is also produced by holding ripened eream too long before churning. When cream is held over from one day to another there is danger of its developing a sour, acid flavor even though the acidity in the cream is low. Using an over-ripe starter may have the same effect on the cream as over-ripening it. Such acid flavors may be prevented by handling the cream in such a way as to prevent the development of lactic acid above .65 per cent. When cream has developed the desired degree of acidity it should not be held at ripening temperature because such temperature favors the development of other acids not favorable for the production of fine flavored butter. When lactic acid in cream has developed to about .50 or .55 per cent acidity, it should be cooled 
to about $50^{\circ} \mathrm{F}$. unless it is to be "hurned at once. The temprature of $50^{\circ} \mathrm{F}$. practically stops the development of lactic acid. Ilowever, when erram is held over night acidity will drvelop very slowly and by churning time the "ream will hav" the necessary acidity. The higher the acidity in cram the lower should be the temperature to which it should be cooled and the sooner should it be churned. If it should happen that cream gits over-ripe, cool it immediately and ehurn it two or three hours after cooling. If it is impossible to churn so soon after cooling, dilute the cram with clean, cold well water, hold at a low trmperature and churn as soon as possible. Add a littl' salt to the eream and stop churning when the stage of fine granules is reached. Wash twice with cold water, to which has been added 1 per cent of salt and have the churn in fast gear while washing. Salt and work butter as usual.

189. Coarse flavor. ('oarse flavor in butter may be caused by faulty methods in the handling of the cream or the starter, or both. It may also be the result of using poor milk or cream. When sweet, sour, musty, and unclean cream are mixed, a coarse flavor is noticeable in the butter "ren though the cream has been well cared for. Also wh'll a variety of differently soured and flavor'd rrams are mixerl, the result is usually a coarse flavor in the butter. Improperly ripened cream may also "ause a coarso flavor in the butter mad" from it.

The creameryman should try to get milk or eream of a uniform acidity and quality, and should not ripen the cream to too high aridity, nor hold it at, 
a high temperature after ripening. It should be stirred frequently during ripening and should be cooled to $50^{\circ} \mathrm{F}$. as soon as ripe. An over-ripe or off-Havored starter should never be used.

190. Unclean flavors. These flavors are usually the result of using unclean (Hunziker*) milk or cream, for which the patron is to blame, and of insanitary conditions at the creamery, for which the creameryman is to blame. Leaky vats, leaky starter cans, unclean churns and dirty conducting pipes are a frequent source of this trouble. Impure water used for washing both creamery utensils and butter has been known to cause this flavor in the butter.

Unclean flavor in butter may be prevented by stopping all leaks in vats, pipes, and starter cans and by using only good, clean water for washing utensils and butter. The creamery should be kept in first class sanitary condition. If cream has this flavor, it should be churned to fine granules, washed twice with water to which has been added 1 per cent of salt and salted a triffe heavily.

191. Curdy flavor. This is quite a common defect in butter in hot weather and is usually due to a high yer cent of acidity in hand separator cream and the effect of the intense heat on the cream during transportation. Other causes of eurdy flavors are: The pasteurizing of sour cream at a high temperature and the use of an over-ripe starter. Highly ripened cream, if overchurned may also produce curdy flavors, due to the enclosure of an excess of casein.

* Hunziker, Otto H., The Care and Handling of Milk, Bul. 203, 1902, Ithaca, N. Y. 
To overcome such faults, pasteurize high acid cream very carefully and dilute it with good, sweet milk or a good heavy starter, after. the cream is cooled for ripening. Do not ripen such eream high, nor keep it long after it has been ripened before churning it. Do not use over-ripe or curdy starters. High acid cream should always be strained before putting it into the heating compartment of the pasteurizer as this will prevent undue curdling of the casein. The addition of a little viscogen or lime water will neutralize the acidity and the temperature should be watched carefully during pasteurization. After churning, a little salt added to the wash water will aid materially in ridding the butter of this flavor. If about $1 / 2$ per cent of salt is added to the cream it will cause the butter to come in well defined granules.

192. Specks in butter. There are a number of faults in butter which the creamery operator cannot prevert, but whenever specks appear in the butter, we must give most of the blame to the man in charge of the butter making. Specks are due to the incorporation of pieces of coagulated casein and can be prevented by carefully attending to all details pertaining to the handling and ripening of cream. Over-ripe cream, when not well strained and which has not been carefully pasteurized, may cause specks in the butter. By the improper application of heat, the casein coagulates into fine granules and some of these granules find their way into the butter. Cream should always be well stirred and strained before churning. 
Specks in butter can be prevented by not overripening the cream and by frequently stirring the, cream during ripening. Cream should always be strained into the churn through a fine sieve. If (ream is very sour and lumpy, it should be well stirred and strained before pasteurizing and when pasteurizing this kind of eream it should be heated very quickly. Slow heating is likely to cause the casein to curdle. This eream should be churned at a low temperature to fine granules and 2 per cent of salt and 10 per cent of water should be added as soon as the butter "breaks." It should then be churned until the granules are well defined, and the buttermilk drawn off in the usual way. Water should then be run into the churn until it is half fall, and drained off. This should be done several times, until all casein is removed. In extreme cases it may be necessary to float the butter by filling the churn half full of water and allowing the casein to sink. The butter should then be removed to tubs, the water drawn off, the churn washed and the butter put back into the churn and worked in the usual way.

\section{PART III.}

\section{Butter Faults Due to Faulty Workmanship.}

193. Leaky or slushy butter. This condition in butter may be caused by not cooling the cream sufficiently before churning, or by churning it too soon after it is cooled. It may also be caused by washing the butter with too warm or too cold water. When the wash water is either quite warm or quite enld 
in relation to the butter, and is not left on the butter long anough to temper the buttre fat to a uniform ronsistrncy, it may "anse the butter to be loaky or slushy. A variation in the firmness of the butter granules causes the harder particles to rub on the softer ones, and this friction injures the grain and causes the moisture to appear in large drops loosely held by the butter fat. Slushy butter is more likely to appear in the spring than at any other time of the yrar', berause butter fat is naturally more soft in the spring. 'The cream therefore needs to be coolad to a lower fomprature, in order to get the same results, than it does at any other time of the year.

To prevent a leaky or slushy condition in butter. the cream should be cooled to at least $50^{\circ} \mathrm{F}$. in spring and summer. and to $54^{\circ} \mathrm{F}$. in fall and winter. The cream should be held at this tomperature for not les then three hours before churning. Where there is much trouble with soft and leaky butter, esperally in the spring, the cream should be cooled to $48^{\circ} \mathrm{F}$. and held at this temperature for some considarable length of time-proforably over night-before churning. The butter should be washed with water having a timperature of about $52^{\circ} \mathrm{F}$. and the working don' in several operations. This has a Lendency to make the butter firmer during the incorporation of the walt. If the butter is too soft at the crul of churning it ean be hardemed by allowing it to stand in cold water for tern or fifteren minutes. During this time, the ehurn should be given at fow revolutions in slow gear. The water should the'n be draines off and the butcer allowed to stand for an- 
other fifteen minutes before salting and working it. This is done to allow the coolness in the churn, and the coolness of the outside particles of butter, to penetrate uniformly through the whole mass of but1 ( $\mathrm{r}$. This prevents the moisture appearing in large drops; unevenly distributed through the butter.

194. Gritty butter. The main cause of gritty butter is, too dry, too cold, or too much salt, in connection with too cold or too dry butter fat. Other causes are: Insufficient working, and draining too dry before working. This condition may be prevented by moistening the salt before putting it on the butter; and by leaving enough water in the churn to dissolve the salt. while it is being incorporated. The wash water should be tempered in order to give the butter the proper consistency for retaining the salt and dissolving it. The butter should not be allowed to stand long before salting and working, as this will clrain it too dry and cause it to get hard. Mard, dry salt, which has not been warmed nor moistened before adding it to the butter is a frequent source of trouble. Cold salt is also very frequently the cause of gritty butter.

195. Mottled butter. Next to poor flavor in butter, mottles are most objectionable to the consumer, since they affect the appearance, and often give the impression that the butter is very bad, when, in reality, its flavor may be good.

This defect may be caused by insufficient working of the butter, by an uneven distribution of the salt. by an excess of casein in the butter, and by sudden changes of temperature of the butter, due to tron 
cold or too warm wash water. Mottlis are also caused by over churning, thus enclosing an rxcess of buttermilk and making it difficult to uniformly incorporate the salt. Too little washing, when the butter is soft. favors mottles, because the buttermill is not sufficiently removed. IIard butter mast be worked more than soft butter, and a small quanti!y more than a large quantity. Butter should be of uniform consisten'y or softness before the salt is added. Hard, dry salt should not be put on butter; it should always be moistened before adding it to the butter. Draining the butter too dry, or letting it stand until it sets or hardens in the churn, before adding the salt, should always be guarded against. The butter should not be overchurned, the workers should be set properly and the butter should bo: washed sufficiently. The butter should be in a soft. rather than a hard condition when salted, and th"r' should be sufficient moisture in the rhurn.

196. Salvy and greasy butter. These faults in butter are more common during warm wather than during the colder seasons of the year, and are most frequently met with during the hot, dry months. This condition occurs more frequently in butter made from hand separator cream than in butter made from whole mille cream. This may be mainly due to the difference in the care of both the milk and the cream at the farm, before being lolivered at the factory; but it is somutimes due to the care the cream receives at the factory. When whole milk cream butter is salvy or greasy it is quite certain that the main cause of this condition is neglort on 
the part of the butter maker to take proper care of the cream before churning, and to properly adjust the temperature of the crcam at the time of churning. If the temperature of the wash water is not in proper relation to the temperature of the butter, and if the working is performed without taking the condition of the butter into consideration, a salvy or greasy condition of the butter is likely to be the result.

When butter is made from hand separator cream, and upon examination is found to be salvy or greasy, it is not always the fault of the butter maker. Hand separator cream is often handled in such a way before it is delivered at the factory, that its condition is such as to render it impossible to make any other than salvy butter from it. However, this condition in butter may be caused by improper methods in performing the following operations at the creamery: (a) Pasteurization of cream, (b) churning of cream, (c) washing and (d) working of butter.

(A) Pasteurization. The pasteurization of very rich cream is sometimes the cause of salvy or greasy butter. This may be due to any or all of the following: Heating the cream too slowly, heating it too high and not cooling it quickly to $70^{\circ} \mathrm{F}$. or lower, after pasteurizing: Cream may be heated to $200^{\circ}$ F. without injuring the guality of the butter made from it, provided that the heating and cooling are done properly and quickly.

The poorer the cream is in buttel fat, the higher may be the temperature during pasteurization and 
the longer may the heat br applied, before such 'ream will produce salvy or greasy butter. Rich cream, however, ought to be quickly heated and quickly cooled.

(B) Churning of cream. The cream should be churned at a temperature that will favor the formation of ragged and irregular butter granules. Any other condition of the buttre granules at the end of churning, has a tendenc $y$ to create an imperfect condition in the body and grain of the butter. Churning too long favors salvy or greasy butter, due to the continued friction of the granules during churning. When cream churns too quickly, due either to high fat content or to high temperatures, the butter is inclined to be weak in body. Churning cream at reasonably low temperature is not the only means of insuring firm bodied butter. The butter fat globules must be subjucted to a certain amount of concussion. This (according to scientists) solidifies the fat globules. Thes's globules are supposed to be in a liquid or semi-liquid state in the milk and cream, even when subjected to a temperature nearly down to the freezing point. Very rich eream is more likely to produce salvy or greasy butter than is thin cream. This seems to be due to the fact that very rich eream thickens so much during churning that the fat globules are not subjected to the necessary amount of concussion and therefore the butter may contain some simi-liquid fat globules.

(C) Washing the butter. Too cold wash water may produre a salvy or greasy butter, by undue chilling of only a part of the butter granules. This 
creates an uneven consistency of the butter fat, and during working. the firmer parts eause greasiness by friction on the softer butter. Too warm water also catises the butter to become greasy or smeary, and no amount of care alter the butter is in this condition will bring it back to its normal state. Churning butter in the wash water too long tends to breale the grain, and produees a soft, salvy butter.

(D) Working the butter. When butter is in a soft condition whin worked, the fat acquires a greasy consisteney. When butter is too hard, it requires such an amount of working, that the grain is apt to be broken, giring the butter a salvy or 1allowy body. Another cause of this defect in butter, and one usually met with in the small creamery, is the practice of leaving the butter in the churn some length of time before giving it its final working. The outside of the mass of butter becomes soft in summer. and when the butter is worked, a greasy bodied butter is the result.

197. Oily butter. This butter differs greatly from salvy or greasy butter. When butter is spoken of as being oily, the impression received is that of oil mixed with butter. When butter of a perfect grain melts in the mouth, it does not have the characteristics of oily butter, although it is in one sense oil. After butter is once melted, it appears oily and no doubt. most of the oily flavor in butter is due to the butter granules which have been churned during the transportation of milk or cream, being melted or heated during the manufacturing processes. Butter may, however, acepuir' an oily favor when over- 
heated luring transportation. Very rich eream, pasteurized and not cooled to a sufficiently low temperature before churning, is likely to produce oily butter. Conn, in Iractical Dairy Bacteriology, Chapter 9, page 219, says: "An organism capable of produeing an oily effect on the butter, which is very common in Denmark, and produces considerable loss, has been discovered and studied by Jensen. It is an acid organism which curdles milk readily, but when growing in cream develops peculiar characteristics which give a strong, unpleasant taste. The result upon buttror is quite disastrous."

When very. rich cream (33 to 40 per cent) is churned at a temperature which causes the butter to come very quickly, the fat globules are not all sufficiently solidified, and the butter is apt to have a slightly oily flavor. This can be prevented by cooling the cream low enough and holding it long enough before rhurning. The richer the cream, the longer it should be held cold before churning, and the lower should the temperature be.

W. Fleischmann, Pl. D., in The Book of the Dairy, says, on oily butter:

"Churning very rich cream above 32 per cent butter fat.

Very rich cream may easily cause oiliness in butter from the following causes:

1. Not cooled low enough before churning even though the cream is held over night.

2. By churning too fast and thereby not giving the fat time enough to solidify during the act of rhurning. 
3. Pasteurized rich cream must be cooled lower than unpasteurized eream of the same richness."

My practical work and observations in creamery butter making agree with the findings of Dr. Fleischmann. I have noticed repeatedly that when cream testing above 33 per cent was churned. the butter easily took on a greasy texture.

In paragraph 197 will be found an explanation of conditions that may cause oily butter.

198. Woody flavor. This flavor may be imparted to butter by a leaky vat (the water which surrounds the vat leaking into the cream) or by a new churn which has not been sufficiently washed and soaked with hot water before being used. It may also be caused by an old churn not being rinsed bcfore the cream is put into it. A new churn should be washed several times with hot water in which sal soda has been dissolved. After each washing with hot water, the churn should be cooled by washing it with cold water. When buttermilk can be had, it is a good plan to churn buttermilk in the new churn for half an hour. Buttermilk or sour milk will absorb woody taints from the churn more quickly than water will

199. Lardy or tallowy butter. Conditions which produce lardy or tallowy butter are not definitely known. These defects may appear at any season of the year, but most frequently make their appearance during cold weather. The reason for this may be, the use of too cold wash water and washing the butter too much, when cream has been churned at a comparatively high temperature. Certain dry 
fereds maly have a temdency towarel producing this defect in butter, but as yot it has not beran definitely dotermined just what aomlitions ar" responsible for it.

200. Fishy flavor. This very objoctionablo flavor serems to appear most frecuently in butter made from over-ripe, old and unclean milk or "rram; "specially if it is delivered in old and dirty cans. In one instance fishy flavor disappired upon the improvement of sanitary eonditions under which the milk was proluered and delive?er!, as well as the conditions under which the butter was made. From this it would serm that alannlinesu has a greal effecet on the extent of the appearane of this flavor. It is the opinion of some prople that wilt favors the jroduction of fishy flavor in buttor, but there seems to be very little doubt that it is due to unclean milk or cream, and the extent to which it may develop is in proportion to the "xtent to which the milk or cream is contaminated. It is possible that fishy flavor is due to by-products of certain undesirable bacturia. These by-products, when combines with lactice and and salt, may produe this flavor. It has been noted that dirty milk eans, asperially when the iron is expersed to the aretion of acid, have alused the appearane' of fishy flavor.

201. Brittle butter. This is not a common defrect in butter, and is known to appos more frequently in some localitios than in others. Excessive feeding of beet leaves has been known to proluee a britte body in butter. Washing butter in very rold water has a tendeney to make it dry witls a slightly brittle 
body. The use of very high teriperatures in the pasteurization of eream is also thought to have been the cause of brittle butter. By carefully attending to all the different processes in butter making, and properly adjusting the temperatures used in pasteurizing, ripening and churning the cream, and washing the butter, this kind of butter may be avoided.

202. Unclean flavor. The expression "unclean" is very commonly used in describing taints which are hard to classify. Unclean flavor may be the result of various causes, and may originate in contamination from impure air, impure water, insanitary utensils used in the handling of the cream, or unclean machines used in the manufacture of the butter. Unclean flavor in butter simply means that at some stage in the handling of the milk or cream, or in the manufacture of the butter, insanitary conditions existed. These conditions must be improved before this flavor can be done away with. Instances are common where this Havor is due to the water used at the creamery. The butter is apparently good when very. fresh, but soon after being placed on the market, a disagreeable, unclran flavor develops.

203. Coarse flavor. A coarse (189) flavor in butter is usually the result of high ripening of the cream, and too little washing of the butter. High salting seems to bring out the high acid flavor, and these two (high acid and salt) combined with a leaky bodied butter, produce a very coarse flavor, which is decidedly objectionable to the palate. The use of an over-ripe starter also has a tendency to produce coarse flavored butter. 


\section{CHAPTER XI.}

\section{THE ART OF BUTTER JUDGING.}

Flavor should be rich, pleasing, creamy and should suggest nothing objectionable to either the taste or smell.-

MATH MICHELS. 


\section{INDEX TO CHAPTER XI.}

Par. No.

Page.

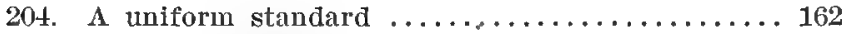

205. Personal preference .................. 162

206. Ability of judges $\ldots \ldots \ldots \ldots \ldots \ldots \ldots \ldots \ldots \ldots$

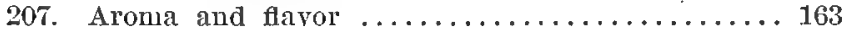

208. Body of butter . . . . . . . . . . . . . . 164

209. Appearance of the drawn plug............ 164

210. Regarding color of butter............. 165

211. Regarding specks in butter............. 165

212. Regarding salt in butter.............. 165

213. Regarding briny and leaky butter..........166

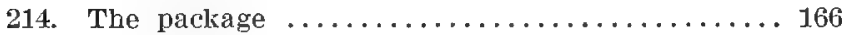

215. American standard for scoring butter........ 166

216. Relative scoring of butter............. 166

217. A table showing relative defects in butter..... 167

218. Classification of butter necessary for accurate point scoring ................... 168

219. The value of discussiing and comparing scores by judges .......................... 169 


\section{CHAPTER XI. \\ The Art of Butter Judging.}

204. Classifying butter has been customary ever since butter was manufactured for commercial purposes. Since people have trained themselves to pass judgment on butter in accordance with certain standards of excellence, butter judging has become both a science and an art.

Different markets in the United States demand butter of about the same standards of perfection except in color and salt. This is due to the demand of some local markets. Since the variation in the standards of the different American markets are very slight, butter judges do not find it very difficult to score butter satisfactorily in any state.

205. Personal preference. That individual tastes vary and that standards of individual preference are widely diverse are well known facts. Since flavors affect the palates of some persons more than others, no two persons, however acute their senses, can always score the same butter alike; nor can one judge always give the same butter exactly the same score even though the scorings are not taken far apart. Individual peculiarity is responsible for the difference of opinion relative to certain defects in the flavor and aroma of butter. Since some defects in butter appear more pronounced to one person than to another, a variation in the score of the same butter by different judges is inevitable. 
206. Butter judges born not made. The faculty of judging butter accurately and uniformly is an art-a gift of nature, though often perfected by training. No amount of training will mako an expert butter judge unless nature has contributed her share of those qualities necessary for the proper performance of this art. In view of the difficulty of a judge giving the same decision on the same butter with no small variation it is necessary if it can be so arranged to have more than one jurge for scoring the same lot of butter. This view is recognized by those in charge of scoring exhibitions and more than one judge is usually employed for such work.

207. Aroma and flavor. Aroma in butter is that quality which is detected only by smell, while flavor refers only to the taste of butter, although both terms are not generally accepted in this light. The quality of the aroma is not always a true indication of the quality of the flavor, although to a great extent the flavor can be fairly well judged from the quality of the aroma. Having determined the defects found in the aroma, the judge must taste the butter in order to determine the defects existing in the flavor. The aroma and flavor are very closely related. In the aroma are found characteristies due to bacterial fermentation and to chemical changes, while in the flavor are found both mechanical and physical characteristics as well as some of the defects found in the aroma. Contamination, due to insanitary handling of the eream, may manifest itself either in the aroma or in the flavor or in both, depending upon the nature of the contamiuation. 
208. Body of butter. By carefully watching how the trier passes into the tub and how it pulls from it, the body of the butter can to a great extent be determined. Then by gently pressing the plug with the thumb and eritically noting the appearance of it, mechanical defects may be ascertained. When butter is greasy, due perhaps to overchurning, overworking or washing in warm water, and if the back of the trier is greasy and the plug appears smeary, as a rule, the flavor and aroma of this type of butter are poor. A defect in body means a fault in the aroma or flavor or both. Overworked, greasy, mushy butter deserves to be severely criticized, as it is within the power of the butter maker to prevent these defects. Such defects are primary causes of developing staleness and rancidity in butter. The breaking of the grain in butter is usually accompanied by a characteristic greasy flavor and a low, flat aroma. The destruction of the grain in butter affects the aroma and destroys the "bouquet" quality so much sought.

209. Appearance of the drawn butter plug. The plug from a first class piece of bntter should have a glossy, smooth, clean cut appearance and should be beaded with minute drops of water. If the plug is beaded with large drops of water which trickle down and drop off when the plug is withdrawn the butter is, as a rul', leaky and may be lacking in the fin' ${ }^{\prime}$ qualities of aroma and Havor. On the other hand when the plug is greasy, dull and very dry in appearan'", the aroma and flavor may be of a disagreeable character and are likcly to be of an oily 
and greasy nature. The broken end of a plug of butter should have a granular appearance, with small drops of water glistening among the granules at the break. When the plag of butter splits easily upon being pressed between the finger and the trier, the butter has not been sufficiently worked or else has been worked at too low a temperature. Such butter is inclined to be mottled. Mechanical defects of this kind should be severly criticized and the cause and remedy for such defects should accompany the score.

210. Coloring butter. Butter is colored as a rule according to market demands. Some butter houses as well as some consumers, demand a very deep color, while others demand a very light colored butter. Butter judges do not find fault with a very slight variation from a normal shade, but they do find fault with too great a variation from the normal butter shade. All abnormal variations in the depth of the color of the butter should be criticized. Streakedness is one of the greatest faults of butter, and a reduced score is always given when butter is badly mottled. This fault has in many cases been the cause of heavy financial losses to the creameryman because consumers object to mottled butter.

211. Specks in butter. Specks in butter are not due to faults in the process of manufacturing the butter, but are due to faulty crcim ripening and to improper straing of the cream. This fault is always severely criticized because of the nature of the cause.

212. Salting. Grittiness in butter is a great defect; butter judges and butter buyers do not like butter 
which is gritty. Therefore in jurging butter the degree of grittiness has a great influence on the final score. This effect can be easily remedied.

213. Briny and leaky butter is usually caused by working the butter under abnormal conditions, and they usually go together. The walt should always be well dissolved and evenly disl ributed. Uniformity in salting butter is very much liked by dealers, as well as consumers.

Excessive brine in butter partly destroys the fine aroma, injures the flavor, lowers the score and reduces the commereial value of butter.

214. The package to be perfect, should be n'int and elean. The butter should be even with the top of the package, and the liner should be turned onto the butter about one inch. A cloth with a little salt should be on top, and a parehment circle should be on top of this. Tacks used for tagging should not renetrate into the butter, as they leave rusty spots on it. The hoops should be all on the tub and the tin cover fasteners should be properly attached

\section{Butter scoring. American standard.}

Flavor--45. Fairly pronounced, sweet, clean, nut$1 y$, aromatic and full of character.

Body-25. Waxy, grainy, firm, smooth, close and glossy.

Color-15. Even, natural and neither too high nor too low.

Salt-10. Mrdium, well dissolved and fairly briny.

Package-5. Noat, clean and full package.

Total 100 points. 
216. Relative scoring of butter. On a scoring blank we find that the number of points allowed on package is 5 , while on flavor it is 45 , or nine times the value placed on package. If we score off one-half point on package, we must score off about 4.5 points on flavor, if the flavor shows the same degree of defect as the package shows. If the body, which carries 25 points as a perfect score, shows a defect sufficient to reduce the score $21 / 2$ points, we must, if the flavor shows a defect which would take $1 / 10$ off the perfect score, take off $4 \frac{1}{2}$ points on flavor. This constitutes relative scoring and is the only way to score butter. In scoring, we must bear in mind that when the package is only very slightly defective, we should not score off one point and at the same time score off only four points for a vory defective flavor.

I wish to bring out the basis of comparison upon which the scoring of butter should be performed, and trust that it may establish in the minds of creamery operators a clearer conception of the principles involved in scoring butter. Suppose that we have a tub of butter where the flavor, body, color, salt and package are all slightly defective. In order to show more clearly how it should appear when tabulated, the following table is prepared.

\section{Relative score.}

\begin{tabular}{cc|c|c}
\hline \multicolumn{2}{c|}{ No. Points Full Score } & Scored Of̈ & Final Score \\
\hline Flavor & 45. & $41 / 2$ & 40.5 \\
Body & 25. & $21 / 2$ & 22.5 \\
Color & 15. & 1.5 & 13.5 \\
Salt & 10. & 1 & 9.5 \\
Package & 5. & $1 / 2$ & 4.5 \\
\hline & 100. & & 90. \\
\hline
\end{tabular}




\section{Classification of butter necessary for accurate point scoring.}

218. During two years as one of the butter judges appointed by the University of Wisconsin Dairy School to judge the butter at the monthly exhibitions at that school, and also while instructor in dairying at the same time, some jdeas came to me which might, perhaps, be used in the scoring of butter to increase the value and aceuracy of scoring by "points."

Judges who are at all acute find it difficult to give butter scoring 96 points, the proper score, when preceded by a package scoring 80 points; or on the other hand when the first tub scored 95 points and the one following scored 82 points. The butter which was scored 82 after scoring the 95 point butter, should perhaps have received a score of 83 or 84 , but the contrast between the two tubs was so great that the butter seemed rially poorer than it was. We must admit that we score to some extent by comparison as well as by a definite standard. Therefore it is plain that the greater the difference in the quality of butter in the rlifferent packages, the greater are the chances for inaccuracy in scoring. It stands to reason that the smaller the variation in quality in the successive packages the more uniform can the scoring be. If this were not so, why should a "shake down" be considered necessary for the placing of the final and rightful score on a number of the highest scoring packages The principle involved in the "shake down" is the same 
as that in scoring by point-each class or grade by itself. The greater the knowledge we gain in scoring butter and the higher the grade of work we can do, the nearer we approach the system of scoring by points first being classificd or graded. Or in other words the "shake down" principle is carried through the whole scoring of bulter.

\section{The value of discussing and comparing scores by judges.}

219. Depriving judges of the right to discuss and compare scores after a number of tubs have been judged, seems like proclaiming that people are infallible in their judgments, ani in their likes and dislikes. It also means that butter judges can set a certain standard of their own and carry this through the process of scoring one hundred or five hundred packages of butter without variations.

The. discussing and comparing of scores is necessary if the work executed is to he of high class. It sharpens the sense of proportion and relative analysis of faults in butter. It gives confidence to the judges in their future work, and acts as a guide and a check on one's own judgment. It curbs assertiveness, positiveness and conceit in one's own decisions. 


\section{CHAPTER XII.}

\section{PASTEURIZATION.}

Oh! There is a rieh field indered

for investigation.-

IOUSS PASTEUR.

\section{PASTEURIZATION OF MILK AND CREAM FOR CITY SUPPLY.}

While the process (pasteurization) is not an absolute protection against digastive troubles it is to-day roognizorl as a usceful means of rorlucing them.-

II. W. CONN. 


\section{INDEX TO CHAPTER XII.}

I'atr. No.

Page.

20. (.) Pasteurization of cream for buttermaking.. 173 ‥21. Pasteurization conducive to better methods..... 174 2.2. Preparing cream for pasteurization.......... 175 ב2:. Mixing of sweet and sour cream........... 175 224 . The use of viscogen in pasteurization........ 176

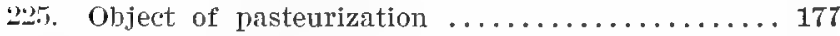
2.6. Heating and cooling the cream........... 177 ...T. Using intermittent pasteurizers ........... 178 … Some investigations ................ 179

(a) Do you favor pasteurization of cream for buttermaking? ................... 179

(b) Do you think that pasteurized cream will produce better and longer keeping butter than raw cream? ................... 179

(c) Do you believe that hand separator cream should be chtorned soon after delivery?.... 180

(d) What is the best temperature at which to pasteurize cream?................. 180

Tubercle bacilli in market butter........... 181

2.9. Importance of aeration of cream during pasteurization or ripening ................ 182

230. Conditions on dairy farms not yet ideal...... 182 231. Physicians adrise pasteurization........... 183 2:3. Pasteurization not intended to cover up faults.. 183 233. New methods opposed ................ 184 234. Market milk should be pasteurized.......... 185 235. Bacteria in market milk............... 185 236. Bacteria before and after pasteurization....... 186 237. Results of continuous pasteurization of milk.... 186 Table XIV. and XV. 


\section{CIIAPTER XII.}

I'ar'. No.

Page.

238. I vevelopment of barteria in milk.......... 187

239. Care and rleanliness in handling milk....... 188

240. Clarification and separation ........... 189

241. The grading of milk................ 189

24 . Variation in test of cows' milk........... 190

243. Table showing variation in test........... 191

244. Variation in tests, as found by C. O. Jensen..... 192

245. Temperatures for pasteurization ........... 192

246. Temperatures recommended by Jensen and

I'latner ...........................193

247. Intermittent system of pasteurization........ 194

248. Advantages and disadvantages of intermittent

systems ....................... 194

249. Regarding continuous pasteurizers .......... 195;

250. Regarding semi-continuous pasteurizers ...... 195

251. Cleaning pasteurizers ............... 196

252. Prejudice against pasteurized milk and cream... 196

25i3. Sources of bacteria in milk............ 197

254. Epidemics caused by raw milk. . . . . . . 197 


\section{CHAPTER XII.}

\section{Pasteurization.}

220. (A) Pasteurization of cream for butter making. Even though the commercial score were the same in both pasteurized and unpasteurized butter of a certain age we would still teel inclined to believe it a fact that the butter made from pasteurized cream is essensially the better butter. Pasteurization of cream does not add any flavor to the butter made from it, but pasteurization has the faculty of refining all flavors whether good or bad in cream, and the process of heating and conling drives off impure odors. It also materially lessens obnoxious fermentations and renders the cream safe from the evil effects of disease producing organisms. Not only this, but pasteurization (Slater*) also imparts keeping qualities to milk and through 1 his to the butter made from it (Dean $\left.{ }^{* *}\right)$. Trials have been made comparing pasteurized and unpasteurized cream butter made from the same lot of cream, both being held at a temperature of $65^{\circ} \mathrm{t} n 75^{\circ} \mathrm{F}$. and it was found that the pasteurized cream butter remained in good condition twelve days longer than did the butter made from unpasteurized cream.

Considering the pasteurization of cream for butter making in its broadest sense, I am fully convinced from results obtained by men engaged in pas-

* Slater, E. K. Wisconsin Buttermakers Association, Feb. 1904, Third Annual Report, page 122 .

* Dean, H. H. Modern Dairying. Kansas State Board of Agriculture; Sept. 30, 1903. Vol. 23. 
teurization as well as from my own personal expericnee that pasteurization of cream for butter making is correct in principle and sound in application under present dairy conditions.

221. That pasteurization favors slack and insanitary methods in the handling of dairy products (Rogers*) does not coincide with the methods employed in pasteurjzation plants nor does it agree with the fact that wherever pasteurization is employed, more export service is necessary and better methods are invariably employed. The fact that men of higher caliber are employed means the adoption of better methods all along the line, from producer to consumer. Practice does not sustain the contention that pasteurization favors slack methods, because the poorer the quality of the raw material the greater is the loss during the manufacturing process. Pasteurization of cream for hutter making will not receive its due recognition until the fundamental principles involved in it are well understood and the methods of application rerognized as worthy of thought and study. So long as the belief exists that all there is to the process of pasteurization is the mere heating and cooling of the "ream without taking into ronsideration the quality of the eream handled, the kind of machine usct and the time it is to be heated, pasteurization will not be received with much favor by creamerymen.

Since we raunot yet hope to have swert, clean cream produced and delivered to any creamery where we have third or fourth rlass dairymen to

- Rogers, L. A. Bacteria of Pasteurized and Unpasteurized Milk Under Laboratory Conditions. U. S. Bulletin No. 54. 
deal with we must pasteurize the cream. If we had first class dairymen and were positive that all the cows were healthy, the help employed free from communicable diseases and the water pure, we might dispense with pasteurization altogether. However, as we do not have this ideal condition at present it is certainly safer to pasteurize all cream for butter making.

222. Preparation of cream for pasteurization. All cream whether sweet or sour must be thoroughly mixed before being put into the pasteurizing machine. Unless the butter fat is evenly distributed through the cream the result will not be satisfactory. When cream is sour and lumpy when received it should be strained through a wire strainer and afterward thoroughly stirred in order to break up all clots and break up the coagulated casein into the smallest possible particles. If this is not done the clots of casein when heated will curdle and form hard granules enclosing fat globules. Some of these granules of casein and butter fat will go into the buttermilk when the cream is chnrned, and some of them go into the butter. These specks of casein in the butter may cause the butter to decompose more readily and may also be the cause of reduced price obtained for butter. If an intermittent pasteurizer is used in pasteurizing lumpy cream, the granules of casein produce a sediment in the bottom of the pasteurizer.

223. Mixing sweet and sour cream. When a creamery receives a large quantity of both sweet and sour cream, these should not be mixed unless it is neces- 
sary to do so when rrom is gathered. Whenever possible each should be pasteurjzed by itself, as mixed cream burns onto the pasteurizer more easily than either sweet or sour cream when pasteurized by itself. Well ripened cream will not burn onto a disc pasteurizer, and it will not so easily burn unto any other pasteurizer as mixed ream will.

224. The use of viscogen in cream (Russell*) as a means to reduce the acidity in order that cream may be more successfully pasteurized is to be recommended. Whenever state or ferleral laws allow the use of viscogen it is well to use it. because it can be successfully used in pasteurizing sour cream.

\section{To prepare viscogen for restoring the consistency of pasteurized cream.}

Two and one-half parts by weight of a good quality of granulated sugar are dissolved in five parts of water, and one part of quick lime gradually slaked in three parts of water. The resulting milk should be agitated at frequent intervals, and after two or three hours allowed to settle until the clear liquid can be drawn off. This clear liquid (viscogen) is the part used and should be kept in well-stoppered bottles, as it loses strength and becomes dark-colored when exposed to air. The darkening in color, however, does not impair its us'fulness.

When eream is very sour and of poor flavor, more viscogen may be used than with good cream, without injuring the eream in any way. Use not more

* Russeli, H. L. Bulletin No. 54, Wis. Expt. Sta. 
than 4 percent of viscogen in eream of good flavor and high acid, and not more than $1 / 2$ per cent of viscogen in off flavored cream. Too much viscogen in cream kills the aroma and flavor in the butter made from it, and imparts a peculiar limy flavor to it.

225. Object of pasteurization. In pasteurizing we aim to destroy all lactic acid producing bacteria and as many other kinds of bacterial life, the thermal death point of which comes within the range of the heat applied. By destroying practically all abnormal fermentations and disease producing germs the cream is rendered comparatively free from germ life and in this condition the cream is in the best possible shape for controlling lactic acid fermentation and producing a high grade of butter. (Conn.*)

226. Heating and cooling. When using a continuous machine the cream may be heated to $190^{\circ} \mathrm{F}$. without injuring the flavor of the butter made from it or increasing losses in the buttermilk. The poorer the flavor of the cream the higher should be the temperature used in pasteurizing unless this cream has been heated in a separate tank to a temperature of about $125^{\circ} \mathrm{F}$. and thoroughly stirred for the purpose of removing bad odors. After pasteurizing, the cooling must be rapid and thorough. The cream should be cooled to ripening temperature unless it is rich enough to allow the addition of 30 per cent or 40 per cent of starter. If this is possible the cream should be cooled to below $53^{\circ} \mathrm{F}$. and held at a low temperature until churning time. When thin cream is pasteurized and is to be ripened, it should be cooled to

* Conn. H. W. Bacteria in Milk and its Products, 1903; Chapter 7, pages $208,213,226,228$. 
ripening temperature as it flows from the machine and the starter added at once.

Suppose a continuous pasteurizer is to be used to pasteurize very thin cream which is both off flavored and of high acidity. In this case do not run the machine at its full capacity but reduce the inflow by one-half. Raise the temperature to about $190^{\circ} \mathrm{F}$. and pasteurize as usual. Cool to below $55^{\circ} \mathrm{F}$., add as much starter as the richness of the cream will allow, hold for three or four hours and then churn. Be sure to add a good starter as this will absorb any burnt flavors and produce a fine flavored butter. (Larsen \& Shepard.*) Again, let me emphasize the fact that a large quantity of good starter is a powerful factor in ridding cream of bad odors and burnt flavors. In order to get rid of burnt flavors acquired by pasteurizing do not churn cream in onehalf or an hour after pasteurizing, but add a good starter and allow it to do its work.

227. When intermittent pasteurizers are used the cream should not as a rule have a very high acidity if good results are to be obtained. When cream has more than .4 per cent acidity the casein curdles very easily and the enclosure of fat globules is inevitable. The result will be a heavy loss in the buttermilk. The success attained in the handling of sour cream in either the continuous or intermittent pasteurizer depends to a great extent upon the skill of the operator. The continuous pasteurizer is preferable for handling hand separator cream or any cream which has developed high acid.

- Larsen $\&$ Shepard. A Study of South Dakota Butter with Suggestions for Improvement, page 467 . 
228. Investigations. Since data on pasteurization of cream for butter making is limited, and in order to prove or disprove certain opinions and the results of some investigations, letters of inquiry on this subject were sent to some of the best creameries in every dairy state in the union. The answers are based on the results of practical work and we may therefore accept, at least in part, the conclusions reached by these practical mon. Question one was:

\section{(A) Do you favor pasteurization of cream for butter making?}

A very small percentage of the answers do not favor pasteurization, but the statement is qualified by another stating that if the ernm were not of the best quality, pastemrization would be desirable. Ninety-four per cent are highly in favor of pasteurization and ten per cent of these claim that the market ought to recognize pasteurized eream butter and pay more for it. They may not, however, take into consideration the fact that the increased stability of their market is fully worth the cost of pasteurizing. Most of the answers claim that good, pure, sweet cream need not be pasteurized.

Question two:

(B) Do you think that pasteurized cream will produce better and longer keeping butter than raw cream?

Ninety-five per cent claim that pasteurization of cream increases the keeping quality of the butter made from it. Some few qualify their statements by saying that the keeping quality of butter made from pure, sweet cream is not increased by pasteurization. 
Some place great stress upon the necessity of having all processes connected with pasteurization properly handled, since if this is not done pasteurization is not of much value. Some state that their experience during fifteen years of pasteurizing cream for butter making shows that butter made from pasteurized cream had superior keeping qualities.

Question three:

(C) Do you believe that hand separator cream should be churned soon after its delivery?

Most of the answers received claim that when cream is reccived in fairly good condition it should be ripened to about .5 per cent acidity and held for at least three hours (in most cases until next morning) before churning. In case of poor pasteurized cream the adding of a heavy starter is advocated; the cream to be cooled and held for about three hours before churning. The churning of mixed sweet and sour cream soon after it is poured together is not favored, as it is claimed that losses in the buttermilk are heavier than when such eream is held for some time before churning. Due to the condition of the average hand separator cream about thirty per cent of the answers state that it should be pasteurized, quickly ripened and cooled as low as the richness of the cream would permit for proper churning. They advocate holding it for about three hours before churning.

Question four:

(D) What is the best temperature at which to pasteurize cream?

According to the answers to this question, the general opinion is that the temperature at which to 
pasteurize cream depends mainly upon the condition of the eream-that is, it depends upon the richness, age, acidity and flavor of the cream. The kind of pasteurizer used is given as another important factor influencing the temperature it which to pasteurize. The average temperaturi suggested is about $175^{\circ} \mathrm{F}$. for continuous machines and about $150^{\circ} \mathrm{F}$. for intermittent machines. No definite temperature can be recommended because in some localities the cream must be handled differently than in others.

\section{Tubercle bacilli in market butter.}

TABLE XIII.

\begin{tabular}{|c|c|c|c|c|}
\hline $\begin{array}{l}\text { Names of } \\
\text { Investigators }\end{array}$ & $\begin{array}{c}\text { No. of } \\
\text { samples } \\
\text { tested }\end{array}$ & $\begin{array}{c}\text { No. In } \\
\text { which } \\
\text { tubercle } \\
\text { bacilli } \\
\text { was } \\
\text { found }\end{array}$ & $\begin{array}{c}\text { Per. } \\
\text { centage }\end{array}$ & Remarks \\
\hline Brusafiero & $\theta$ & $\mathbf{1}$ & 11 & \\
\hline Roth & 20 & 2 & 10 & \\
\hline Schuchardt & 42 & 0 & 0 & \\
\hline Obermueller & 14 & 14 & 100 & Obtained from one source. \\
\hline Groelng & 17 & 8 & 47 & \\
\hline Petri. & 102 & 33 & 32 & From Berlin and Munchen. \\
\hline Roblnowitsch & 80 & 0 & 0 & $\left\{\begin{array}{l}\text { 3n samples from Berlin. } \\
\text { I } 50 \text { samples from Yhiladelphia. }\end{array}\right.$ \\
\hline $\begin{array}{l}\text { Hormann and } \\
\text { Morgenroth }\end{array}$ & 10 & 3 & 30 & \\
\hline Roblnowltech & 16 & 2 & 13.3 & Obtained from 14 shops. \\
\hline Korn & 17 & 4 & 23 & Obtained from 22 shops. \\
\hline Ascher : & 27 & 2 & 7 & \\
\hline Weisenfeld & 32 & 3 & 9 & \\
\hline Hellstrau & 12 & 1 & 8 & \\
\hline Bonboff & 89 & $\mathbf{0}$ & 0 & \\
\hline Marke & 49 & 0 & 0 & \\
\hline Augeszky & 17 & 8 & 17 & \\
\hline
\end{tabular}


The above results were taken from Swithinbank and Newman. Bacteriology of Milk, 1903.

It is remarked that perhaps not all bacilli found in butter were tubercle bacilli. S'till pasteurization of cream would make butter safe.

229. Importance of aeration of cream during pasteurization or ripening.

The aeration of cream plays a very important part in ridding it of bad odors and in facilitating the production of fine flavors. The bunefits derived from proper acration are underestimated by creamerymen at the present time. The circulation of pure, fresh air purifies both milk and cream; therefore aeration must be done in pure air, or the cream will absorb instead of giving off odors. Whenever the air is purer than the milk or cream, good will be accomplished by aeration, (specially during pasteurization of either milk or cream to be used for butter making.

\section{(B) Pasteurization of milk and cream for city supply.}

230. Experiences and opinions of different authorities vary with regard to the benefits derived from pasteurization of milk and cream for city supply. l'uxley in Modern I)airy Farming, "hapter VII., page 83 , says :

"Wire that every precaution is taken to kre'p the milk absolutely pure as it romes from the cow; rleanse rvery utronsil amployed in the handling of milk thoroughly by scalding with steam or boiling watur; "ool the milk 10 as nuar $40^{\circ}$ as possible before it is dispatwhed on its long journey by rail; see 
that it is delivered as quickly as possible on reaching its destination; allow no preservatives to be introduced at any time or in any quantities; and feed young infants with milk at the natural temperature and in small quantities at a time."

The average milk and cream consumer would gladly drink raw milk or cream strictly pure, if he were so situated as to be able to afford it. When milk and cream are produced under strictly cleanly conditions, drawn from healthy cows by healthy workers, the cost of production exceeds the price which the average consumer can afford to pay.

231. When children are sick and milk and cream are preseribed as a part or entire diet, and its source as to cleanliness is questioned, the attending physician invariably insists that the milk or cream be heated or pasteurized. (Doan and Price.*)

232. Pasteurization is not intended to cover up faults in cream and milk and it will never be used for this purpose by intelligent dairymen, nor is pasteurization merely a fad; if it had not filled a real and long felt want, its use would have been discontinued long ago. Instead of being discontinued it is rapidly gaining in favor and will continue to be employed until we have such well regulated dairies and such good transportation facilities, as to render it unnecessary and therefore unprofitable. Not until we can procure clean, sweet milk, which is free from disease producing germs, dare we dispense with pasteurization of both milk and cream. Pasteurization imparts to market milk and cream a fine flavor, enhances its keeping qualities, and makes it safe for

* Doan and Price, Bulletin No. 77, Maryland Station, page 10, 1901. 
infant feeding when condensed or evaporated milk cannot be used.

Even if pasteurization of milk (Marshall*) did nothing more than to kill disease producing germs (Fleischmann ${ }^{*}$ *) which may get into the milk or cream, we would feel warranted in establishing a system of pasteurization in all city milk plants.

233. Whenever anything new is introduced, it is usually received with suspicion and disfavor, regardless of its value to mankind. Instances are known where the introduction of something new, although of great value to mankind, was met with unwarranted opposition. In some ways this tendency of the public is commendable, because it acts as a check upon the introduction of useless things devised mainly for the purpose of deceiving the public. Any method, system, procedure or device which gains favor in spite of opposition must be fundamentally right. Pasteurization occupies such a place at present. It is gaining in favor among all classes of people and is of great economic value to the dairy industry today. Should the death of a person be the direct result of the use of pasteurized milk, this would be made known to all the world; but we all know that very little is said regarding all the lives that are saved by the use of pasteurized milk. It is acknowledged that the mortality in children, especially those under the age of three years, has been greatly reduced by the use of pasteurized milk and cream. Some even claim (Marshall****) that infant

- Marshall, C. E. Bacteria and the Dairy. Bulletin Fo. 46, p. 48. Mich. 1907.

** Fleischman, W. The Book of the Dairy. Chapter VI, page 276. 1896.

** Marshall, C. E. Killing the Tubercle Bacilli in Milk. Mich. Bulletin 172.173, page 321 . 1899 . 
mortality has been reduced by one-half where even only part of the city milk has been pasteurized.

Ideal conditions on dairy farms under which sanitary milk and cream can be produced at a price within reach of the working men have not yet been attained and it seems doubtful that they ever will be.

234. That all milk used for city supply not classed as eertified or inspected is recommended to be pasteurized (Govt. Bul.*), is a step in the right direction and deserves the attention of all right minded milk dealers and city officials. In the future we shall have more city officials who favor pasteurization as a legitimate means by which the public will be supplied with better and safer milk. Far-sighted businessmen recognize not only the commercial value of pasteurization but also its value as a means of prerenting tha spread of discase. Nathan Strauss says: "I consider pasteurization of the milk supply-and the great majority of the scientific world agrees with me-one of the most important weapons in fighting the white plague."

235. Bacteria in market milk. In fifty-seven samples of Boston milk, Sedgwick and Batchelder found from 30,000 to $4,220,000$ bacteria per cubic centimeter. Hill and Slack on examining 2,394 samples, nearly all taken as the milk arrived in the city, found that 42 per cent of the milk contained less than 100,000 bacteria per cubic centimeter; 29.75 per cent contained between 100,000 and 500,000; 12.75 per cent contained between $1,000,000$ and $5,000,000 ; 9.75$ per cent contained between 500,000 and $1,000,000$; and 5 per cent contained above

* Government Circular 114, page 7. 1907. 
5,000,000 bacteria per cubic centimeter. Some samples of milk taken in New York, at the time of its arrival there, were found to contain $15,163,600$ bacteria per cubic centimeter.

236. Bacteria before and after pasteurization.

That raw milk contains a large number of bacteria will be seen from the following table (Rogers*) :

\section{TABLE XIV.}

Average Number of Bacteria per Cubic Centimeter in all Samples Under Each Treatment.

\begin{tabular}{|c|c|c|c|c|c|c|c|}
\hline \multirow{2}{*}{$\begin{array}{l}\text { Description and treat- } \\
\text { ment of sample. }\end{array}$} & \multicolumn{7}{|c|}{ Number of bacteria after the lapse of -} \\
\hline & 0 hours & 6 hours & 12 bours & 24 hol & 48 bours & 72 hours & $\longdiv { 9 6 \text { hours } }$ \\
\hline $\begin{array}{l}\text { Raw milk kept at } 20^{\circ} \mathrm{C} \text { - } \\
\text { Pasteurized milk kept at } \\
20^{\circ} \mathrm{C}\end{array}$ & & 74,14 & $247,651,250$ & 457,0 & $608,079,166$ & 568,7 & \\
\hline $\begin{array}{l}\text { asteurized milk kept at } \\
10^{\circ} \mathrm{C}\end{array}$ & 245 & 308 & 106,785 & 1,026 & 15,119 & $2,462,492$ & $37,088,450$ \\
\hline
\end{tabular}

237. Results of continuous pasteurization of milk at $140^{\circ}$ to $160^{\circ} \mathrm{F}$., or $60^{\circ}$ to $63^{\circ}$ centigrade. (Dean and Harrison.***;

TABLE XV.

Thirtecn Tests, Percentage of Bacteria Killed, 96.42.

\begin{tabular}{|c|c|c|c|c|c|}
\hline \multirow[b]{2}{*}{ Date } & \multirow[b]{2}{*}{$\begin{array}{l}\text { Pagteuriz- } \\
\text { Ing tem- } \\
\text { perature }\end{array}$} & \multirow{2}{*}{$\begin{array}{c}\text { Tempera- } \\
\text { ture of } \\
\text { milk before } \\
\text { pasteurizing }\end{array}$} & \multirow[b]{2}{*}{ Acldity } & Unpasteurized & Pastearlzed \\
\hline & & & & $\begin{array}{l}\text { Average No. } \\
\text { of germs } \\
\text { per c. c. }\end{array}$ & $\begin{array}{c}\text { Average No. } \\
\text { of germs } \\
\text { per c.c. }\end{array}$ \\
\hline $\begin{array}{ccc}\text { Aprll } & 10 \\
\text { “ } & 12 \\
\text { Mag } & 15 \\
\text { “ } & 4 \\
\text { “ } & 18 \\
\text { “ } & 21 \\
\text { " } & 27 \\
\text { “ } & 29 \\
\text { June } & 3 \\
\text { " } & 6 \\
\text { “ } & 8 \\
\text { Aug. } & 5\end{array}$ & $\begin{array}{l}146 \\
140 \\
142 \\
144 \\
140 \\
140 \\
140 \\
140 \\
140 \\
140 \\
140 \\
140 \\
140\end{array}$ & $\begin{array}{l}54 \\
52 \\
54 \\
58 \\
58 \\
61 \\
61 \\
58 \\
60 \\
60 \\
58 \\
60\end{array}$ & $\begin{array}{l}.15 \\
.16 \\
.18 \\
.15 \\
.17 \\
.19 \\
.17 \\
.17 \\
.17 \\
.17 \\
.16 \\
.17\end{array}$ & $\begin{array}{r}8,090,000 \\
3,786,000 \\
3,705,000 \\
8,736,000 \\
13,400,000 \\
14,510,000 \\
88,380,000 \\
16,250,000 \\
17,000,000 \\
15,670,000 \\
16,723,000 \\
22,840,000 \\
51,800,000\end{array}$ & $\begin{array}{r}243,6010 \\
235,000 \\
248,500 \\
557,000 \\
867,000 \\
837,000 \\
800,000 \\
697,000 \\
650,000 \\
720,000 \\
672,000 \\
812,000 \\
1,400,000\end{array}$ \\
\hline
\end{tabular}

Tables Nos. XV and XVI taken from Ontario Bulletin No. 117.

" Rogers, L. A. U. S. Bulletin No. 73. Page 28.

** Dean and Harrison, Ontario Bulletin, No. 117. Pages 11.12. 
Results of Continuous Pasteurization of Milk at

$$
160-165^{\circ} \text { F. }(71-74 \text { c.) }
$$

TABLE XVI.

T'uenty Tests, Percentage of Bacteria Killed, 99.95.

\begin{tabular}{|c|c|c|c|c|c|}
\hline \multirow[b]{2}{*}{ Date } & \multirow[b]{2}{*}{$\begin{array}{l}\text { Pasteuriz- } \\
\text { ing tem- } \\
\text { perature }\end{array}$} & \multirow{2}{*}{$\begin{array}{c}\text { Tempera- } \\
\text { ture of } \\
\text { milk before } \\
\text { pasteurizing }\end{array}$} & \multirow[b]{2}{*}{ Acidity } & \multirow{2}{*}{\begin{tabular}{|c|} 
Unpasteurized \\
Average \\
germs \\
per c. c.
\end{tabular}} & \multirow{2}{*}{$\begin{array}{c}\text { Pasteurized } \\
\text { Averuge } \\
\text { germs } \\
\text { per c. c. }\end{array}$} \\
\hline & & & & & \\
\hline $\begin{array}{cr}\text { Mar, } & 29 \\
\text { April } & 1 \\
\text { “ } & 3 \\
“ & 6 \\
“ & 10 \\
\text { “ } & 17 \\
\text { “ } & 19 \\
\text { May } & 29 \\
\text { “" } & 15\end{array}$ & $\begin{array}{l}160 \\
160 \\
164 \\
160 \\
160 \\
160 \\
160 \\
160 \\
165 \\
160 \\
165\end{array}$ & $\begin{array}{l}53 \\
46 \\
52 \\
54 \\
53 \\
54 \\
56 \\
46 \\
60 \\
58 \\
60\end{array}$ & $\begin{array}{l}.15 \\
.16 \\
.15 \\
.16 \\
.15 \\
.15 \\
.19 \\
.17 \\
.21 \\
.15 \\
.19\end{array}$ & $\begin{array}{r}507,600 \\
1,402,100 \\
288,000 \\
2,784,000 \\
7,040,000 \\
8,090,000 \\
9,090,000 \\
1,820,000 \\
25,100,000 \\
8,736,000 \\
4,050,000\end{array}$ & $\begin{array}{r}510 \\
8,950 \\
510 \\
410 \\
9,025 \\
650 \\
2,300 \\
93,800 \\
11,420 \\
23,250 \\
15,700\end{array}$ \\
\hline
\end{tabular}

\section{The growth of bacteria in milk.}

The increase of the bacteria in milk depends mostly upon the temperature at which it is kept during the first few hours after it is drawn. According to Grotenfelt's "Modern Dairy Practice" we find that Cropf and Eiserich in Munich found 60,000 to 100,000 bacteria per cubic centimeter in milk shortly after it had been drawn. This sample was kept in 8 cellar at a temperature of 12.5 degrees C. (56.5 degrees F.). After two hours the bacterial content was four times as great as at first; after three hours it was eight times as great; after five hours it was twenty-six times as great, and after six hours it was 1,803 times at great. Another portion of this milk was held at 35 degrees (. $\left(95^{\circ}\right.$ F.) in an ineubator and the bacteria originally present multiplied twenty-three times in two hours; 215 times in four hours; 803 times in five hours and 3,800 times in six hours. The development of the bacteria in the milk kept in ice during the same period of time was so slight as 
to be almost imperceptible. This is a striking illus1 ration of the developinent of germs under different temperatures. When we consider that one germ often reproduces itself every twenty minutes it is not surprising that milk or cram ran become bad so quickly.

239. Care and cleanliness. It is obvious that the laclerial content of the milk is greatly affected by various methods of handling and that there is a "lose relationship butween the bacterial content of the milk and the different fermentations which manifest themselves from time to time. In our efforts to insure a good-kepping article we are impressed with the noed of having the utmost eare exereised in the handling of milk before it is received at the factory or central plant. But unfortunatcly we sometimes fail to recognize or to remember that aftor the milk arrives at the central plant it still needs to be carefully and intelligently handles. Not only should milk be heated to a high enough temperature to destroy undesirable germs, but the temperature should be uniform, and must bo maintained for a sufficient length of tima to insure the destruction of those germs. It must also bu borne in mind that the crmperature must not be so high as to impart a permanent cooked flavor to the produet.

It is to be deplorod that clamliness, that all-jmportant factor in the handling of milk, is so often neglected at the furtory or milk depot. When this is the case all th" "ar" which has previously been bestow'd upon the milk is practically undone. Otto F. Hunzikur, of the Dairy Division of Cormell I'niversity, in a re'(n)t bulletin on "The Ifandling and 
Care of Milk," says: "The greater attention paid to scrupulous cleanliness in handling milk at all stages, the shorter time that elapses between the drawing, straining, and cooling of the milk, and the lower the temperature to which it is cooled, the greater will be its freedom from miero-organisms; the longer it will retain its normal condition; the more profitable its production will be and the more wholesome will it be for old and young." In these few words we find the secret of success in handling milk and cream.

240. Clarification and separation. When a large quantity of milk is handled at one plant for city supply and shipped or hauled to the plant for a considerable distance, it is of the utmost importance if the milk is not very clean, that it be clarified. By clarification I mean that the milk is to be separated and milk and cream run together again before it is used. This should be done whether the milk it to be pasteurized or not. After clarification it should be immediately cooled to as low a temperature as possible unless it is to be pasteurized at once. It has been ascertained that in the process of separation a large number of tubercle bacilli and lactic germs are deposited in the separator slime. Grotenfelt in his "Modern Dairy Practice" says: "I have verified in numerous trials that a large number of the bacteria present in milk were removed from the cream and skim milk by the centrifugal force and went into the separator slime."

241. The grading of milk. In order that a uniform grade of milk be placed upon the market it is necessary to select by an acid test all milk that may indi- 
cate an excess of .2 per cent acidity. This can very easily be accomplished by using the "Rapid Method" (par. 48), devised by Prof. E. H. Farrington, who is at the head of the University of Wisconsin Dairy School. Anyone who is at all dextrous can very rapidly select or grade milk as received at the milk depot. The rapid method is simple, accurate and inexpensive, and is used with great success at the Wisconsin Dairy School.

Because the sweeter milk is selected for the market it is possible that when a large percentage of the milk shows more than .2 per cent acidity and is rejected, that the test of the milk sold may show a rather low fat content. The reason of this is that evening milk is usually richer in fat than morning milk and it is usually the latter which shows more than .2 per cent acidity. According to Richmond (Richmond*) the composition of milk varies greatly in fat content. He says: "The average fat content of morning milk was 3.52 per cent and of evening milk 3.96 per cent in 15,910 samples."

\section{Variations in the test of individual cows and} herds.

There is a difference in the average test of a herd from year to year as well as in the test of individual cows. The test of individual cows may vary considerably from day to day as well as the total production of fat per day. In order to make this variation more clear, the following table is given, which shows the age of cows, the average per cent of fat in milk and the range of variation in milk from individual cows.

* Richmond, H. D. Analyst, page 30, 1905 . No. 355, paragraphs 325-329. 
243. Table XVII, showing the variation in the test of milk from individual cows. (Woll and Harris.*)

\section{'IABLE XVII.}

Showing the Variation in the Test of Mill From Individual Cows: (Woll and Harris*)

\begin{tabular}{|c|c|c|c|c|}
\hline \multirow{2}{*}{$\begin{array}{l}\text { Age of } \\
\text { cow }\end{array}$} & \multirow{2}{*}{$\begin{array}{l}\text { Days } \\
\text { in } \\
\text { milk }\end{array}$} & \multicolumn{2}{|c|}{ Per cent fat } & \multirow{2}{*}{$\frac{\text { Fat per day }}{\text { Range }}$} \\
\hline & & Average & Range & \\
\hline I. M. D. & & & & \\
\hline $8-10-19$ & 37 & 3.27 & $2.3-4.2$ & $2.847-3.426$ \\
\hline $9-1-20$ & 6 & 5.57 & $3.65-8.48$ & $3.211-3.921$ \\
\hline $7-10-22$ & 49 & 3.71 & $2.65-4.8$ & $2.677-3.199$ \\
\hline $8-1-19$ & 15 & 3.92 & $3.18-4.98$ & $2.495-2.864$ \\
\hline $8-4-10$ & 24 & 3.40 & $2.8-4.08$ & $2.422-3.087$ \\
\hline $6-9-12$ & 12 & 3.49 & $2.95-3.88$ & $2.501-3.069$ \\
\hline $6-9-12$ & 20 & 3.33 & $2.8-4.0$ & $2.933-3.320$ \\
\hline $7-1-25$ & 11 & 4.29 & $3.35-5.0$ & $2.422-2.861$ \\
\hline $5-11-15$ & 4 & 5.02 & $3.45-6.0$ & $3.479-4.045$ \\
\hline $5-11-6$ & 33 & 3.51 & $2.58-4.2$ & $2.829-3.500$ \\
\hline $5-7-18$ & 26 & 3.96 & $3.18-4.53$ & $2.536-2.794$ \\
\hline $5-10-19$ & 19 & 3.69 & $2.9-5.5$ & $3.020-3.347$ \\
\hline $5-0-29$ & 6 & 5.13 & $3.9-6.45$ & $2.969-3.447$ \\
\hline $5-0--15$ & 19 & 3.91 & $3.1-5.2$ & $2.891-3.172$ \\
\hline $6-10-9$ & 20 & 3.94 & $2.3-6.45$ & $2.422-4.045$ \\
\hline $6-11-28$ & 20 & 3.58 & $1.6-8.48$ & $1.464-4.045$ \\
\hline $4-4-8$ & 69 & 3.50 & $2.8-4.85$ & $2.034-2.691$ \\
\hline $4-0-4$ & 13 & 3.83 & $3.13-4.53$ & $2.271-2.392$ \\
\hline $4-2-28$ & 17 & 3.80 & $2.7-4.55$ & $2.574-3.034$ \\
\hline $4-0-29$ & 4 & 3.38 & $2.7--4.4$ & $2.204-2.535$ \\
\hline $4-2-2$ & 26 & 3.63 & $2.7-4.85$ & $2.094-3.034$ \\
\hline $4-3-16$ & 24 & 3.52 & $1.5-6.15$ & $1.225-3.034$ \\
\hline $3-5-1$ & 29 & 3.37 & $2.4-4.83$ & $2.000-2.865$ \\
\hline $3-7-4$ & 11 & 3.92 & $3.0-4.65$ & $2.538-2.740$ \\
\hline $3-7-14$ & 53 & 3.53 & $2.65-4.23$ & $1.979-2.261$ \\
\hline $3-11--14$ & 18 & 3.53 & $2.6-4.53$ & $2.579-3.137$ \\
\hline $3-11-8$ & 33 & 3.48 & $2.8-4.3$ & $1.983-2.331$ \\
\hline $3-4-23$ & 8 & 3.64 & $3.33-3.95$ & $2.140-2.288$ \\
\hline $3-3-18$ & 7 & 3.72 & $3.3-4.2$ & $2.059-2.274$ \\
\hline $3-1-28$ & 17 & 3.56 & $2.9-4.55$ & $2.318-2.769$ \\
\hline $3-2-28$ & 19 & 3.64 & $2.6-4.43$ & $1.946-2.201$ \\
\hline $3-4-28$ & 4 & 3.80 & $2.6-5.58$ & $2.032-2.496$ \\
\hline $3-2-21$ & 15 & 3.44 & $2.8-4.3$ & $1.896-2.121$ \\
\hline $3-0-19$ & 6 & 4.02 & $3.0-5.78$ & $2.057-2.188$ \\
\hline
\end{tabular}

* Woll and Harris, Wisconșin Station. Bulletin No. 172. 1909. 
244. Variation in the per cent of fat in cow's milk during the entire period of lactation.

\section{TABLE XVIII.*}

Taration in the P're C'ut of Fat in Cous' Milk During the lintire Pcriod of Lactation.

\begin{tabular}{|c|c|c|c|c|c|}
\hline \multirow[t]{2}{*}{$\begin{array}{l}\text { No. of } \\
\text { Cow }\end{array}$} & \multicolumn{2}{|c|}{$\begin{array}{l}\text { Range in } \\
\text { Per cent of fat }\end{array}$} & \multirow[t]{2}{*}{$\begin{array}{c}\text { No. of } \\
\text { Cow }\end{array}$} & \multicolumn{2}{|c|}{$\begin{array}{l}\text { Range in } \\
\text { Per cent of lat }\end{array}$} \\
\hline & Lowest & II ighest & & Lowest & Hîghest \\
\hline 1 & $2 .(i 21 \%$ & $4.698 \%$ & 10 & $2.464 \%$ & $6.00 \%$ \\
\hline 2 & $2.160 \%$ & $3.404 \%$ & 11 & $2.741 \%$ & 4.649\% \\
\hline 3 & $\ldots \ldots$ & & 12 & $2.509 \%$ & $5.505 \%$ \\
\hline 4 & $2.163 \%$ & $3.965 \%$ & 13 & $2.645 \%$ & $4.724 \%$ \\
\hline 5 & $2.543 \%$ & $3.900 \%$ & 14 & $2.097 \%$ & $4.173 \%$ \\
\hline 6 & $2.096 \%$ & $3.446 \%$ & 15 & $2.437 \%$ & $4.234 \%$ \\
\hline 7 & $2.257 \%$ & $3.837 \%$ & 16 & $2.326 \%$ & $4.637 \%$ \\
\hline 8 & $2.690 \%$ & $4.117 \%$ & 17 & $\ldots$ & $\ldots \ldots$ \\
\hline !) & $2.566 \%$ & $4.709 \%$ & 18 & $2.537 \%$ & $4.390 \%$ \\
\hline
\end{tabular}

245. A standard temperature for pasteurization.

The main qucstion in pasteurization is: What is the best temperature at which to pasteurize milk or cream? Another important matier in connection with this subjeet is the length of time the milk or cream should be exposed to a given temperature in order not to injure its quality, and yet destroy the tuberele bacilli. When the tubercle bacilli are destroyed we feel sure that all other harmful germs are also destroyed. This can be accomplished in either of two ways: First, by short exposure to a temperature of $180^{\circ} \mathrm{F}$. to $190^{\circ} \mathrm{F}$. Second, by holding the milk or cram at a temperature of $140^{\circ} \mathrm{F}$. to $160^{\circ} \mathrm{F}$. for some length of time. I believe we are safe in using the following temperature and time:

"Table XVIII was translated by Leonard Pearson, (C, O. Jensen Milk Hygiene.) 
Temperature. Hold for. Temperature. Hold for. $-140^{\circ} \mathrm{F} \ldots . .30 \mathrm{~min} . \quad 160^{\circ} \mathrm{F} \ldots . .10 \mathrm{~min}$. $145^{\circ} \mathrm{F} \ldots \ldots .25 \mathrm{~min} . \quad 170^{\circ} \mathrm{F} \ldots \ldots .5 \mathrm{~min}$. $150^{\circ} \mathrm{F} \ldots \ldots 20 \mathrm{~min} . \quad 180^{\circ} \mathrm{F} \ldots . .2 \mathrm{~min}$. $155^{\circ} \mathrm{F} \ldots \ldots .15$ min. $190^{\circ} \mathrm{F} \ldots \ldots 1 \mathrm{~min}$.

'The temperatures employed under commercial conditions must necessarily be a little higher than the temperatures used under laboratory conditions and expert supervision. If we were to use laboratory temperature under commereial conditions the results might not always be satisfactory.

246. Jensen and Platnner come to the conclusion that in order to preserve the properties of raw milk, which is especially desirable in infant feeding, the "heating should not be continued for several hours at $60^{\circ} \mathrm{C}$. or $140^{\circ} \mathrm{F}$. nor exceed for a single instant $70^{\circ} \mathrm{C}$. or $158^{\circ} \mathrm{F}$. The temperature should not exceed that necessary for destroying pathogenic bacteria, more particularly the tubercle bacillus for which heating for 20 minutes at $60^{\circ} \mathrm{C}$. or $140^{\circ} \mathrm{F}$. is sufficient," as found by Smith; and 5 minutes at $65^{\circ} \mathrm{C}$. or $149^{\circ} \mathrm{F}$. as found by Bang and Strebolt. These authors (Jensen and Platnner*) also recommend the home pasteurization of milk for infant feeding. It would seem, however, that since the average housewife is not sufficiently educated along this line that it would be safer for her to buy properly pasteurized milk from some responsible city milk dealer. I believe that the pasteurization of milk can be more efficiently performed by a high class city milk plant than by the average housewife.

- Jensen and Platnner. American Agricultural Suisse, 6, 1905. No. 6, pages 205-228, etc. 


\section{Intermittent system of pasteurization.}

When we speak of the intermittent system of pasteurizing, we mean that the milk or eream to be pasteurized is all placed in a machine or tank and all heated at one time to the desired temperature and held at this temperature for the required length of time. When the milk has been hold heated for a sufficient length of time it is cooled, and then bottled direct from the pasteurizer by a sanitary bottling apparatus.

248. The disadvantage of this system is that where a large quantity of milk or cream is to be handled, the expense of handling it is greater than when the continuous or semi-continuous pasteurizer is used. The main cause of additional expense in using the intermittent system of pasteurizing is that it requires a greater length of time to pasteurize a large quantity of milk as well as additional machinery, where great quantities are handled. One great advantage that this system has over all others is that perfect pasteurization is more casily accomplished. The cream line, which the American people like to see on milk, can more easily be retained when the intermittent system of pasteurizing is used, because the milk need not be heated above $150^{\circ} \mathrm{F}$. in order to destroy the tubercle bacillus.

In case milk is separated and the cream run into a discontinuous pasteurizing apparatus, it should be heated to about $130^{\circ} \mathrm{F}$. and kept at this temperature until all the cream is in the machine. It should then all be heated to the desired temperature for pasteur- 
jzing. This is necessary because cream fresh from the separator sours very quickly unless it is cooled to about $50^{\circ} \mathrm{F}$. or heated to about $135^{\circ} \mathrm{F}$. During the heating of the cream as well as during the time the milk or cream is held hot, it should be kept in motion except for very short periods of time. We know that the efficiency of work done depends primarily upon the dgree, duration and uniformity of heat applied. By the use of the intermittent system of pasteurizing the milk or cream may acquire a slightly cooked flavor even though it is heated to only $140^{\circ} \mathrm{F}$., but this will disappear within twentyfour hours, especially if the milk or cream is cooled rapidly.

249. Continuous pasteurizers. These pasteurizers are very generally used in creameries for the pasteurization of cream for butter making on account of the relatively high acid in the cream; and up to the present time this type of pasteurizer is also used to a great extent for the handling of milk for city supply.

The advantage of this type of machine is that a large amount of milk or cream aan be cheaply handled. The cooling can be accomplished quickly, thus retarding the development of any bacteria which may have escaped destruction. Great care must be exercised in applying proper temperatures and in guarding against running the machine above its tested eapacity.

250. Semi-Continuous pasteurizers. It is only recently that holding devices as an adjunct to continuous pasteurizers have been put upon the market. 
This holding apparatus serves a very necessary purpose in increasing the efficiency of the machine. The milk or cream can be pasteurized at lower temperatures and the same results obtained as with high temperatures.

251. Cleaning pasteurizers. After pasteurizing, the machine should be cooled by running water through it and when sufficiently cooled, a solution made with some good cleaning powder and water should be run into the heating chamber to dissolve and loosen the milk which may be cooked onto it. This should be allowed to stand in the machine for some time, and the machine should then be scrubbed with a stiff brush. Be very careful about using sulphuric acid on the pasteurizer, because if line solution is too strong it will corrode the tin and cause it to wear off in a short time. Strong lye will also take off the tin and it should be very sparingly used.

Milk or cream will not easily burn onto the pasteurizer if the heating chamber is first filled, and then slowly heated to the desired temperature, or if it is heated very slowly while the chamber is being filled. Always guard against running the pastrurizer empty, with full steam pressure on.

\section{Prejudice against pasteurized milk and cream.}

Were it not for the fact that the average consumer wants to see a well defined cream line on bottled milk, pasteurization would be more generally praceticed. This opposition has led to the construction of machinery which will handle milk or cream with the greatest effieiney at the lowest temperature. The slightly cooked Havor which sore pasteurized milk 
has, is not relished by consumers and more or less objection has been raised to it. As soon as the consumer learns that the keeping quality of the milk and cream is increased by pasteurization, it will become general.

\section{Sources of bacteria in milk.}

\section{TABLE XX.}

Element of Contamination................ Bateria

1. Infection $\left\{\begin{array}{l}\text { Fresh Milk .............. } 6,600 \text { yer c.c. } \\ \text { After passing through } 6 \text { i vessels. } 97,000 \text { per c.c. }\end{array}\right.$

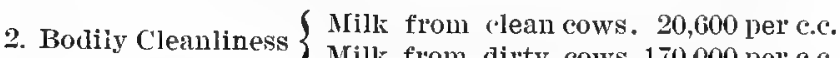

3. Litter $\left\{\begin{array}{l}\text { Peat } \ldots \ldots \ldots \ldots \ldots \ldots \ldots \ldots \\ \text { Good straw . . . . . . . . . . . } 7,500,000 \text { per gramme }\end{array}\right.$ Bad straw . . . . . . 10,000,000 per gramme

4. Influence of litter in num- $\{$ With pent litter . 3,500 per c.c. ber of bacteria in milk. . \{ With straw litter 7,330 per c.c.

5. Food. Dust of $\{$ Oil alke ...... 457,500 per gramme in the manger $\{$ Bran ......... 1,361,900 per gramme

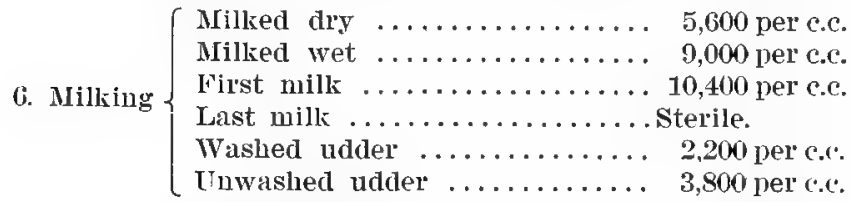

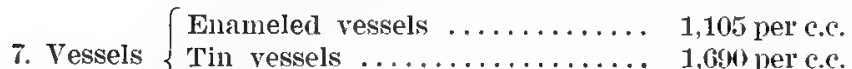
Wooden vessels ...........279,000 per c.c.

8. Cleansing Vessels $\left\{\begin{array}{l}\text { Sterilized pail } \ldots \ldots \ldots \\ \text { Simply rinsed } \ldots \ldots\end{array}\right.$

Table XX, C. O. Jensen, Milk Hygiene.

254. Epidemics caused by raw millk. If dairymen and milk dealers really understood what cleanliness in the production of milk means, and would employ 
proper methods of pasteurization, epidemics which are direstly trawable to infected milk might be avertad. In Europe epidemies which were traced to the consumption of infected milk occurred in Macclesfielk, Wimbledon, Yorktown, Camberly, Canterbury, Bristol, Clifton, London, Barrowford, Fallowfirld and Oxford. In America epidemies of this kind occurred at Iowa State Colleg ${ }^{\prime}$, Norwood, Salem, Adams, Elkton, Providence, Buffalo, Sommerville, Springfield, Port Jarvis, ete.

We cannot cite an instance where pasteurization has created any trouble of this nature, and nothing "in be shown to prove that pasteurization should be dispransed with. From records now available we find there is great discomfort to people, as well as disease and death resulting from the consumption of raw milk and its products. A great source of infection of milk comes from the handling of it by persons affected with contagious diseases. 


\section{CHAPTER XIII.}

\section{DETERMINATION OF MOISTURE IN BUTTER}

It (Wisconsin High Pressure Oven) has proved to be well adapted to the purpose for which it is intended, and the results obtained by its use are accurate.

E. H. FARRINGTON. 


\section{INDEX TO CHAPTER XIII.}

Parr. No.

Page.

255. Detorminations of moisture in buttel ....... 201

256. Necessary apparatus ................... 201

257. Muking the test ................... 202

(a) I'reparing simples $\ldots \ldots \ldots \ldots \ldots \ldots \ldots \ldots 202$

(b) Making a churn test............... 202

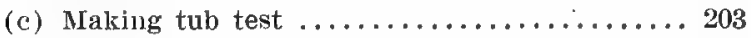

(d) Making print test . . . . . . . . . . . 203

258. Methods in some creameries not up to standard. . 203 259. Ilow to treat cups and pans............. 204 260. Testing leaky or slushy butter........... 205 261. Testing butter by Babcock test........... 206 262. Number of grams of butter necessary ........ 210 263. T'able XXI., comparing two methods of testing butter for moisture ............... 212 


\section{CHAPTER XIII.}

\section{Determination of Moisture in Butter.}

255. Some creamery operators have increased the per cent of moisture in butter to such an extent that the production of good bodied butter was impossible; and since they sold the excess of water at butter prices it became necessary for the federal government to put a stop to this practice by limiting the per cent of moisture to 15.9 per cent.

It is due to this regulation that devices for testing butter for moisture have come into use, and within the last few years several different moisture tests have been placed upon the market. Information regarding these tests, with directions for their use and suggestions regarding the taking of samples, are furnished free upon application to creamery supply houses mentioned in the chapter on information in the back of the book.

256. Necessary apparatus for determining moisture in butter.

Apparatus necessary for testing moisture in butter is as follows:

1. A correct and sensitive scale.

2. A butter trier, spatula or knife.

3. Cups or pans according to the kind of moisture testing apparatus used.

4. A moisture testing apparatus. Farrington High Pressure, Ames or Gray's.

5. A cup or wide mouthed jar for preparing composite samples. 
All that is needed in addition to the above is a person who is very careful in handling all processes. connected with the determining of moisture. The results should come within $1 / 4$ to $11 / 4$. per cent of the actual per cent of moisture in the butter.

\section{Making the moisture test.}

(a). Preparing samples. When a churn test is desired, take a butter trier and take a small sample from each trierful taken from four or five different places in the column of butter in the churn. Be sure to take samples from both ends and the middle of the column. When a knife or spatula is used, remove the surface of the butter, take a few grams, place the sample in a cup or glass and add to it other small samples taken from four or five places in the butter column. This constitutes the composite sample, from which ten or fifteen grams should be taken, weighed and tested according to the directions for whatever moisture test is being used. Before taking a sample for testing from the composite sample, place the cup containing the composite sample in water of a temperature of $98^{\circ}$ to $100^{\circ} \mathrm{F}$. and stir continually until the sample has reached a soft, smooth consistency. When this stage is reached remove the cup at once from the warm water, balance your scales carefully and weigh out ten or fifteen grams as desired.

(b) When making a churn test and the sample is to be taken from the tubs or boxes just packed, take a knife or spatula and take a small piece of butter from each tub or box and proceed as indicated for the handling of the composite churn sample. 
(c) When making a tub test when butter is three or more days old and is hard, use a trier of a length sufficient to pass through the entire length of the tub or package. Pass the trier into the butter and take a few grams of butter from four different places on the trier and place in a cup or screw top glass jar. If there are a number of tubs from the same churuing take samples from another tub or two and procecd as before directed. The results should creck up within $1 / 4$ to $1 \frac{1}{4}$ per cent of the actual moisture in the butter.

(d) When making a print butter test it is well to take a trier and take a full length plug from a print. From this take a small piece and repeat this with several prints, or cut a print in two and take a thin slice across it at the cut. Repeat this with several prints and handle these samples as previously indicated.

258. Methods used in creameries for the determination of moisture in butter are not up to the desired standard. In my travels among creameries as well as through information gained by correspondence regarding methods used in making moisture determinations, I found that methods employed in taking samples for making moisture determinations as well as the handling of the different processes connected with the testing were not what they should be. As a rule the fault was not in not knowing how to take a fair averaga sample, but rather in the lack of care and attention to the detail part of the work. For instance:

1. Not balancing the scales properly. 
2. Not accurately weighing the number of grams of butter used for making the test; that is, having it a trifle over or under weight.

3. Not drying the cups or pans in which the butter was weighed.

4. Not accurately weighing the sample after the moisture is all cxpelled.

5. Wrighing the sample whin hot from the oven or flame, or letting the sample stand too long cold before weighing.

6. Not taking into consideration the fact that when butter spatters over the beaker when direct flame is used, that the results are greatly affected.

7. Using poor beakers, with a rough surface or a handle soldered onto the side, allowing moisture and dirt to adhere to it.

8. Not carefully solidifying liquefied samples of butter before weighing out samples for testing.

9. Using old, heavy operating crcam scales instead of the Torsion Balance; No. 4,000 or No. 1,600 or any high grade druggist scale.

10. Forgetting that when a littlo bit of butter is taken from the surface of the butter column in the churn, the result is usually too high, and hardly ever represents the true per cent of moisture.

259. How to prepare the cups and pans used in testing for moisture.

All cups, pans or utensils into which samples are to be put for testing should be heated before the samples are put into them. This is done to expel any moisture which might adhere to these vessels. If it is not done, and a little moisture adheres to cup 
or pan and is weighed with the sample of butter, the result will show a higher per cent of moisture than the butter actually contains. I have found that by neglecting to dry the vessels into which the samples are weighed, and by not having the plates on the scale, on which the pans were placed, perfectly clean and $d r^{2} y$, a difference of 2.5 per cent in the actual per cent of moisture was the result. In one creamery a rickety old scale was used and the result was 8 per cent too low. That is, the resulf obtained when the sample was not correctly weighed was 12 per cent moisture. When the sample was weighed on an accurate scale, the actual moisture content was found to be 20 per cent. When the scale is clean, accurate and well kalanced, the cups or pans heated before the butter is weighed into them, the sample accurately taken and correctly weighed, the moisture all expelled, the sample again accurately weighed and the mathematical calculations properly performed, the result will be very close to the actual per cent of moisture in the butter.

260. Testing leaky or slushy butter for moisture.

It is very hard to test this kind of butter satisfactorily on account of the presence of much loose water as well as considerable water being held in large pockets throughout the butter. When sampling this kind of butter it is well to take nore samples from different parts of the tub or churr than are taken when well made butter is tested. When this kind of butter is hard,_a great deal of water may drip off of the trier and the sample may show results much too low in the per cent of moisture. In such a case 
it is saf:r to make two tests of the same lot of buttire, as the result of two trists is a truer indication of the actual moisture present.

261. Testing butter for butter fat by the Babcock test, and from results, computing the approximate moisture content. Experience has faught that moisture cannot be accurately computesl by knowing the approximatr per cent of fat in butter. The per cent of salt in butter varies too much for this to be a reliable trist. It would be impossible to make an aceurate guess as to the per "'nt of salt in butter, and to test for salt as well as for butter fat would take more time than it would take to make a moistur. trast. Even the use of the Babcock test for determining the per cent of butter fat in butter is not to bo recommended due 10 errors arising from various sources. This is fully explained in the following by Prof. E. II. Farrington, Hoard's Dairyman, July 1, 1910:

"Among the various factors which make these results uncertain are the following:

1. Taking a fair sample of butter.

2. Accurate wrighing of the buttrer into the test bottle.

3. The high per 'ent of fat in butter which makes prors in reading the length of the fat column due to "hanges in temperature much grester than in milk.

4. The difficulties in getting the fat fres from water when it is measurerl in the nork of the test bottliss.

The effect of thrse various arrol's of analysis is five times as great on the fat as it is on the water deter- 
mination in butter when butter contains 80 per cent fat and 16 per cent water, and the effect of these errors is twenty times as great for butter testing as it is for milk testing when the latt $\sim \mathrm{r}$ contains 4.0 per cent fat.

The errors which may occur in weighing the sample of butter for testing is multiplied by the ratio between the weight taken and 100 . If an error of one-tenth gram is made in weighing 10 grams of butter, this one-tenth gram is one-tenth per cent of 100 , but it is 1 per cent of 10 grams; and 80 per cent of this 1 per cent falls on the butter fat, while only 5 per cent of it would fall on a milk testing 4 per cent fat.

The actual effect which an error of one-tenth gram in weighing out the butter will have on the final results may be seen by the following illustration: If instead of ten grams only 9.9 grams of butter are weighed into a test bottle, after which the test is completed and the reading of the fat in the neck of the test bottle is found to be 45 . This reading multiplied by 18 gives 810 , which divided by 10 grams of butter gives 81 per cent fat in the sample test. If, however, an error of one-tenth gram is made in weighing, and the product of $45 \times 18$ or 810 is divided by 9.9 grams, then the result is 81.8 per cent fat.

The variation of one-tenth gram in weighing the sample of butter into the test bottle has made an error of .8 per cent fat in the fingl result.

If this same error of one-tenth gram is made in weighing six, instead of ten grams of butter into a test bottlc, and the test of the butter is made in 
cream test bottles reading to 30 or 40 per cent, the effect of this small error is much greater. Suppose the reading of fat from the six grams of butter is 28; this multiplied by 18 gives 504 , which divided by six (the weight of butter taken) gives 84 as the per cent of fat in the sample tested. If, however, the reading 28 multiplied by 18 or 504 is divided by 5.9 instead of six, then the result is 85.4 .

This shows a difference of 1.4 per cent fat between the result obtained when the weight of butter is taken as six grams and when it is 5.9 grams.

If this same error of one-tenth gram is made in weighing the butter for a water determination, the effect of the error on the final result will be much less as is seen by the following figures: If ten grams of butter are weighed for a water determination, and the loss of weight by drying is 1.6 grams, then this loss is 16 per cent of the ten grams of butter weighed out. If an error of one-tenth gram was made in weighing the butter then the loss, or $\mathbf{1 . 6}$ grams divided by 9.9 grams instead of ten grams of butter gives a percentage of 16.1 per cent water in the sample tested. In this case there is a difference in the final result of only one-fortieth per cent when an error of one-tenth gram was made in weighing the butter.

Butter makers in ereameries do not often make weighings closer than 1-10 grams on the scales they use and many of these scal's are not sufficiently sensitive to weigh as fine as 1-10 gram. They will, therefor', have difficulty in getting duplicate tests of the same sample of butter to agree much closer 
than 1.0 per cent fat, simply because of the effect of this one source of error which is introduced when weighing the butter for testing.

Another point in testing butter for fat by the Babcock test, that will have a great effect on the final results, is the temperature of the fat column when it is measurcd. The extent to which the fat column will change with the increase or decrease in temperature is shown by the following figures:

The expansion of fat by a change of 40 degrees in temperature amounts to .07 per cent. fat in milk testing 5 per cent fat; that is, if a milk testing 5 per cent fat is read at $110^{\circ} \mathrm{F}$. the reading will be 5.07 per cent fat when the temperature is raised to $140^{\circ} \mathrm{F}$.

This same effect of expansion on the test of butter containing 80 per cent fat will be 16 times more, or $.07 \times 16$ equals 1.12 per cent fat, which will be the difference in the reading of the butter fat test at $110^{\circ}$ and $140^{\circ} \mathrm{F}$. Or, if the fat test of a sample of butter when read at 110 is 80 per cent fat, the same sample read at $140^{\circ} \mathrm{F}$. will be 81.12 per cent fat.

All the other exrors of manipulation in testing butter by the Babcock test, such as determining the point of reading the top and bottom of the fat column, loss of moisture and of the butter when it is being weighed into the test bottles, and other mechanical losses, are at least five times as great for a fat as for a water determination in butter, and 20 times as great for butter as for milk testing 4 per cent fat. 
The errors all come on the amount of the substance tested and 80 per cent of this error falls on the fat, while only 16 per cent of it falls on the water in butter and 4.0 per cent of the error would fall on the fat in milk testing 4.0 per cent fat.

After understanding the full effect of all the errors of analyses, as well as the difficulty of weighing butter into test bottles, the necessity of using extreme care in every manipulation and in keeping the scales and glassware in a most sensitive and accurate condition, one must not expect to use the Babcock test for determining fat in butter with the same degree of accuracy as it is used in milk and cream testing. Duplicate results on the same sample of butter may not agree within 1 per cent of each other and the results obtained may easily be 2 per cent from the actual fat contained in the sample tests. All these variations and inaccuracies being due to the errors of analyses and the fact that the fat is such a large percentage of the butter.

When fairly satisfactory results are obtained in testing butter by the Babcock test it is probable that the errors of one class have compensated for, or balanced the errors of another class in the opposite direction, but at the same time it is possible that all the errors may be in the same direction and thus increase the inaccuracies of the results."

262. Number of grams of butter to use for making moisture determinations. By consulting the Dairy Arithmetic it will be seen that the smaller the basis upon which moisture determinations are based the greater is the per cent of error, caused by an error. 
It is not wise to weigh less than five grams of butter to be used for testing for moisture, and it is much more safe to use ten or fifteen grams of butter for this purpose. A slight error does not affect the result so much when fifteen grams are used as when only five grams are used, supposing the same error is made in each case. To illustrate:

I. A lot of butter is weighed, and is supposed to weigh 850 lbs., but by some error in handling it weighs only $848 \mathrm{lbs}$. The loss in pounds here is 2 or in per cent is $2 \div 850=.002353 \times 100=.2353$ - or $.23+$ per cent.

II. A lot of butter is weighed as 48 lbs. when the actual weight is 50 lbs. Here an error of 2 lbs. is made. Expressing the loss in per cent it will be $2 \div 50 \times 100=4$. per cent.

A loss of 2 lbs. on $850 \mathrm{lbs}$. is .23+ per cent or .23 of one pound on every hundred pounds.

A loss of 2 lbs. on 50 lbs. is 4 . per cent, or 4 . lbs. on every hundred pounds. By losing 2 pounds on every $50 \mathrm{lbs}$. the loss is 17 . + times as great as when the loss is $2 \mathrm{lbs}$. on every $850 \mathrm{lbs}$. This can be found by dividing the loss in per cent: $4 . \div 2353=17 \times$ $100=17$. or $850 \div 50=17$.

This shows that when an error is made in weighing out only 2 grams the result obtained is increased enormously, while the same error made when 10 or 15 grams are weighed out would be very small, and in many cases not noticeable in the results.

The smaller the sample used for testing the greater must be the care taken in its preparation and handling, as well as in calculating the result. 
The chances for error as indicated above are considered from the standpoint of practical creamery operations and not under expert laberatory conditions.

263. Table No. XXI shows how closely the results obtained with the Wisconsin High Pressure Oven agree with official methods. *

\section{TABLE XXI.}

Per ('r'nt Water in Butter Samples Fround by Using Both the High Pressutre Oven Ifethod and the Official Chemists' Method.

\begin{tabular}{|c|c|c|}
\hline & \multicolumn{2}{|c|}{ Per cent water ia butter } \\
\hline & $\begin{array}{l}\text { Official chem- } \\
\text { ists' method }\end{array}$ & $\begin{array}{l}\text { High-pressure } \\
\text { oven-method }\end{array}$ \\
\hline Sample No. $1 \ldots \ldots \ldots \ldots$ & $\begin{array}{l}13.05 \\
13.20\end{array}$ & $\begin{array}{l}13.1 \\
13.1\end{array}$ \\
\hline Sample No. $2 \ldots \ldots \ldots \ldots$ & $\begin{array}{l}18.71 \\
18.92\end{array}$ & $\begin{array}{l}19.0 \\
19.1\end{array}$ \\
\hline Sample No. $3 \ldots \ldots \ldots \ldots$ & $\begin{array}{l}20.89 \\
20.90\end{array}$ & $\begin{array}{l}21.0 \\
21.0\end{array}$ \\
\hline Sample No. $4 \ldots \ldots \ldots \ldots$. & $\begin{array}{l}12.37 \\
12.25\end{array}$ & $\begin{array}{l}12.5 \\
12.45\end{array}$ \\
\hline Sample No. $5 \ldots$ & $\begin{array}{l}18.77 \\
18.59\end{array}$ & $\begin{array}{l}18.4 \\
18.6\end{array}$ \\
\hline
\end{tabular}

Table XXI.-Per cent water in butter samples found by using both the high-pressure oven method and the official chemists' method.

From these figures it appears that the results of duplicate analyses by the method here described agree as closely as do those obtained by the usual official chemical method.

"Farrington, E. H. Bul. 154. Wis. Expt. Sta., 1907. 


\section{BOOK II.}

MODERN BUTTER MAKING. 


\section{CHAPTER I.}

\section{DAIRY ARITHMETIC.}

A knowledge of the principles involved in arithmetical calculations pertaining to dairying was never more needed than at present. 


\title{
INDEX TO CHAPTER I.
}

\author{
PERCENTAGE AND DECIMALS.
}

Par. No.

Page.

1. Notation and numeration .............. 216

2. Expressing the value of a decimal..........217

3. Reading of decimals .................. 218

4. Principles of decimals $\ldots \ldots \ldots \ldots \ldots \ldots \ldots \ldots \ldots 219$

5. Multiplication of decimals ..............220

6. Special rules for multiplication of decimals...... 221

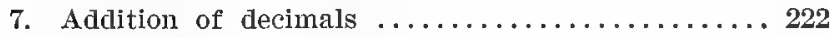

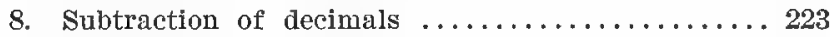

9. Division of decimals ................. 224

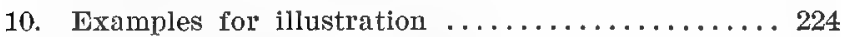

11. Reducing fractions to decimals............ 227

12. Reducing decimals to common fractions........ 227

13. Percentage . . . . . . . . . . . . . . . . 228

14. Various ways of expressing per cent.........229 


\section{CHAPTER I.}

\section{Decimals-Notation and Numeration.}

1. A decimal, or a decimal fraction, is a fraction whose denominator is $10,100,1,000$, etc.

2 . The denominator is always 10 or a multiple of 10 , and is not expressed as in common fractions, by writing it under the numerator, with a line between them, as $\frac{3}{10}, \frac{3}{100}, \frac{3}{1000}$. The denominator is always understood, the numerator consisting of the figures on the right of the unit figure of the number. In order to distinguish the unit figure, a period (.), called the decimal point, is placed between the unit figure and the next figure on the right. The decimal point may be regarded in two ways: First, as indieating that the number on the right is the numerator of a fraction whose denominator is $10,100,1,000$, etc.; and, second, as a part of the Arabic system of notation, each figure on the right being 10 times as large as the next succeeding figure, and 10 times as small as the next preceding figure, serving merely to point out the unit figure.

3. The reading of a decimal lepends upon the number of decimal places in it; $i$. e., upon the number of figures to the right of the mnit figure.

The first figure to the right of the unit figure expresses tenths.

The second figure to the right of the unit expresses hundreths. 
The third figure to the right of the unit figure expresses thousandths.

The fourth figure to the right of the unit expresses ten-thousandths.

The fifth figure to the right of the unit expresses hundred-thousandths.

The sixth figure to the right of the unit figure expresses millionths.

2. Table No. 1. The value of a decimal expressed in different ways.

$.3=\frac{3}{10}=3$ tenths.
$.03=\frac{3}{100}=3$ hundredths.
$.003=\frac{3}{1000}=3$ thousandths.
$.0003=\frac{3}{10000}=3$ ten-thousandths.
$.00003=\frac{3}{100000}=3$ hundred-thousandths.

$.000003=\frac{3}{1000000}=3$ millionths.

The first figure to the right of the unit is called the first decimal place; the second figure, the second decimal place, etc. We see in the above that the number of decimal places in a decimal equals the number of eiphers to the right of the figure 1 in the denominator of the equivalent fraction. This fact kept in mind will be of much assistance in reading and writing decimals. 
Whatever may be written to the left of a decimal point is a whole number. The decimal point affects only the figures to its right.

When a whole number and decimal are written together the expression is a mixed number. Thus, 8.12 and 17.25 are mixed numbers.

The relation of decimals and whole numbers to each other is clearly shown by the following table:

3. Table No. II.

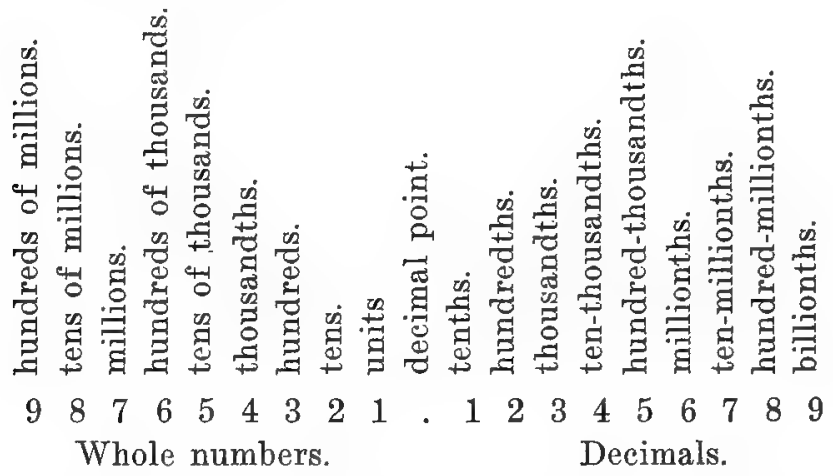

The figures to the left of the decimal point represent whole numbers; those to the right are decimals (fractions written in decimal form).

In both the decimals and whole numbers, the units place is made the starting point of notation and numeration. The decimals decrease an the scale of ten to the right, and the whole numbers increase on the scale of ten to the left. The first figure to the left of units is tens, and the first figure to the right of units is tenths. The second figure to the left of 
units is hundreds, and the seconds figure to the right is hundredths. The third figure to the left is thousands, and the third to the right is thousandths, and so on. The figures equally distant from units place correspond in name, but the decimals have the ending ths, which distinguishes them from whole numbers. The following is the numeration of the number in the above table: nine hundred eightyseven million, six hundred fifty-four thousand, three hundred twenty-one, and twenty-three million, four hundred fifty-six thousand, seven hundred eightynine hundred-millonths.

The decimals increase to the left, on the scale of ten, the same as whole numbers; for, beginning at, say, 4 thousandths, in the table, the next figure to the left is hundreths, which is ten times as great, and the next tenths, or ten times the hundreths, and so on through both decimals and whole numbers.

\section{Principles of Decimals.}

4. The value of a decimal is not changed by annexing or rejecting a cipher to the right of the last figure.

\section{Explanation.}

(a). The decimal .8 equals $8 / 10$, which reduced, equals $4 / 5$.

(b). Adding one cipher we get .80, which equals $80 / 100$, which reduced, equals $4 / 5$.

(c). Consequently, if both .8 and .80 can be reduced to $4 / 5$, they are equal and adding a cipher has not changed the value. 
II. A dorimal is divided by ten by inserting a "ipher betwern the derimal point (.) and the other figures to the right.

\section{Explanation.}

(a). The decimal .8 equals the proper fraction $8 / 10$, reduced (a) equals $4 / 5$.

(b). Inserting one cipher we get .08, which equals $8 / 100$, which equals (b) $4 / 50$. Ilence the fraction (a) (.8) is changed 10 times in value by inserting one cipher between the decimal point and $8=.08$.

III. Similarly a decimal is multiplied by 10 by rejecting a cipher from the first place between the decimal point (.) and the other figures to the right.

\section{Explanation.}

(a). The decimal .08 equals the proper fraction $8 / 100$, which reduced equals $4 / 50$.

(b). Rejecting the eipher .08 equals .8 , equals proper fraction $8 / 10$, which reduced equals $4 / 5$.

The latter by taking out the eipher multiplies the decimal ten times.

5. Multiplication of Decimals. $\Lambda$ general rule for the multiplication of decimals.

Rule. Place the multiplier under the multiplicand and disregarding the position of the decimal point, multiply as in whole numbers. In the product point off as many decimal places as there are decimal places in both the multiplier and multiplicand, prefixing ciphers if necessary. 


\section{Special rules for examples $a, b, c$ and $d$.}

Rule for example (a). In (a) there are two decimal p]aces in the multiplicand (the eipher does not count) and only one in the multiplier; hence $2+1=$ 3 decimal places are to be pointed off in the product (disregarding the cipher $(0)$ to the right of last figure not a cipher).

Rule for example (b). In (b) there is no decimal place in the multiplicand, but four in the multiplier. Therefore 4 decimal places are pointed off in the product.

Explanation and Solution of Problems (a) and (b).

(a). Multiply .250 by .10

Multiplicand .250

Multiplier $\quad .10$

Product $\quad \overline{.025}$ Ans.

(b). Multiply 258. by .0008

Multiplicand 258.

Multiplier .0008

Product $\quad \overline{.2064}$ Ans.

Rule for example (c). In (c) there are 3 decimal places in the multiplicand and none in the multiplier, therefore 3 decimal places are to be pointed off in the product.

Rule for example (d). In (d) there are 3 decimal places in the multiplicand and 2 in the multiplier. Therefore $3+2=5$ decimal places are to be pointed off in the product. 
(c). Multiply .928 by 18 .

Multiplicand .928

Multiplier $\quad 18$.

$\overline{7424}$

Product $\frac{928}{16.704}$ Ans.

(d). Multiply 2.101 by 1.28

Multiplicand 2.101

Multiplier $\quad \frac{1.28}{16808}$

Product $\frac{2101}{2.68928}$ Ans.

\section{Addition of decimals.}

Rule. Place the numbers to be added so that the decimal points shall be directly ander each other. Add as in whole numbers and place the decimal point in the sum directly under the decimal points above.

\section{Explanation and Solution.}

Decimals.

\section{.125}

.0004

.0101

.9256

1.0611 Sum Ans.

Mixed Decimals.

100.25

18.105

$1,000.240$

189.178

$\overline{1,307,773}$ Sum Ans. 
Whole Numbers.

284.

278.

1,001 .

1,810 .

3,373. Sum Ans.

\section{Subtraction of decimals.}

Rule. Place the subtrahend under the minuend so that the decimal points shall be in the vertical column. Subtract as in whole numbers and place the decimal point in the remainder directly under the decimal points above.

\section{Explanation and Solution.}

(a). Subtract .843 from 250.083

Minuend 250.083

Subtrahend $\quad .843$

Difference $\overline{249.240}$ Ans.

(b). Find the difference between 8.262 and .925 Minuend 8.262

Subtrahend .925

Difference 7.337 Ans.

(c). Subtract 2001. from 4282.

Minuend 4282.

Subtrahend 2001.

Difference $\overline{2281}$. Ans.

(d). Subtract .9589 from 1 .

Minuend 1.0000

Subtrahend $\quad .9589$

Difference . 0411 Ans. 
When there are more decimal places in the subtruhend than in the minuend place ciphers in the minuend above them and subtract as before.

9. Division of decimals. In this process we do not pay any attention to the decimal point until the division is performed, but divide exactly as in whole numbers. When divisor contains more decimal places than the dividend annex ciphers to the dividend until the number of decimal places in the dividend equals the number of decimal places in the divisor before dividing. Now subtract the number of decimal places in the divisor from the number of decimal places in the dividend and point off as many places in the quotient as there are units in the remainder, as shown in the sólution of the following examples:

\section{Examples for illustration.}

(a). Divide .840 by 30 .

(1) (2) (3)

30.). $840(.028$ Ans.

60

240

240

(1) Divisor.

(2) Dividend.

(3) Quotient.

In this example it was necessary to prefix only one cipher to 28 (or quotient), because there are only 3 derimal places in the dividend and none in the divisor. 
(b). Divide .00076 by 1.52

(1)

(2)

(3)

1.52).000760).0005 Quotient Ans.

760

In this example one eipher was annexed to the dividend (2) in order that 1.52 could be divided into 76 . Now we have 6 decimal places instead of.5

(2) (1)

in the dividend, leaving $6-2=4$ decimal places to be pointed off in the quotient.

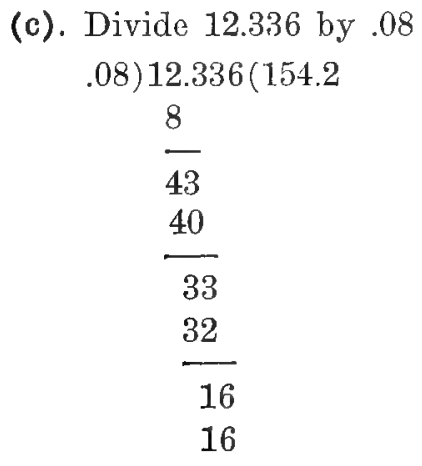

This example contains more decimal places in the dividend than in the divisor, therefore one decimal place is to be pointed off in the quotient.

(d). Divide 320 . by .40. $.40) 320.00$ (800. Ans.

320 
When the decimal places in the divisor exceed those in the dividend, annex as many eiphers to the dividend as will equal the decimal places in the divisor, and divide as in whole numbers. The quotient will be a whole number. In example $\mathbf{d}$ we added 2 ciphers to the dividend, giving the same number of decimal places in both dividend and divisor.

(e). Divide .375 by .016 $.015) .375$ (25. Ans.

30

$\overline{75}$

75

When the number of decimal places are the same in both dividend and divisor, as in example (e), the quotient is a whole number.

(f). Divide 2666 . by 141.

$$
\text { 141.) } 2666.000(18.907+
$$

\section{1}

1256

1128

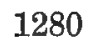

\section{9}

1100

987

113

When, as in the above example, the division has been carried on until all of the figures in the dividend have been used, annex ciphers and point off as many decimal places in the quotient as the decimal places in the dividend exceed those in the di- 
visor. If there is a remainder add the plus sign $(+)$ after the last figure in the quotient to indicate that it is not a complete result.

11. To reduce a fraction to a decimal.

(a). $2 / 5$ equals what decimal?

5) $2.0(.4$

2.0

(Proof: $\overline{.4}=4 / 10=2 / 5$ )

(b). What decimal is equivalent to $3 / 8$ ?

8) $3.000(.375$

24

60

56

40

40

(Proof: $.375=375 / 000=3 / 8$ )

(c). What decimal equals $4 / 25$ ?

$25) 4.00(.16$

25

150

150

Proof : $.16=16 / 100-4 / 25$ )

Rule. Annex ciphers to the numerator (the number above the line) and divide by the denominator (the number below the line) and point off in the quotient as many decimal places as ciphers added.

12. To reduce a decimal to a common fraction.

(a). Reduce .525 to a common fraction.

$$
\frac{525}{1,000} \div \frac{25}{25}=-\frac{5}{40}, \frac{5}{40} \div \frac{5}{5}=1 / 8 \text { Ans. }
$$


(b). Reduce .75 to a common fraction. $75 \quad 25$

$100 \quad 25$ Ans.

(c). Reduce .375 to a common fraction.

$\frac{375}{1,000} \div \frac{25}{25}=\frac{15}{40}, \frac{15}{40} \div \frac{5}{5}=3 / 8$ Ans.

Rule. Under the figures of the decimal, place one (1) and annex as many ciphers at the right as there are decimal places in the decimal. Reduce the resulting fraction to its lowest terms by dividing both numerator and denominator by a figure which will divide each of them without a remainder.

\section{Percentage.}

13. There is no business in which a knowledge of the fundamental principles of percentage is more necessary than in dairying. In most of the operations incident to the carrying on of the various phases of dairying, it is very convenient to know how to use the decimal or percentage system. Instead of using the common fractions as $1 / 2,1 / 4,2 / 5$ or $3 / 5$, it is easier to use $50 / 100,25 / 100,40 / 100$ and $60 / 100$, or the decimals $.50, .25, .40$ and .60 .

It is easier to compute with numbers having the denominator of 10 or some power of 10 , as 100 , 1,000 , etc., than it is to use the common fractions.

Percentage is a term applied to those arithmetical operations in which the number or quantity to be operated upon is supposed to be divided into 100 requal parts. 
Per cent means by the hundred. For instance: 5 $1^{12} \cdot$ cent of a number means 5 hundreths; that is, $5 / 100$ or .05 of that number; 5 per cent of 240 is $240 \times 5 / 100$, or $(240 \times 5) \div 100=12 ; 25$ per cent of 850 is $850 \times 25 / 100$, or $(850 \times 25) \div 100=213.5$.

When we say that the overun of a certain creamery is twenty per cent, we mean that for every 100 pounds of butter fat received, there was made 120 pounds of butter. If the creamery had received 800 pounds of butter fat and obtained an overrun of 20 per cent, the total butter made would be $800 \times 2(1 \div$ $100=160+800=960$ pounds of butter.

Solution : $800 \times 20=16,000 ; 16,000 \div 100=160 \mathrm{lbs}$. overrun; $800+160=960$ lbs. of butter made.

The sign per cent is \% and is read per cent. Thus, $8 \%$ is read eight per cent, $15 \frac{1}{2} \%$ is read fifteen and one-half per cent, ete.

When expressing the per cent of a number to be used in calculations, it is necessary to express it decimally instead of fractionally. Thus, instead of expressing $5 \%, 20 \%, 30 \%$ as $5 / 100,20 / 100,30 / 100$, express them as $.05, .20$, .30, etc.

The following table will show how per cent can be expressed:

14. Table No. III. Different ways of expressing per cent.

Per cent.

Decimal.

Fraction.

$1 \%$

.01

1 


\begin{tabular}{|c|c|c|}
\hline $20 \%$ & .20 & $\frac{20}{100}$ \\
\hline $75 \%$ & .75 & $\frac{75}{100}$ \\
\hline $150 \%$ & 1.50 & $\frac{150}{100}$ \\
\hline Per cent & Decimal. & Fraction. \\
\hline $1 / 4 \%$ & .0025 & $\frac{1 / 4}{100}$ or $\frac{1}{400}$ \\
\hline $1 / 2 \%$ & .005 & $\underline{1 / 2}$ or 1 \\
\hline & & $100 \quad 200$ \\
\hline $11 / 2 \%$ & .015 & $\stackrel{1 / 2}{=}$ or \\
\hline & & $100 \quad 200$ \\
\hline $162 / 3 \%$ & $.162 / 3$ & $\begin{array}{l}162 / 3 \\
\frac{100}{\text { or }} 1 / 6\end{array}$ \\
\hline $621 / 2 \%$ & .625 & $\begin{array}{l}621 / 2 \\
100\end{array}$ \\
\hline
\end{tabular}

The names of the different terms used in percentage are: The base, the rate, or rate per cent, the percentage, the amount and the difference.

Problem: Made $960 \mathrm{lbs}$. of buttcr from $800 \mathrm{lbs}$. of butter fat. The overrun is $160 \mathrm{lbs}$, the per cent of overrun is 20 .

The amount is 960 lbs., total butter made. The base is $800 \mathrm{lbs}$, total butter fat received. 


\section{The rate per cent is $160 \div 800$ or 20 per cent.}

\section{The percentage is $800 \times .20$ or 160 lbs. overrun.}

Percentage of overrun must not be confused with per cent of overrun. Percentage is the result obtained by multiplying the base ( $800 \mathrm{lbs}$.) by the per cent (.20) of overrun.

The per cent of overrun is obtained by dividing the percentage (160) by the base $(800)$, the total butter fat. 


\title{
INDEX TO CHAPTER II.
}

\author{
T I E O V ER R U
}

Par. No.

Page.

15. The overrun in butter making............ 233

16. Overrun influenced by market demands.........

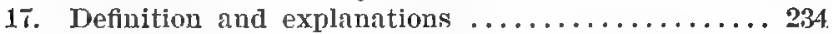

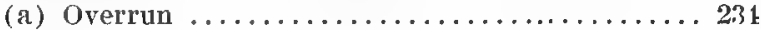

(b) Per cent of overrun ...............

(c) Percentage of overrun .............. 234

18. Cause of overrun ................... 234

19. Variation in overrun in whole milk creameries.... 235

20. Variations in overrun in hand separator cream

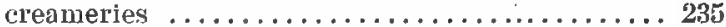

21. True and false overrun. True overrun........285

22. Market or false overrun................ 23\%

2:3. Overrun based upon market returns...........237

24. Overrun based um coniposition of butter.......237

25. IIow to find the per cent of butter fat in butter... 238

26. Hand separator cream overrun............ 238

27. Comparison of true overtun.............. 239

28. Market overrun ..................... 239

29. Overrun based upon composition of butter....... 239

30. Comparison of various overiuns.............240

31. Overrun for a whole milk creamery........... 241

32. Overrun for a hand separator cream creamery.... 242

33. Overrun on print butter................ 243

34. How underreading milk tests alffects the results in butter making ....................... 244

35. Extension of Table No. VI.............. 245

36. IIow overreading affects the overrun......... 245

37. Effect of underreading cream tests............246

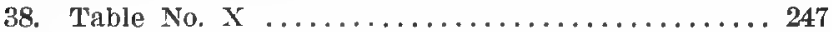

39. Butter fat in milk plus one-sixth equals the amount

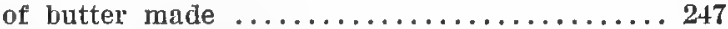

40. Effect of overreading cream tests........... 248

41. Continuation of Table XI ................ 249

42. Main factors affecting overrun............ 249 


\section{CIIAPTER II. \\ The Overrun in Butter Mraking.}

15. The overrun is to creamery butter making what the water gauge is to a boiler and a steam gauge to an engine. The amount of overrun a creamery obtains is a true index to its method of management. Upon the per cent of overrun obtained rests the success or failure of any creamery. It is important to know the per eent of overrun obtained as well as to know whether the overrun is a true or a false one. The creameryman should know whether calculations are based upon the number of pounds of butter fat received in milk or cream, and whether the weight of butter from the churn, or the weight taken from market returns constitutes the basis of overrun.

16. The overrun. The amount of overrun is influenced by the composition of the butter made, and varies according to the variation in the composition of the butter. The maximum overrun which can be obtained is governed by established standards of moisture and butter fat, and is locally influenced by the demands of commission houses for butter of a certain composition. In order to be able to demand a certain overrun from creameries, we must know what kind of butter their market demands, as well as what system of cream getting is practiced and the method of calculation employed. 
'The efficiency of the working of a creamery cannot be aceurately judged by the per cent of overrun obtain'd, unless intelligent inquiry has been made as to- the basis on which the overrun is calculated.

17. Definitions and explanations. (a). The overrun is the amount of butter made in excess of the amount of butter fat bought, whether this is in milk or cream. The amount of butter made in excess of the butter fat is called overrun because more butter is made than there is butter fat.

The term "yield" should not be used as meaning overrun in butter making. This term is properly applied in cheese making, meaning the amount of cheese made, either per hundred pounds of milk or per pounds of butter fat in one hindred pounds of milk.

(b). The per cent of overrun. By the per cent of overun we mean the quantity of butter made in excess of every hundred pounds of butter fat received and made into butter. When the overrun is eighteen per cent, it means that for every one hundred pounds of butter fat, one hundred and eighteen pounds of butter were made.

(c). Percentage of overrun By percentage of overrun we mean the quantiy of butter made in excess of any quantity of butter fat received and made into butter.

18. Cause of overrun. The overrun is due to the incorporation of salt, casein, moisture and other minor ingredients which enter into the composition of milk and are retained by the butter in the process of manufacture. The main factor affecting the 
overrun is the variation in the per cent of salt and moisture present in the butter.

19. Variations in overrun in whole milk creameries. Where whole milk is received, the overrun is influenced by errors in weighing, in sampling, in caring for samples, in reading tests, as well as by spilling milk, by inefficient separating, by not flushing separator bowls, by leaky vats, by lack of attention during pasteurizing, by improper ripening of cream, by insufficient cooling before churning, by churning at abnormal temperatures, by churning in a leaky churn, and by employing improper methods in washing, salting, working and handling the butter.

20. Variations in overrun in hand separator cream creameries. In a hand separator cream creamery we find all of the above causes affecting the overrun, except the loss sustained through mistakes in the separating if milk. In addition to these we have the spilling of eream during transit (it having been weighed at the farm by hauler), the taking of cream from cans on the way to creamery and favoritism shown patrons by hauler taking the sample of cream before the rinsings have been added and the cream weighed and recorded.

21. True and false overrun. True overrun. The only correct or true overrun is the overrun determined by basing calculations upon the total amount of butter fat received and the amount of butter made, according to its weight after being taken from the churn, packed and weighed. Any losses oecurring later, through the handling or holding of but- 
tor are temed either avoidable or unavoidable losses, and do not aftere the true overrun. In order 10 fully "xplain the diff'rence between the true and false overrun, one problem will be used as a basis for comparison and will be used in cach case to show the difference between the two.

Problem: Received in $20,000 \mathrm{lbs}$. of $4 / \%$ milk, 800 Ibs. of butter fat. From this $975 \mathrm{lbs}$. butter were made. What is the true overrun expressed both in per cent and pereentage Ans. Percentage of overrun 175 lbs. Per cent of overrun 21.875 per cent.

In figuring the true overrun for both whole milk and hand separator cream "reameries, 2 per cent losses are allowed for whole milk creameries and 1 per cent losses are allowed for hand separator cream creameries on the total butter fat recrived. Solution for whole milk creameries: 13ut1er fat receivel $=$ $800 \mathrm{lbs}$; ; butter made $=975 \mathrm{lbs}$; difference $-975-$ $800=175$ lbs.; per cent of overrun would be $(175 \div$ $800) \times 100=21.875 \%$.

Percentage of overrun would be: $800 \times 21.875 \div$ $100=175 \mathrm{lbs}$. The true overmu is $21.49 .5 \%$.

22. Market overrun. (False overrun.) Overrun calculations based upon any other basis than the above standarl are called "false," as, for instance, when the overrun is based upon the total fat reroived and the market weight of butter sold. From personal experienee, as well as from reports received from hundreds of creamcries, the losses sustained in the handling of buttor from the time it is taken from the rhurn, are assumed to bo about $1 \frac{1}{4} \mathrm{per}$ cent. When we include the loss of 2 per cent inci- 
dent to the handling of the butter fat before and during churning, the total loss wonld be about $31 / 4$ per cent of the total butter fat received in whole milk. In hand separator cream the loss is about 1 per cent less, except where a number of cream buying stations or wagon cream routes are connected with the creamery. In this case the difference between the total butter fat bought of the patrons and the butter fat actually recovered in the butter varies from 2 to 5 per cent of the total butter fat bought.

23. Overrun based upon market returns. To ilIustrate: Butter fat received $=800 \mathrm{lbs}$; butter made $=975$ lbs. Loss sustained $=1 \frac{1}{4} \%$ of 975 or $12.1875 \mathrm{lbs}$. Market return weight $=975-12.1875$ or $962.8125 \mathrm{lbs}$. Market overrun $=962.8125-800$ or 162.8125 lbs. $(162.8125 \div 800) \times 100=20.35+\%$.

True overrun: $21.875 \%$.

Market overrun: $20.35 \%$.

The differenee $=21.875-20.35$ or $1.525 \%$.

Another false overun frequently met with is the overrun obtained when calculations are based upon the composition of butter, no allowance being made for losses sustained at the creamery after churning or during transit.

24. Overrun based upon composition of butter. To illustrate. Butter fat received : 800 lbs.; loss at (reamery $2 \%(800 \times 2) \div 100=16$ lbs. looss.

Butter fat recovered in butter: $(800-16)$ or 784 lbs. Butter made: 975 lbs.

Per cent of overrun : $975-784=191 \mathrm{lbs}$. the overrun in lbs.; $191 \div 784=.2436$ the overrun for each 
pound of butter fat; and for every 100 lbs. the overrun is $.2436 \times 100=24.36 \%$.

Overrun based upon the composition of butter $24.36 \%$.

Market overrun (Par. 22-23) $20.35 \%$.

True overrun (Par. 21) $21.875 \%$.

Making $975 \mathrm{lbs}$. of butter from 784 lbs. of actually recovered butter fit, we get the l'ollowing composition: Fat 81.41 per cent, salt 2.70 per cent, casein 1 per cent and moisture 15.89 per cent, making up the total of 100 per cent.

25. How to find the per cent of butter fat in butter when the amount of butter made, butter fat received, and losses at the creamery are known, as per the given composition.

Butter made is $975 \mathrm{lbs}$; butter fat received is $800 \mathrm{lbs}$; l loss at creamery is 2 per cent.

Butter fat $=800$ Ibs.; Loss $=(800 \times 2) \div 100=$ $16 \mathrm{lbs}$.

Butter fat in butter is : $800-16$ or $784 \mathrm{lbs}$.

Butter made: $975 \mathrm{lbs}$.

Per cent butter fat in butter $=(784 \div 975) \times 100=$ $80.41+\%$. Ans.

The overrun on butter of such composition as tabulated below is: 24.36 per eent, based upon the composition of butter.

Fat 80.41 per cent, salt 2.70 per cent, easein 1 per cent, water 15.89 per cent. Total 100 per cent.

26. Hand separator cream overrun. Assuming that butter of the same composition is made as was made in the foregoing in a whole milk creamery, the loss at creamery being 1 per cent. 
The true overrun: Butter fat received: $800 \mathrm{lbs}$; butter fat in butter made: $80.41 \%$.

$(800 \times 1) \div 100=8$ lbs. loss ; $800-8=792$ lbs. fat made into buiter; $(792 \div 80.41) \times 100=984.94$ lbs. butter made. Per cent overrun $=984.94-800=$ $184.94 ;(184.94 \div 800) \times 100=23.12 \%$ overrun.

\section{Comparison of true overrun.}

Whole milk eream overrun: $21.875 \%$.

Hand separator cream overrun: $23.12 \%$.

Difference between the two: $1.245 \%$.

This means that for every 1 per cent of butter fat saved at the creamery, there is an approximate inerease of 1.245 per cent on the overrun, when butter is made in composition as above illustrated.

28. IMarket overrun. Ifand separator cream.

Problem: Received 800 lbs. butter fat. Made 984.94 lbs. butter. Loss $1 \frac{1}{4}$ per cent.

$\left(984.94 \times 1 \frac{1}{4}\right) \div 100=12.31$ lbs. loss.

Market return weight $=984.94-12.31=972.63 \mathrm{lbs}$.

Per cent overrun $=972.63-800=172.63 ;(172.63$ $\therefore 800) \times 100=21.58 \%$.

29. Overrun based upon composition of butter. Composition.

Butter fat 80.41

Salt $\quad 2.70$

Casein $\quad 1.00$

Water $\quad 15.89$

Total $\overline{100.00}$

Problem: Received 800 lbs. fat which made 984.94 lbs. butter; allowing $1 \%$ for mechanical losses. 
Solution: $(800 \times 1 \div 100=8$ Ihs. loss. $800-8=$ $792 \mathrm{lbs}$. butter fat in butter. Overrun $=984.94-792$ $=192.94 ;(192.94-7.92) \times 100=24.36 \%$.

30. Comparison of various overruns.

Whole Milk Cream.

True overrun

Market overrun

$21.875 \%$

Composition of butter, overrun $24.36 \%$

\section{Hand Separator Cream.}

True overrun

$23.12 \%$

Market overrun

$21.58 \%$

('omposition of butter, overrun $24.36 \%$

The above overruns are based upon the same amount of butter fat received in both milk and cream, and made into butter having the same composition. It was assumed that the tests were properly read.

The composition of butter was: Fat 80.41 per cent, salt 2.70 per cent, water 15.89 per cent, casein 1.00 per cent. For mechanical losses 2 per cent was allowed on whole milk cream, and 1 per cent was allowed on hand separator cream, on every $100 \mathrm{lbs}$. of butter fat received. For losses during transit 11/4 per cent was allowed on whole milk and on hand separator cream.

Since the overrun is influeneed by such a variety of conditions, and the calculations for determining it are basod upon both true and false standards, it is not to be wondered at that our practical dairymen, as well as others interested in dairying, do not more elearly understand this phase of the work. In orda $x$ to more dearly understand the results en- 
bodied in monthly statements issued by creameries, the creamery secretary and the butter maker should acquaint themselves with the fundamental principles involved, and the basis upon which the overrun is determined. Not only should the butter maker and creamery secretary know how to determine the overrun intelligently, but instructors and inspectors, who are supposed to instruct the dairymen, should understand this important part of creamery work. Demanding a given overrun, which is not in harmony with honest work, may lead many creamery operators to under read the test of milk and cream.

31. Overrun for a whole milk creamery. In the following, Table No. 4 , is shown the overrun that it is possible to get from $800 \mathrm{lbs}$. of butter fat when butter made varies in fat content.

\section{Variations in Overrun. \\ TABLE IV. \\ Variations in Overrun.}

\begin{tabular}{|c|c|c|c|c|c|c|}
\hline Per cent of lat In butter. & 80.41 & 81 & 82 & 83 & 84 & 85 \\
\hline Oreamery loss in per cent. & 2 & 2 & 2 & 2 & 2 & 2 \\
\hline Creamery loss in pounds.- & 16 & 16 & 16 & 16 & 16 & 16 \\
\hline Number of Ibs. of butter fat... & 784 & 784 & 784 & 784 & 784 & 784 \\
\hline Number lbs. of butter made.... & 975 & 967.9 & 956.09 & 944.58 & 933.38 & 922.35 \\
\hline Per cent of market shrinkage... & $11 / 4$ & $11 / 4$ & $11 / 4$ & $11 / 4$ & $11 \%$ & $11 / 4$ \\
\hline Pounds of market shrinkage-.- & 12.19 & 12.09 & 11.94 & 11.8 & 11.67 & 11.63 \\
\hline Market weight in pounds... & 962.8 & 955.81 & 944.05 & 931.78 & 822.38 & 910.82 \\
\hline $\begin{array}{l}\text { Per cent overrun on composition } \\
\text { of butter }\end{array}$ & 24.36 & 23.45 & 21.95 & 20.48 & 19.05 & 17.64 \\
\hline Per cent of market overrun & 20.35 & 19.48 & 18.00 & 16.47 & 15.29 & 13.84 \\
\hline Per cent of true overrun. & $21.87+$ & 20.99 & 19.51 & 18.07 & $16.75+$ & 16.29 \\
\hline Per cent of molsture & 15.88 & 16.30 & 14.80 & 13.30 & 12.30 & 11.30 \\
\hline Per cent of salt. & 2.70 & 2.70 & 2.70 & 2.70 & 2.70 & 2.70 \\
\hline Per cent of caseln._. & 1 & 1 & 1 & 1 & 1 & 1 \\
\hline
\end{tabular}


From the foregoing table it will be noticed that when a creamery obtains an overrun of 17-18 per cent, the butter must contain 82 per cent fat, 15 per cent water, 2.5 per cent salt and 1 per cent casein. Mechanical losses must not be more than 2.5 percent, and shrinkage or allowance during transit must not be more than 1 per cent of the butter manufactured. As the moisture increases and fat decreases in butter the overrun increases or decreases.

32. Overrun for a hand separator cream creamery. The following table shows the various overruns that a creamery can rightly obtain, using $800 \mathrm{lbs}$. of butter fat as a basis, and making butter which varies in the per cent of butter fat.

Various Overruns According to Per Cent Fat in Butter.

TABLE V.

Various Overruns, According Per Cent Fat in Butter.

\begin{tabular}{|c|c|c|c|c|c|c|}
\hline Por cent of fat In butter.-. & 80.41 & 81 & 82 & 83 & 84 & 85 \\
\hline Per cent of cresmery loss. & 1 & 1 & 1 & 1 & 1 & 1 \\
\hline $\begin{array}{l}\text { Pounds of butter fat creamery } \\
\text { loss }\end{array}$ & 8 & 8 & 8 & 8 & 8 & 8 \\
\hline Pounds of butter fat in & 702 & 792 & 792 & 792 & 792 & 792 \\
\hline Pounds of butter mac & 984.94 & 977.77 & 965.85 & 954.21 & 942.85 & 931.76 \\
\hline Per cent of market shrinkage & $11 / 4$ & $1 / 4$ & $11 / 4$ & $11 / 4$ & $11 / 4$ & $11 / 4$ \\
\hline Pounds of market shrinkage...... & 12.31 & 12.22 & 12.07 & 11.92 & 11.78 & 21.64 \\
\hline Market weight-pounds ....... & 972.63 & 965.55 & 953.78 & 942.29 & 831.07 & 920,12 \\
\hline $\begin{array}{l}\text { Per cent orerrun on composition } \\
\text { of butter }\end{array}$ & 24.36 & 23.45 & 21.85 & 20.48 & 19.05 & 17.64 \\
\hline Per cent of market overrun & 21.58 & 20.68 & 19.22 & 17.78 & 16.38 & 15.01 \\
\hline Per cent of true overrun. & 28.12 & 22.22 & 20.73 & 19.27 & 17.85 & 16.47 \\
\hline Per cent of molature... & 15.80 & 15.30 & 1480 & 13.80 & 12.30 & 11.30 \\
\hline Per cent of salt... & 2.70 & 2.70 & 2.70 & $\mathbf{2 . 7 0}$ & 2.70 & 2.70 \\
\hline er cent of casela. & 1 & 1 & 1 & 1 & 1 & 1 \\
\hline
\end{tabular}


When hand separator cream is delivered by patrons themselves; when testing and weighing are properly done, the overrun should come close to that indicated in the above table. When cream is bought through receiving stations the overrun is very often less than indicated in the foregoing table.

33. In the foregoing tables is found the per cent of overrun which can rightly be obtained under the conditions presented. When butter is printed or moulded direct from the churn, the weight of the butter then constitutes the basis on which to determine both the true and the market overrun. In this case there are no losses between the first weight and the market weight. Unless butter so put up does not have full weight, the overrun obtained when butter is moulded or printed is a trifle less than that obtained when butter is packed in tubs or boxes. When butter is printed, we may, for practical purposes, call the market weight the weight for the true overrun, thus having the true and the market overrun the same. In print butter there is no difference made between the creamery and the market weight.

The overrun is increased or derreased according as the per cent of salt is increased or decreased, unless the moisture is decreased or increased accordingly. The amount of casein is usually about the same, varying very slightly in butter made from good, well ripened and properly churned eream. As a rule the per cent of casein increases as the quality of the cream changes from good to poor. It can be 
increased considerably by merhanical methods, but this practice should be discouraged, not only on the grounds of honesty, but also for the reason that an increase of casein is usually attended by a poorer quality of butter. Casein should not be considered a factor in controlling the composition of butter.

\section{How under reading milk tests affects results} in buttermaking.

The following table shows how under-reading 4 per cent milk .1 to .5 per cent, when receiving 20,000 lbs. of milk, affects the overrun.

\section{TABLE VI.}

The Following Table Shows Hov Cnderreading $4 \%$ Mill .1 to $.5 \%$, when recciring 20,000 lbs. of Milk

- affects the ovrrun.

\begin{tabular}{|c|c|c|c|c|c|c|c|}
\hline $\begin{array}{c}\begin{array}{c}20,000 \\
\text { lbs, of } \\
\text { milk } \\
\text { received }\end{array} \\
\text { It tests }\end{array}$ & $\begin{array}{l}\text { Butter fat } \\
\text { in milk } \\
\text { according } \\
\text { to various } \\
\text { tosts }\end{array}$ & $\begin{array}{c}\text { Total } \\
\text { butter fat } \\
\text { in } \\
\text { butter }\end{array}$ & $\begin{array}{c}\text { Per } \\
\text { cont of } \\
\text { hutter } \\
\text { fat in } \\
\text { butter }\end{array}$ & $\begin{array}{l}\text { Pounde } \\
\text { of } \\
\text { butter } \\
\text { made }\end{array}$ & $\begin{array}{l}\text { Per cent } \\
\text { of true } \\
\text { over- } \\
\text { run }\end{array}$ & $\begin{array}{l}\text { Per cent } \\
\text { of fulse } \\
\text { overrun, } \\
\text { due to } \\
\text { under- } \\
\text { reading }\end{array}$ & $\begin{array}{c}\text { Per ent } \\
\text { of in- } \\
\text { cerease in } \\
\text { overrun, } \\
\text { due ton } \\
\text { under } \\
\text { reading }\end{array}$ \\
\hline $4 \%$ & 800 lbs. & 784 lbs. & 80 & 980 & 22.50 & ...... & $\ldots$ \\
\hline $3.9 \%$ & $780 \mathrm{lbs}$. & $784 \mathrm{lbs}$. & 80 & 980 & 22.50 & 25.64 & 3.14 \\
\hline $3.81 / r$ & Tuto lbs. & 784 lbs. & 80 & 980 & 22.50 & 28.94 & 6.44 \\
\hline $3.7 \%$ & $740 \mathrm{lbs}$. & $784 \mathrm{lbs}$. & 80 & 980 & 22.50 & 32.44 & 9.94 \\
\hline $3.6 \%$ & $72010 \mathrm{lbs}$. & $784 \mathrm{lbs}$. & 80 & 980 & 22.50 & 36.11 & 13.60 \\
\hline $3.5 \%$ & $700 \mathrm{lbs}$. & $7 \mathrm{k}+\mathrm{lbs}$. & 80 & 980 & $2=2.541$ & 40.00 & 17.50 \\
\hline
\end{tabular}

From this table it will bi seen that for every .1 per eent of under-reading of the milk test when buttor having 80 per cent butter fat is made, the overrun is increased 3.14 per cent, or an increase of 24.5 pounds of butter on 800 pounds of butter fat. 


\section{Extension of Table VI.}

TABLE VII.

\begin{tabular}{|c|c|c|c|}
\hline $\begin{array}{c}\text { Increase in butter lbs. } \\
.1 r^{\prime} \text { dally } \\
\text { under - reading }\end{array}$ & $\begin{array}{l}\text { Increase per } \\
\text { day at } 25 c \\
\text { per pound }\end{array}$ & $\begin{array}{l}\text { Increase in } \\
\text { one year of } \\
300 \text { clays }\end{array}$ & $\begin{array}{c}\text { Increase in one } \\
\text { year when } \\
40,000 \text { pounds of } \\
\text { milk is received } \\
\text { daily }\end{array}$ \\
\hline $\begin{array}{l}.1 \%=24.5 \mathrm{lbs} . \\
.2 \%=49 . \mathrm{bs} . \\
.3 \%=73.5 \mathrm{lbs} . \\
.4 \%=08.1 \mathrm{ls} . \\
.5 \%=122.5 \mathrm{lbs} .\end{array}$ & $\begin{array}{l}\$ 6.125 \\
12.25 \\
18.37+ \\
21.50 \\
30.625\end{array}$ & $\begin{array}{l}\$ 1,837.50 \\
3,675 . \\
5,511 \\
7,350 \\
9,186\end{array}$ & $\begin{array}{r}\$ 3,675 . \\
7,350 . \\
11,022 . \\
14,7(40 . \\
18,372 .\end{array}$ \\
\hline
\end{tabular}

If a person is not properly trained in reading tests, or is not careful in making the tests, it can easily be seen from the foregoing tables that great losses can be caused, both to the patrons and shareholders of a creamery. The lower the test of milk, the greater is the difference in overrun for every .1 per cent of over or under-reading.

\section{How over-reading affects the overrun.}

TABLE VIII.

Hou Overreading Affects the Overrun.

\begin{tabular}{c|c|c|c|c|c}
\hline $\begin{array}{c}\text { Overread- } \\
\text { ing test } \\
\text { by .1. }\end{array}$ & $\begin{array}{c}\text { Butter fat in } \\
20,000 \text { lbs. of } \\
\text { milk }\end{array}$ & $\begin{array}{c}\text { Pounds of } \\
\text { butter } \\
\text { made }\end{array}$ & $\begin{array}{c}\text { Per cent } \\
\text { of true } \\
\text { overrun }\end{array}$ & $\begin{array}{c}\text { Per cent } \\
\text { of false } \\
\text { overrun }\end{array}$ & $\begin{array}{c}\text { Per cent } \\
\text { of decrease } \\
\text { in overrun }\end{array}$ \\
\hline $\begin{array}{c}\text { Correct } \\
\text { test }\end{array}$ & & & & & \\
$4 \% \%$ & $800 \mathrm{lbs}$. & 980 & 22.50 & $\ldots \ldots$ & $\ldots$ \\
$4.1 \%$ & $820 \mathrm{lbs}$. & 980 & 22.50 & 19.51 & 2.99 \\
$4.2 \%$ & $840 \mathrm{lbs}$. & 980 & 22.50 & 16.67 & 5.83 \\
$4.3 \%$ & $860 \mathrm{lbs}$. & 980 & 22.50 & $13.95+$ & 8.55 \\
$4.4 \%$ & $880 \mathrm{lbs}$. & 980 & 22.50 & 11.36 & 11.14 \\
$4.5 \%$ & $900 \mathrm{lbs}$. & 980 & 22.50 & 8.88 & 13.62 \\
\hline
\end{tabular}

By reading the test :1 per cent too low, on 4 per cont milk the overrun is increased 3.14 per cent, Table VI.; and by reading the test .1 per cent too high on 4 per cent milk, the overrun is reduced 2.99 
per '"nt, Table No. VIII. This shows how easily the overun may be reduced by reading the test while the test is too hot, and how easily it can be jnereased by reading the test when it is too cold, or by including the full meniscus, or by not including the meniscus in reading milk tests. Not only is the overrun affected by the above mentioned conditions, but not infrequently by deliberate over or underreading of milk or cream tests.

37. The effect of under-reading cream tests. Table No. IX. Assuming that 800 lbs. of butter fat is received in 3,200 lbs. of cream testing 25 per cent. Butter made contains 80 per cent butter fat and the loss incident to its manufacture is 1 per cent.

TABLE IX.

Jh" siffert of Underreading Cream Tests.

\begin{tabular}{|c|c|c|c|c|c|c|c|}
\hline 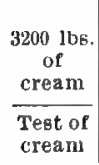 & $\begin{array}{l}\text { No. of } \\
\text { lbs. of } \\
\text { butter } \\
\text { fat in } \\
\text { creain }\end{array}$ & $\begin{array}{l}\text { Total } \\
\text { lbs. of } \\
\text { butter } \\
\text { fat in } \\
\text { butter }\end{array}$ & $\begin{array}{c}\text { Per cent } \\
\text { of } \\
\text { butter } \\
\text { fat in } \\
\text { butter }\end{array}$ & $\begin{array}{l}\text { No. of } \\
\text { lbs. of } \\
\text { butter } \\
\text { made }\end{array}$ & $\begin{array}{c}\text { Per cent } \\
\text { of } \\
\text { true } \\
\text { overrun }\end{array}$ & $\begin{array}{l}\text { Jer cent } \\
\text { of false } \\
\text { overrun } \\
\text { due to } \\
\text { reduced } \\
\text { reading }\end{array}$ & $\begin{array}{l}\text { Per cent } \\
\text { fucrease } \\
\text { of } \\
\text { overrun } \\
\text { per .5\% } \\
\text { reduced } \\
\text { roadlng }\end{array}$ \\
\hline $\begin{array}{c}\text { Correct } \\
\text { test }\end{array}$ & & & & & & & - \\
\hline (25) \% & 800 & 792 & 80 & 990 & 23.75 & & $\ldots$ \\
\hline $24.5 \%$ & 784 & 792 & 80 & 990 & 2.3 .7 .5 & 210.27 & 2.712 \\
\hline $24 \%$ & 768 & 792 & 80 & 090 & 23.75 & 28.90 & 515 \\
\hline $23.5 \%$ & 752 & 792 & 80 & 990 & 23.75 & 31.64 & 7.89 \\
\hline $2: 3 \%$ & $7: 36$ & 795 & 80 & 900 & 23.75 & 34.51 & $10.74 i$ \\
\hline $22.5 \%$ & 720 & 792 & 80 & 990 & $23.7 \pi$ & 37.50 & 13.75 \\
\hline
\end{tabular}

The above table shows that for every .5 per cent reduction in reading 25 per cont cream, the overrun is increased by about 2.7 per cent. The higher the cream tests are, the less is the increase in overmun due to reduced reading. 
38. Table No. $\mathbf{X}$, continuation of table No. IX. Showing increase in lbs. and value at $25 \mathrm{c}$ per $1 \mathrm{lb}$.

\section{TABLE $\mathrm{X}$.}

Continuation of Alove Table No. IX. Showing Increase in lbs. and Value at 25 cents per $l b$.

\begin{tabular}{c|c|c|c|c}
\hline $\begin{array}{c}\text { Readings re- } \\
\text { duced from } \\
5 \% \text { to } 2.5 \%\end{array}$ & $\begin{array}{c}\text { Butter lbs. in- } \\
\text { crease due } \\
\text { to reduced } \\
\text { reading daily }\end{array}$ & $\begin{array}{c}\text { Value at } \\
25 c \text { per lb. } \\
\text { daily }\end{array}$ & $\begin{array}{c}\text { Value during } \\
\text { ons year of } \\
300 \text { days }\end{array}$ & $\begin{array}{c}\text { Value when } \\
\text { bituo lbs. 1s re- } \\
\text { celved daily for } \\
\text { one year }\end{array}$ \\
\hline $.5 \%$ & 19.8 & $\$ 4.95$ & $\$ 1,485$. & $\$ 2,970$ \\
$1.5 \%$ & 39.6 & 9.80 & $2,940$. & 5,880 \\
$1.5 \%$ & 59.4 & 14.85 & $4,455$. & 8,910 \\
$2.5 \%$ & 79.2 & 19.80 & $5,940$. & 11,880 \\
$2.5 \%$ & 99. & 24.75 & $7,425$. & 14,850 \\
\hline
\end{tabular}

That great care should be exercised at cream buying stations is clearly shown in the foregoing tables. The amount of butter fat bought should check up to within 2 per cent of the amount found to be in the cream when tested at the central station. When cream is bought at a receiving station the overrun is very likely to be from 2 per cent to $2 \frac{1}{2}$ per cent, or even 4 per cent less than when sream is delivered directly to the creamery.

39. Butter fat in milk plus one-sixth equals the amount of butter made.

The approximate amount of butter which can be made from any given number of pounds of butter fat is found by adding one-sixth of itself to the number of pounds of butter fat. This is true when butter having about $821 / 2$ per cent butter fat is made. This was agreed upon by the Association of American Agricultural Colleges and Experiment Stations at their ninth annual convention. 
The amount of butter which can be made from any given amount of butter fat also depends largely upon the skill of the operator and upon the composition of the butter made; therefore the results obtained may be either higher or lower than results given in the preceding pages.

The per cent of overrun is no true indication of the composition of butter, nor is the composition of butter a true indication of the per cent of overrun.

40. The effect of overreading cream tests. Assuming that $800 \mathrm{lbs}$. of butter fat are received in 3,200 lbs. of cream testing 25 per cent. Butter made contains 80 yer cent butter fat. Loss incident to manufacture is 1 per cent.

\section{TABLE $\dot{\mathrm{X}} \mathrm{I}$.}

The Effect of Overreading Oream Tests.

\begin{tabular}{|c|c|c|c|c|c|c|c|}
\hline 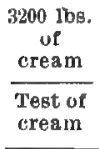 & $\begin{array}{l}\text { No, of } \\
\text { lbs. } \\
\text { butter } \\
\text { fat in } \\
\text { cream }\end{array}$ & $\begin{array}{l}\text { Total } \\
\text { lbs. of } \\
\text { butter } \\
\text { lat In } \\
\text { butter }\end{array}$ & $\begin{array}{c}\text { Per cent } \\
\text { of } \\
\text { butter } \\
\text { fat in } \\
\text { butter }\end{array}$ & $\begin{array}{l}\text { No. of } \\
\text { lbs. of } \\
\text { butter } \\
\text { made }\end{array}$ & $\begin{array}{l}\text { Per cent } \\
\text { of false } \\
\text { overrun, } \\
\text { due to } \\
\text { over- } \\
\text { reading }\end{array}$ & $\begin{array}{c}\text { Per cent } \\
\text { of } \\
\text { true } \\
\text { overrun }\end{array}$ & $\begin{array}{l}\text { Percent } \\
\text { of } \\
\text { reduc- } \\
\text { tlon of } \\
\text { overrun } \\
\text { by } .5 \%\end{array}$ \\
\hline \multicolumn{8}{|l|}{$\begin{array}{c}\text { Correct } \\
\text { test }\end{array}$} \\
\hline $25 \%$ & 800 & 792 & 80 & 990 & $\cdots$ & 23.75 & .... \\
\hline $25.5 \%$ & 816 & 792 & 80 & 990 & 21.32 & 23.75 & 2.43 \\
\hline $26 \%$ & 832 & 702 & 80 & 990 & 18.97 & 23.75 & 4.78 \\
\hline $26.5 \%$ & 848 & 792 & 80 & 990 & 16.74 & 23.75 & 7.01 \\
\hline $27 \%$ & 864 & 792 & 80 & 920 & 14.58 & 23.75 & 9.17 \\
\hline $27.5 \%$ & 880 & 792 & 80 & 990 & 12.50 & 23.75 & 11.25 \\
\hline
\end{tabular}

In the foregoing table we find that for every .5 per cent overreading the overrun is reduced about 2.43 per cent and grows slightly less for every .5 per cent as the cream increases in richness of butter fat. 
41. Continuation of table XI. showing a decrease in overrun in pounds of butter made, and the amount of loss at $25 \mathrm{c}$ per pound, when $3,200 \mathrm{lbs}$. of 25 per cent cream is read too high as in the preceding table.

TABLE XII.

\begin{tabular}{c|c|c|c}
\hline $\begin{array}{c}\text { Decrease in lbs. of } \\
\text { butter per .5 per cent } \\
\text { overreadlug of cream } \\
\text { tests daily }\end{array}$ & $\begin{array}{c}\text { Dally loss at } \\
25 \mathrm{c} \text { per 1b. }\end{array}$ & $\begin{array}{c}\text { Loss per year } \\
\text { of 300 days }\end{array}$ & $\begin{array}{c}\text { Loss ver year } \\
\text { when 40,000 lbs. } \\
\text { of unilk are } \\
\text { recelved dally }\end{array}$ \\
\hline $.5 \%=20 \mathrm{lbs}$. & $\$ 5.00$ & $\$ 1,500$ & $\$ 3,000$ \\
$1 . \%=40 \mathrm{lbs}$. & 10.00 & 3,000 & 6,000 \\
$1.5 \%=60 \mathrm{lbs}$. & 15.00 & 4,500 & 9,000 \\
$2 . \%=80 \mathrm{lbs}$. & 20.00 & 6,000 & 12,000 \\
$2.5 \%=100 \mathrm{lbs}$. & 25.00 & 7,500 & 15,000 \\
\hline
\end{tabular}

The necessity of proper training for operating the Babcock test is again emphasized by the results presented in the foregoing tables. When we consider the foregoing chapter in its broadest sense it becomes evident that more and better training are necessary for the creamery operator, as well as better laws pertaining to this phase of the dairy industry. This is necessary for the protection of those who wish to perform their work honestly amidst unserupulous persons. Taking a Dairy School course is undoubtedly the best way of gaining the knowledge necessary for properly performing all the operations necessary for the handling of the Babcock test.

\section{Main factors affecting the overmun.}

(a) Factors causing an increase in overrun:

1. Under-reading cream or milk tests.

2. Reading tests when too cold.

3. Not whirling test bottles long enough. 
4. Short weight of test samples.

5. Reducing the per cent of fat in butter.

6. Increasing the $p$ ( $r$ cent of moisture in butter.

7. Increasing the per cent of casein in butter.

8. Reducing losses to a minimum.

9. Giving short milk or cream weights.

10. Churning at high temperatures.

11. Working butter in wash water.

12. Washing butter with warm water.

13. Overworking butter in water when soft.

(b) Factors causing a decrease in overrun:

1. Overreading cream or milk tests.

2. Reading tests when sample is too hot.

3. Black specks and flocules in sample tested.

4. Overweight of test sample.

5. Too high per cent of fat in butter.

6. Too dry butter.

7. Decreasing the per cent of cascin.

8. Spilling milk or cream or using a leaky churn.

9. Giving over woight in milk or cream.

10. Churning very rold cream and washing in very cold water.

11. Working hard butter at intervals instead of continuously until done.

12. Draining butter too dry and adding cold, dry salt.

13. Adding salt to crosm or wash water. 
diver vulber is lldue:

1. Dropping small pieces of butter during packing.

2. Allowing butter to stick to churn, ladles and printers.

3. Leaky butter, losing water during handling and transit.

4. Repacking hardened butter.

5. Allowing butter to harden in churn before packing.

6. Incorrect weighing of butter when packed. 


\section{INDEX TO CHAPTER III. \\ STANDARDIZATION OF MILK AND CREAM AND \\ BUTTER FAT VALUES.}

I'al. No.

I'age.

43. Corlect stimlardization $\ldots \ldots \ldots \ldots \ldots \ldots \ldots \ldots$ 25;

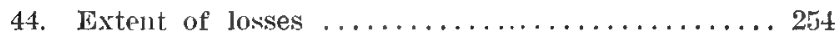

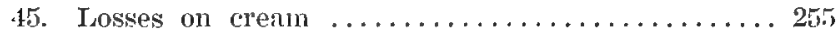

46. Problems in standardization............. 257

47. When whole milk is userl.............. 26:3

48. Standardizing whole milk .............. 263

49. How to use viscogen as a thickening agent...... 265

50. A few suggestions on the use of viscogen in com-

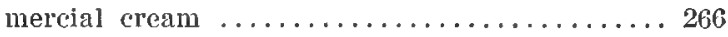

51. Butter fat values $\ldots \ldots \ldots \ldots \ldots \ldots \ldots \ldots \ldots \ldots . \ldots \ldots$

52. Problems with explanations ............. 268

53. Comparative values .................. 269

54. The value of butter fat in cream........... 270 


\section{CHAPTER III.}

\section{Standardization of Milk and Cream and Butter Fat Values.}

\section{(a) Standardization of milk and cream.}

43. Correct standardization of milk and cream is without doubt a very important factor in the successful handling of these products. The butter fatthe least variable constituent of milk-is the most valuable, hence the necessity of knowing accurately the per cent of butter fat contained in milk and cream.

Many instances are known of milk being sold containing much more butter fat than the price received for it would warrant without sustaining losses. On the other hand, without testing or standardizing milk, it is sometimes sold containing less butter fat than the legal standard. When the butter fat content is too low the consumer is the loser, and the sale of such milk is illegal; when the butter fat content is too high, the dealer is the loser.

Where the milk is bought for a certain consideration per hundred pounds, or by the fat content, based upon the Babcock test, and part of it is sold in the form of cream, the necessity of knowing the exaet fat content is important. In many instances this milk is run through a separator with the machine so adjusted as to skim about the desired per cent of fat. Even with the milk uniformly heated, the speed regular, and the same rate of inflow, a great variation in the fat content of cream will be noticed. Even 
when all conditions are exactly the same there is always a little difference in the fat content of the "r'am. With some kinds of separators this variation in fat content is not nearly so great as with others, but the variation is always great enough to make it impossible to go by guess work and thereby incur losses which might be avoided by a little mathematiral calculation. When once the general milk draler becomes conscious of the fact that his competitor, by adopting the Babcock test, a method of stundardization, and up-to-date dairy machinery makes great' $\mathrm{r}$ profits in his line of work, he will not fail to learn and adopt methods which will put him on the samr basis as his neighbor. Where milk and cream are bought only on the butter fat basis, they crertainly must be sold on the same basis in order to avoid losses to the dealer, or cheating the consumers.

44. The extent to which losses may be incurred by buying on the butter fat basis and selling by weight or moasiors may radily be seen by the following: A milk and cream establishment receives about 20,000 pounds of milk per day, testing 4.5 per r'nt of butter fat. This milk, at an average price of $20 \mathrm{c}$ per pound of butter fat, would cost $\$ 180$, figured as follows. 20,000 pounds of 4.5 per cent $\div$ $100=900$ lbs. of buttor fat, which, at $20 \mathrm{c}$, would be $\$ 180$. One-half of this 20,000 pounds of milk is sold as milk. Under contract the milk should contain 3.8 per "ent of buttre fat; but when sold containing 4.5 per rent insturl of 3.8 por ant the loss sustainad by the dealer would be 4.5 per rent-3.8 or .7 per 
cent, or 70 Ibs. of butter fat. Seventy pounds of butter fat at $20 \mathrm{c}$ a pound equals $\$ 14$ loss each day on 10,000 lbs. of milk.

45. The other $10,000 \mathrm{lbs}$. of milk is separated and sold in the form of cream at $20 \mathrm{c}$ a quart. The separator is adjusted so as to skim cream testing 20 per. cent, but instead of skimming a 20 per cent cream, it skims a cream which tests 22 per cent. The loss in this case at $20 \mathrm{c}$ a quart would be as follows: The total fat in the cream is 450 lbs. $450 \div 20$ per cent $X$ $100=2,250 \mathrm{lbs}$. of 20 per cent cream. The number of pounds of 22 per cent cream would be $450 \div 22 \times$ 100 , or 2,045 . The difference would be $2,250-2,045$ or 205 lbs. of cream. This would equal about 96 quarts, which, at 20e a quart, amounts to \$19.20. The loss per day is--on the milk $\$ 14$, on the cream, $\$ 19.20$, making a total loss of $\$ 33.20$. On 300 working days per year this would amount to a loss of $\$ 9,960$.

Suppose such a sized plant employs 15 men at an avi'age wage of $\$ 60$ per month. These losses alone would practically pay all but one of these men.

Bufore actually figuring it out the variation in the fat content seems unimportant, but the above calculation shows that it amounts to rather a snug sum in a year. And in 20 years it would amount to $\$ 199,200$ - a handsome sum, indeed, and enough to make even two partners feel comfortable and look cheerfully toward coming old age.

This illustration bears out the statement that great losses can be incurred by buying milk on the basis of the butter fat content and selling by weight or 
measure without regard to the fat content. In order to do justice to both the dealer and the consumer, milk should be bought and sold on the basis of the butter fat content. A butcher would not sell the different cuts of meat for the same price, nor would a miller sell fancy flour for the same price as the poorer grades. But does the average milk dealer ever think of selling milk and cream on an accurate butter fat basis? Many consumers of milk and cream do not know any difference between rich and poor cream, and the expression "pure cream" usually conveys the meaning of a rich, heavy cream with a high per cent of butter fat.

I am personally acquainted with some dealers and have a knowledge of their methods of handling milk and cream. The milk is separated and the richness of the cream regulated by the cream screw; the cream at times varies from 2 to 3 per cent of that desired by the dealer. From the methods generally employed in handling milk and preparing it for the market, it seems that a method by which milk and cream can be casily and accurately made to test the - desired per cent of butter fat is indispensable. This is known as standardization. Standardization, as applied to milk and cream, is a process by which skim milk can be extracted from or added to milk or cream, or whole milk or cream can be added to milk or cream to raise or lower the per cent of butter fat to the desired standard.

The following problems with rules and analyses will show the methods which may be employed in standardizing milk and cram: 
46. Problems in standardization of milk and cream.

1. When cream is too low in per cent of fat.

Rule I. Subtract the per cent of fat in the cream to be raised to a higher per cent from the desired per cent.

Rule II. Subtract the desired per cent of fat from the per cent of fat in the cream to be used to add to the cream; divide the first difference by the second difference and multiply the quotient by the number of pounds of thin cream to be raised to a higher per cent of fat. The result is the number of pounds of higher testing cream to be added to the thin cream to be raised to a higher per cent of fat. The total cream would be obtained by adding the number of pounds of rich cream to the number of pounds of thin cream.

Problem: 1,000 lbs. of 25 per cent testing cream is to be raised to 40 per cent with eream testing 50 per cent butter fat. Find how many pounds of the 50 per cent cream must be added to the 25 per cent cream to make it test 40 per cent.

Solution: 40 per cent-25 per cent=15 per cent. $15 \div 10=1.5$. 50 per cent -40 per cent $=10$ per cent. $1,000 \times 1.5=1,500 \mathrm{lbs}$, the number of pounds of 50 per cent cream to be added to 25 per cent cream to raise it to 40 per cent.

One thousand pounds plus $1,500=2,500$ pounds $=$ the whole amount of cream testing 40 per cent.

Proof: $1,000 \mathrm{lbs} . \times 25$ per cent $=250 \mathrm{lbs}$. of butter fat; $1,500 \mathrm{lbs} . \times 50$ per cent $=750 \mathrm{lbs}$. of butter fat; 750 plus $250=1,000$ lbs., total butter fat; $2,500 \mathrm{lbs}$. $\times 40$ per cent $=1,000 \mathrm{lbs}$. 
2. When cream is too high in per cent of fat.

Rule I. From the test of the rich cream subtract the test of the desired cream.

Rule II. Subtract the test of the thin cream to be added to dilute rich cream, from the desired test. Divide the first difference by the second and multiply the quotient by the number of pounds of rich cream to be lowered, and the result will be the number of pounds of thin cream to be added to the rich cream to reduce it to the desired test. The total number of pounds of cream may be found by adding the number of pounds of thin eream to the number of pounds of rich eream.

Problem: 1,000 lbs. of 50 per cent testing cream is to be diluted to 40 per cent with cream testing 25 per cent. How many pounds of 25 per cent must be added to give the desired test?

Solution: 50 per cent -40 per cent $=10$ per cent. 10 per cent $-15=66666$ plus. 40 per cent -25 per cent $=15$ per cent. $1,000 \times .66666=666.66$ plus pounds. $666.66=$ the number of pounds of thin cream to be added to reduce the heavy cream to 40 per cent. Total cream equals 1,000 lbs. plus 666.66 pounds or $1,666.66+$ lbs.

Proof: $1,000 \mathrm{lbs} \times 50$ per cent $=500 \mathrm{lbs}$. of fat in $1,000 \mathrm{lbs}$. of 50 per cent cream.

$666.66 \mathrm{lbs} . \times 25$ per cent $=166.66 \mathrm{lbs}$. of fat in $666.66 \mathrm{lbs}$. of 25 per cent cream.

$500+166.66=666.66$, total pounds of fat in cream.

3. When a definite number of pounds of cream of a certain richness is wanted and cream or milk of less butter fat content is on hand, to find the ratio 
of number of pounds of the two kinds to mix together to reduce the richer cream to the butter fat content desired :

Rule I. Subtract the per cent of fat in the eream to be used to add to heavy cream to dilute it from the desired test.

Rule II. Subtract the per cent of thin cream from the test of the rich cream and divide the remainder into the result obtained in the first subtraction. Multiply the quotient by 100 and the result will be the per cent of the rich cream to be used in standardizing the cream.

Problem. How many pounds each of 50 per cent and 25 per cent cream must be mixed together to produce $1,000 \mathrm{lbs}$. of cream testing 40 per cent.

\section{Solution:}

40 per cent-25 per cent $=15$ per cent.

15 per cent $\div 25$ per cent $=.6$ per cent.

50 per cent-25 per cent $=\mathbf{2 5}$ per cent.

$.6 \times 100=60$ per cent, the per cent of 50 per cent cream to be used for the standardization of cream. $1,000 \mathrm{lbs}$. of 40 per cent is wanted. Sixty per cent of 1,000 lbs. equals 600 lbs., the number of pounds of 50 per cent cream necessary. 40 per cent of the 25 per cent cream is to be added to the rich cream to reduce the test to 40 per cent.

Proof: $1,000 \mathrm{lbs}$. of 40 per cent eream $=400 \mathrm{lbs}$. butter fat.

60 per cent of $1,000 \mathrm{lbs}=600 \mathrm{lbs}$. of 50 per cent cream to be used.

40 per cent of $1,000 \mathrm{lbs}=400 \mathrm{lbs}$. of 25 per cent cream to be used. 
$600 \mathrm{lbs}$. of 50 per cent cream $=300 \mathrm{lbs}$. butter fat. 400 lbs. of 25 per cent cream $=100 \mathrm{lbs}$. butter fat. 400 lbs. total butter fat.

4. To find the ratio of the number of pounds of cream and skim-milk to be mixed to give a definite quantity of a definite richness :

Rule I. Determine the quantity of fat in the desired cream by multiplying the number of pounds of cream wanted by the desired test and dividing the results by 100 .

Rule II. Divide the number of pounds of butter fat by the test of the cream on hand for use in standardizing, and multiply the quotient by 100 . The result will give the number of pounds of cream to be used. The difference between the amount of cream desired and the amount of rich cream to be used will be the amount of skim milk to be added to the rich cream to produce the desired test.

Problem: $600 \mathrm{lbs}$. of 30 per cent cream is wanted. ITaving cream on hand testing 40 per cent, and skimmilk, find how many pounds of each are needed to produce $600 \mathrm{lbs}$. of 30 per cent cream.

Solution: $600 \mathrm{lbs} . \times 30$ per cent $\div 100=180 \mathrm{lbs}$. of butter fat in the quantity of cream desired.

180 lbs. $\div 40$ per cent $\times 100=450$ lbs. of 40 per cent - cream to be used. $600 \mathrm{lbs} .-450 \mathrm{lbs}=150 \mathrm{lbs}$. of skim milk to be mixed with cream to reduce it to 30 per cent cream. $450 \mathrm{lbs}$. plus $150 \mathrm{lbs}=600 \mathrm{lbs}$. of cream testing 30 per cent.

Proof: Butter fat in cream desired is $(600 \times 30)$ $\div 100=180$ lbs. Butter fat in mixture of 40 per cent cream and skim-milk is $(450 \times 40) \div 100=180 \mathrm{lbs}$. 
Butter fat in skim-milk none. The butter fat in the desired cream and in the mixture are the same; therefore calculations are correct.

In order to prove whether the calculations have been correctly made, determine the fat in the two mixtures, and the fat in the desired cream. If calculations have been correctly made, both results should be the same.

5. Three different methods which may be used to reduce the per cent of butter fat by adding skimmilk.

(a) Rule I. Multiply the number of lbs. of cream to be diluted by the per cent of butter fat contained in the same, divide the product by 100 . The quotient should then be multiplied by 100 and divided by the desired test. The difference between this result and the original amount of cream is the quantity of skimmilk to be added.

Problem: 1,000 lbs. of cream testing 30 per cent butter fat is to be reduced to 25 per cent by adding skim-milk. How many pounds of skim-milk must be added?

\section{Solution:}

\section{$1,000 \times 30$}

300 lbs. butter fat in 1,000 lbs. 30 per 100

cent cream.

$300 \times 100$ 25 sired per cent of butter fat.

$1,200-1,000==200 \mathrm{lbs}$. of skim-milk to be added to the original cream to reduce it to 25 per cent cream. 
(b) Rule II. Multiply the difference between the test of the original cream by the number of lbs. of cream and divide the product by 100. Divide the rrsult by the desired test, multiply the quotient by 100 and the result will be the number of pounds of skim-milk to be added to the eream to reduce the fat to the disired per cent.

Problem: 1,000 lbs. of cream testing 30 per cent is to be reduced to 25 per cent by adding skim milk. How many pounds of skim-milk must be added?

\section{Solution :}

$$
\begin{aligned}
& 30--25=5 \\
& 1,000 \times 5=5,000 . \\
& 5,000 \div 100=50 .
\end{aligned}
$$$$
50 \div 25=2 \text {. }
$$

$2 \times 100=$ lbs. of skim-milk to be added to $1,000 \mathrm{lbs}$. of 30 per cent cream to reduce it to 25 per cent.

(c) Rule III. Multiply the number of pounds of cream to be diluted by the per cent of butter fat in the same and divide the product by the desired test. Find the difference between the quotient and the number of pounds of skim-milk to be added.

Problem: 1,000 lbs. of cream testing 30 per cent is to be reduced to 25 per cent by adding skim-milk. How many pounds of skim-milk must be added? -

\section{Solution:}

$$
30 \times 1,000
$$
25

1,200 , total pounds of cream, having the dessirerl trist.

$1,200-1,000=200 \mathrm{lbs}$. of skim-milk, to be added. 
47. When whole milk is used instead of skim-milk.

The following rule and problem will illustrate the methods employed when whole milk is used instead of skim-milk for diluting cream:

Rule III. Divide the difference between the test of the original cream and the desired test, by the difference between the desired test and the test of the milk to be used, and multiply the quotient by 100.

Problem: 1,000 lbs. of cream testing 30 per cent is to be reduced to 25 per cent by the addition of whole milk. How many pounds of milk testing 4 per cent must be added to give the desired test?

\section{Solution:}

$30-25=5 ; 25-4=21 ; 5 \div 21=.238$ lbs. of $4 \%$ milk to be added to every one lb. of $30 \%$ testing cream. To $1,000 \mathrm{lbs}$. $30 \%$ cream must be added $.238 \times 1.000=238 \mathrm{lbs} .4 \%$ testing milk.

\section{Standardizing whole milk.}

The principles involved in the foregoing problems may also be applied in standardizing milk, except cases where skim-milk or cream is to be extracted. A few problems will be sufficient to show the methods which can be employed.

The following rule may be employed when the milk is too low in per cent of butter fat and it is necessary to determine how many pounds of skimmilk must be extracted to produce the desired per cent of butter fat in the milk.

(a) Rule: Divide the per cent of butter fat in the milk by the per cent of butter fat desired; multiply the quotient by the original amount of milk and the 
result will be the number of pounds of milk testing the desired per cent. The difference between this result and the original amount of milk will be the quantity of skim-milk to be extracted.

Problem: 2,000 Ibs. of milk testing 3.5 per cent of butter fat is to be made to test 4 per cent. How many pounds of skim-milk must be extracted?

\section{Solution:}

$3.5 \div 4=875$.

$2,000 \times .875=1,750 \mathrm{lbs}$. of milk testing $4 \%$.

$2,000-1,750=250 \mathrm{lbs}$. of skimmilk to be extracted.

(b) When skim-milk is used to lower fat in milk.

When reducing the fat content in milk by adding skim-milk, the following rule may be used:

Rule: Multiply the milk by its per cent of butter fat, divide the product by the desired per cent of butter fat, multiply the quotient by 100 and the product will be the total amount of milk with the desired test. The difference between the original quantity and the total quantity will give the number of pounds of skim-milk to be added to produce the desired per cent of butter fat.

Problem: 5,000 lbs. of milk testing 4.5 per cent is to be reduced to 3.8 per cent butter fat. How many pounds of skim-milk must be added to reduce the test to 3.8 per cent of butter fat?

Solution:

$5,000 \times 4.5=225 \mathrm{lbs}$. fat in milk.

$225 \div 3.8=59.21$.

$59.21 \times 100=5,921$.

$5,921-5,000=921 \mathrm{lbs}$. of skim-millk to be added to $5,000 \mathrm{lbs}$. of $4.5 \%$ milk to reduce the test to $3.8 \%$. 
The following solution of this problem may also be used: $4.5 \div 3.8 \times 5,000=5,921$ lbs., the total amount of milk testing 3.8 per cent butter fat.

$5,921-5,000=921$, the whole amount of skim-milk added to reduce the test to $3.8 \%$.

These few problems will probably show that standardization is not too complicated to be made use of in every cream and milk plant, where milk or cream of different richness is mixed and in this manner the per cent of butter fat is raised or lowered. Its economical and commercial advantages can not be questioned; and since we are legally and morally bound not to take advantage of the public, its use seems to be indispensable. The simplicity with which the desired richness may be calculated is obvious.

49. How to use viscogen as a thickening agent.

Where viscogen is employed as a thickening agent, the following rule will help to simplify the work:

Rule: Multiply the amount of cream to be treated with viscogen by two-thirds of the number of cubic centimeters used to neutralize the acidity in one pound of cream. The product divided by 950 cubic centimeters (the number of c.c. in one quart) will equal the number of quarts of viscogen to be added to the cream to be treated.

Problem: If 6 cubic centimeters of viscogen will neutralize the acidity in one pound of cream, how many quarts of viscogen must be added to $800 \mathrm{lbs}$. of cream?

Solution: Six c. c. of viscogen will neutralize acidity in one pound of cream. 
$2 / 3$ of 6 c. c. $=4$ c. c. the quantity of viscogen to be added to one pound of cream.

800 lbs. $\times 4=3,200$, total number of cubic centimeters of viscogen to be added to $800 \mathrm{lbs}$. of cream.

$3,200 \mathrm{lbs} . \div 950=3.3$ plus, the number of quarts of viscogen to be added to cream.

50. A few suggestions on the use of viscogen in commercial cream.

The use of viscogen as a thickening agent has both advantages and disadvantages. Great care should be exercised in its use, which must always be regulated according to the condition of the cream. When too much is used, the cream has a disagreeable, disgusting flavor and aroma, and when such cream gets a little old, it is nothing short of rotten. There is no other defect in cream, whatever its source, which equals the rank flavor caused by too much viscogen. In practice it is well to use only one half the quantity necessary to neutralize the acidity of cream. When cream is very sweet, having an acidity of .1 per cent, it is well to add only $1 / 3$ of the quantity necessary to neutralize the acidity of the cream. The poorer the cream and the higher its acidity, the greater is the quantity of viscogen which may be added to it. When viscogen is properly used, it serves a very good purpose and where its use is allowed by law it is desirable to use it.

\section{(b) Butter fat values.}

51. Next to the values of standardization of milk and cream for city supply is the process of ascertaining the relative value of butter fat in milk when 
sold in the form of milk, eream and butter at retail prices, as compared with the wholesale butter fat value of milk.

In the following the cost of manufacture and the expenses incident to selling the product will not be considered, the aim being to point out the possible value of butter fat as sold in different products.

Crcam or milk is usually sold both by measure and weight. The weight of cream varies according to its fat content. Pure butter fat has a specific gravity of .9 against 1 , the specific gravity of water; consequently the richer the cream the lighter it is, and the thinner it is the heavier it is. Generally speaking the cream usually put upon the market weighs about $8.3 \mathrm{Ibs}$. per gallon. Cream containing from 18 to 22 per cent butter fat weighs a little more than this, while cream testing from 25 to 40 per cent weighs a little less per gallon. Milk does not vary in weight to any appreciable amount, therefore, no difference in weight of milk of different richness is made.

The explanation of a few problems is necessary in order to illustrate methods that may be used in determining the approximate amount of butter which ean be made from a given quantity of milk and the possible value of the butter fat when sold in the form of butter, cream and milk; these problems to be based upon an assumed retail price. Problems are also necessary to show the amount of butter fat in a quart or a gallon of cream of any richness and the price of cream according to the price of butter fat. 


\section{Problems with explanations.}

I. Find the quantity of butter which may be made from $5,000 \mathrm{lbs}$. of milk testing 4 per cent butter fat; also find the value of butter when the selling price is $22 \mathrm{c}$ a pound.

Rule: Multiply the amount of milk by its test, increase the product by $1 / 6$ of itself and multiply the sum by the price per pound.

\section{Solution:}

5,000 lbs. $\times .04=200$ lbs. butter fat.

200 lbs. $\times 1 / 6=331 / 3$ lbs. increase or overrun.

$200 \mathrm{lbs} .+331 / 3 \mathrm{lbs} .=2331 / 3 \mathrm{lbs}$. of butter made.

2331 / lbs. $\times 22 c=\$ 51.33$, value of butter.

Problem II. Find the value of the butter fat in 5,000 lbs. of 4 per cent milk when sold in the form of cream at the following prices: $20 \%$ cream at $20 \mathrm{c}$, $24 \%$ cream at $25 \mathrm{c}$ per quart and 30 per cent cream at $35 \mathrm{c}$ per quart. The weight of cream per gallon being as follows: $20 \%$ cream, about 8.4 lbs.; $24 \%$ cream, $8.3 \mathrm{lbs} ; 30 \%$ eream, $8.3 \mathrm{lbs}$.

Rule: Multiply test of cream by the weight per gallon and multiply the amount of milk by its test; divide the latter by the former and multiply the quotient by the price per gallon.

Solution (1). To find the value of milks when 20 per cent cream sells for $80 \mathrm{c}$ per gallon or $20 \mathrm{c}$ per quart:

$20 \% \times 8.4=168 \div 100=1.68 \mathrm{lbs}$. butter fat in 1 gallon of cream.

$5,000 \times .04=200 \mathrm{lbs}$. butter fat.

$200 \div 1.68 \times 100=119$ gallons of $20 \%$ cream.

$119 \times 80$ cents $=\$ 95.20$, value of 5,000 lbs. of milk. 
Solution (2). To find the value of the milk when 24 per cent cream is sold for 25c per quart or $\$ 1$ per gallon.

$24 \% \times 8.3=199.2$.

5,000 lbs. $\times .04=200$ lbs. butter fat in milk.

$199.2 \div 100=1.99$ plus lbs. butter fat in 1 gallon of cream.

$200 \div-1.99 \times 100=100.5$ gallons of $24 \%$ cream. $100.5 \times \$ 1.00=\$ 100.50$, value of $5,000 \mathrm{lbs}$. of milk.

Solution (3). To find the value of the milk when 30 per cent cream is sold for $35 \mathrm{c}$ per quart or $\$ 1.40$ per gallon.

$30 \% \times 8.3=249$.

$5,000 \times .04=-200 \mathrm{lbs}$. butter fat in milk.

$249 \div 100-2.49$ lbs. of fat in 1 gallon of cream.

$200 \div 100=80.4$ gallons of $30 \%$ cream.

$80.4 \times 1.40=\$ 112.56$, value of $5,000 \mathrm{lbs}$. of milk.

If $5,000 \mathrm{lbs}$. of $4 \%$ milk were sold in the form of milk we find the values to be as follows:

5,000 lbs. milk $\div 8.5$ lbs. (weight of 1 gallon) $=$ 588.2 gallons.

$588.2 \times 20$ cents $=\$ 117.64$, value of milk.

53 Comparative values.

When sold as butter at 22c per lb., value... \$ $\$ 1.33$ When sold as $20 \%$ cream at $80 \mathrm{c}$ per gallon,

value .................. 95.20

When sold as $24 \%$ cream at $\$ 1.00$ per gallon,

value ...................... 100.50

When sold as $30 \%$ cream at $\$ 1.40$ per gallon,

value ...................... 112.56

When sold as milk at 20e per gallon, value.. 117.64 
From the table it will readily be seen that milk when sold in th' form of milk has the highest market value. However, we must also consider that in marketing milk there are many expenses. There are losses in selling, and when the bottling system is used there is additional expense of this process, together with the loss from breakage of bottles, etc. The washing and sterilizing of the bottles is also an item which must not be overlooked. When cream is the main article sold in a city milk supply plant, and some buttor is malle, the buttermilk and skimmilk can in many cass's be clisposed of to great advantag". The skim-milk "an be male into cottage cheese and 1h' buttrmilk sold rither plain or creamed. There is sometimes quite a demand for creamed buttermilk, esperially during the summer months.

54. To find the value of a pound of butter fat when
cream sells at 25c per quart or $\$ 1$ per gallon proceed as follows: Multiply the test of the cream by the weight per gallon and divide the product by 100 . Divide the prien per gallon by this quotient and the result will be the price of $1 \mathrm{lb}$. of butter fat. $24 \times$ $8.3=1.99 \mathrm{lbs}$. fat in 1 gallon of $24 \%$ cream. $\$ 1.00-\div$ $1.99=50$ ( 


\section{INDEX TO CHAPTER IV.}

\section{PRORLEMS RELA'TING TO THE RECEIVING AND \\ SEPARATIYG OF MIIK.}

1'ar. No.

Page.

55. Find the amount of butter fat in milk........ 273

56. Find butter fat losses in skim milk......... 274

57. Find per cent of cream from milk.......... 275

58. Find per cent of cream from wilk when other fac-

tol's are known .................... 275

59. Find amount of cream from milk.......... 270

60. Find anount of cream when other factors are

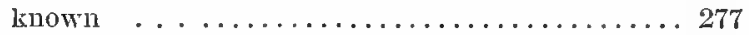

61. Find amount, of creanı, butter fat losses 11/4\%... 278

62. Find skim milk lbs. from any quaantity of milk.. 279

63. Find approximate test of cream........... 280

64. Find approximate average test of skim milk.... 281

65. Table of relative loss in skim milk.......... 282

66. Promiscuous problems ................. 283

B. Problems Pertaining to Cream Ripening.

67. Find lbs. of starter to add to cream..........285

68. Knowing per cent of starter added, find lbs...... 286

69. Find per cent of starter added to cream........286

70. Find acidity of cream after adding starter...... 288

71. Find acidity of cream before diluting......... 289

72. Promiscuous problems ................ 290

73. Problems bearing on the manufacture of butter... 291

74. Find per cent of fat in buttermilk.......... 292

75. Pounds of butter that can be made.......... 293

76. Find per cent of fat and moisture in butter.... 294

77. Promiscuous problems ................ 295 



\section{CHAPTER IV.}

\section{Problems Relating to the Receiving and Separating of Milk.}

55. To find the amount of butter fat in milk.

Problem: How many pounds of butter fat are there in 30,000 pounds of milk testing 4 per cent?

Rule. Multiply the number of pounds of milk by its test, and divide the result by 100 . This will give the number of pounds of butter fat in the milk.

Solution. $\quad 30,000 . \times 4=120,000 .: \quad 120,000 . \div 100=$ 1,200 . lbs.

Explanation: Every $100 \mathrm{lbs}$. of milk contains 4 per cent, .04 or $4 / 100$ of butter fat. When every hundred pounds of milk contains four pounds of butter fat, there will be as many pounds of butter fat in 30,000 lbs. of milk as 100 is contained in $(30,000 \times 4)$ or $1,200 \mathrm{lbs}$.

\section{Problems for Practice.}

(1.) How many pounds of butter fat in: 8,000 lbs. of milk testing $4 \%$ ?

Ans. 320 . lbs.

(2). $10,500 \mathrm{lbs}$. of mill testing $3.5 \%$ ?

Ans. 367.5 lbs.

(3). $18,750 \mathrm{lbs}$. of milk testing $3.9 \%$ ?

Ans. 731.25 lbs.

(4). 50,000 lbs. of milk testing $3.8 \%$ ?

Ans. $1,900 \mathrm{lbs}$.

(5). 100,000 lbs. of milk testing $4.1 \%$ ?

Ans. 4,100. lbs. 
56. To find butter fat losses in skim milk.

Problem: How much butter fat is lost in 25,000 lbs. of skim milk testing .09 per cent?

Rule: Multiply the skim milk pounds by its test, divide the result by 100 and point off as per rules 5 and 9.

Solution: $\quad 25,000 \times .09=2,250 ; \quad 2,250 \div-100=22.5$ lbs. Ans.

Explanation: Every $100 \mathrm{lbs}$. of skim milk contains .0009 or $9 / 10,000$ or .09 per cent butter fat. If every $100 \mathrm{lbs}$. skim milk contains .09 per cent butter fat, then 25,000 . lbs. will contain $25,000 \times .09 \%$ or 2,250.00. Dividing this by 100 gives the result, $22.50 \mathrm{lbs}$.

\section{Problems for Practice.}

How many pounds of butter fat are lost in:

1. 7,500 . lbs. of skim milk testing $.06 \%$ ? Ans. 4.5 lbs.

2. 10,500 . lbs. of skim milk testing $.09 \%$ ?

Ans. 9.45 lbs.

3. 25,780 . lbs. of skim milk testing $.15 \%$ ? Ans. 38.67 lbs.

4. 30,000 . lbs. of skim milk testing $.03 \%$ ? Ans. 9. lbs.

5. 30,000. lbs. of skim milk testing . $09 \%$ ? Ans. 27. lbs.

6. 30,000 . lbs. of skim milk testing .1\%? Ans. 30. lbs.

7. 30,000 . lbs. of skim milk testing .2\%? Ans. 60 . lbs.

8. 30,000 . lbs. of skim milk testing .3\%? Ans. 90. lbs. 


\section{To find the per cent of cream from milk.}

Problem: 5,000 lbs. of milk, delivered $800 \mathrm{lbs}$. of cream. Find the per cent of cream from milk.

Rule: Divide the total eream pounds by the total milk pounds, multiply the quotient by 100 ; the result is the per cent of eream from milk.

Solution $800 \div 5000=.16 \times 100=16 \%$. Ans.

or $800 \times 100 \div 5000=16 \%$. Ans.

or $800 / 5000$ reduced $=4 / 25$, expressed decimally $4 / 25==.16$ or $16 \%$.

Explanation: When 5,000 lbs. milk give $800 \mathrm{lbs}$. cream, $1 \mathrm{lb}$. of milk will give as many pounds as 5,000 is contained in 800 lbs. cream, which is .16 ; $100 \mathrm{lbs}$. milk will give $100 \times .16$ or $16 \mathrm{lbs}$. or $16 \%$. Ans.

\section{Problems for Practice.}

What is the per cent of cream from:

1. 8,780 lbs. milk delivering $900 \mathrm{lbs}$. cream? Ans. $10.25 \%$.

2. $10,300 \mathrm{lbs}$. milk delivering $1,275 \mathrm{lbs}$. cream? Ans. $11.69 \%$.

3. 20,785 lbs. milk delivering $3,750 \cdot \mathrm{lbs}$. cream? Ans. 13.23\%.

4. $35,000 \mathrm{lbs}$. milk delivering $7,000 \mathrm{lbs}$. cream? Ans. 20. \%.

5. 50,000 lbs. milk delivering $9,500 \mathrm{lbs}$. cream? Ans. $19 . \%$.

58. To find the per cent of cream from milk, when the amount of skim milk and cream separated are known. 
Problem: What is the per cent of cream from milk when a separator delivers $10 \mathrm{lbs}$. of cream to every 40 lbs. of skim milk?

Rule: Add the cream and skim milk separated at one time, together; divide the cream pounds by the sum, and multiply the quotient by 100 . The result will be the per cent of cream from milk.

Solution: $10+40=50 ; 10 \div 50=\%$ cream from 1 lb. mills.

Or $10+40=50 ; 10 \times 100 \div 50=20 \%$ cream from $100 \mathrm{lbs}$. of milk.

For every $50 \mathrm{lbs}$. of milk we get $10 \mathrm{lbs}$. of cream and we get as many pounds of cream for every pound of milk as 50 is contained in 10 , which is .2 , and from every $100 \mathrm{lbs}$. of milk we get $100 \times .2$ or $20 \mathrm{lbs}$. or $20 \%$.

\section{Problems for Practice.}

What is the per cent of cream from milk when a separator delivers:

1. $10 \mathrm{lbs}$. of cream and $35 \mathrm{lbs}$. of skim milk?

$$
\text { Ans. } 22+\% \text {. }
$$

2. $12 \mathrm{lbs}$. of cream and $60 \mathrm{lbs}$. of skim milk? Ans. $16+\%$.

3. $15 \mathrm{Ibs}$. of cream and $75 \mathrm{lbs}$. of skim milk? Ans. 17-\%.

4. $20 \mathrm{lbs}$. of cream and $88 \mathrm{lbs}$. of skim milk? Ans. $18+\%$.

5. $24 \mathrm{lbs}$. of eream and $95 \mathrm{lbs}$. of skim milk? Ans. $20+\%$.

59. To find the amount of cream of any desired test which milk of any richness can yield. 
Problem: How many pounds of 20 per cent testing cream will 800 lbs. of 4 per cent milk yield?

Rule: Divide the milk test by the cream test and multiply the quotient by 100 . Multiply this result by the number of pounds of milk; divide result by 100. The quotient is the number of pounds of cream.

Solution: $4 / 20=.2 ; .2 \times 100=20 ;$ or $4 / 20 \times 100=$ $20 \% ;(800 \times 20) \div 100=160$ lbs. Ans.

Milk lbs. Milk test. Cream test.

or $800+\overline{4}+20=160$ cream
lbs. Ans.

\section{Problems for Practice.}

How much cream can be obtained from the following:

Milk lbs. Milk test. Cream test.

$\begin{array}{rrrrrr}\text { 1. } & 255 & 4 \% & 20 \% & \text { Ans. } 51 . \text { lbs. } \\ \text { 2. } & 340 & 5 \% & 30 \% & \text { Ans. } 56.6 \mathrm{lbs} . \\ \text { 4. } 3,250 & 3.5 \% & 18 \% & \text { Ans. } 631.9 \mathrm{lbs} . \\ \text { 4. } 10,550 & 3.8 \% & 25 \% & \text { Ans. } 1,603.6 \mathrm{lbs} . \\ \text { 5. } 20,670 & 4.2 \% & 40 \% & \text { Ans. } 2,170.3 \mathrm{lbs} .\end{array}$

60. To find the amount of cream when the per cent of cream from milk, and the milk pounds are known.

Problem: The per cent of cream from $35,000 \mathrm{lbs}$. of 4 per cent milk is 22.5. Find the amount of cream.

Rule: Multiply the milk pounds by the per cent of cream from milk and divide the result by 100 . The quotient will be the cream pounds.

Solution: $\quad 25,000 \times 22.5=787,500 ; 787,500 \div 100=$ 7,875 ; or $(35,000 \div 100) \times 22.5=7,875$ lbs. Ans. 
Explanation: Every 100 lbs. of milk delivers 22.5 lbs. of "ream. Therefor", there are as many times 22.5 lbs. of eream delivered as 100 is contained in 35,000 , which is $350 ; 350 \times 22.5=7,875 \mathrm{lbs}$., the total amount of cream.

\section{Problems for Practice.}

Find the amount of cream when the per cent of cream from:

1. $5,507 \mathrm{lbs}$. of milk is $10.5 \%$ ? Ans. $578.23 \mathrm{lbs}$.

2. $10,780 \mathrm{lbs}$. of milk is 12.7 ?\% Ans. $1,369.06 \mathrm{lbs}$.

3. 15,872 lbs. of milk is $15.2 \%$ ? Ans. $2,412.54 \mathrm{lbs}$.

4. $20,975 \mathrm{lbs}$. of milk is $20.1 \%$ ? Ans. $4,215.9 \mathrm{lbs}$.

5. $40,4.35 \mathrm{lbs}$. of milk is $23.3 \%$ ? Ans. $9,421.35 \mathrm{lbs}$.

61. To find the approximate amount of cream, knowing the test of cream, and the amount and test of the whole milk. Skim milk losses are 11/4 per cent of the total fat in the milk.

Problem: What is the amount of cream received from $25,000 \mathrm{lbs}$. of milk testing 4 per cent, the cream testing 30 per cent and the butter milk losses being $11 / 4$ per cent of the fat in the milk?

Rule: I. Multiply the amount of milk by its test, and multiply this result by the per cent of loss.

II. From the total fat in the milk, subtract the loss, and divide the remainder by the cream test, multiply the quotient by 100 and the result will be the amount. of cream.

$$
\begin{aligned}
& 25,000 \times 4 \%=1,000 \mathrm{lbs} ; \quad 1,000 \times 1 \frac{1}{4} \%=12.50 \text { loss. } \\
& 1,000-12.50=987.5 ; \quad(987.5 \div 30) \times 100=3,291.66
\end{aligned}
$$

lbs. cream. Ans. 
Explanation: First find the amount of butter fat in the milk and from that subtract loss, which is 12.5; this leaves $987.5 \mathrm{lbs}$. butter fat in the cream. Each $100 \mathrm{lbs}$. of eream contains $30 \mathrm{lbs}$. butter fat, and there will be as many $100 \mathrm{lbs}$. of cream as 30 is contained in 987.5 , and the total cream will be 100 times this number, or $3,291.66 \mathrm{lbs}$. cream.

\section{Problems for Practice.}

Find the approximate amount of cream when losses incident to separating are in each case $11 / 4$ per cent of the total fat in milk.

Milk lbs. Milk test. Cream test. Cream lbs. Ans.

$\begin{array}{llll}\text { 1. } 12,760 & 4 \% & 25 \% & 2,016 \\ \text { 2. } 17,590 & 3.9 \% & 20 \% & 3,387 \\ \text { 3. } 25,300 & 3.8 \% & 18 \% & 5,211 \\ \text { 4. } 50,000 & 4.1 \% & 35 \% & 5,784 \\ \text { 5. } 50,000 & 4.1 \% & 50 \% & 4,048\end{array}$

62. To find amount of skim milk from any quantity of milk.

Problem: A creamery receives 24,000 lbs, of whole milk; 80 lbs. of skim milk out of every 100 lbs. of milk are returned to patrons. How much skim milk does the creamery return to patrons?

Rule: Multiply milk pounds by per cent of skim milk returned and divide result by 100 . The quotient is number of skim milk pounds.

Solution: $24,000 \times 80=1,920,000 ; 1,920,000 \div 100=$ 19,200 lbs. Ans.

Explanation: For every 100 lbs. of whole milk delivered the patron gets $80 \mathrm{lbs}$. of skim milk. The total skim milk will be $(24,000 \times 80) \div 100=19,200$ lbs. 


\section{Problems for Practice.}

Find amount of skim milk returned to patrons when :

Milk received

1. $10,000 \mathrm{lbs}$.

2. $15,780 \mathrm{lbs}$.

3. 20,340 lbs.

4. $50,590 \mathrm{lbs}$.

5. $50,590 \mathrm{lbs}$.
Skim milk returned

$80 \%$

$85 \%$

$90 \%$

$75 \%$

$80 \%$
Pounds returned 8,000 lbs. 13,413 lbs. $18,306 \mathrm{lbs}$. 37,942 lbs. 40,482 lbs.

63. To find the approximate test of cream, knowing the amount and test of milk, the pounds of cream separated, and allowing 11/4 per cent mechanical loss on the total butter fat.

Problem: $45,000 \mathrm{lbs}$. of milk testing 4 per cent gave 3,500 lbs. of cream. Find the test of cream.

Rule: Find the total butter fat in milk and multiply this by the per cent of loss. Subtract the loss from the total butter fat and divide the remainder by the number of pounds of cream. Multiply the quotient by 100 and the result will be the test of the cream.

Solution: $\quad 45,000 \times 4 \% \div-100=1,800 ;(1,800 \times 11 / 4)$ $\times 100=22.5 ; \quad 1,800-22.5=1,777.5 ; \quad(1,777.5 \div 3,500)$ $\times 100=50.6 \%$. Ans.

Explanation: From the total butter fat in the milk we subtract the loss. Then we divide the remaining butter fat by the total amount of cream. This gives the butter fat in one pound of cream, and $100 \mathrm{lbs}$. of cream will test 100 times the butter fat in one pound of eream, or 50.8 per cent. 


\section{Problems for Practice.}

Find the test of cream when:

Cream

Separated. Milk lbs.

1. $350 \mathrm{lbs}$.

2. $1,500 \mathrm{lbs}$.

3. $2,800 \mathrm{lbs}$.

4. $5,550 \mathrm{lbs}$.

5. $5,550 \mathrm{lbs}$.
4,000

9,500

20,780

45,000

45,000
Milk test.

Cream test.

Ans.

$4 \%$

$3.9 \%$

$4 \%$

$3.8 \%$

$3.9 \%$
$45.1 \%$

$24.3 \%$

$29.3 \%$

$30.4 \%$

$31.2 \%$

64. To find the approximate average test of skim milk, knowing the total butter fat in milk and in cream separated, and knowing the number of pounds of skim milk.

Problem Milk contained 2,540 lbs. butter fat, and the cream contained 2,500. Ibs. butter fat. There were 56,108. 1bs. skim milk. Find the test of skim milk.

Rule Divide the difference in the amount of butter fat in milk and cream by the skim milk pounds, and multiply quotient by 100 . The result is the the test of the skim milk.

Solution: $\quad 2,540-2,500=40 ;(40 \div 56,108) \times 100=$ $.071 \%$. Ans.

Explanation: First find the difference, which is 40 lbs. Then by dividing this by the number of pounds of skim milk, and multiplying by 100 , we get the test per hundred pounds or in per cent. 


\section{Problems for Practice.}

Find the test of skim milk in the following:

Fat in milk. Fat in cream. Lbs. skim milk. Ans.

1. 295. Ibs.

290. lbs.

3,120 .

$.16 \%$

2. 900 . lbs.

892. lbs.

3. 3,250 . lbs.

3,225 . lbs.

17,460 .

$.046 \%$

4. 5,675. lbs.

5,520 . lbs.

39,812 .

$.062 \%$

5. 5,675. lbs.

5,440 . lbs.

133,440 .

$.11 \%$

133,440 .

$.17 \%$

65. Table showing relative loss in skim milk at 25c per lb. of butter fat. Average skim milk test .05 to .03 per cent.

T'able Shouring Relative Loss in slcimming at 25 cents per lb. of Butter Fat. Average slitm Milk Tests .05 to $3 \%$.

\begin{tabular}{c|c|c|c}
\hline $\begin{array}{c}\text { Skim milk lbs. } \\
\text { Daily }\end{array}$ & $\begin{array}{c}\text { Test } \\
\%\end{array}$ & $\begin{array}{c}\text { IJoss } \\
\text { in lbe. }\end{array}$ & $\begin{array}{c}\text { At 25e per } \\
\text { 1b. daily }\end{array}$ \\
\hline 10,000 & $.05 \%$ & 5. & $\$ 1.25$ \\
\hline 10,000 & $.08 \%$ & 8. & 2.00 \\
\hline 10,000 & $.10 \%$ & 10. & 2.50 \\
\hline 10,000 & $.13 \%$ & 13. & 3.25 \\
\hline 10,000 & $.15 \%$ & 15. & 3.75 \\
\hline 10,000 & $.18 \%$ & 18. & 4.50 \\
\hline 10,000 & $.20 \%$ & 20. & 5.00 \\
\hline 10,000 & $.23 \%$ & 23. & 5.75 \\
\hline 10,000 & $.25 \%$ & 25. & 6.2 .7 \\
\hline 10,000 & $.28 \%$ & 28. & 7.00 \\
\hline 10,000 & $.30 \%$ & 30. & 7.50 \\
\hline
\end{tabular}

The above table should serve to bring out more clearly the fact that in creamery work, not unlike brokerage, it is the fractional parts which are very 
important and essential factors in making for the success or failure of the business.

The same comparative losses occur in buttermilk, therefore, it is just as important to churn so as to reduce buttermilk fiat losses to the minimum.

\section{Promiscuous problems.}

1. A creamery receives $2,480 \mathrm{lbs}$. of milk testing 4.2 per cent. The skim milk is 80 per cent of the whole and tests 1 per cent fat. What is the (a) per cent of cream taken, and (b) the test of the cream? Ans. (a) 20 per cent; (b) 22.6 per cent.

2. A creamery receives $30,000 \mathrm{lbs}$ of milk testing 3.7 per cent, of which 85 per cent is skim milk testing .08 per cent. Find (a) the fat lost in skim milk, (b) test of cream, (c) per cent of cream from milk, (d) total weight of cream. Ans. (a) $20.4 \mathrm{lbs}$; (b) 24.21 per cent; (c) 15 per cent; (d) 4,500 lbs.

3. At a creamery 80 per cent of the milk is skim milk, testing .05 per cent, and is returned to the patrons. The total skim milk is $2,880 \mathrm{lbs}$. Find the (a) total number of pounds of milk received, and (b) the total fat lost in the skim milk. Ans. (a) 3,600 lbs.; (b) 1.44 lbs.

4. Cream tests 20 per cent butter fat and the total milk, which is $35,000 \mathrm{lbs}$, tests 4 per cent. Find (a) the per cent of cream taken from the milk, and (b) the total weight of cream, allowing a loss of 1 per cent butter fat in skimming. Ans. (a) 19.8 per cent; (b) 6,930 lbs.

5. Cream tests 30 per cent, the total weight is 2,250 lbs.; $10 \mathrm{lbs}$. of fat were lost in skimming. Find (a) the per cent of loss in skimming on the total but- 
ter fat in milk, (b) the number of pounds of milk which tests 4 per cent, and (c) the per cent of eream from milk. Ans. (a) 1.5 per cent; (b) 17,125 lbs.; (c) 13.2 -per cent.

6. A gathered ream plant receives $5,000 \mathrm{lbs}$. of. cream daily, testing 32 per cent butter fat, and makes $1,850 \mathrm{lbs}$. butter. To the cream is added 800 lbs. of skim milk starter. The buttermilk tests .2 per cent. Find (a) loss of fat in buttermilk, (b) per cent of buttermilk from cream, (c) per cent of loss of butter fat on total fat in cream. Ans. (a) 7.9 lbs.; (b) $68+$ per cent; (c) .49 per cent.

7. What will be the (a) test of cream, (b) per cent of cream from milk, and (c) test of skim milk when 50,000 lbs. of 4 por cent milk are received and the skim milk is 85 per cent of the whole; allowing a loss of 20 los. of butter fat in the skim milk. Ans. (a) 26.4 per cent; (b) 15 per cent; (c) .047 per cent.

8. A creamery in good running order loses $1 \frac{1}{2}$ per cent of the total fat in milk. When separating is carelessly done a creamery may lose $31 / 2$ per cent of the total fat in milk. When a creamery received $100,000 \mathrm{lbs}$. of milk per day testing 4 per cent and the cream is 12 per cent of the milk, find (a) the difference in the test of the cream, and (b) the difference in loss when butter fat sells at 30 cents per pound.

Ans. (a) When loss is $3 \frac{1}{2}$ per cent instead of $1 \frac{1}{2}$ per cent, cream tests .67 per cent less.

Ans. (b) When loss is $31 / 2$ per cent instead of $1 \frac{1}{2}$ per cent, loss at $30 \mathrm{c}$ per $\mathrm{lb}$. is $\$ 24.00$ per day. 


\section{B. Problems Pertaining to Cream Ripening.}

67. To find how many pounds of starter should be added to cream of any richness to reduce it to any desired per cent of butter fat, assuming that a skim milk starter is used.

Problem: How many pounds of starter will it require to reduce $3,000 \mathrm{lbs}$. of 30 per cent cream to 25 per cent cream?

Rule. I. Multiply the cream pounds to be reduced by its test and divide the result by 100 . The result will be the total fat in the richer cream.

II. Divide the total butter fat by the desired test of cream and multiply the quotient by 100. From this result subtract the cream pounds to be diluted. The difference will be the amount of starter to be added.

Solution: $3,000 \times 30 \div 100=900$. lbs. butter fat; $(900 \div 25) \times 100=3,600-3,000=600$ lbs. Ans.

Explanation: By subtracting 25 from 30, we get 5 which is $1 / 5$ of the test of the desired cream. The same relation exists between the amount of cream to be diluted and the amount of starter necessary to dilute it. Therefore, it must be increased by $1 / 5$ of itself, or 600 lbs. of a skim milk starter.

\section{Problems for Practice.}

Find the amount of starter to be added to:

Cream Ibs. Cream test. Reduced to. Ans.

1. $3,275 \mathrm{lbs}$.

$30 \%$

$25 \%$

$675 \mathrm{lbs}$.

2. $4,560 \mathrm{lbs}$.

$40 \%$

$30 \%$

$1,520 \mathrm{lbs}$.

3. $6,780 \mathrm{lbs}$.

$50 \%$

$35 \%$

2,905 lbs.

4. $10,500 \mathrm{lbs}$.

$30 \%$

$25 \%$

$2,100 \mathrm{lbs}$.

5. $10,500 \mathrm{lbs}$.

$30 \%$

$20 \%$

5,250 lbs. 
68. To find the number of pounds of starter to be added to cream, when the per cent of starter is known.

Problem: 20\% of starter is to be added to 3,080 lbs. of cream. Ilow many pounds of starter will it require:

Rule: Multiply the eream pounds by the per cent of starter and divide the result by 100 . The quotient will be the numbrr of pounds of starter required.

Solution: $\quad 3,080 \times 20=61,600 ; \quad 61,600 \div 100=616$. Ans.

Explanation: By adding 20 per.eent of starter we add 20 lbs. to every hundred pounds of cream. Therefore we must add as many times $20 \mathrm{lbs}$. as there are hundreds in the amount of cream $(3,080)$, or $616 \mathrm{lbs}$.

\section{Problems for Practice.}

How many pounds of starter are required when:

1. $10 \%$ of starter is to be added to $2,570 \mathrm{lbs}$. cream. Answer, 257 lbs.

2. $15 \%$ of starter is to be added to $3,800 \mathrm{lbs}$. cream. Answer, $570 \mathrm{lbs}$.

3. $25 \%$ of starter is to be added to $4,800 \mathrm{Ibs}$. cream. Answer, 1,200 lbs.

4. $30 \%$ of starter is to be added to $5,780 \mathrm{lbs}$. cream. Answer, 1,734 lbs.

5. $50 \%$ of starter is to be added to $8,500 \mathrm{lbs}$. cream. Answer, 4,250 lbs.

69. To find the per cent of starter added when any quantity of starter was added to any quantity of cream. 
Problem: 670 lbs. starter were added to cream, making a total of $3.200 \mathrm{lbs}$. of cream. What per cent of starter was added?

Rule: From the number of pounds of cream subtract the number of pounds of starter, divide the difference into the number of pounds of starter; multiply the quotient by 100 and the result is the per cent of starter.

Solution: $3,200--670-2,530 ;(670 \div 2,530) \times 100=$ $26.5 \%$. Ans.

Explanation: When any amount of starter has been added to cream we first subtract the number of pounds of starter from the total number of pounds given. This gives the number of pounds of cream before the starter was added. By dividing the number of pounds of cream into the number of pounds of starter and multiplying by 100 we get the per cent of starter.

What is the per cent of starter when:

1. $1,600 \mathrm{lbs}$. of cream contain $300 \mathrm{lbs}$. of starter? Ans. $23.07 \%$.

2. 4,000 lbs. of cream contain $600 \mathrm{lbs}$. of starter? Ans. $17.6 \%$.

3. $4,500 \mathrm{lbs}$. of cream contain $800 \mathrm{lbs}$. of starter? Ans. $21.6 \%$.

4. 30,000 lbs. of cream contain 6,000 lbs. of starter? Ans. 25\%.

5. $30,000 \mathrm{lbs}$. of cream contain $7,600 \mathrm{lbs}$. of starter? Ans. 33.4\%. 
70. Knowing the acidity of both cream and starter find the acidity after starter is added to cream.

Problem: The acidity of the starter is $.70 \%$; the acidity of the cream (100 lbs.) is $.22 \%$. $30 \%$ (or 30 lbs.) of starter is added to every $100 \mathrm{lbs}$. of cream. Find acidity of cream after starter is added.

Rule: To the acidity in the cream add the acidity in the per cent of starter ( 30 lbs.) to be added, and divide the sum by $100+$ the per cent to be added. Multiply the quotient by 100 and the result will be the acidity of cream after starter is added.

Solution: $\quad(70 \times 30) \div-100=.21 ; .21+.22=.43$; $.43 \div 130=.0033 ; .0033 \times 100=.33 \%$. Ans.

Explanation: 100 lbs. cream tests $.22 \%$ acidity. $100 \mathrm{lbs}$. starter tests $.70 \%$. We add $30 \%$ or $30 \mathrm{lbs}$. . of starter to each $100 \mathrm{lbs}$. of cream. We have .22\% acidity in each $100 \mathrm{lbs}$. cream. We have $30 \mathrm{lbs}$. of starter at $.70 \%$ acidity $=.21$ acidity. The total acidity is .43. The total cream and starter is $130 \mathrm{lbs}$. and the total acidity of eream and starter is .43 ; $.43 \div 130=.0033 . .0033 \times 100=.33 \%$, the acidity of $100 \mathrm{lbs}$. of cream after the starter is added.

\section{Problems for Practice.}

Find acidity of cream when the per cent of starter to be added is:

$\begin{array}{cccc}\text { Starter. } & \text { Acidity. } & \text { Cream Acidity. } & \text { Ans. } \\ 10 \% & .65 \% & .25 \% & .286 \% \\ 15 \% & .75 \% & .20 \% & .27 \% \\ 20 \% & .60 \% & .23 \% & .29 \% \\ 25 \% & .68 \% & .20 \% & .296 \% \\ 30 \% & .70 \% & .26 \% & .361 \%\end{array}$




\section{To find acidity of cream when sweet milk or water is used to reduce acidity.}

Problem: What will be the acidity of eream having $.65 \%$ acidity, when (a) $12 \%$ of water is added; (b) when $12 \%$ of milk with an acidity of $.15 \%$ is added?

Rule I. Divide the per cent of acidity in cream to be diluted, by $100+$ the per cent of water to be added. Multiply the quotient by 100 , and the result will be the per cent of acidity after diluting.

Rule II. Multiply the per cent of milk to be added by its acidity. 'To this add the acidity in per cent in the cream to be diluted; divide the sum by 100 t the per cent of milk to be added and multiply the quotient by 100 . The result is the acidity of the diluted cream.

Solution: (a) $.65 \div(100+12)=.0058 ; .0058 \times 100$ $=.58 \%$. Ans. (b) $.65+(12 \times .15)=.668 ; .668 \div 112=$ $.0059 ; .0059 \times 100=.59 \%$. Ans.

Explanation: It will be seen that when we add $12 \%$ we add $12 \mathrm{lbs}$. to each $100 \mathrm{lbs}$. of cream. This makes $112 \mathrm{lbs}$. of cream. When the addition is water, 112 lbs. of the cream contains $.65 \%$ acid and $100 \mathrm{lbs}$. of the cream will test as many per cent as 112 is contained in $.65 \%$. This quotient multiplied by 100 equals $.58 \%$. When we add milk which has some acidity, we must first find out how much acidity is added to the cream. This we find by multiplying the amount added by its test. We add the test of acidity of the cream and the acidity in the milk, 
which in this case is $.018+.65$, which equals .668 . This is the acidity of $112 \mathrm{lbs}$. of diluted cream. To find the per cent of acidity we divide .668 by 112 which gives us .0059 . $.0059 \times 100=.59 \%$. Ans.

\section{Problems for Practice.}

Find the per cent of acidity in cream when:

1. $10 \%$ water is added to cream having $.75 \%$ acid. Ans. (a) $.68+\%$, (b) $.69 \%$.

2. $15 \%$ water is added to cream having $.80 \%$ acid. Ans. (a) $.695 \%$, (b) $.715 \%$.

3. $20 \%$ water is added to cream having $.75 \%$ acid. Ans. (a) $.625 \%$, (b) $.65 \%$.

4. $10 \%$ water is added to cream having $.65 \%$ acid. Ans. (a) $.59 \%$, (b) $.60 \%$.

5. $15 \%$ water is added to cream having $.65 \%$ acid. Ans. (a) $.56 \%$, (b) $.58 \%$.

When milk with an acidity of $.15 \%$ was used instead of water in the above problems the answers marked $\mathrm{b}$ show the result.

\section{Promiscuous problems.}

1. A ereamery receives daily $1,500 \mathrm{lbs}$. of cream testing $38 \%$ butter fat. The test is to be reduced to $30 \%$ by adding a skim milk starter. (a) How many pounds of starter must be added? (b) What per cent of starter is added? Ans. (a) 400 lbs., (b) $262 / 3 \%$.

2. The average test of $20,000 \mathrm{lbs}$. of hand separator cream is $30 \%$. After adding all the rinsings the test is $291 / 2 \%$. The test for churning should be 
$25 \%$. Find (a) the amount of rinse water added; (b) amount of starter required for redueing test to 25\%. Ans. (a) 339 lbs.; (b) 3,661 lbs.

3. The manager of a creamery notified the butter maker that all cream should have not more than $.5 \%$ acidity at the time of churning. A lot of cream, on arrival at the creamery had an average acidity of $.62 \%$ and tested $40 \%$ butter fat. Water was to be used as a diluent. Find amount of water necessary to reduce the acidity of (a) $2,200 \mathrm{lbs}$. of cream; (b) $2,000 \mathrm{lbs}$. of cream to $.5 \%$ acidity. Ans. (a) 528 lbs.; (b) 480 lbs.

4. $1,200 \mathrm{lbs}$. of $40 \%$ testing eream tested $25 \%$ after the starter was added. Find (a) amount and (b) per cent of starter. Ans. (a) $720 \mathrm{lbs}$; (b) $60 \%$.

5. A creamery receives $50,000 \mathrm{lbs}$. of $4 \%$ milk and $20,000 \mathrm{lbs}$. of $35 \%$ cream. $2 \%$ of the fat in the mills was lost in skimming. After mixing the eream separated from milk with cream received the test was $37 \%$ fat. Find amount of cream separated and amount of starter necessary to reduce the test of the cream to $32 \%$ fat. Ans. Separated cream, 4,216 lbs.; starter necessary, 8,000 lbs.

73. Problems bearing on the manufacture of butter. To find the amount of butter fat lost in buttermilk, when the number of pounds of cream and butter are known.

Problem: 980 lbs. of butter were made from 3,200 Ibs. of cream; buttermilk tested .2 per cent. What was the loss in butter fat? 
Rule: From pounds of cream subtract pounds of butter made; multiply remainder by buttermilk test and divide produet by 100 . The quotient will be pounds butter fat lost.

Solution: $3,200-980=2,220$ lbs. buttermilk; (2,$220 \times .20) \div 100=4.44$ lbs. butter fat lost.

Explanation: Aside from the water used for rinsing cream utensils, the difference between the amount of cream churned and butter made will give the pounds of buttermilk. This multiplied by the test and divided by 100 will equal pounds of butter fat lost.

\section{Problems for Practice.}

Find pounds of butter fat lost.

$$
\text { Butter lbs. Cream lbs. B. M.test. Ans. }
$$

1. $995 \mathrm{lbs}$.

3,500 lbs.

$.20 \%$

5. +libs.

2. $2,550 \mathrm{lbs}$.

9,670 lbs.

$.15 \%$

$10.6 \mathrm{lbs}$.

3. $8,700 \mathrm{lbs}$. 20,675 lbs.

$.10 \%$

$11.9 \mathrm{lbs}$.

4. $9,250 \mathrm{lbs}$.

25,456 lbs.

$.05 \%$

$8.1 \mathrm{lbs}$.

5. $9,250 \mathrm{lbs}$.

25,456 lbs.

$.15 \%$

24.2 lbs.

74. To find the per cent of fat in buttermilk when the pounds of cream, its test, the per cent of fat in butter and the number of pounds of butter are given.

Problem: 3,540 lbs. of $30 \%$ cream made 1,290 lbs. butter with a fat content of $82 \%$. What is the test of the buttermilk?

Rule I. Multiply the number of pounds of cream by its test and from the result subtract the result obtaines by multiplying the pounds of butter by the per cent of fat it contains. 
Rule II. Subtract the number of pounds of butter from the number of pounds of eream and divide this result into the difference between the fat in the cream and the butter. Multiply the quotient by 100 and the result will be the test of buttermilk.

Solution: $3540 \times 30=1,062$; butter fat in cream. $1,290 \times 82=1,057.8$ butter fat in butter. 1,062$1,057.8=4.2 ; 4.2 \div(3,540-1,290) \times 100=.18 \%$.

Explanation: First find the number of pounds of butter fat in the cream and in the butter made from it. These are 1,062 and 1,057.8 lbs. respectively. Now subtract the total butter made, from the total cream pounds, and the difference, which is $2,250 \mathrm{lbs}$, is the buttermilk. Now divide the fat loss- $4.2 \mathrm{lbs}$. by 2,250 (the buttermilk) and the result is the test of the buttermilk, .18\%. Ans.

75. To find the number of pounds of butter, with a given per cent of fat, which can be made from a given number of pounds of butter fat in cream, allowing a loss of a certain per cent of fat in the buttermilk.

Problem: How many pounds of butter, having $82.5 \%$ fat, can be made from $4,560 \mathrm{lbs}$. of $32 \%$ cream, the loss in buttermilk being $.75 \%$ of the total fat in cream?

Rule: Multiply cream pounds by the test of cream; divide the result by 100 . This gives total cream fat. Multiply this by the per cent of loss; divide result by 100. This gives loss of fat. Divide the difference between loss and total fat in cream by the per cent of fat in butter; multiply quotient 
by 100. Result is number of pounds of butter which "aln be made.

Solution: $\quad(4,560 \times 32) \div 100=1,459.2 ; \quad(1,459.2 \times$ $.75) \div 100=10.94 ; \quad 1,459.2-10.94=1,448.26$; $\quad(1,448$.$26 \div 82.5) \times 100=1,755.4$ lbs. Ans.

\section{Problems for Practice.}

Find the number of pounds of butter which ean be made, allowing a loss of .4 per cent of total fat in cream.

\section{Test of Fat in}

Cream lbs, cream. butter, Butter lbs.

$\begin{array}{llllll}\text { 1. } & 2,240 \mathrm{lbs} . & 30 \% & 80 \% & \text { Ans. } 836.65 \mathrm{lbs} . \\ \text { 2. } & 3,250 \mathrm{lbs} . & 25 \% & 83 \% & \text { Ans. } 976.7 \mathrm{lbs} . \\ \text { 3. } & 3,250 \mathrm{lbs} . & 25 \% & 80 \% & \text { Ans. } 1011 . \mathrm{lbs} . \\ \text { 4. } & 5,600 \mathrm{lbs} . & 30 \% & 82 \% & \text { Ans. } 2040.5 \mathrm{lbs} . \\ \text { 5. } & 5,600 \mathrm{lbs} . & 30 \% & 81 \% & \text { Ans. } 2065.7 \mathrm{lbs} .\end{array}$

76. To find the approximate per cent of fat and moisture in butter when the fat in cream and butter are known; $3 \frac{1}{2} \%$ being allowed for salt and casein.

Problem: Cream contains 800 lbs. of butter fat and made $970 \mathrm{lbs}$. of butter. What is the approximate per cent of fat and of moisture in the butter?

Rule I. Divide the fat pounds by the butter pounds; multiply the quotirnt by 100 . The result is the per cent of fat in the butter.

Rule II. To the per cent of fat in the butter add $3 \% \%$; subtract this sum from 100 ; the remainder is the approximate per cent of moisture in the butter.

Solution: $(800 \div 970) \times 100=82.47 \%$ fat in butter. $82.47+3.5=85.97 ; 100-85.97=14.03 \%$ moisture. 
Explanation: When $800 \mathrm{lbs}$. of fat are made into $970 \mathrm{lbs}$. of butter we have $800 / 970$ of $100 \mathrm{lbs}$. fat in every $100 \mathrm{lbs}$. of butter. The moisture must equal the difference between fat in butter plus $3 \frac{1}{2}$ and 100 .

\section{Problems for Practice.}

Find the per cent of fat and moisture in butter in the following:

Fut in cream Butter. Fat in butter. Moisture.

1. $850 \mathrm{lbs}$. 1,000 lbs. Ans. 85 . $\% 11.5 \%$

2. $1,500 \mathrm{lbs}$. 1,850 lbs. Ans. $81.08 \%$ 15.42\%

3. 2,180 lbs. 2,560 lbs. Ans. $85.15 \%$ 11.35\%

4. 3,670 lbs. 4,500 lbs. Ans. $81.55 \% \quad 14.95 \%$

5. 10,500 lbs. $12,500 \mathrm{lbs}$. Ans. $84 . \% 12.5 \%$

\section{Promiscuous problems.}

1. A creamery receives $20,000 \mathrm{lbs}$. of $4 \%$ milk daily; losses in separating are $11 / 2 \%$ of the total fat; losses in the buttermilk are $1 / 2 \%$ of the total fat. How many pounds of butter with $80,81,82$ or $83 \%$ fat ean be made from the milk? $80 \%=985 \mathrm{lbs}$., $81 \%$ $=972.7 \mathrm{lbs} ., 82 \%=960.9 \mathrm{lbs} ., 83 \%=94.9 \mathrm{lbs}$. Ans.

2. (a) The total milk received is $15,000 \mathrm{lbs}$. testing $4 \%$; from this milk was made $720 \mathrm{lbs}$. of butter with $80 \%$ fat. Find the loss of butter fat in pounds and in per cent.

(b) What is the test of the skim milk and buttermilk when skim milk is $80 \%$ of the whole milk, and the buttermilk is $75 \%$ of the cream? $2 / 3$ of total fat lost was lost in skim milk and $1 / 3$ was lost in buttermilk. Ans. to (a): Butter fat. lost 24 lbs.; butter fat lost $4 \%$. Ans. to (b): Skim milk test $.13 \%$; buttermilk test $.35 \%$. 
tions, each shipping $5,000 \mathrm{Ibs}$. of $30 \%$ cream, according to their test. When cream was tested at the creamery it was found that three stations were $2 \%$ short of total butter fat in their cream and two stations were $3 \%$ short. (a) What is average test of cream at creamery? (b) How many pounds of butter fat is Iost. Ans. (a) 29.28; (b) $180 \mathrm{lbs}$.

(b) Suppose the butter made from fat in above cream contained $83 \%$ fat, (a) how many more pounds of butter could be made from it if it contained $81 \%$ fat; (b) what would be the gain in pounds of butter in one year of 300 . days, (c) and the value at $30 \mathrm{c}$ per pound? Ans. to (b) : a-208 lbs., b-62,400 lbs., c-\$18,720. 


\section{INDEX TO CHAPTER V. \\ DISCUSSING COMPARATIVE READING OF CREAM TEST BOTTLES.}

Par. No.

Page.

78. Basis of comparison .................. 299

79. Comparing the reading of $30 \%$ bottle........ 299

80. Comparing a 9 gram cream bottle........... 301

81. Comparing a $55 \%-18$ gram bottle.......... 302

82. Comparing a $50 \%$ 6-inch cream bottle........ 304

83. Comparing a $30 \%$ cream bottle............ 305

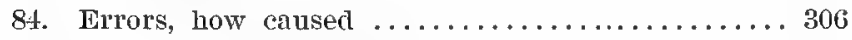

85. Comparative graduation of bottles.......... 306

86. Reading of cream tests............... 307

87. How to read cream tests........................ 308

88. Most accurate cream bottles............. 309 



\section{CHAPTER V.}

\section{Discussing Comparative Reading of Cream Test Bottles.}

Note-For convenience in illustrating the per cent on the graduation is numbered from top down, instead of the usual way, from the bottom up.

78. Basis of comparison. Assuming that the reading of the actual fat column of any cream test bottle is .2 per cent lower than the actual per cent of fat in cream, due to 2 per cent of fat remaining in the bulb of the bottle; we will take the method of reading the milk test bottle as a standard for comparison. The average creameryman reads the tests at about $130^{\circ} \mathrm{F}$. The meniscus is about .2 per cent on the reading of the test, which is equal to the .2 per cent of fat left in the bulb of the test bottle.

79. Comparing the Reading of 30 per cent, 9 in. cream bottle with a milk test bottle. Fig. I. The average depth of the meniscus of the 30 per cent 9 in. cream test bottle, Fig. II, is between .4-.5 per cent. Reading this bottle to the extreme top of the fat column, the reading will be from .2 to .3 per cent too high. The curvature of the bottom of the fat column is greater than the curvature of the fat column in the mills test bottle, Fig. I.

By reading the fat column in the cream test bottle, Fig. II., from the extreme bottom to the extreme top, the reading will be about 4 per cent too high. According to the variation in the eveness of the bot- 
tom curve, c, the reading should be done from the extreme bottom line, $\mathrm{d}$, to almost the extreme bottom of meniscus, b. Read from $d$ to $f$.
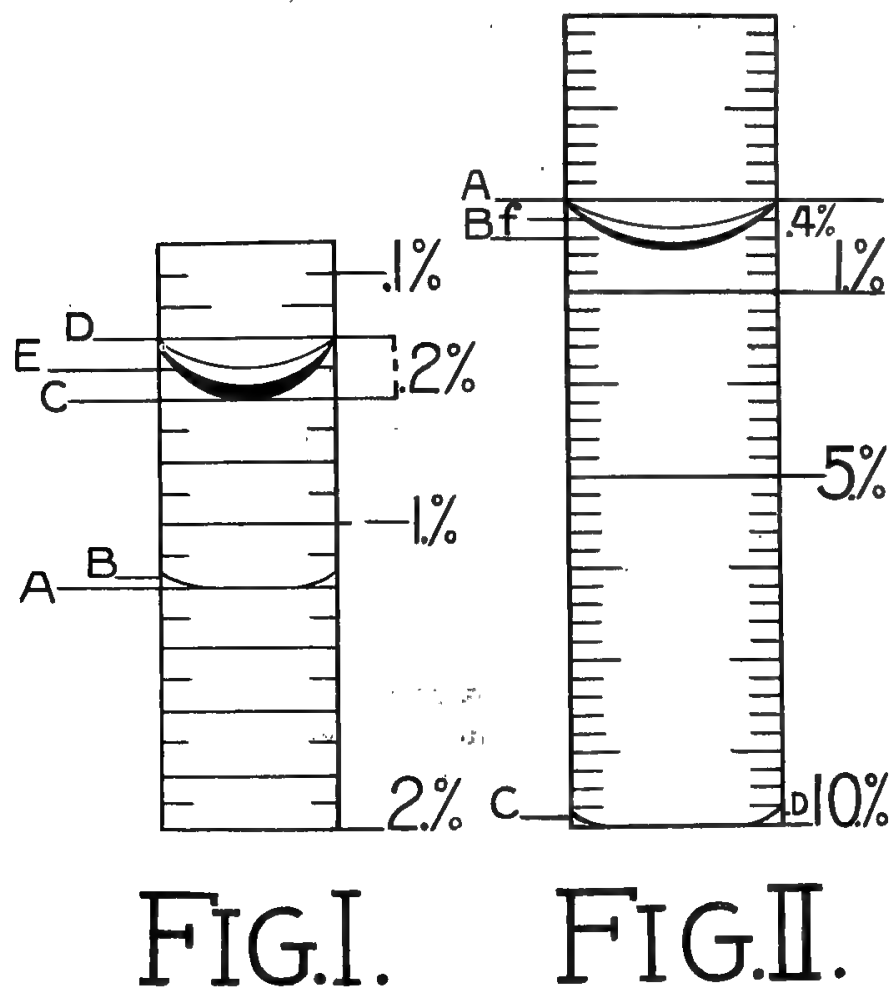

NOTE.-Figs. II, III, IV, V and VI are part of neck of cream bottle enlarged two times.

In reading from $\mathbf{d}$ to $f$, the upper part of the meniscus is cut off to allow the fat making up the sides of the meniscus to fill up the hollowness below line $\mathbf{f}$. The 2 per cent of fat left in the bottle will displace 
the curvature at the bottom of the fat column--d, c. The meniscus oceupies .4 per cent on the reading. This bottle, due to the small size of the meniscus, is the best bottle for the inexperienced creameryman. Even if the dividers should slip a little, the error arising from this would not be great, because the graduation is in .2 per cent, and 1 per cent on the graduation takes up quite a space on the bottle. By weighing out 9 grams into bottle shown in Fig. III. an error made is increased by two, and when an error is made in reading the test of the sample the error made in weighing is multiplied by 4 .

80. Comparing a. 9 gram Fig.' IV., 50 per cent cream test bottle with an 18 gram, 30 per cent cream test bottle, Fig. II. The 30 per cent, 9 inch cream bottle, Fig. II., is graduated into .2 per cent, while the 50 per cent, 6 inch bottle, Fig. III., is graduated

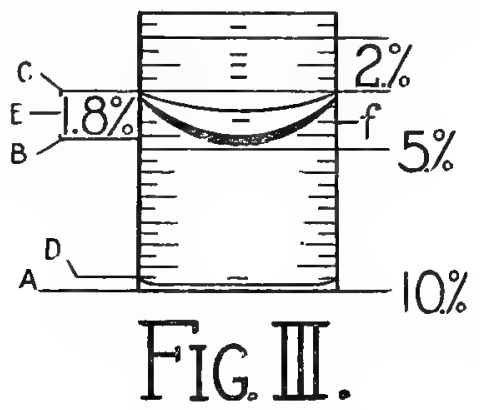

into .5 per cent. The meniscus of the bottle, Fig. III, is about 1.8 per cent. Reading this bottle from the extreme bottom to the extreme top, the reading is about 2 per cent too high, as compared with Fig. II, the reading of which is about .3 per cent too high. 
The difference here is due only to the difference in the graduation of the bottle, the size of neck and the grams used. It will be noticed that the space between the markings on the bottle, Fig. III, are about three times as close as the markings on bottle, Fig. 1I. This closeness of graduations increases errors in reading, by three. The closer the markings of spaces occupying 1 per cent on the reading, the greater are the chances of errors arising through not being able to get a perfectly correct reading. From this analysis it seems that the bottle shown in Fig. III. is the most difficult to read correctly. The safest way to read this bottle is to read from the extreme bottom, a, to the extreme top, c, of the fat column, and subtract on the average about 2 per cent from the reading. 1 . per cent occupies $1 / 18$ inch on the 50 per cent, 6 inch, 9 gram bottle, Fig. III, and 1 . per cent occupies $1 / 6$ inch on the 30 per cent, 9 inch, 18 gram bottle.

81. Comparing a 55 per cent, 9 inch, Fig. IV., 18 gram cream test bottle with a 50 per cent, 6 inch, Fig. III, and a 30 per cent, 9 inch, Fig. II, bottle.

Fig. 1V, 55 per cent, 9 inch, 18 gram cream test bottle is graduated into $1 / 2$ per cent divisions; each division measuring in width $1 / 23$ of an inch. Each $1 / 23$ inch on the neck of the bottle means .5 per ecnt fat. 1 per cent of fat occupies about 1/12 inch space. In bottle shown in Fig. II, 1 per cent occupies $1 / 6$ of an inch space. The per cent spaces, on a 30 per cent, 9 inch cream bottle, Fig. II, are twice as wide as those on the bottle shown in Fig. IV, and at the same time represent the same per cent of fat. Any error 
made in using bottle shown in Fig. IV is twice as great as the same error made when using bottle shown in Fig. II. An error made in using bottle shown in Fig. III is $1 \frac{1}{2}$ times as great as the same error made in using bottle shown in Fig. IV.

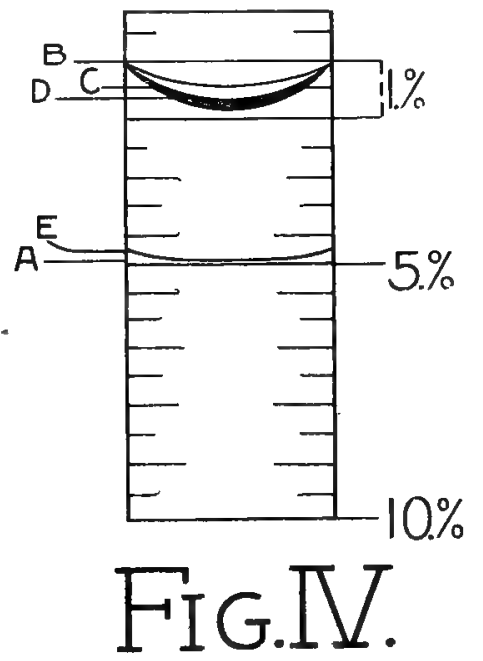

These errors used for illustration may be due to either over or under reading, caused by an oversight, slipping of the dividers, or any foreign substance which may have found its way unnoticed into the fat column.

The meniscus in Fig. IV occupies about .8 per cent on the reading and in extreme cases 1 per cent. Including the curvature at the bottom, the reading between the extreme ends of the fat column, $a-b$, is .8 per cent to 1 per cent too high. For practical purposes, read from a to $b$ and subtract nearly 1 per cent. This will come nearer to the right reading than 
reading from a to $\mathrm{c}$ or from e to $\mathbf{d}$ (and allowing for the meniscus) due to difficulty in locating these places on the graduation. The curvature of the bottom of the column in eream tests is rounded enough to allow for the .2 per cent left in the test bottle. Therefore all subtracting should be done from the top-the space occupied by the meniscus.

82. Comparing a 50 per cent, 6 inch, 18 gram cream test bottle with a. 30 per cent (Fig. II.) a 50 per cent (Fig. III.), and a 55 per cent (Fig. IV.) bottle.

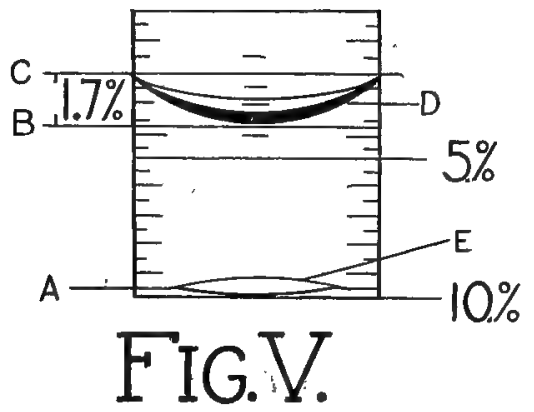

Fig. V shows a 50 per cent cream bottle graduated into 1 per cent. There are 16.3 per cent per inch in the graduation. The graduated part of neck is about $31 / 16$ inch long. The diameter of the inside of neck is $1 / 2$ inch. This is too. wide for correct reading, because the bottom of the fat column is not always even. Sometimes the bottom of the fat column curves upward, or is slightly hollow (e), or irregular. Due to these unavoidable irregularities this bottle should be used in the following manner if it must be used: Read from the extreme bottom 
(a) of the fat column to the bottom of the meniscus (b), or from (a) to half way between (b) and (d). Do not add or subtract anything in practical work. When the bottom of the fat column is smooth and well defined, and the meniscus is clear and well defined, half of the meniscus may be included in the reading (b-d). That is, read from (a) to (d). When the bottom of the fat column is irregular and the meniseus not well defined, read from (a) nearly to (d), between (b) and (d). Since the graduations are divided into whole per cents and the neck is so wide, the bottle is not at all desirable for accurate work.

For convenience in illustrating, the Fig. V. shows graduations in .5 per cent instead of 1 per cent, the way the bottle is actually graduated. Since the cream bottle in Fig. V. is only graduated into 1 per cent, and 1 per cent on this bottle occupies only about $1 / 16$ of an inch, it is plain that a slight error in reading this bottle would make a great difference in the results.

83. Comparing a 30 per cent, 6 inch, 18 gram, cream test bottle with bottles shown in Figs. II., III., IV., V. The 30 per cent, 6 inch, 18 gram bottle, Fig. VI., is graduated in $1 / 2$ per cent and 12 per cent occupies a space of 1 inch. Therefore, .5 per cent occupies $1 / 24$ inch, which is about the same as bottle in Fig. IV. This is a very good bottle, unless cream tests more than 30 per cent when an 18 gram sample must be used.

When the scales are sensitive and the sample well mixed and correctly weighed, it may be advisable to 
weigh less than 18 grams of cream for testing, but for the average creameryman, it is not advisable to weigh out less than 18 grams of eream.

84. Errors arise from weighing out 9 grams (as the result must be multiplied by two) and errors are further incurred by weighing cream on a scale not sensitive enough, where a drop or two too much would raise the test considerably. If 18 grams are used any small error is not multiplied.

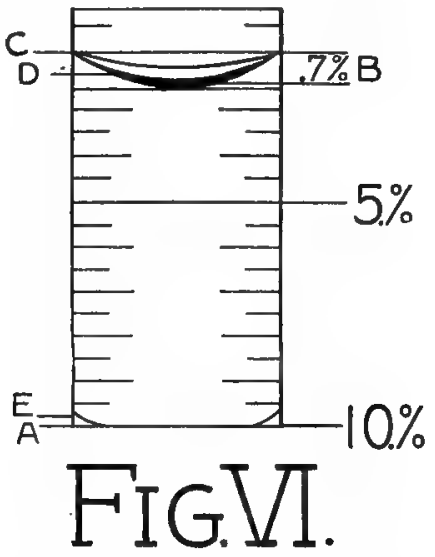

The cream test bottle Fig. VI should be read either from a to $d$ or from e to $c$, or half way between $\mathbf{d}$ and $\mathbf{c}$. The part between $\mathbf{b}$ and $\mathbf{c}$ is the meniscus and occupies about .7 per cent space on the graduations.

85. Comparative length of the graduated part of the neck of cream test bottles.

From the following table as well as from the foregoing discussion it will be seen that the larger the space occupied by 1 per cent on the test bottle, the 
less chance there is for errors. When 1 per cent on the reading. of the test bottle takes up only $1 / 18$ of an inch, and 5 per cent takes up only $5 / 18$ of an jnch, one can readily understand that the chances are greater than with a bottle on which 1 per cent takes up about $1 / 6$ of an inch on the reading of the test bottle, or 5 per cent takes up about $5 / 6$ of an inch, or nearly one inch.

\section{TABLE XIII.}

Comparatice Length of the Grannated Part of the Inck of Cream Test Bottles.

\begin{tabular}{|c|c|c|c|c|c|}
\hline Figures & II & III & IV & $\mathrm{T}^{r}$ & VI \\
\hline $\begin{array}{l}\text { Grams basis on which } \\
\text { bottleg are graduated..... }\end{array}$ & 18 & 9 & 18 & 18 & 18 \\
\hline Per cent cream bottle....... & $30 \%$ & $50 \%$ & $55 \%$ & $50 \%$ & $30 \%$ \\
\hline Size of bottle............................ & 9 in & 6 in & 9 in & 6 in & 6 in \\
\hline Length of graduation........ & $51 / 8$ in & $27 / 8$ in & $413 / 16$ in & 81,16 in & $21 / 2$ in \\
\hline Graduated $\% \ldots . . .$. & $.2 \%$ & $.5 \%$ & $.5 \%$ & $.1 \%$ & $.5 \%$ \\
\hline Number of per cent per inch & $57 / 8 \%$ & $18 \%$ & $11.4 \%$ & $16.3 \%$ & $12 \%$ \\
\hline Inside diameter of neck...... & $\%$ & 2964 in & $25 / 64$ in & $1 / 2$ in & $13 / 32$ in \\
\hline Space meniscus occuples \%... & $.3-.4$ & $\mid 11 / 4-1.8$ & $.7-1$ & $1 .-1.6$ & $.5-.7$ \\
\hline
\end{tabular}

\section{Reading of cream tests.}

We must not forget that in practical work there must be a method for reading tests, which can be quickly as well as accurately performed. In Bulletin No. 58, U. S. Department of Agriculture, we find a short rule to be used to assist in reading cream tests accurately. It-is as follows: "Read the test from the extreme top to bottom of fat column; deduct from this reading four-fifths of the depth of the meniseus and add 2 per cent to the results." This 
rule is short, but the computations necessary may prove too much for the ordinary creamery operator. Since we know that the fat column in all cream test bottles is curved downward at the bottom, enough to cause a hollow on each side of about .1 per cent, we can safely say that the .2 per cent of fat supposed to remain in the bulb of the bottle will be sufficient to fill this space. The fat column in bottle Fig. II., 30 per cent, 9 inch eream bottle, is practically straight at the bottom and therefore this would not apply to this particular bottle. Knowing about how much the meniscus of each cream test bottle occupies, and how much more easily the reading of the test from the extreme bottom to the extreme top of the fat column can be done, why not read cream tests in the following manner:

Rule. Read any cream test from the extreme bottom to the extreme top of the meniscus, and subtract from this reading nearly the whole per cent of the meniscus.

\section{Illustrating how to read cream tests.}

The above readings correspond very closely with reading taken from a tod in Fig. VI, a to $d$ in Fig. $V$, a to $f$ in Fig. III, a to $c$ in Fig. IV, and $d$ to $f$ in Fig. II. Inaccurate sampling and weighing of cream samples, as well as incorrect whirling of bottles and reading tests at improper temperatures, are the "ause of as much inaccuracy in testing as may arise from the use of improper cream test bottles. It is, however, very important in testing cream, to have bottles, the graduations of which are not placed 
eloser than 10 to 12 , per cent spaces, per inch of graduation. The bottles that are graduated to carry 6 to 8 , per cent spaces, per inch are much to be preferred.

Illustrating How to Read Cream Tests.

\begin{tabular}{|c|c|c|c|c|}
\hline $\begin{array}{l}\text { Cream } \\
\text { bottle }\end{array}$ & Size & $\begin{array}{c}\text { Full } \\
\text { Reading }\end{array}$ & $\begin{array}{l}\text { A verage } \\
\text { Per cent of } \\
\text { meniscus }\end{array}$ & $\begin{array}{l}\text { Corrected } \\
\text { Reading }\end{array}$ \\
\hline $30 \%$ & $9 \mathrm{in}$. & $30 \%$ & $.3 \%$ & 29.7 \\
\hline $30 \%$ & $6 \mathrm{ins}$ & $30 \%$ & $.5 \%$ & 29.5 \\
\hline $\begin{array}{l}9 \text { gram } \\
50 \%\end{array}$ & $6 \mathrm{in.}$ & $30 \%$ & $1.5 \%$ & 28.5 \\
\hline $55 \%$ & 9 in. & $30 \%$ & $.7 \%$ & 29.2 \\
\hline $50 \%$ & $6 \mathrm{in.}$. & $30 \%$ & $1.2 \%$ & 28.7 \\
\hline
\end{tabular}

88. The most accurate cream test bottles now generally used are the 30 per cent, 18 gram, 6 inch, $3 / 8$ inch neck diameter; the 30 per cent, 18 gram, 9 inch, and the 50-55 per cent, 9 inch, 18 gram cream test bottle.

The reason why the reading of tests made from the same lot of cream with differently graduated cream test bottles is not always the same is mainly due to inaccurate graduation of the bottle, irregularity in the surface of the top and bottom of the fat column and the inability to determine the proper points on the graduation from which to read the tests. Were the fat column clear, with straight top and bottom line, the reading could be accurately done with any cream test bottle. 


\section{CHR. HANSEN'S \\ Danish Dairy Preparations}

INCLUDE

Danish Rennet Extract Danish Cheese Color Danish Butter Color Lactic Ferment Culture

All well known to Butter and Cheese Makers throughout the World and for sale generally by dealers in Dairy Supplies.

For Cheese Making on the Farm, use

Chr. Hansen's Rennet Tablets and Cheese Color Tablets

Highly concentrated and handy to send by mail. For sale by Druggists.

Dairymen making ICE CREAM will do well to try our VANILLA and other FLAVORING EXTRAGTS as well as our JUNKET COLORS. The Junket Process for Ice Cream saves expense and makes a most delicious product,

CHR. HANSEN'S LABORATORY LITTLE FALLS, N. Y. 


\section{Postal Dairy Library.}

THIS form of Extension Library was estabblished at the Dairy School at Madison, Wis., in response to frequent request for loans of bulletins, books, etc.

The Library consists of over 1,000 different articles, nearly all relating to dairying and kindred subjects which were gathered from all parts of the United States and Canada. Most of them are in the shape of bulletins and circulars from the various Experiment Stations. Many addresses given before Buttermaker's, Cheesemaker's and Dairymen's conventions are also included in this collection. These bulletins, circulars, etc., are loaned upon request for a period of three weeks. The Library gets its name from the fact that it makes use of the Postal Service in transporting the publications.

A catalog has been prepared in which all of this material has been classified so that a patron can readily find such publications as he desires. This catalog also gives full directions how the service of the Library may be obtained, and is mailed free of charge to persons requesting the same.

Buttermakers, cheesemakers, dairymen, teachers, etc., are earnestly requested to make full use of this new form of extension work.

Postal Dairy Library

Madison, Wis. 


\section{H. BURRELL \& COMPANY LITTLE FALLS, N. Y.}

Manufacturers of the Most Complete and Up-to-date Line of Specialties for the Handling of Milk in Any Quantity, and for the Manufacture of Butter and Cheese.

\section{The "SIMPLEX" Line of Dairy Specialties}

Link Blade Cream Separators.

Combined Churns and Butter Workers.

Cream Ripeners.

Internal Tube System of Pasteurizing and Cooling Milk.

Sanitary Tubular Coolers.

"Facile" Babcock Milk Testers.

“B. \& W." Double Surface Milk Heaters, and Check Pumps.

"Lapham" Brand Seamless Cheese Bandage. Cheese Presses. Cheese Vats, Etc.

Chr. Hansen's Celebrated Danish Dairy Preparations.

We are also Manufacturers of the Burrell-LawrenceKennedy Milking Machines, and will gladly send copy of catalogue telling of the advantages of machine milking, and information regarding the production of certified milk.

D. H. BURRELL \& COMPANY LITTLE FALLS, N. Y. 


\section{The Wizard Will Do It All}

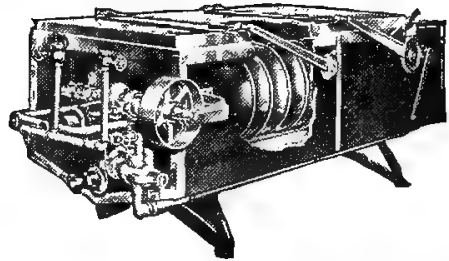

The Wizard Agitator is a pasteurizer, a cooler, an emulsifier, a ripener.

In it the cream can be pasteurized, aerated, cooled, the starter emulsified in, the mixture ripened and the butterfat hardened to the proper degree for exhaustive churning and perfect body.

And no one machine or combination of machines will do the work, or any part of it, better.

The secret? It is constructed on the right principle - that of the spiral disc coil.

As an emulsifier, this coil agitates and mixes the cream without churning it, which is not possible with other coils. The Wizard is the only emulsifying ripener.

As a pasteurizer, the coil heats or cools the cream quickly, and the temperature is the same in all parts of the vat. The pasteurization is thorough.

Complete information and prices will be given on request.

\section{The C. P. Line is Complete}

We furnish complete equipment and supplies for Creameries, Cheese Factories, Farm Dairies, Produce Dealers, Ice Cream Makers. Ice Making and Refrigerating Machinery in all capacities and for every purpose. Catalogs free.

\section{The Greamery Package Mfg. Company Chicago, III., U. S. A.}

Albany, N. Y. Pbiladelphia, Pa. Minneapolis, Mino. Toledo, $\mathbf{O}$. Kansas City, Mo. Waterloo, Ia.

Omaha, Neb. 











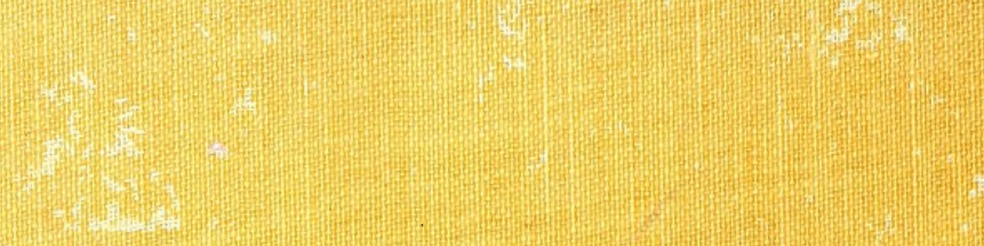